Florida International University FIU Digital Commons

4-20-2011

\title{
A Youth Vision of the City: The Socio-Spatial Lives and Exclusion of Street Girls in Bogota, Colombia
}

Amy E. Ritterbusch

Florida International University, amy.ritterbusch@gmail.com

DOI: $10.25148 /$ etd.FI1 1072511

Follow this and additional works at: https://digitalcommons.fiu.edu/etd

\section{Recommended Citation}

Ritterbusch, Amy E., "A Youth Vision of the City: The Socio-Spatial Lives and Exclusion of Street Girls in Bogota, Colombia" (2011). FIU Electronic Theses and Dissertations. 432.

https://digitalcommons.fiu.edu/etd/432 


\title{
FLORIDA INTERNATIONAL UNIVERSITY
}

Miami, Florida

\section{A YOUTH VISION OF THE CITY: THE SOCIO-SPATIAL LIVES AND EXCLUSION OF STREET GIRLS IN BOGOTA, COLOMBIA}

\author{
A dissertation submitted in partial fulfillment of the \\ requirements for the degree of \\ DOCTOR OF PHILOSOPHY \\ in \\ INTERNATIONAL RELATIONS \\ by
}

Amy E. Ritterbusch

2011 


\section{To: $\quad$ Dean Kenneth Furton}

College of Arts and Sciences

This dissertation, written by Amy E. Ritterbusch, and entitled A Youth Vision of the City: The Socio-Spatial Lives and Exclusion of Street Girls in Bogota, Colombia, having been approved in respect to style and intellectual content, is referred to you for judgement.

We have read this dissertation and recommend that it be approved.

Christopher Lukinbeal

Bianca Premo

Richard Tardanico

Patricia Price, Major Professor

Date of Defense: April 20, 2011

The dissertation of Amy E. Ritterbusch is approved.

Dean Kenneth Furton
College of Arts and Sciences

Florida International University, 2011 


\section{DEDICATION}

I dedicate my dissertation to the street girls that made this dissertation research possible and to all my family members and closest friends that supported me along the way. 


\section{ACKNOWLEDGMENTS}

I wish to thank the members of my committee for their support and guidance throughout the dissertation research and writing process. Dr. Patricia Price was the driving force behind my doctoral training and guidance throughout fieldwork in Latin America and I have learned so much from her mentorship. I wish to thank my parents, Virginia and Stanley Ritterbusch, and partner, Hover Riascos Alomia, for believing in me and providing their loving support as I entered the world of street girls. Stephanie Brown, Richard Gioioso, Hannah Coleman and Diana Riascos Valencia also stood by me throughout the research and writing process and I am extremely grateful for this emotional support. I also wish to thank the Fenix Foundation, especially Timothy Ross and Paola Ceballos, for accepting me as part of the Fenix family of outreach workers and introducing me to the streets. Most importantly, I wish to thank each girl involved in the project for showing me the way, accepting me within the community, befriending me and taking care of me in the roughest streets.

Funding for this research was granted by the Florida International University Doctoral Evidence Acquisition Fellowship, the National Science Foundation Doctoral Dissertation Research Improvement Grant, the Fulbright U.S. Student Program, and the American Association of University Women Dissertation Fellowship. Any opinions expressed in this dissertation are those of the author and do not represent the views of any of the funding agencies or institutions. 


\section{ABSTRACT OF THE DISSERTATION \\ A YOUTH VISION OF THE CITY: THE SOCIO-SPATIAL LIVES AND EXCLUSION OF STREET GIRLS IN BOGOTA, COLOMBIA}

by

Amy E. Ritterbusch

Florida International University, 2011

Miami, Florida

\section{Professor Patricia Price, Major Professor}

This dissertation documents the everyday lives and spaces of a population of youth typically constructed as out of place, and the broader urban context in which they are rendered as such. Thirty-three female and transgender street youth participated in the development of this youth-based participatory action research (YPAR) project utilizing geo-ethnographic methods, auto-photography, and archival research throughout a sixphase, eighteen-month research process in Bogotá, Colombia.

This dissertation details the participatory writing process that enabled the YPAR research team to destabilize dominant representations of both street girls and urban space and the participatory mapping process that enabled the development of a youth vision of the city through cartographic images. The maps display individual and aggregate spatial data indicating trends within and making comparisons between three subgroups of the research population according to nine spatial variables. These spatial data, coupled with photographic and ethnographic data, substantiate that street girls' mobilities and activity spaces intersect with and are altered by state-sponsored urban renewal projects and 
paramilitary-led social cleansing killings, both efforts to clean up Bogotá by purging the city center of deviant populations and places.

Advancing an ethical approach to conducting research with excluded populations, this dissertation argues for the enactment of critical field praxis and care ethics within a YPAR framework to incorporate young people as principal research actors rather than merely voices represented in adultist academic discourse. Interjection of considerations of space, gender, and participation into the study of street youth produce new ways of envisioning the city and the role of young people in research. Instead of seeing the city from a panoptic view, Bogotá is revealed through the eyes of street youth who participated in the construction and feminist visualization of a new cartography and counter-map of the city grounded in embodied, situated praxis. This dissertation presents a socially responsible approach to conducting action-research with high-risk youth by documenting how street girls reclaim their right to the city on paper and in practice; through maps of their everyday exclusion in Bogotá followed by activism to fight against it. 


\section{TABLE OF CONTENTS}

CHAPTER

PAGE

I. INTRODUCTION: COLOMBIA THROUGH THE EYES OF STREET

GIRLS. 1

Constructing Youth-based Participatory Action Research............................................

Relevance and Impact of Dissertation Topic ………..............................................6

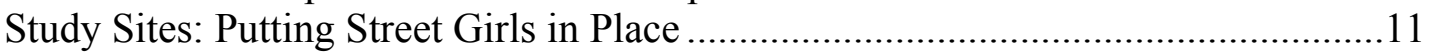

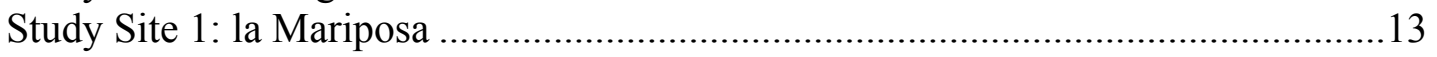

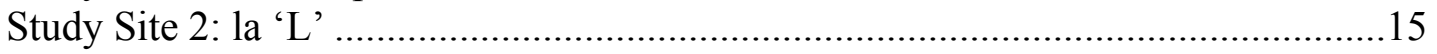

Study Site 3: Las Cruces ................................................................................17

Study Site 4: El Samber.................................................................................19

Study Site 5: Santa Fé (the zone of tolerance) .......................................................23

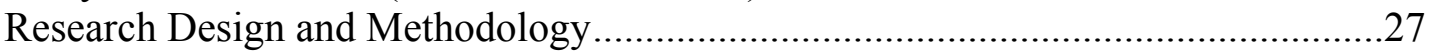

Target Population and Recruitment..................................................................28

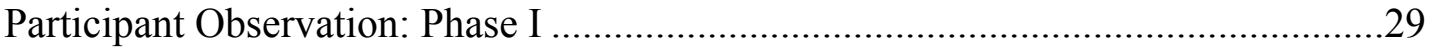

Exploratory Interviews: Phase II .......................................................................29

Auto-photography and Place Perception Interviews: Phase III...................................30

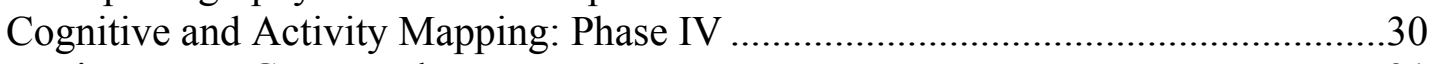

Roving Focus Groups: Phase V.............................................................................

Consultation of Primary and Secondary Sources: Phase VI ......................................32

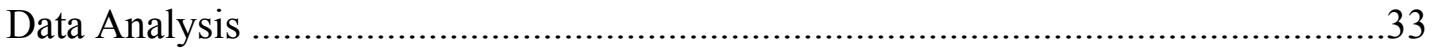

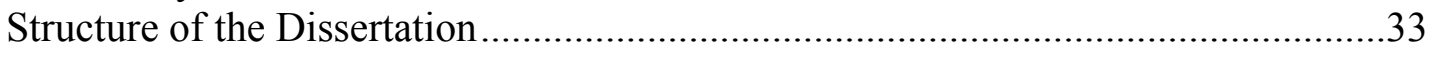

II. RE-FRAMING VIOLENCE IN COLOMBIA: FROM BLIND MONEY TO

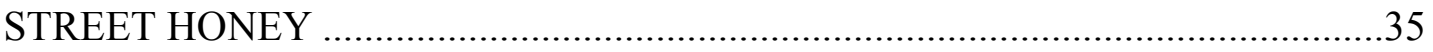

Violence in Colombia and in Street Girls' Lives .......................................................35

Re-framing Violence: Through the Eyes of Street Girls ............................................38

Watching Violence from Above..............................................................................46

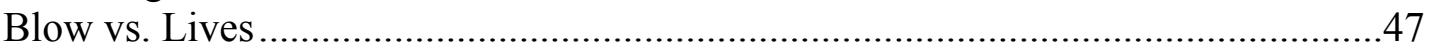

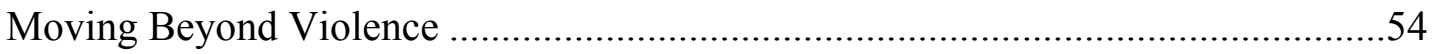

III. YOUNG PEOPLE'S GEOGRAPHIES OF EXCLUSION AND VISION OF

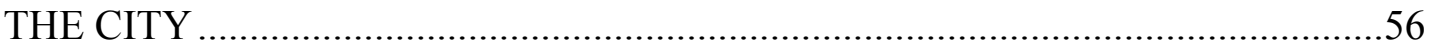

Introduction: From Crisis of Representation to Participation .....................................56

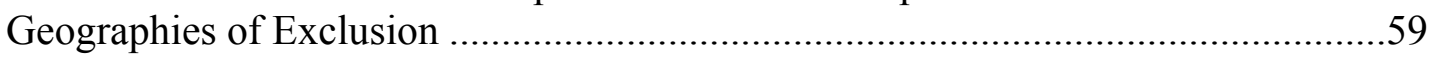

Children's Geographies and Young People as Researchers.......................................68

Grounding Care Ethics in Youth Participatory Action Research................................73

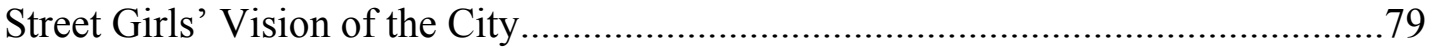

Constructing Counter-maps of Urban Space ............................................................. 82

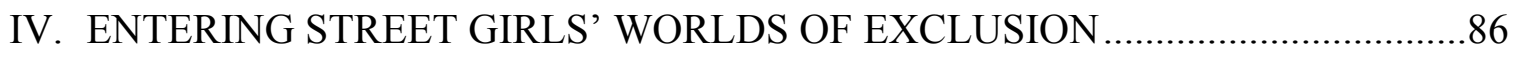

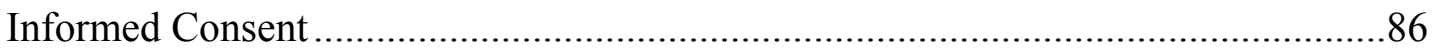

Research Population Subgroups ..............................................................................93

Vulnerable Observation and Intersubjective Knowledge Construction ......................94 
Entering the Field ...............................................................................................96

Vulnerable Observation: Exclusion in the Everyday Life of La Flaca and

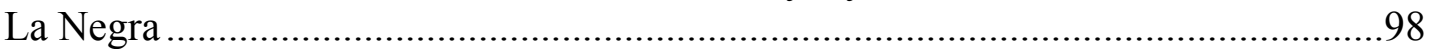

Two Important Field Lessons at Knife Point ........................................................105

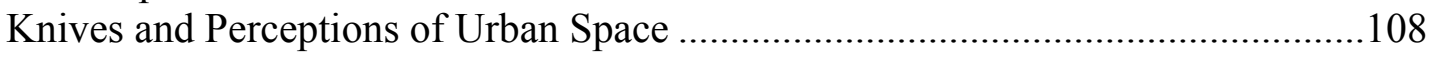

From Stabbing to Caring Relations in the Field ..................................................112

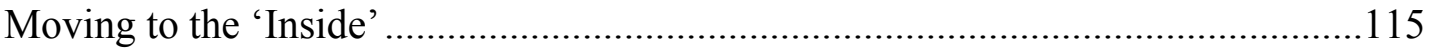

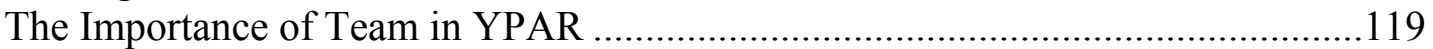

YPAR Team Construction of the Exploratory Interview Guide ..............................121

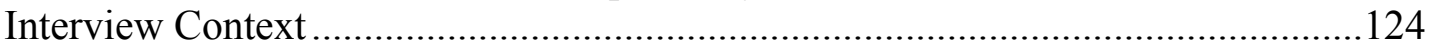

Exclusion and Consumption in Exploratory Interviews.........................................126

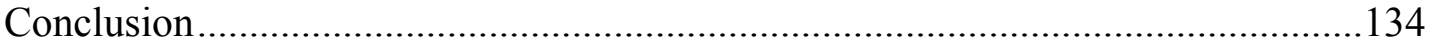

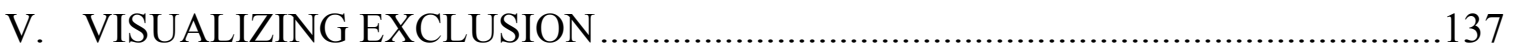

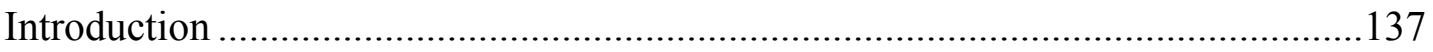

Construction of Participatory Mapping Methods ...................................................139

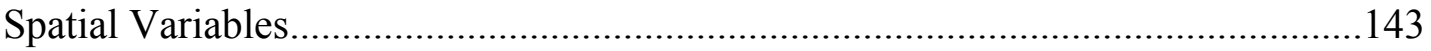

Mapping to Visualize Meaning ............................................................................146

Construction of the Spatial Database, Data Entry and Processing ............................150

Visualizing Social and Spatial Exclusion - Eliminating People and Places

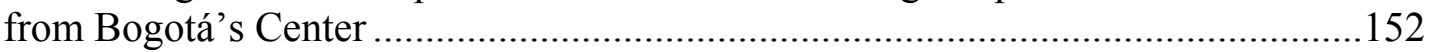

La 'L': From El Cartucho to El Parque Tercer Milenio.............................................155

Smoothing Over Barrios: What Lies Between El Samber and Las Cruces...............176

Putting the 'ACTION' in YPAR: Re-claiming Urban Space....................................183

From la Mariposa to 'San Victorino Centro Internacional de Comercio

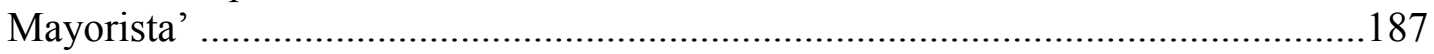

Trans (Im)mobility: My life in Three Blocks and a Cemetery ................................198

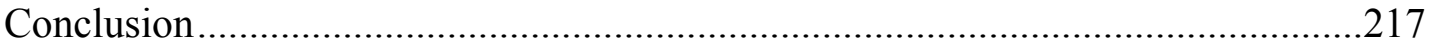

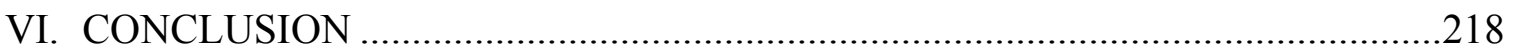

Mobilizing the Voices and Vision of Street Girls ………....................................219

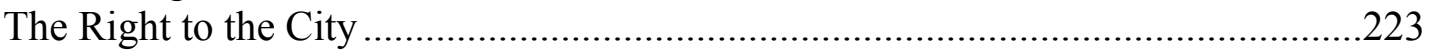

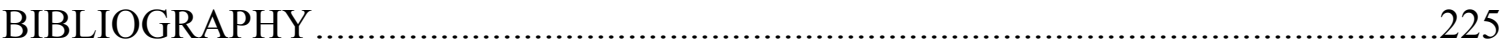

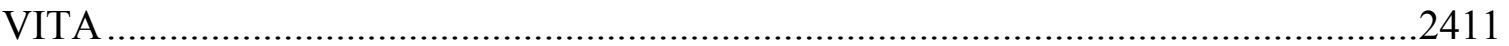




\section{LIST OF MAPS}

MAP

PAGE

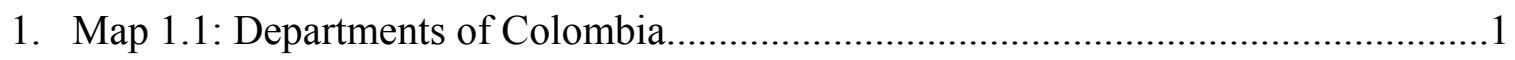

2. Map 1.2: Central Bogotá and Study Sites.............................................................12

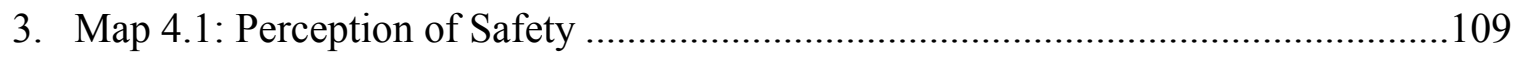

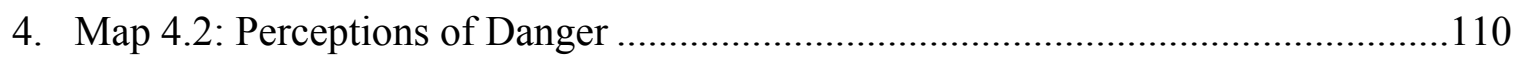

5. Map 4.3: Perceptions of Danger ......................................................................111

6. Map 4.4: Perceptions of Exclusion and Danger.........................................................112

7. Map 5.1: Visualizing Meaning through Maps .........................................................147

8. Map 5.2: Urban Renewal and Geographies of Exclusion...........................................152

9. Map 5.3: Urban Renewal and Activity Spaces .......................................................154

10. Map 5.4: La 'L' - From El Cartucho to El Parque Tercer Milenio..............................155

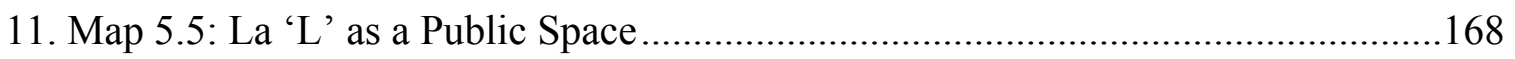

12. Map 5.6: La 'L' - Other Perceptions of Public Space................................................169

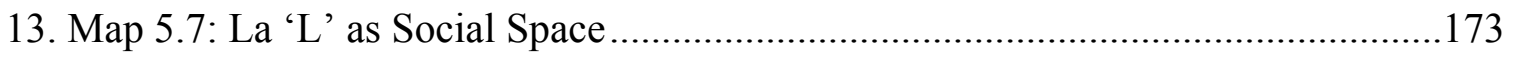

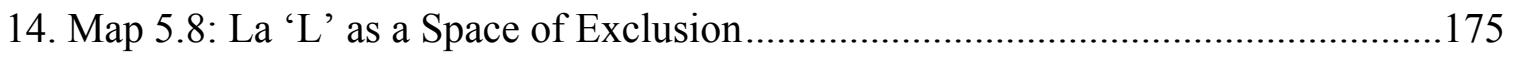

15. Map 5.9: Urban Renewal in El Samber and Las Cruces...........................................176

16. Map 5.10: La Mariposa - Activity Spaces and Urban Renewal.................................187

17. Map 5.11: La Mariposa as a Central Space …………………………………….......191

18. Map 5.12: Multiple Meanings of la Mariposa ……………………….....................193

19. Map 5.13: Santa Fé Activity Spaces - Transgender Subgroup ..................................201

20. Map 5.14: Trans-Life 'Locked' in Three Blocks.....................................................202

21. Map 5.15: Spatial Representations of 'Work' .........................................................205

22. Map 5.16: Perceptions of Safety and Danger in Santa Fé .........................................207 
23. Map 5.17: Perceptions of Danger in the 'Zona Trans' .........................................208

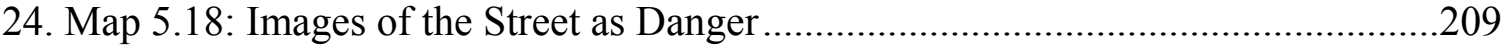

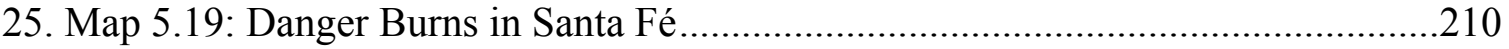

26. Map 5.20: Perceptions of Home and Exclusion in Santa Fé....................................212

27. Map 5.21: Perceptions of Home in the 'Zona Trans' ............................................214

28. Map 5.22: Transgender Subgroup - Urban Journeys through Central Bogotá..........215

29. Map 5.23: Transgender Subgroup - Urban Journeys to Chapinero.........................216 


\section{LIST OF PHOTOGRAPHS}

PHOTOGRAPH

PAGE

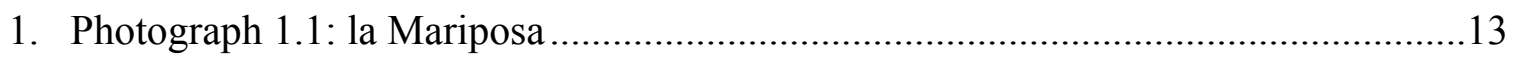

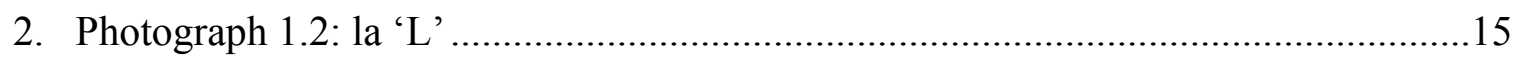

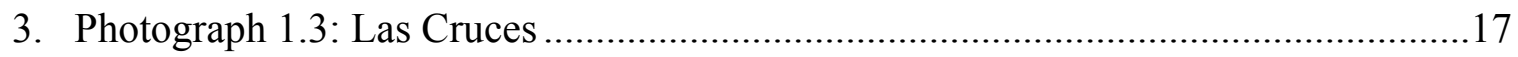

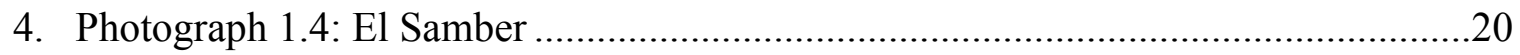

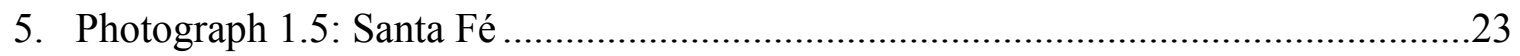

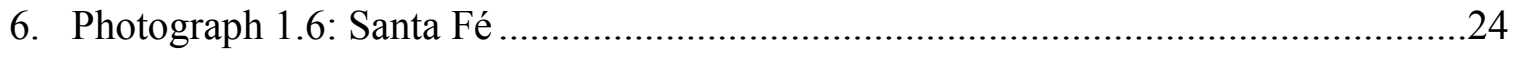

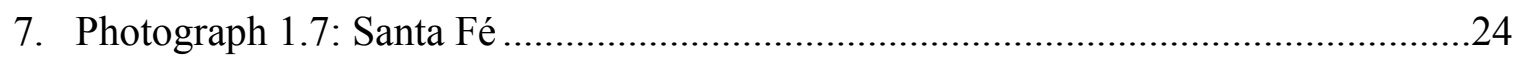

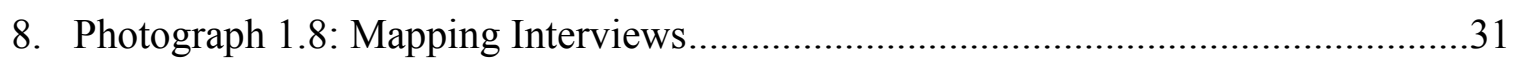

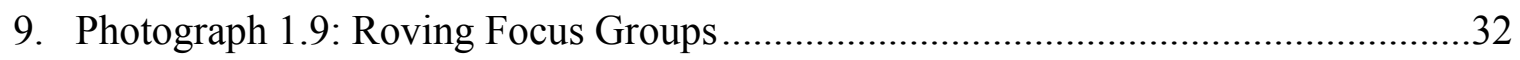

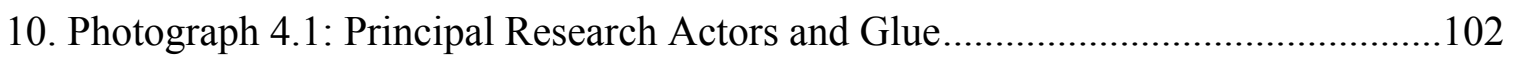

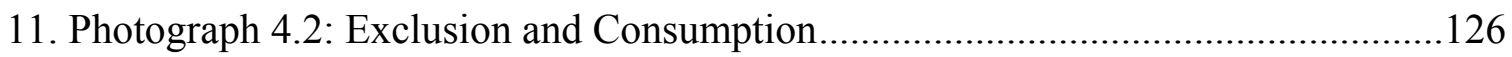

12. Photograph 5.1: El Parque Tercer Milenio - Swings ...........................................161

13. Photograph 5.2: El Parque Tercer Milenio .......................................................... 161

14. Photograph 5.3: El Parque Tercer Milenio - Towards la 'L' ................................... 162

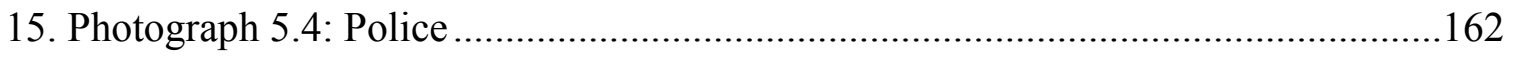

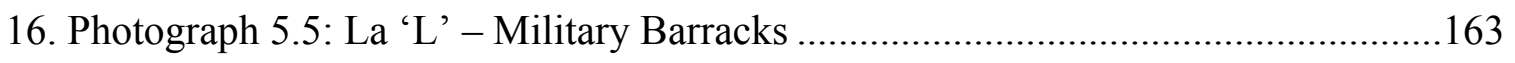

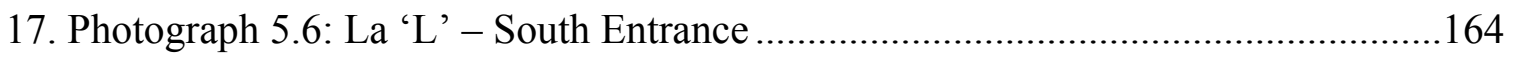

18. Photograph 5.7: YPAR Roving Focus Group..................................................... 166

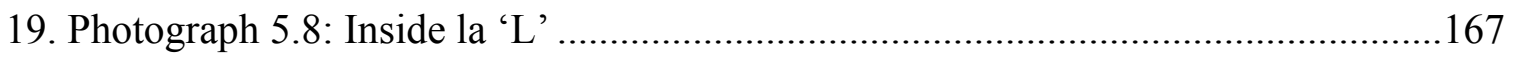

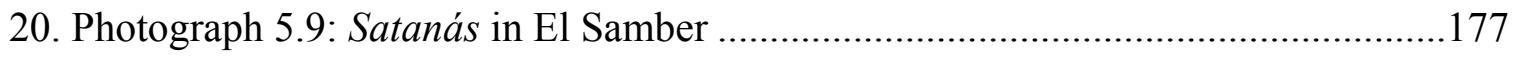

21. Photograph 5.10: Satanás in the Streets of El Samber .......................................178

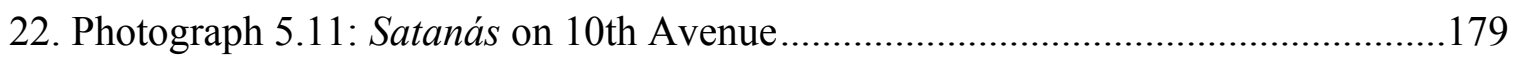


23. Photograph 5.12: Urban Improvement Slogan .......................................................181

24. Photograph 5.13: Hip-Hop for Change - Action Research Presentation.....................185

25. Photograph 5.14: Re-claiming Las Cruces ...............................................................186

26. Photograph 5.15: The Spectacle of la Mariposa .......................................................189

27. Photograph 5.16: La Mariposa and Authorities ......................................................190

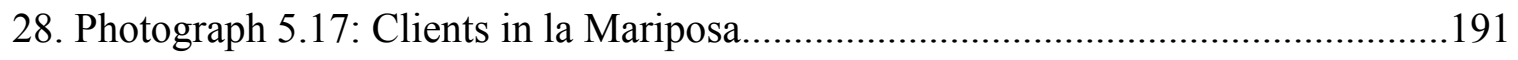

29. Photograph 5.18: La Mariposa Before Urban Renewal.............................................194

30. Photograph 5.19: La Mariposa Before Urban Renewal.............................................195

31. Photograph 5.20: La Mariposa Before Urban Renewal............................................195

32. Photograph 5.21: La Mariposa Before Urban Renewal............................................196

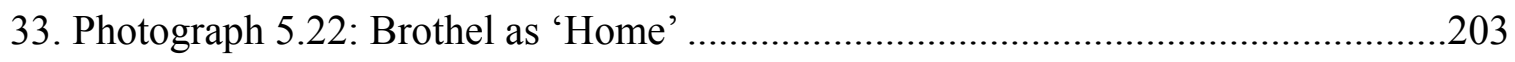

34. Photograph 5.23: Only Safe Behind Locked Doors....................................................204

35. Photograph 5.24: More than Sex Work …………………………………….......206

36. Photograph 5.25: Bambi at 'Home' .................................................................213

37. Photograph 5.26: LGBT Bar and 'Home' Space ....................................................213 


\section{LIST OF FIGURES}

FIGURE

PAGE

1. Figure 2.1: Textual Representation of Violence ............................................... 45

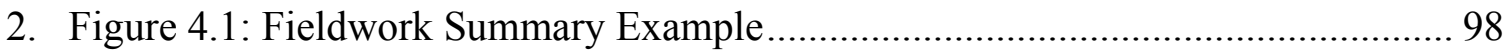

3. Figure 5.1: Base Map Construction - Preliminary Sketch Map ............................. 142

4. Figure 5.2: Spatial Questionairre Example...................................................... 143

5. Figure 5.3: Project Planning Image ............................................................... 182

6. Figure 5.4: Project Planning Image - la Mariposa ............................................. 196

7. Figure 5.5: Re-appropriating Urban Space .................................................... 199

8. Figure 5.6: Social Cleansing Flyer Received by Multiple Research Actors............ 211 
I. Introduction: Colombia through the Eyes of Street Girls

Map 1.1: Departments of Colombia

\section{Departments of Colombia}
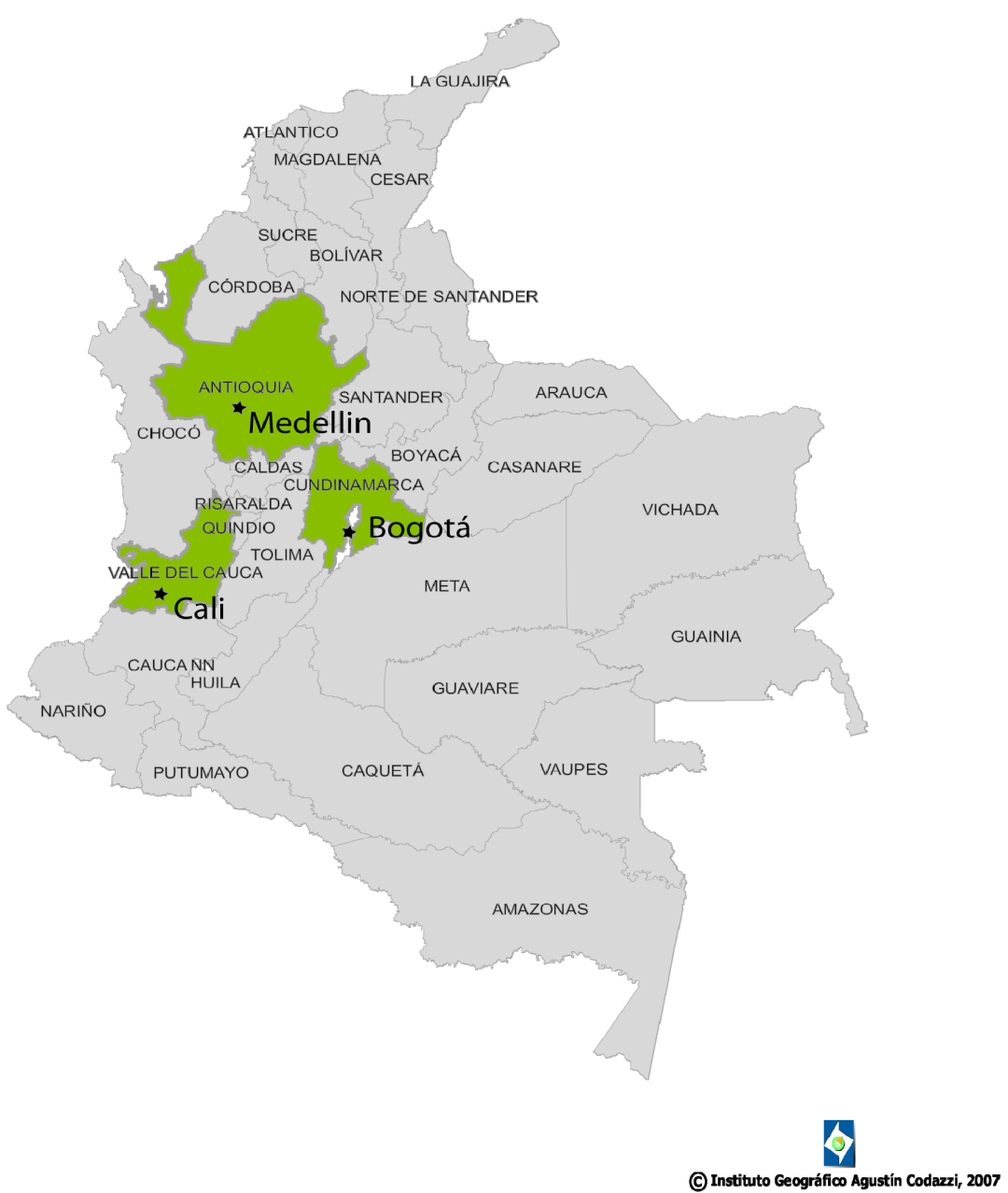

Instituto Geográfico Agustín Codazzi, 2007 Mapa generado automaticamente en la página de internet: http://sigotn. Igac.gov.co/sigotn INFORMACIÓN DE

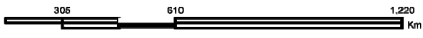

Proyección Conforme de Gauss - Origen Bogotá Dátum MAGNA - SIRGAS Coordenadas Geograificas $4^{\circ} 35^{\prime} 46^{\prime \prime} .3215$ Lat.N.- $74^{\circ} 04^{\prime} 39^{\prime \prime} .0285$ Long. W. Coordenadas Planas $1^{\prime} 000.000$ metros Norte - $1^{\prime} 000.000$ metros Este Fronteras maritimas y terrestres 2007 
'Viaje en Flota' por Blue ('Bus Trip' by Blue)

Al principio estaba preocupada porque estaban murmurando detras mio...y al la vez tranquila porque fui a la casa del man ...empece a preocuparme cuando llegó una lancha y cuando llegó el ejercito...llegaron donde estabamos...un camion del ejercito...dijeron que eran raspachines, donde raspan coca, nos dijeron que ibamos a trabajar haciendo ratos con los manes que trabajan alli...(At first I was worried because they were whispering behind me... and at the same time calm because I had been to the man's house...I started worrying when the boat arrived and when the military arrived...they came to where we were .... a military truck...they said that they were raspachines (laborers, many times children, who pick the coca leaf from the plant), where they raspan (pick/strip) coca, they told us we were going to turn tricks with the men who work there...) (Blue, Participatory Writing Workshop, October 16, 2010).

Hola, mi nombre es Blue. Quisiera contar una historia q'me sucedio pues hace dos años entré en el trabajo de la prostitucion y tenia una amiga q' habia trabajado en el Guaviare y me propuso que fuera a trabajar aya que me pagaban super bien y q llebara tres amigas mas q'aya solo habian raspachines. Yo solo fuy con una amiga nos presentaron a un viejito q' vivia en Santa Librada nos acompañaron a cojer un bus y nos dieron a cada una $\$ 100,000$ [pesos colombianos] y nos dejaron en el terminal con dos manes q' eran los q' nos ivan acompañar a la finca, Pero ellos primero nos djieron que ivamos para Villao [Villavivencio, Meta] y cuando estabamos en el bus nos dijeron q era para el Guaviare. Llegamos al Guaviare nos llevaron a un hotel para que nos cambiaramos y nos bañaramos ellos nos esperaron en una tienda nosotras salimos y nos tomamos de a dos cervezas cuando llego un señor con una lancha y dijo q' esa lancha era para pasar un rio mi amiga se asusto y llamo al ejercito y nos isieron una preguntas y nos separaron nos tenian vijiladas, a los dos dias nos mandaron en avioneta para Bogotá y a mi me internaron por ser

\footnotetext{
${ }^{1}$ Translation note: The translation process when writing ethnography and translating ethnographic information is central in the representation of participants' voices especially when working with a population of youth whose writing and grammar in Spanish represent a politics of resistance (resisting the formal grammatical structure they learned in primary school) and their exclusion from the educational system (in terms of spelling mistakes). The translation process has been difficult in terms of how to represent street girls' voices in English without sanitizing their narratives and smoothing over or eliminating the intonation of street slang.
} 
menor de edad y a la otra muchacha si la dejaron ir y yo me escape del internado y llegue a mi casa. ${ }^{2}$

(Hi, my name is Blue. I would like to tell a story about what happened to me well two years ago I entered into the work of prostitution and had a friend that had worked in Guaviare (a south-central Department of Colombia, known FARC occupation) and proposed that I go to work there that they would pay me very well and that I should bring three more friends - that over there [the destination in Guaviare] there were only raspachines [her tone indicating that in this case there was no danger]. I only went with one friend - they introduced us to an old man that lived in Santa Librada (a sector of Guaviare) - they accompanied us to catch the bus and they gave each of us $\$ 100,000$ Colombian pesos [approximately $\$ 50$ U.S. dollars] and left us at the [bus] terminal with two men that were the ones who were going to accompany us to the farm [no specific location indicated] - but they first told us that we were going to Villao [Villavicencio, Meta] and when we were in the bus they told us that it was [headed] for Guaviare - we arrived in Guaviare - they took us to a hotel so that we could change and shower - they waited for us in a store - we left [the hotel] and we drank two beers - when a man arrived with a boat and said that the boat was to cross the river [most likely the Guayabero or Guaviare rivers, which demarcate the northern border of the Department] - my friend got scared and called the military and they asked us some questions and they separated us - they watched us closely - two days later, they sent us in a plane to Bogotá and they admitted me to an institution [El Refugio - a local branch of YMCA International for sexually exploited minors] because I was underage and the other girl, yes they let her go, and I escaped from the institution and arrived at my house (Blue, Participatory Writing Workshop, October 16, 2010).

'Rescatando a mi mujer' por Biscocho ('Rescuing my woman' by Biscocho)

Hola mi nombre es Biscocho y me gustaria compartirles una historia de mi vida...centimental y personal...fue aproximadamente [hace] 2 años...mi pareja...mujer y yo viviamos enredadas en el mundo de la prostitucion - algo que no es nada censiyo - mas ahun saviendo que tu pareja lo tiene que aser. Eramos un grupo de muchachas entre 16 y 18 años...buscando una estavilidad...mejor y de una manera

\footnotetext{
${ }^{2}$ Grammatical and other errors in the original text have been preserved. Throughout this dissertation, grammatical errors have been preserved in the text of all original writing excerpts produced by street girls during our participatory writing workshops. As exploratory interview, mapping interview, place-perception interview and focus group material was transcribed by the researcher, Spanish text appears as grammatically interpreted by the researcher.
} 
aparentemente...facil. Un dia comun y corriente...una señora senos aserco y nos propuso un viaje...con hombres narcotraficantes...para ofreser nuestros cervicios del trabajo de la prostitucion pero nunca nos esplico...que despues de la plata y la posada y la comida que nos ofrecieron nos ivan a matar como lo asen normalmente en el Guaviare. La propuesta...la verdad nos inspiro un poco de desconfiansa...ha 3 muchachas del grupo...pero las otras 2 confiadas entre ellas mi pareja...Blue... asectaron. En ese tiempo... mi relación no estava nada bien ...y mi pareja se fue sin consultarmelo...la verdad...yo me entere por una de las compañeras. Como nosotras tenemos un compañero que savia de todos estos casos grasias ha dios...los cojieron a ellos...los narcotraficantes...y mi pareja y la otra compañera llegaron ha Bogotá de nuebo sin ningun rasguño...ni problema. ${ }^{3}$ (Hi my name is Biscocho and I'd like to share with you a story about my life...sentimental and personal...it was approximately two years [ago]...my partner...my woman and I were wrapped up in the world of prostitution - something that is nothing simple - especially knowing that your partner has to do it. We were a group of girls between the age of 16 and 18 years [old]. Looking for stability...greater [stability] and in an apparently...easy way. One normal day... a woman approached us and proposed a trip... with men who run drugs...to offer our services in the work of prostitution but she never explained...that after the money and the hotel and the food that they offered us they were going to kill us like they normally do in Guaviare. Three of us were mistrustful of the offer but the other two - among them my partner...Blue - trustingly accepted [word choice altered from original to more accurately represent narrative meaning]. In that time...my relationship was nothing good... and my partner went without consulting me... actually...I found out through one of our girls. Since we have a friend who knows about all these cases [related to human trafficking, military and the FARC] thank god...they [the military] caught them...the drug traffickers... and my partner and our other girl arrived in Bogotá again without a scratch... without a problem) (Biscocho, Participatory Writing Workshop, October 16, 2010).

Blue and Biscocho, ${ }^{4}$ both introduced to Bogotá's network of sex work and street life at a young age, are a couple and have spent the better portion of their lives together in the streets of the south (Ciudad Bolívar) and center of Bogotá. Though Blue and Biscocho's

\footnotetext{
${ }^{3}$ Grammatical and other errors in the original text have been preserved.

${ }^{4}$ Blue and Biscocho are the pseudonyms chosen by two principal research actors of the YPAR team to protect their identity in both participatory writing workshop excerpts and other original text included throughout the dissertation.
} 
story constitutes a gripping tale of terror that on its own is compelling, it also provides an encapsulation of the multi-dimensional lives of the street girls that are the focus of this dissertation. It illustrates the nuances wrapped up in terms such as guerilla, secuestro (kidnapping), human trafficking, and victimization and simultaneously places the research context and actors within the broader milieu of conflict, war, and narcotrafficking that characterize the popular conception of Colombia in the international community. The movement and appropriation of young bodies, such as Blue's, demonstrates that the lives of street girls in the center of Bogotá are not merely bound to the local or within fixed spaces in the city. Rather, street girls' everyday lives and geographies are dynamic sites where multi-scalar and multi-sited processes of change, difference, exclusion, and violence can be understood without essentializing or sanitizing the issues or spaces (Aitken et al. 2006, 366; Massey 1998; Katz 2004; Massey 2005). The overarching purpose of this dissertation lies in an effort to destabilize the popular representation of Colombia as synonymous with war and drugs, and introduce new actors and significant social dilemmas that are silenced by the focus on the conflict and narcotrafficking.

\section{Constructing Youth-based Participatory Action Research}

This doctoral dissertation research investigates the everyday lives and spaces of a population of youth typically constructed as out of place, and the broader urban context in which they are rendered as such. The development of this youth-based participatory action research (YPAR) project was made possible by the participation of thirty female street youth and their collaboration and leadership throughout the six-phase, eighteen- 
month research process utilizing geo-ethnographic methods, auto-photography, and archival research to represent their everyday social and spatial worlds.

Through the enactment of critical field praxis and care ethics, this doctoral dissertation research works against the disempowering and exclusionary discourses surrounding female youth in Latin American cities by allowing them to speak for themselves vis-à-vis YPAR (Cahill 2007; Lawson 2007). A YPAR approach calls for a research process driven by young people and the construction of research relations based on notions of interconnection, empathy, mutual familiarity, and social responsibility. Therefore, I argue that a YPAR approach challenges the separation between researcher and participant and works to level the social field between these dichotomous categorizations that pre-define human relations and hierarchies in the research process. Consequently, research 'subjects' become research actors and take ownership of the project, define its boundaries and design, and work to effect social change in their community and individual realities.

\section{Relevance and Impact of Dissertation Topic}

This doctoral dissertation produces new knowledge in multiple ways. Firstly, this dissertation provides visibility to and carves out a space for a population of urban youth out of place; female street youth who transgress societal expectations about the place and behavior of girls. Interjection of considerations of space, gender, and participation into the study of street youth yielded spatial data that produce new ways of envisioning the city and placing 'the child in the city' (see Ward 1978; Christensen and O'Brien 2003; Cope 2008). Instead of seeing the city from a panoptic or bird's eye view, Bogotá is revealed through the eyes of female street youth who participated in the construction (and 
feminist visualization) of a new cartography and counter-map of the city grounded in embodied, situated praxis. A street youth vision of the city includes not only cartographic representations of street girls' experience of place but also autophotographed images and textual representations constructed by street girls throughout the six research phases. This contribution bridges the subfield of children's geographies, feminist and critical engagements with geographic information systems (GIS), and social cartography by employing methods from, offering new insights to, and creating a dialogue between each body of literature.

In addition to envisioning the city in new ways, this dissertation re-envisions childhood in general, and street youth in particular, by placing street girls as important actors in urban planning and research planning and making street girls visible in institutional, academic, and public spaces where they were previously invisible and voiceless. Furthermore, through the construction of a youth-based participatory action research program, street girls were given a voice without placing them within a role of victimization or stripping them of their agency. Street girls, therefore, reclaim their city on paper and in practice; through maps of their everyday exclusion in Bogotá followed by activism to fight against their exclusion.

Secondly, the spatial and ethnographic data suggest that street girls' everyday geographies and social experiences of exclusion intersect with official and unofficial urban improvement efforts to clean up Bogotá by eliminating the existence of street girls and their spaces. This dissertation provides concrete examples of social and spatial cleansing efforts in Bogotá indicating who is responsible, where this process is taking place in the city, and how it has affected the lives of street girls. These data ground the 
existing literature on geographies of exclusion and normative geographies and place it within a Latin American urban context.

Thirdly, the development of a YPAR program with marginalized, female street youth grounds the discussion of care ethics in a fieldwork context and provides practical suggestions for future researchers in the field. I argue for the enactment of a care ethics practice in fieldwork as a means of bridging the disconnect between institutionally framed ethics and the principles guiding YPAR design. The inclusion of street girls' voices and texts in my dissertation ${ }^{5}$ operationalizes this key element of YPAR through the academic writing process. ${ }^{6}$ Participatory action research does not end with the formal data collection period. Rather, the direct involvement of research actors in the writing process enables them to mobilize their voices, demonstrate their relationship to the data, and weave the complexity of their identities throughout the text.

Fourthly, the combination of ethnographic and cartographic methodological approaches provides entry points to the urban place-world of street girls yielding important findings that advance a new methodological and theoretical approach to understanding and theorizing the current condition of street youth in the developing world. At first glance, we might think of two obvious entry points or tools that social scientists have used for decades to both 'tame' and 'understand' people and places,

\footnotetext{
${ }^{5}$ The participatory writing process is supported by the AAUW Dissertation Fellowship and consists of weekly writing workshops with the research team of street girls in Bogotá. This process includes the use of various forms of expression (i.e., poetry, hip-hop [lyrical construction], narrative construction) to analyze spatial and ethnographic data, photographs and videos from fieldwork, and fieldnotes in a group context.

${ }^{6}$ Participation of the community in the writing process has involved work on my dissertation and work on a multiple authored book chapter on YPAR as a social movement within prostitution street networks in Latin America.
} 
through observation and then careful ordering: mapping, as part of a long term effort at the "...taming of the spatial" (Massey 2005, 106), and ethnography, as part of a long term effort to tame and preserve enclosed units of culture. Both are research praxis that attempt to smooth over and conceptualize space and society as coherent, whole systems. This dissertation will demonstrate the use of cartographic and ethnographic praxis in empowering, participatory ways that enable critical children's geographers interested in the interconnection between young people and urban places in Latin America to enter the place-world of marginalized young people in cities. This dissertation marks the conceptual and methodological entry points that allow us to embark on this journey, through young people's minds, voices and visions of Bogotá, Colombia.

Our first entry point is through ethnography as the methodology designed to enter the life-world of participants and to attain complete immersion within the everyday lives and reality of the 'communities' we have proposed to research. As Behar (1996) points out, the ethnographic research norm of 'participant observation' is an oxymoron - it prompts us to participate in the community of those we study but at the same time tells us to detach ourselves, take copious notes, interpret what we have seen, and then initiate our retreat, all within the ethical structure set forth by institutional standards. This dissertation calls for geographers to move beyond institutionalized ethics and demonstrates how the enactment of care ethics in the field can lead to more truly critical research praxis.

Our second entry point is through the map. As Massey (2005) puts it, maps are “... slices through space...they are selective (as is any form of re-presentation)...through their codes and conventions and their taxonomic and ordering procedures, maps operate 
as a 'technology of power'...maps (current Western-type maps) give the impression that space is a surface... [t]his arena of space is not firm ground on which to stand. In no way is it a surface..." (Massey 2005, 106-107). Maps, and the arena of space they re-present, therefore, are "...always unfinished and open" (Ibid, 107). My dissertation cracks open the dominant cartographic representation of Bogotá, Colombia vis-à-vis a youth vision of the city. It transfers cartographic power to marginalized urban youth, thus operationalizing a bottom-up GIScience ${ }^{7}$ and presenting an alternative to the dominant form of mapping, which “...position[s] the observer, themselves unobserved, outside and above the object of the gaze" (Ibid, 107). My dissertation shows how street girls' cartography re-makes the city by inverting the gaze, from bird's eye to street corner, from adultist to youth, from hetero-masculinist to a multiplex-girl vision. The young people and peer leaders of this YPAR project re-appropriate their city by employing a symbology and method of structuring and envisioning urban space distinct from the tourist map or other official representations of Bogotá. The maps produced from this collaborative research thus give a voice to street girls not only in terms of what they have lived but how and where they envision their future in and the future of their city.

My dissertation demonstrates how the centralization of a youth-centered optic visà-vis geo-ethnography (the combination of the two entry points developed above) reveals important insights about the place-world of female street youth in Latin American cities. This dissertation also demonstrates how youth geographies of exclusion intersect with larger scale urban improvement efforts that eliminate deviant populations from public space in order to portray Bogotá as a mega-city of progress. In chapters four and five,

\footnotetext{
${ }^{7}$ The science of geographic information systems.
} 
this will be demonstrated on various scales, through public images, discourses, and spaces and through multiple data forms.

\section{Study Sites: Putting Street Girls in Place}

Another contribution of this dissertation is the form of participatory writing advanced in this section and throughout the manuscript. Participatory action research should not end along with the formal data collection period. Rather, the writing process should also involve all research actors in order to more accurately and ethically represent their voices. The following study site descriptions incorporate street girls' perspectives captured in fieldnotes, interviews, roving focus group videos, and research context narratives prepared by individual members of the YPAR team that presented on May 26, 2010 during a seminar at Universidad de los Andes (University of the Andes).

The five study sites were selected by the YPAR team and are located in two central localidades (districts) of Bogotá (Santa Fé and Los Mártires) spanning between $1^{\text {st }}$ Street of Las Cruces (study site 3) and $24^{\text {th }}$ Street of Santa Fé (study site 5) and $17^{\text {th }}$ Avenue of la ' $\mathrm{L}$ ' and Avenue 13A of the sector known as Telecom. Refer to Map 1.2 for the location of each study site in the city center.

\footnotetext{
${ }^{8}$ Study site narratives are based on descriptions prepared by individual members of the YPAR team that presented on May 26, 2010 during a seminar at Universidad de los Andes (CIDER) and other data collected during the six research phases.
} 


\section{Map 1.2: Central Bogotá and Study Sites}

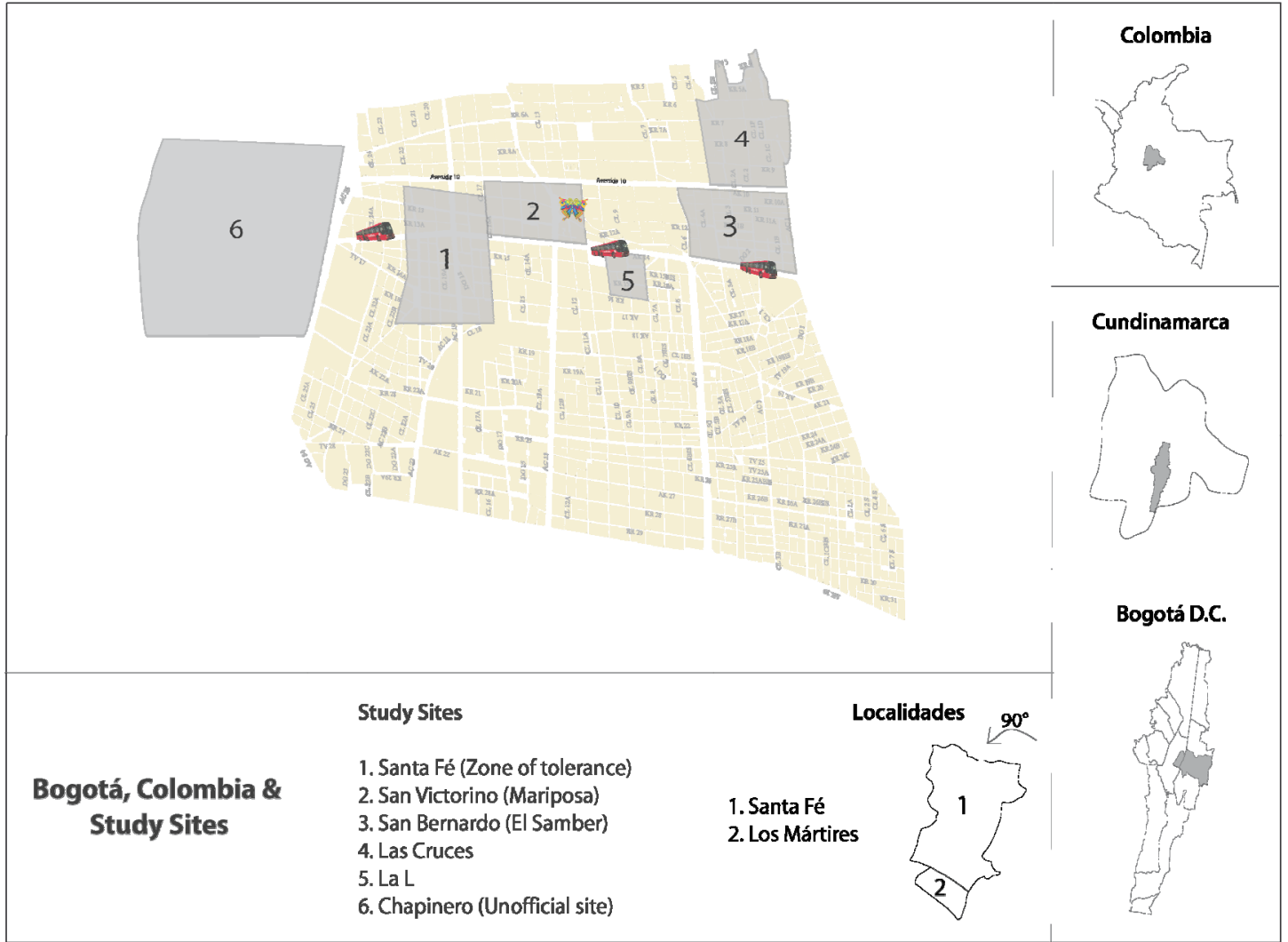


Study Site 1: la Mariposa

Photograph 1.1: la Mariposa

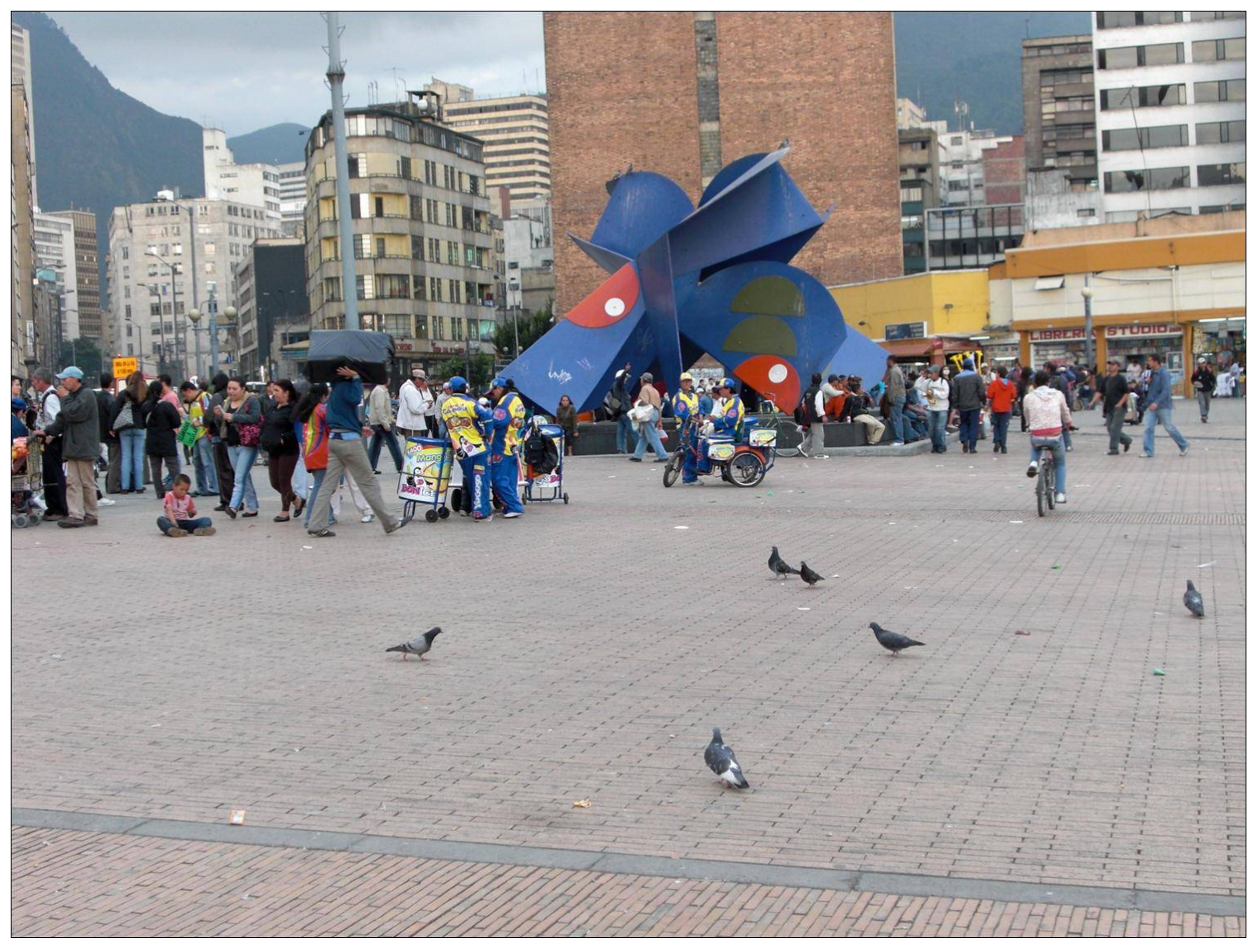

...[E]n este sitio hay de todo...es una zona de comercio, zona de vendedores ambulantes, de drogadicción, de prostitución, de transporte, hay policia...la policia negocia con los ladrones (lo que se roban), les pegan a los vendedores y les piden a las trabajadoras sexuales [un rato] sexo para no internarlas...y personalmente, a mi me pegó una policia cuando estaba en embarazo" (In this place you find everything...it is a commercial zone, a zone of informal street vendors, of drug addiction, of prostitution, of public transportation [Transmilenio], there are police...the police negotiate with thieves (take a share of what they steal), the police 
beat the vendors and they demand sex from sex workers in exchange for not taking them in [to jail or to a child protection agency in the case of minors], and personally, one female police officer beat me [in this place] when I was pregnant) (Blue, YPAR Presentation, May 26, 2010).

As Blue, a YPAR team member, notes in her description of study site one, the Plaza San Victorino, more commonly known to the girls as la Mariposa (the butterfly), la mariputa or la maricosa (both plays on words in Spanish indicating a zone of prostitution) is much more than meets the eye. Besides an outdoor plaza and commercial center, its green patch of grass also serves as a bed for those who have come to seek refuge from la 'L' (a drug zone). El muro (the wall) alongside the green patch is Tato's shoe-shining office. The butterfly sculpture by Edgar Negret, which reflects the spatial meaning of la Mariposa, is the self-vending spot of youth sex workers - where they await clients (rain or shine, police raid or armored riot truck presence) and it's Cristian's ${ }^{9}$ rest spot where he comes to collect money from the girls, rob a passing plaza shopper, hand over a 'pata [d] e cabra, ${ }^{10}$ or take the girls to a lunch of fried street foods. The tree by the Transmilenio bus stop marks la oficina ${ }^{11}$ of the youth lesbian gang - their spot where

\footnotetext{
${ }^{9} \mathrm{He}$ is the lead hustler of la Mariposa and El Samber. El Samber is the abbreviation for barrio San Bernardo, which is another drug dealing/consumption hell hole, one of our study sites, and a sector in the central district of Bogotá be targeted for urban renewal or 'spatial cleansing.'

${ }^{10}$ Pata de cabra - literally translates as goat's foot and refers to the shape of a folding lock knife - both a mugger's tool and the weapon usually carried by the girls in their bra or underwear.

${ }^{11}$ La oficina - 'the office,' amongst many deviant street communities refers to their preferred place of activities.
} 
they await clients while chatting with $E l$ Chocoano $^{12}$ selling cell phone minutes or with $l a$ gorda from Pereira selling cigarettes, candy, coffee, and empanadas. La Mariposa is the place where youth are for sale, where rich clients come from the North of the city, petty businessmen from the wholesale stores around la Mariposa, men from the motorcycle parts dealers in la Panadería (another drug zone six blocks away) - to pick a girl...any girl. Welcome to la Mariposa...the open-air bargain basement for the best deals in used books, street junk food, men's underwear, bad kitchen appliances, and sex with very young girls.

Study Site 2: la ' $L$ '

Photograph 1.2: la 'L'

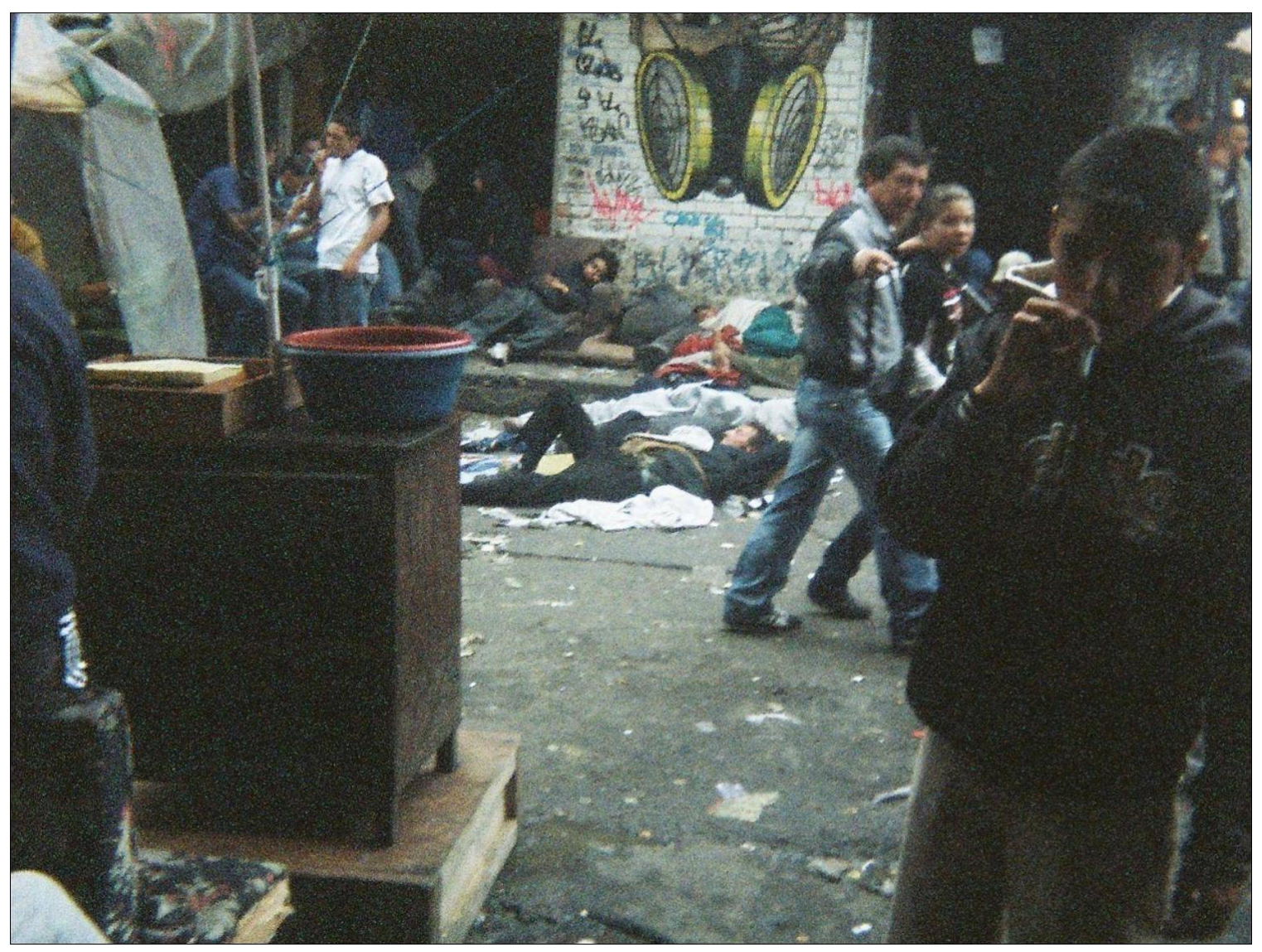

${ }^{12}$ A man from Choco, a Pacific coastal department of Colombia. 
Ahora llegamos a otro lugar...conocido como la 'L' o El Bronx o El

Cartuchito...que es vulnerable y olvidado pero donde tambien hay mucha gente que merece una oportunidad de vida...como la gente que merecian una oportunidad y murieron alli en el Cartucho por no tener una clase social igual a la de Ustedes...(Now we arrive at another place... also known as la 'L' [the 'L'] or El Bronx [the Bronx] or el Cartuchito [Little Cartridge]...that is vulnerable and forgotten but where there are also many people who deserve a chance at life... like the people who deserved a chance and died there in El Cartucho because they didn't have a social class equal to yours...) (El Cilencio and Sentimientos Ocultos,${ }^{13}$ YPAR Presentation, May 24, 2010).

Winding through the web of wholesale stores surrounding la Mariposa and crossing Caracas Avenue (a main central route of the Transmilenio) we come to la 'L,' also known amongst the girls as el Bronx (what remains of El Cartucho, the most dangerous drug zone in Bogotá's history, which was eliminated and replaced by El Parque Tercer Milenio [Third Millennium Park] - see chapter five) located, ironically, behind the national military barracks with full suited guards in fatigues and armed with rifles and next to a Catholic church. La 'L,' its name based on the spatial quality of the main streets of the zone forming an 'L' shape, is the most concentrated and dangerous olla (drug zone

${ }^{13}$ El Cilencio que Quiere a Gritos Decir la Verdad (The Silence who wants to Shout the Truth) and Sentimientos Ocultos (Hidden Feelings) are the pseudonyms chosen by two principal research actors of the YPAR team to protect their identity in both participatory writing workshop excerpts and other original text included throughout the dissertation. Grammatical and spelling errors were preserved. El Cilencio will be used to in the remainder of the text to refer to the first research actor. 
- in street slang) in Bogotá...where youth sex work holds a different meaning entirely...a polvo (screw) for mil pesos or a hit of bazuco ('base' or unrefined cocaine) ...where $L a$ Flaca, a former member of the YPAR team, permanently disappeared into the depths of Homero (one of the rockolas [juke joints] where drugs are sold as in a fresh produce market)...however, this product is not so fresh and, according to urban (street girl) legend, is also mixed with the ashes of bones of those who didn't make it...la ' $\mathrm{L}$ ' is where Mata's brother often stands next to the graffiti of an oxygen mask and smokes bazuco...it is where babies are born and tossed in the dumpster with the batch of other people who didn't make it out in time... it is often where the YPAR team sat on the outdoor couches in the bareques (shacks with couches where people sit and consume) and talked with the corner's jivaro (drug dealer)...

Study Site 3: Las Cruces

\section{Photograph 1.3: Las Cruces}

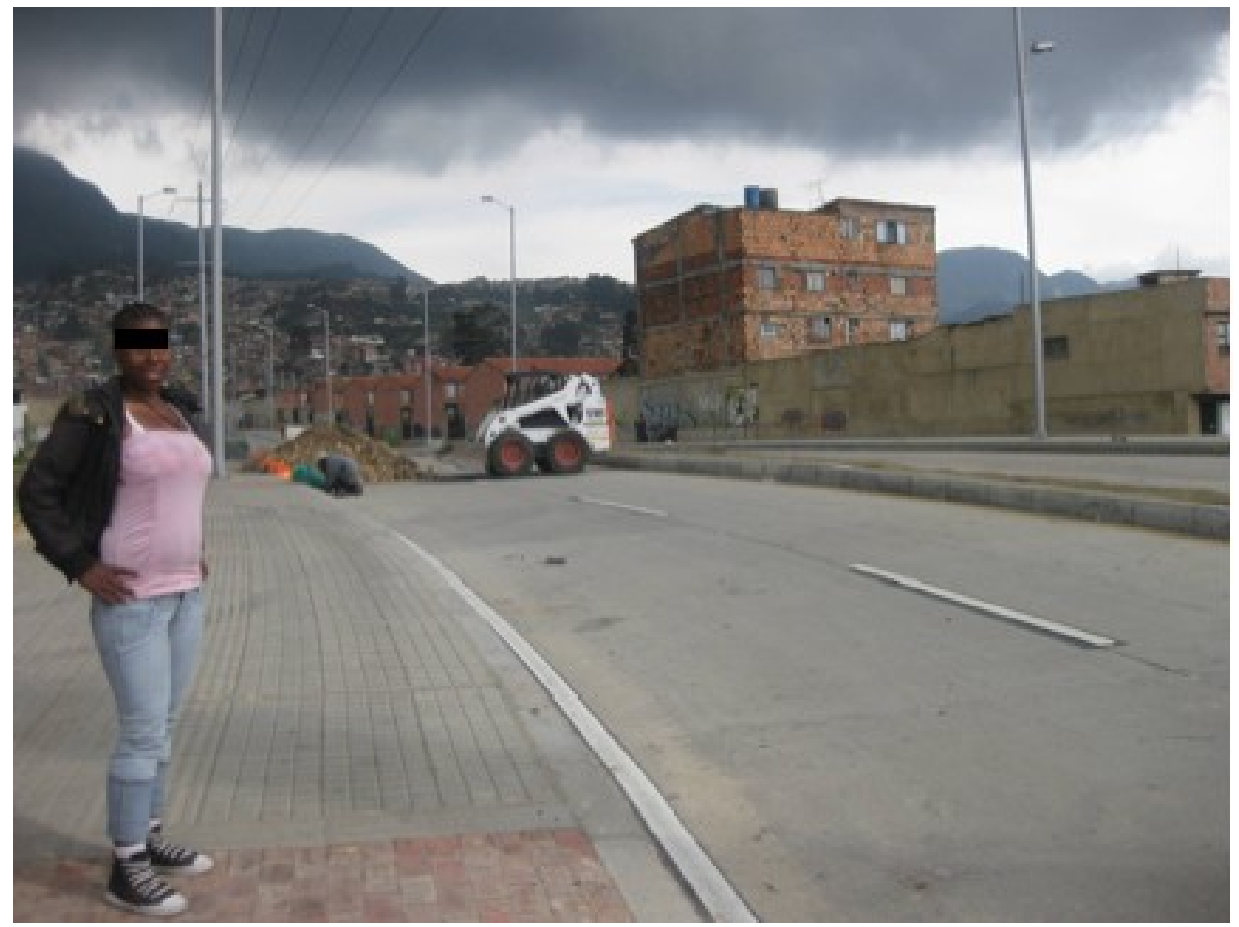


Ahora casi no reconozco este barrio donde antes vivía - queremos saber como podemos recuperar el barrio para que no desaparezca como El Cartucho... hay mucha construcción, estan tumbando casas, y el espacio esta cambiando sin tener en cuenta la comunidad.... (Now I hardly recognize the neighborhood where I used to live... we want to know how we can take back our neighborhood so that it does not disappear like El Cartucho...there is a lot of construction, they are knocking down houses, and the space is changing without taking the community into consideration) (El Cilencio and El Guapo, ${ }^{14}$ YPAR Presentation May 26, 2010).

Walking through Las Cruces barrio (neighborhood) with Satanás, ${ }^{15}$ another transient member of the YPAR team, we encounter a similar street scene as in la ' $L$ ' but limited to two main alleyways where drugs are consumed and pegante (shoe glue) is sold by the dozens of bottles...in Las Cruces, construction and 'urban improvement' are already well underway as noted by El Cilencio, while standing by the newly paved sixth street (the renovation of which led to the displacement of estrato 0 (socio-economic stratum 0 )

${ }^{14}$ El Guapo, Lo que me Obligan a Callar (Good Lookin', What They Don't Let Me Say) is a pseudonym chosen by another principal research actor of the YPAR team to protect her identity in both participatory writing workshop excerpts and other original text included throughout the dissertation. In the remainder of the text, she will be referred to as El Guapo.

${ }^{15}$ Satanás (Satan) is a pseudonym chosen by another principal research actor of the YPAR team to protect her identity in both participatory writing workshop excerpts and other original text included throughout the dissertation. 
families. ${ }^{16}$ As noted above, El Guapo hardly recognizes the neighborhood where many childhood place memories are based...besides the park that remains intact because of its location between the barrio's church and police station.

Las Cruces is a historically significant neighborhood in Bogotá, being the birthplace of the urban hip-hop movement and for its location next to the President's palace, Congress headquarters, and Bogotá's local governmental program offices. At the same time Las Cruces is the place where many street girls earned their first gang tattoos, were initially introduced to street prostitution and petty theft, and gradually transitioned from pick-up soccer games in the park by day to glue sniffing in its corners by night.

\section{Study Site 4: El Samber}

Leaving Las Cruces and crossing la décima (10th Avenue) where Transmilenio construction is currently underway (significantly altering street girls' spaces in this areasee chapter five for discussion), we enter barrio San Bernardo, or, in street girl speak, El Samber.

\footnotetext{
${ }^{16}$ Estratificación socioeconómico (socio-economic stratification) in Colombia was established in 1981 when la Junta Nacional de Tarifas (National Price Setting Committee) in Bogotá required public service companies (gas, water, and electricity) to stratify rates according to the zones of the city in which they provided service. The socioeconomic stratification system was not legally formalized until July 11, 1994 when Congress passed la Ley 142 de 1994 (Law 142 of 1994) establishing the stratification of the public service system (Uribe 2008). Social strata in Colombia range from 0 to 6 . The discourse of stratum and class has been appropriated by Colombian society moving beyond public service receipts to everyday use, class identity formation, and status claims, especially in youth populations (according to members of the YPAR team). The estrato complex is notably present within popular discourse throughout the country (as much in higher social strata as in lower).
} 


\section{$\underline{\text { Photograph 1.4: El Samber }}$}

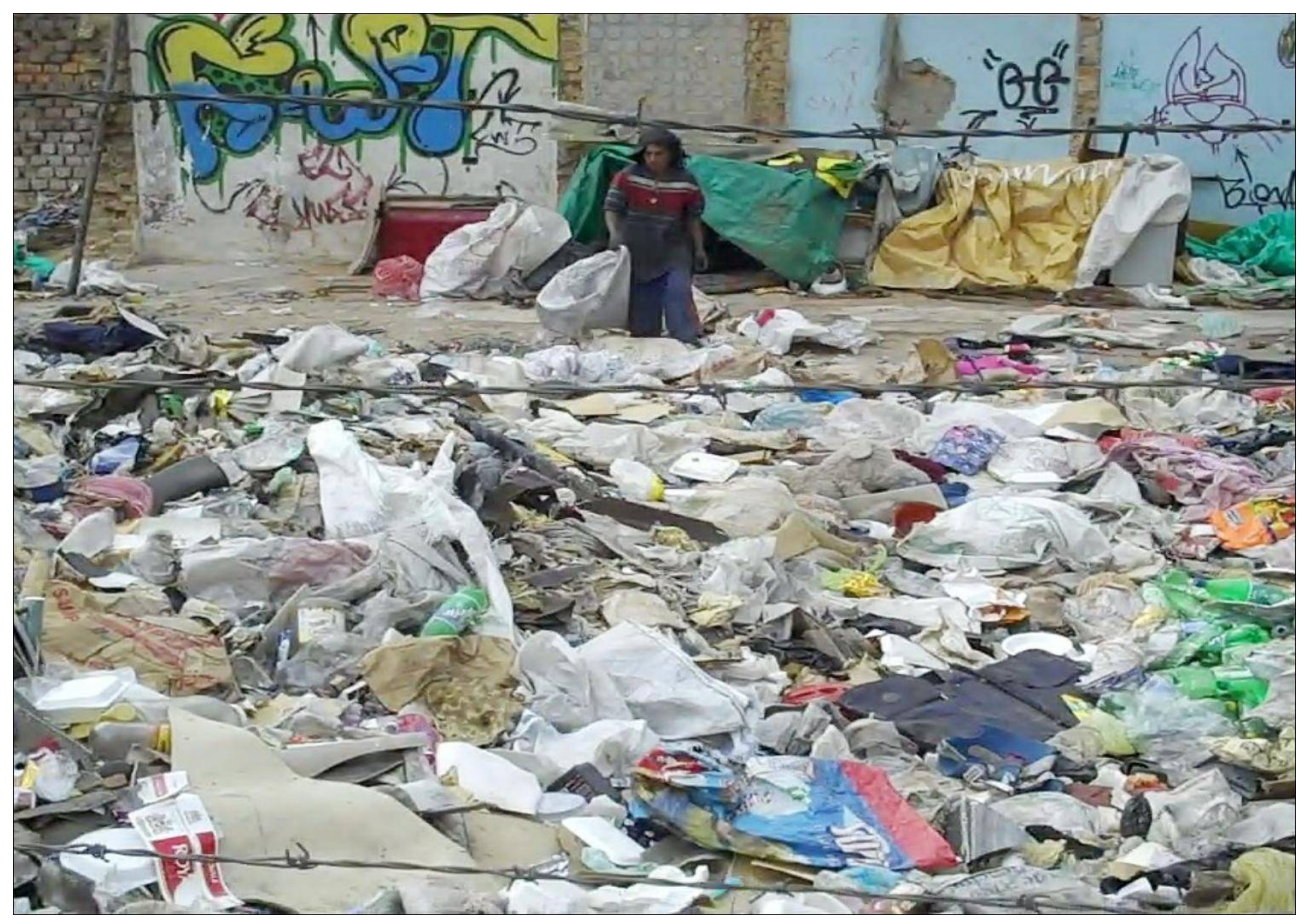

As described by El Guapo: "El San Bernardo es un espendido de drogas que

queda directamente al sur del parque tercer milenio (cerca a la Mariposa)...Cuando no hay otra opcion de escape, escapamos en El Samber ... a veces los jibaros ponen a las chicas a trabajar para ellos mismos...y si no trabajan para los jibaros, trabajan para las parejas o para el vicio...(E1 San Bernardo is a drug distribution area [drug zone] located directly south of El Parque Tercer Milenio [another spatial cleansing case - see chapter five] and close to la Mariposa [two blocks north of El Parque Tercer Milenio]... When there is no other escape route, we escape to[/in] El Samber [escape from the workplace and escape from physical space through drugs]...sometimes the drug dealers have street girls work for them ... and if they are not working for drug dealers, they work for their partners or for drugs" (El Guapo, YPAR Presentation May 24, 2010). 
On a YPAR team sketch-map tour (conducted in each study site to collect

information for the base maps, see section ) El Cilencio noted that she,

...[V]es una mujer en una esquina totalmente degenerada arruinada por el vicio hablando con un tipo totalmente desagradable depravado quizas con alguna enfermedad de transmission sexual la muchacha ansiosa por consumir ofrece su cuerpo por 10 mil quizas 7 mil o 5 mil o 2 mil una bicha o quizas un pipazo... aquel hombre desagradable ... alli los hombres son FEOS... al ver que esa oferta esta tan jugosa empieza a manocearla.. se la lleva a una esquina....le dice que se lo chupe a cambio de su droga...en las ollas donde se vende el vicio a veces se ve gente cambiando su pertenencias, su ropa, tenis, celulares, portatiles, mp $3 s$, Ifones, televisores...hasta el putas...hasta su madre son capaces de vender a cambio de vicio....en dias callados, trankilos, donde se siente una paz completa no se imagina lo que se le viene encima, operativos, policias acabando con todo lo que encuentran a su paso, tumbando puertas, a cambio de encontrar drogas...en muchos casos vemos como la gente es agredida, gente que se encuentra muerta sin saber quien lo hizo, porque sucedio y tambien sin poder opinar ni hablar de lo que paso...porque son encontrados de la misma forma de aquel cuerpo anterior ...vemos niñas de 10, 12, 13...paradas en una esquina para sostener su medicina o quizas, lo peor, para su maridos o madres infelices que son capaces de vender a sus hijas para consumir ellas...por alli transitan buses, taxis, carros, mucha gente hasta al gobierno pasa ignorando todo lo que alli pasa...vemos niños entre 8 y 10 años entrando en las rockolas a pedir monedas para su comida...entras a una rockola ves maquinas, gente fumando bazuco, otros fumando marijuana, otros jugando maquinas carramaniados, y mujeres dejandose manocear para un pipazo...tambien hay hoteles, casas y hasta un colegio (El San Bernardo)...calles despabimentadas, construcciones sin terminar, lotes destruidos, $e$ indigentes viviendo en estos lugares...vemos un hombre golpeando a su mujer...dos hombres apuñaleandose...jivaros corriendo de la policia y escapando en un taxi o tambien disfrasandose como locos para no ser descubiertos...(You see a woman completely wasted away, ruined from drug use, on a corner talking to a guy, totally disgusting, depraved, probably with some kind of sexually transmitted disease, the girl, anxious to consume, offers her body for 10 thou[sand], maybe 7 or 5 or 2 [from 5 to less than one dollar]...[or even] a joint or a hit...that disgusting guy...the guys there [in El Samber] are UGLY...with the offer gets so excited he starts feeling her up...he takes her to a corner and says to suck it in exchange for his drugs...in the ollas where they sell drugs...sometimes you see people exchanging their belongings, their clothes, shoes, phones, computers, mp3 [players], Iphones, televisions...even the whores [the expression, hasta el putas, beyond the 
literal translation implies 'everything under the sun']...they are even capable of selling their mothers for drugs... on a quiet, 'calm' days in El Samber...you don't see what's coming....police raids confiscating everything they find [to then re-sell it]...knocking down doors...to find drugs...many times we see how the people are attacked...people are found dead without knowing who did it, or why it happened and also without being able to give an opinion or talk about what happened...because they are found in the same condition as the last body... we see girls 10, 12, 13 [years old] on the corner to feed their habit [medicine referring metaphorically to drugs], or maybe, even worse...for their husbands or mothers who are capable of selling their daughters to get drugs...buses, taxis, cars, many people even [from] the government pass by ignoring all that is happening there...we see children between 8 and 10 years [old] going into the rockolas to beg [for coins] for food...you enter into a rockola and you see [casino] machines, people smoking bazuco, others smoking marijuana, others playing [gambling] on [rigged] machines... and women letting themselves be touched for a hit...there are also [pay-perhour] hotels, houses, and even a secondary school (the San Bernardo)... unpaved streets, unfinished construction, destroyed [vacant] lots...and homeless people living in these places...we see a man beating up his woman...two men stabbing each other...drug dealers running from the police and escaping in a taxi or disguising themselves as crazies to not be discovered...) (El Cilencio, YPAR Presentation, November 17, 2010).

As guest speaker during one of our YPAR presentations, El Cilencio read her narrative in front of a large audience at a U.S. Embassy event the YPAR team was invited to as the guest speaker or 'feature' presentation. The audience sat in silence. In the question and answer period, many conferences attendees recalled passing this area (as $10^{\text {th }}$ Street is currently a main bus route and will be a Transmilenio route) but never imagined such a place existed just beyond the vacant lots... 
Study Site 5: Santa Fé (the zone of tolerance) ${ }^{17}$

\section{Photograph 1.5: Santa Fé}

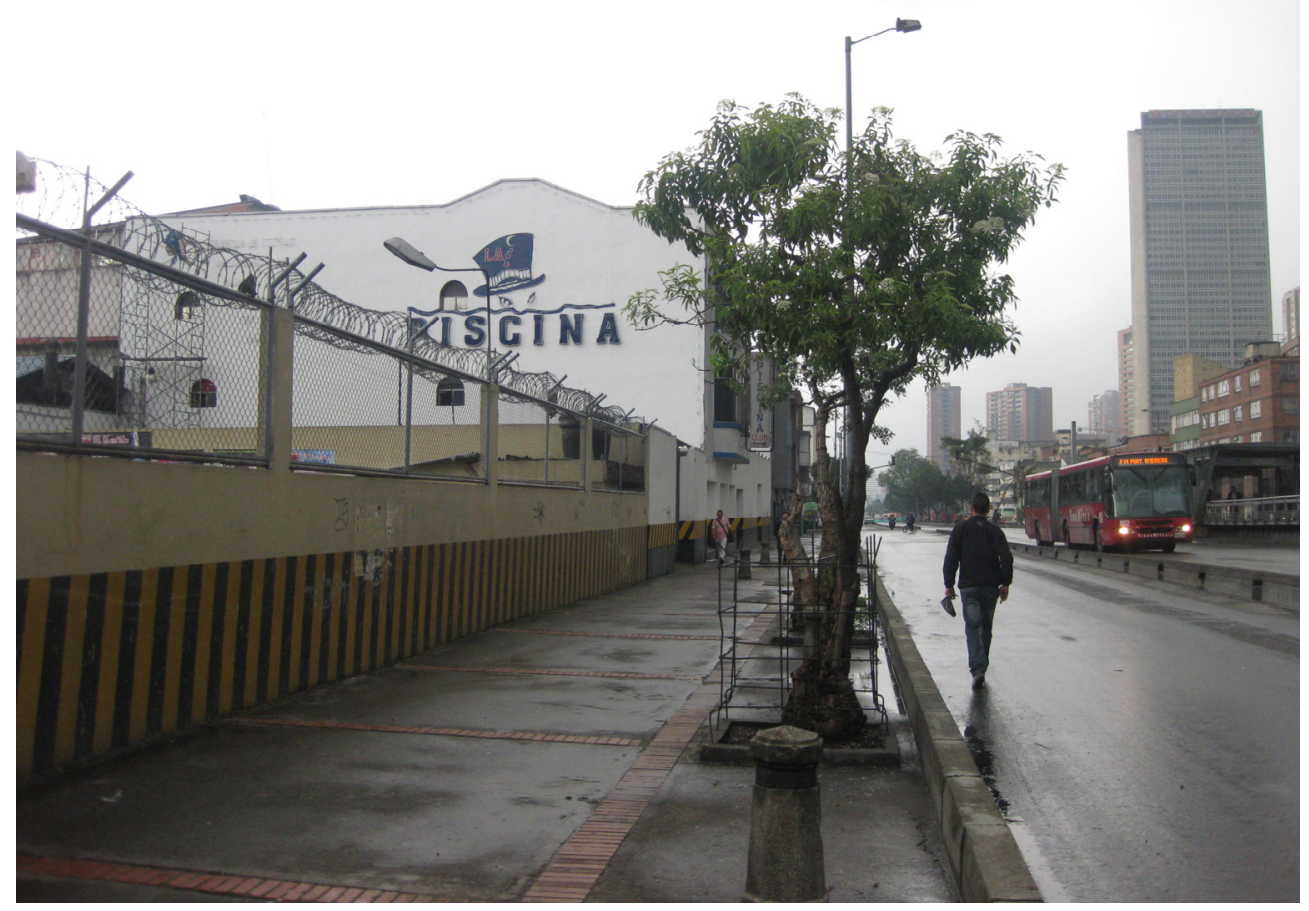

${ }^{17}$ Literal translation of zona de tolerancia i.e., red light district, an area of legally tolerated and accepted public prostitution according to the city's Código de Policía (a municipal decree detailing norms for enforcement of social order and regulation of public spaces, enforceable by police). For more information see:

http://legislacion.vlex.com.co/vid/codigo-policia-bogota-c-42867933, accessed

November 4, 2010. 


\section{Photograph 1.6: Santa Fé}

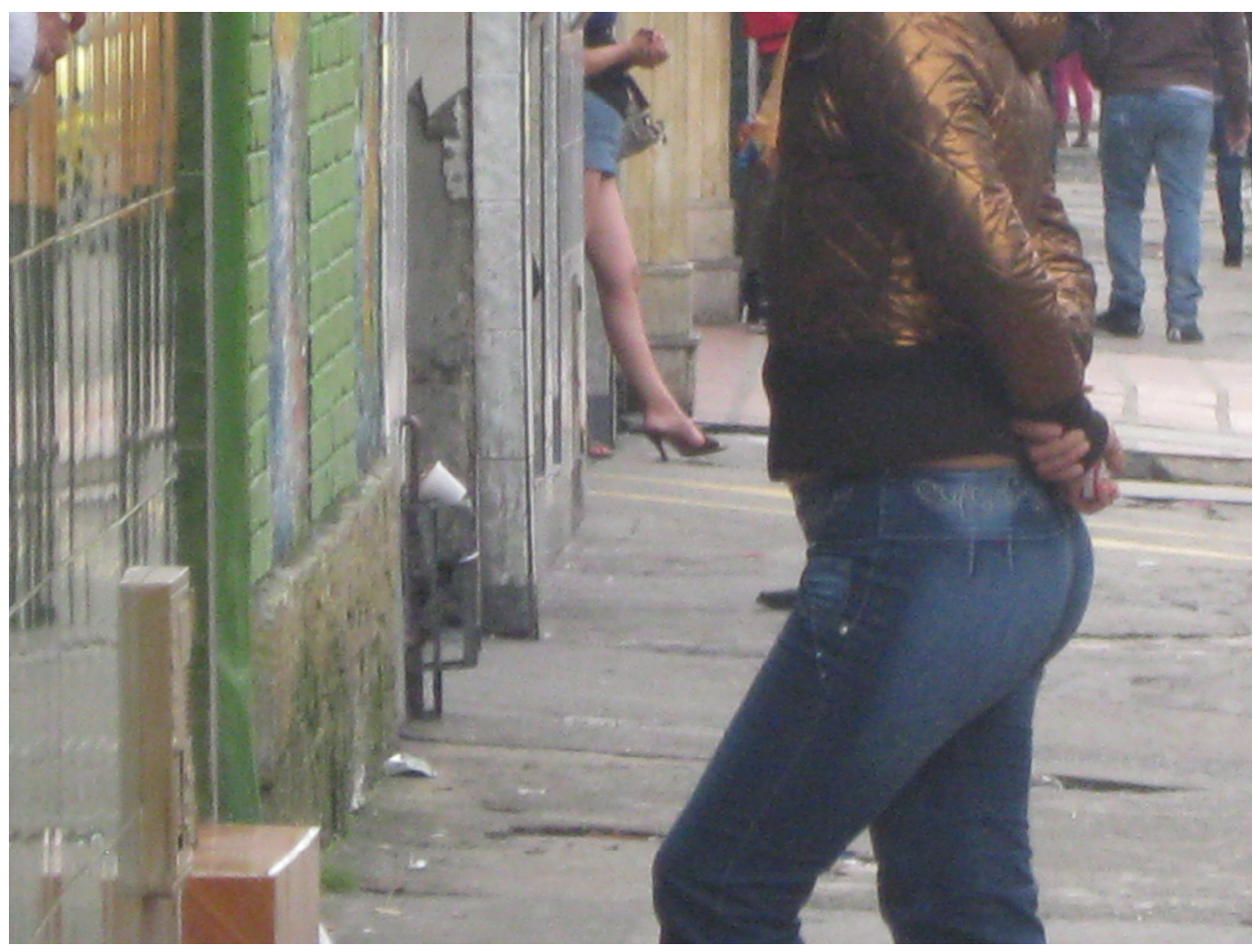

Photograph 1.7: Santa Fé

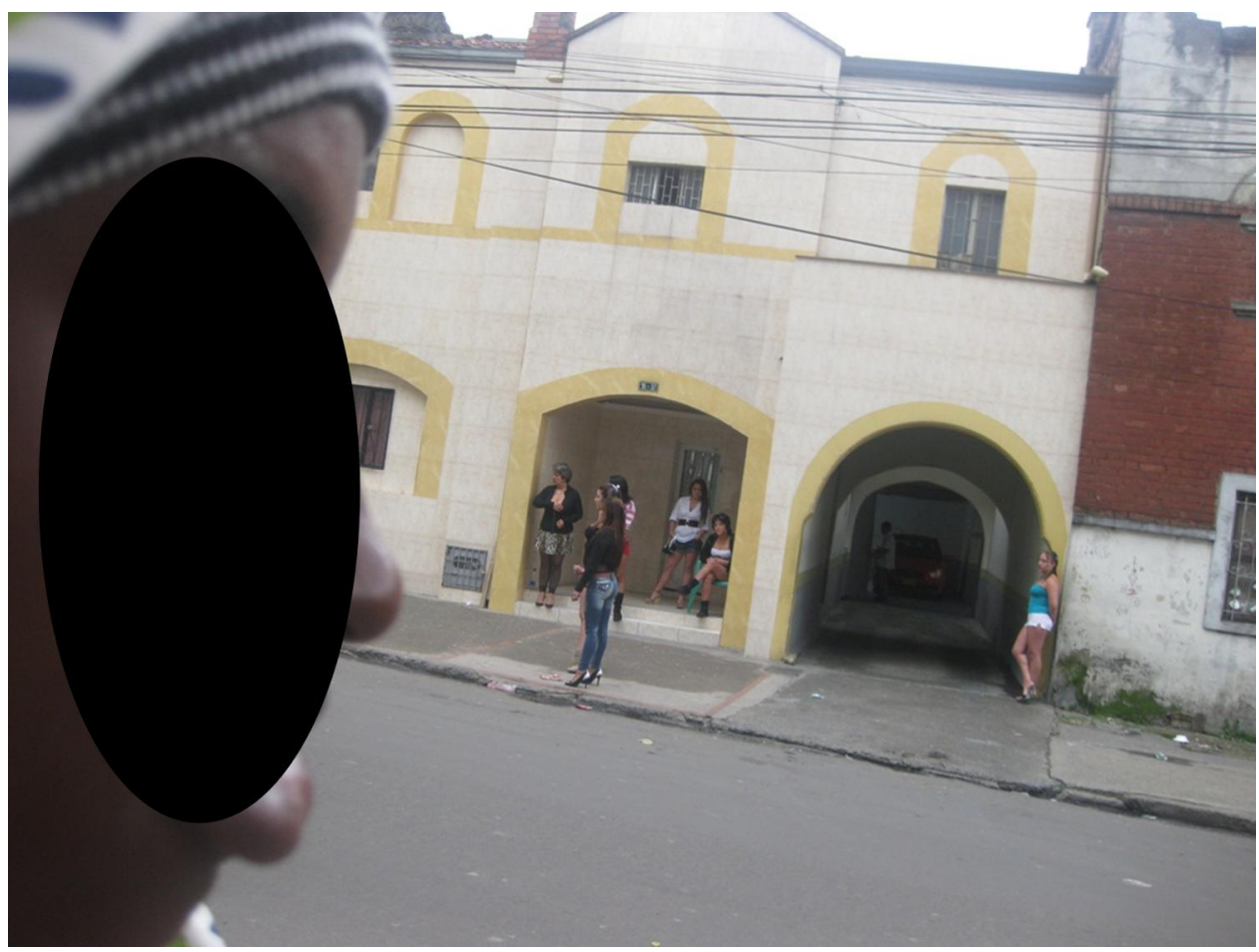


¿Crees que rechazar y ver morir alguien por su orientacion sexual es justo en esta sociedad? (Do you think that rejecting and watching sometime die because of their sexual orientation is just in this society?)" (Yolanda and Daya ${ }^{18}$ YPAR Presentation, May 26 2010).

During our first YPAR presentation at Universidad de los Andes (University of the Andes located in the center of Bogotá and Colombia's most prestigious, and expensive, private university) ${ }^{19}$ the girls directed questions to the audience as a means of beginning the discussion and description of each study site. Yolanda and Daya, two chicas trans (transgender girls) and peer leaders who directed the Santa Fé trans- portion of the project, designed their question surrounding hate crimes to introduce barrio Santa Fé, Bogotá's zona de tolerancia (zone in which prostitution is legally tolerated) where

${ }^{18}$ Yolanda and Daya are pseudonyms chosen by two principal research actors of the Transgender subgroup of the YPAR team to protect her identity in both participatory writing workshop excerpts and other original text included throughout the dissertation.

${ }^{19}$ This presentation was organized by Universidad de los Andes Development Studies Research Center (CIDER), which served as my academic institutional affiliation during the Fulbright Fellowship for the 2009-2010 academic year. As a visiting researcher at CIDER, I was invited to give a seminar entitled Iniciativas de desarollo urbano y exclusion socio-espacial de las jovenes en el centro de Bogotá (Urban development Initiatives and the socio-spatial exclusion of female youth in the center of Bogotá). This seminar was attended by faculty and researchers of CIDER and other departments at Universidad de los Andes, technocrats and officials from Bogotá's Institute of Urban Development (IDU), academics from other institutions, (la Universidad Nacional, la Javeriana, Universidad del Rosario) other Fulbright scholars based in Colombia, local activists and NGO employees (Fundación Procrear, Fundación Fenix), and other officials from governmental entities working with urban youth, prostitution, public health and urban development. Seven members of the YPAR team presented our research, as I insisted that the girls be included as co-panelists on event publicity and that the seminar reflect the participatory nature of the project. Universidad de los Andes is extremely securitized and logistics of the event were difficult to organize (including obtaining access for the girls since none of them have identification cards and preventing any feelings of exclusion or rejection upon entering one of the most elitist spaces in Bogotá). 
hate crimes, rejection, sex clubs, brothels, and police and paramilitary violence demarcate the geographic dimensions of their exclusion.

Santa Fé, historically an estrato 6 neighborhood splotched with mechanic shops and car wash stops, is Bogotá's legally 'tolerated' zone of prostitution full of brothels, street nudity and exposure, drug houses, paramilitary occupation, and the scene of social cleansing targeting transgender sex work populations.

El Guapo describes Santa Fé as the following:

...[S]on las 6:30 de la mañana...veo niños iyendose para su colegios, transebuntes iyendo hacia las tiendas hacia sus trabajos o de regreso hacia sus casas...veo unas muchachas paradas en la esquina esperando un cliente...despues se escucha un grito...una pareja atracado a una persona...vemos patrullas, taxis, motos, 9:30 de la mañana se terminan de abrir todos los negocios cerrados...vemos restaurantes, hoteles, rockolas, tomaderos, prostibulos, almacenes, supermercados, obras, las cabinas, peluquerias, iglesias, agencias de Chance, internet, casinos, niños jugando en el parque, muchachos peganteados en las equinas, locos durmiendo en la calle, clientes borrachos..travestis agarrandose por clientes, muertos en los puteaderos...mujeres, niñas y adolescentes en puertas ...en las esquinas...dentro [de] los establecimientos...enfrente de los hoteles esperando clientes...las niñas...menores de edad, se ubican en una esquina en grupos, consumen pegante, marijuana y pepas, y esperan para los manes que llegan en moto, carro, ciclas, y a pata se las lleven...pero lo que no se esperan es que estas niñas a tan corta edad son ladronas, o muchas veces asesinas...son victimas de su propio invento porque salen sin su pertenencias o en casos salen apuñaleados o muertos... hay tres calles principales de clubes...donde entran mujeres y adolescentes a trabajar...para ingresar toca entrar en falda bien cortico...camisas descotadas...bien putiperras...entro...me siento en la barra y me dan trago....esperando...que llega el hombre a follar conmigo...nos sentamos a dialogar...dialogamos del precio del polvo....subimos a la habitacion....nos dan 15 minutos para consumar el acto...y esa es la vida que se vive al diario en el Santa Fé...(It's 6:30 in the morning...I see kids going to school...[people] walking to stores, to their work or on the way back to their homes...I see girls standing on the corner waiting for a client...I hear a scream...then I see a couple attacking someone...we see cop cars, taxis, motorcycles, 9:30 in the morning [and] the businesses finish opening... we see restaurants, hotels, rockolas, bars, brothels, [clothing stores], supermarkets, construction, telephone and 
internet cafes, beauty parlors, churches, casinos, children playing in the park, kids high on glue on the corners, crazies sleeping in the street, drunk clients...transvestites fighting over clients...dead people in the brothels...women, girls and adolescents in the doors... on the corners... inside the businesses... in front of the [pay-per-hour] hotels waiting for clients...the girls...the underage [ones]...gather in groups on a corner...do glue, marijuana, and pills, and wait for the guys who arrive in motorcycles, cars, bikes, and by foot...they take them but what they don't expect is that these [young] girls [...] are thieves, or many times killers...they [the clients] are victims of their own making because they leave [the brothel] without their possessions or sometimes leave stabbed or dead...there are three principal streets of clubs [each known, amongst the girls, by club name rather than street name]... where women and adolescents go to work...to get in you have to enter in a very short skirt, low-cut shirt...very whorish [...]...I enter...I sit at the bar and they give me liquor...waiting...for the man to come and screw me...we sit to talk...we talk about the price of the screw...we go up[stairs] to the room... they give us 15 minutes to consummate the act... and that's the life that's lived daily in Santa Fé)(El Guapo, Participatory Writing Workshop, October 14, 2010).

\section{Research Design and Methodology}

My dissertation research employed a multi-method approach to uncover sociospatial relations and re-envision urban space. The significant methodological contribution of this research on street girls' social and spatial lives in Bogotá, Colombia lies in the innovative triangulation of participatory mapping methods, ethnography, and autophotography. The research design follows the approach of children's geographers that have used participatory and auto-photographic methodologies (see for example, Cahill 2007; Kesby 2007), qualitative and feminist GIScience with the objective of creating counter-maps of urban space (see for example, Kwan 2002; Pavlovskaya and Martin 2007), environmental and behavioral geography's elaboration of cognitive and activity mapping methodologies (see for example, Lynch 1960; Golledge and Stimson 1987), and ethnographic techniques including participant observation, interviews and focus groups 
(see for example, Geertz 1973; Wolf 1996; Crang and Cook 2007). These methods were employed in a six-phase research process (see below) during a period of eighteen months in two central localidades (districts) of Bogotá.

Research was conducted in the central districts Santa Fé and Los Mártires, both having an identified presence of street girls. Pilot research was conducted in 2004 to identify these sites and establish communication with a key informant, Timothy Ross, of Fundación Social Fénix. ${ }^{20}$ During preliminary research and collaboration with the YPAR team, five study sites were chosen because each has a concentration of urban improvement efforts and presence of street girls and one additional site, Chapinero, was added to include another transgender dominated area of prostitution.

\section{Target Population and Recruitment}

I used a snowball recruitment approach to identify a population of thirty-three female street youth between the ages of seven and thirty years old. As previous research has shown, "qualitative studies with young people require prolonged interaction with research participants, not only to understand their life worlds, but also to form

20 "Fénix is a not-for-profit foundation, registered in Colombia as 'Fundación Social Fénix', providing educational assistance, group support, peer leader mentoring, tutoring and leadership training to vulnerable young people without resources. Fénix developed out of the experience of supporting girls from a child care programme in the difficult transition to independent living and tertiary education, assisting them in choosing and entering degree courses, finding financial assistance and scholarships, supplying computers and text-books and providing guidance and support when needed. The programme goal is to prepare highly motivated young adults, well-educated in social and health science professions, trained as peer leaders and committed to working with socially excluded and vulnerable groups, who otherwise would have little chance of achieving their full potential. Their own experiences of neglect, abuse and institutional life give them invaluable knowledge and understanding and a greatly enhanced ability to work with other young people at risk or in youth institutions, thus contributing significantly to an improved quality of care and eventually to programme leadership and policy generation" (http://fenix.org.uk/ accessed October 2010). 
relationships, build rapport and gain mutual trust" (Langevang 2007, 271). Therefore, the sample size of thirty-three participants is appropriate given the need for prolonged engagement with each participant. Recruitment was guided initially by Mr. Ross who, with over twenty years experience, has established trust and standing within this population and is embedded in a diverse network of activists, scholars, and outreach workers engaging daily with female street youth. Collaboration with these contacts at different institutions (governmental, non-governmental and academic) including Fundación Social Fenix, Fundación Procrear, Asociación Cristiano de Jóvenes (ACJ - El Refugio), and Instituto Distrital para la Protección de la Niñez y Juventud (IDIPRON) located in distinct sectors of the study area attenuated potential bias within the sample selection.

The project and instrumentation obtained IRB approval on September 11, 2008 and was renewed on December 1, 2009 in order to adjust for changes regarding the (trans)gender identity of the final 10 participants. Standard methods of data security and human subject confidentiality protections were followed.

\section{Participant Observation: Phase I}

The 'researcher' became familiar with the behaviors and socio-spatial context of street girls, established rapport with potential participants, and began recruitment. Exploratory Interviews: Phase II

Each girl selected an interview location where she feels comfortable. Lasting for one hour, the semi-structured interview explored the life history of each participant, the home/homeless duality, and the vision of the city from the 'child's eye view.' 
Auto-photography and Place Perception Interviews: Phase III

Participants were given disposable cameras to take pictures of places that are significant in their lives over a period of one week. After the photographs were developed, each participant recounted the journey represented by the photographs (childled place perception interviews) and made a collage reflecting the story of her placeworld. This method gave the researcher access to places "where the actual physical presence of the researcher would have affected and distorted the situation" and therefore the potential for Hawthorne effect was considerably decreased (Young and Barrett 2001, 391).

Cognitive and Activity Mapping: Phase IV

The objective of this phase was to create counter-maps of the city that visually represent Bogotá as seen through the eyes of street girls (Kwan 2002a). On a map of the study area, participants located their daily activities and revealed their perceptions of places in the city using colored pencils. Spatial variables were added after completing phases I-III after receiving input from other research actors during participatory mapping workshops (see chapter five for comparison of proposed variables and the variables developed by the YPAR team of street girls). 


\section{Photograph 1.8: Mapping Interviews}

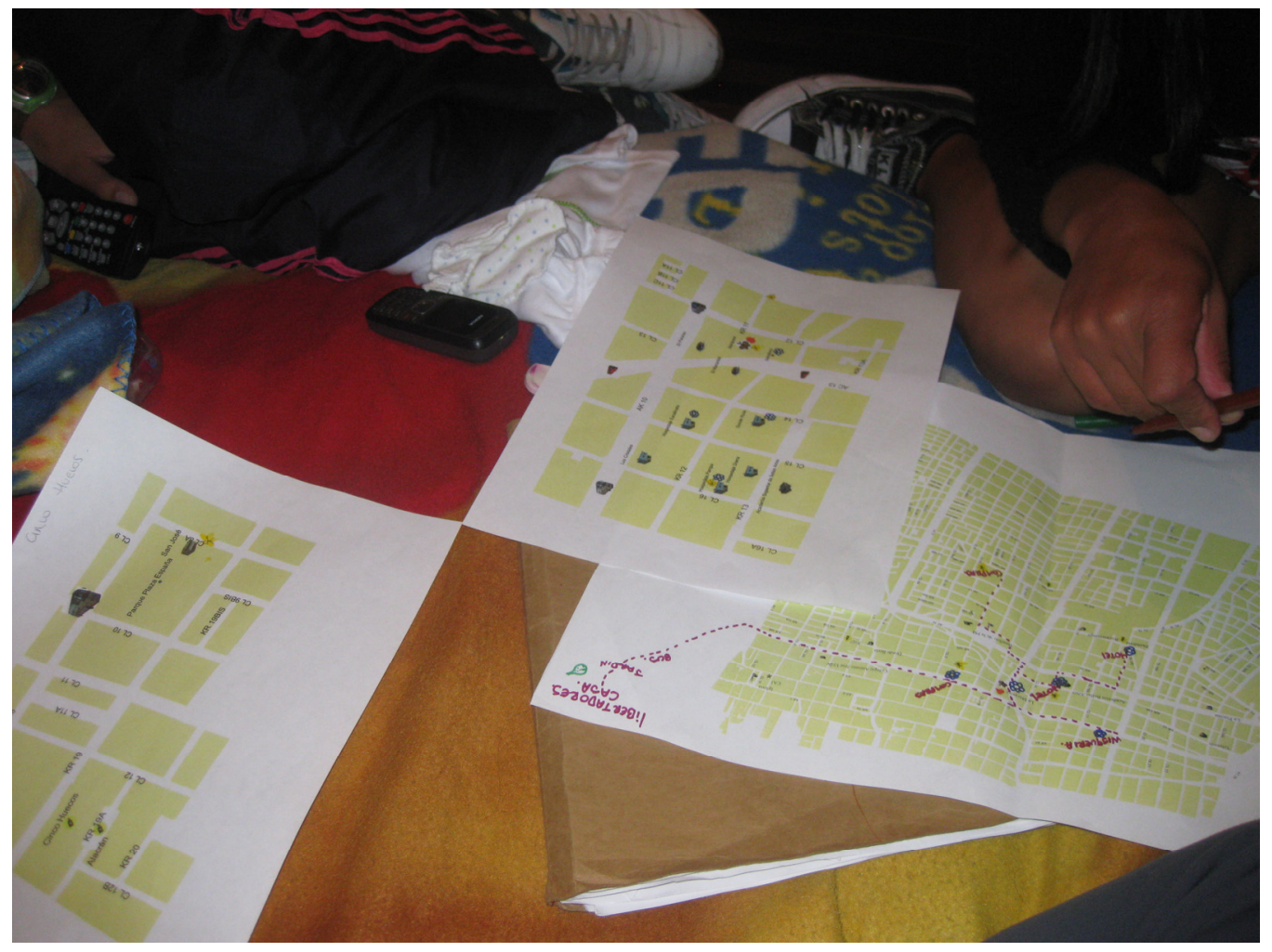

\section{Roving Focus Groups: Phase V}

The YPAR team selected five groups of four to five research actors who planned and embarked on a geographical expedition through the city while discussing the significance of each destination along the way (Bunge and Bordessa 1975; Anderson 2004; Inwood and Martin 2008; Evans and Jones 2011). Physical presence within street girls' activity spaces during the focus groups enabled research actors to spontaneously discuss the memories and feelings invoked by the urban environment in general and specific places we passed while walking and talking. 


\section{Photograph 1.9: Roving Focus Groups}

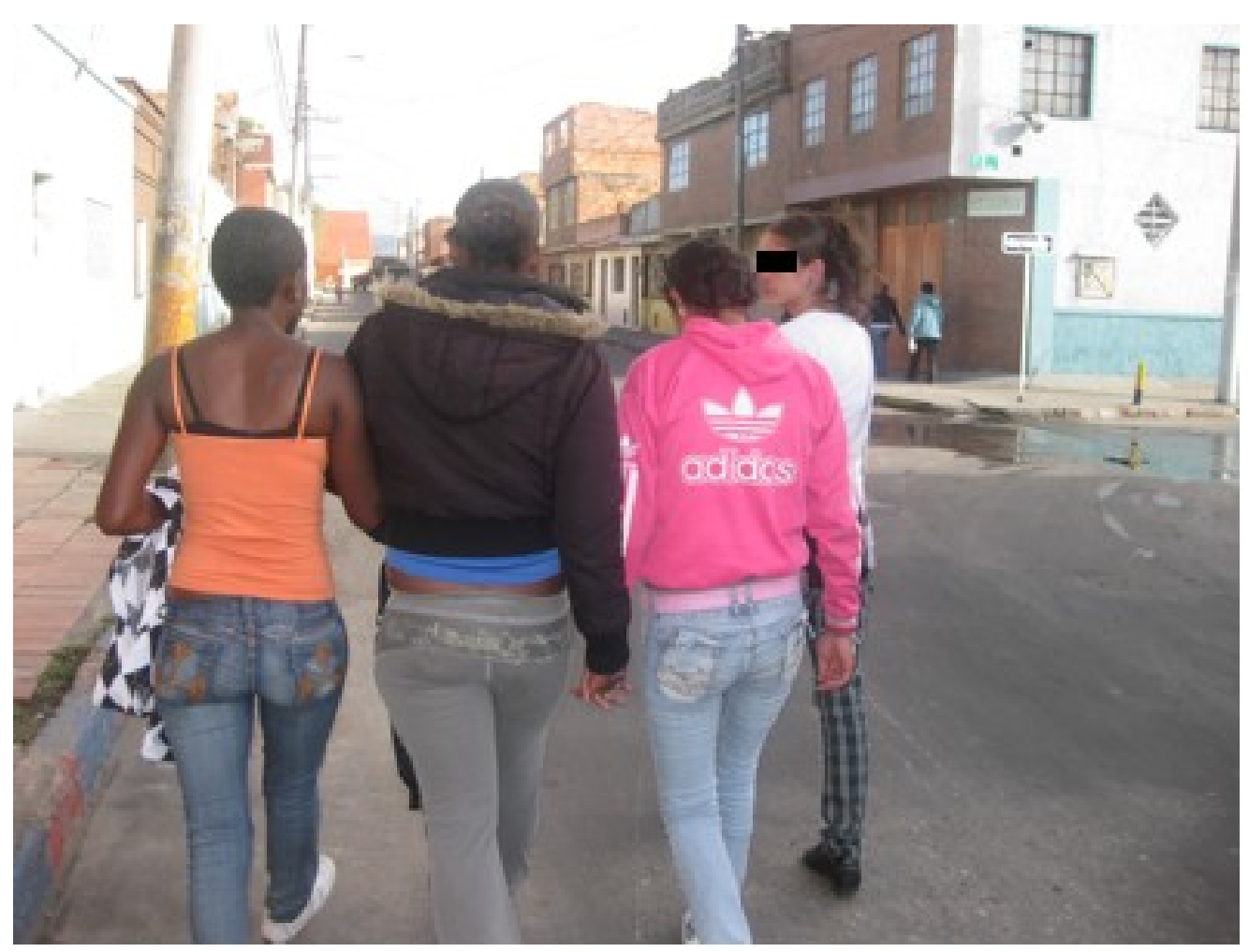

Consultation of Primary and Secondary Sources: Phase VI

As a visiting researcher at the Development Studies Research Center at Universidad de

Los Andes, contributing to the Center's Inequality and Vulnerability research line, I worked with affiliated scholars to access primary and secondary sources. These sources include two local newspapers (El Tiempo; El Espectador) and policy documents from five local institutions involved with urban youth (Instituto Distrital Para la Protección de la Niñez y Juventud; Instituto Colombiano de Bienestar Familiar; El Departamento de Integración Social; El Viceministerio de la Juventud; UNICEF Colombia). 


\section{Data Analysis}

I used ESRI ArcMap 9.3 to analyze the spatial data collected during the participatory mapping exercises and NVIVO7 was used to code and analyze transcribed interview and focus group data, field notes and primary documents collected during phase VI.

\section{Structure of the Dissertation}

Chapter two places the dissertation material within the broader context of Colombia representing violence and conflict, both popular characterizations of Colombian everyday life, as seen through the eyes of streets girls. This chapter takes us from a 'blind money' to 'street honey' view of Colombia.

Chapter three reviews the literature of the conceptual framework underpinning this dissertation by synthesizing relevant concepts from three principal bodies of literature: geographies of exclusion, Children's Geographies, and feminist visualizations of urban space.

Chapter four reveals street girls' personal perceptions and feelings of exclusion through narratives incorporating fieldnote, interview, and participatory writing workshop excerpts. Several principal research actors (myself included) discuss how methodologies and field praxis were developed most effectively to research exclusionary processes and their impact on the lives of street girls.

Building on this field context, chapter five presents the spatiality of street girls' perceptions of the city and how street girls' activity spaces intersect with broader processes of urban change and renovation in Bogotá. Using a visual approach to knowledge construction, the chapter presents a street girl and street corner cartography documenting streets girls' activity spaces and perceptions of the city before, and in the 
case of la 'L', after urban 'improvement' efforts change the face of the study sites and displace street girls' from their activity spaces. Both chapters four and five interweave discussions of data and methods, focusing particularly on street girls' role in developing methods and the impact of this participatory approach on their everyday lives.

Chapter six summarizes research findings and provides conclusions derived from the methodological contributions and findings discussed in chapter four and five. 
II. Re-framing Violence in Colombia: From Blind Money to Street Honey

Chapter two describes the local and national context of violence within which Bogotana street girls' everyday lives and geographies are intertwined, both historically and in their current urban context. The discussion begins with the political milieu that marked the beginning of La Violencia with the assassination of presidential candidate Jorge Eliécer Gaitán and then provides a brief history of the polarized grupos armados (armed groups) of las FARC - Fuerzas Armadas Revolucionarias de Colombia (Revolutionary Armed Forces of Colombia) and los Paramilitares (Paramilitary Forces). In order to move beyond these typical constructions of violence in Colombia, the chapter includes writing workshop excerpts in which street girls express their perceptions of violence in the city and how it affects their lives.

Violence in Colombia and in Street Girls' Lives

La violencia (violence) in Colombia must necessarily be situated within the deeply rooted partisan rivalry between the liberal and conservative parties, dating back to la Guerra de los Mil Días (Thousand Day War), 1899-1902, which marked the beginning of conservative hegemony until internal divisions led to the fall of the conservative party and the change of government in 1930 (Oguist 1978). The era known as La Violencia (The Violence), from $1946-1966$, “...was the scene of one of the most intense and prolonged instances of civil violence in contemporary history," the death toll of which has been estimated at over 200,000 (Oguist 1978, 11). Violence surged during the electoral campaigns of 1946 as rivalry between liberal candidates Gabriel Turbay and Jorge Eliécer Gaitán led to the division of the liberal party and the subsequent election of Mariano Ospina Pérez of the conservative party. Between 1946 and 1948, the heart of La 
Violencia was geographically concentrated in the Departments of Santander del Norte, Santander, Boyacá, and Cundinamarca, the regions also most affected by partisan violence in the 1930s (Ibid, 15; Payne 1968). During this period, political violence also spread throughout the departments of Nariño, Valle de Cauca, Antioquia, Tolima, and Caldas in the west (Ibid, see Map 1.1). Tension between the Conservative and Liberal parties rose in attempts to place blame for the deaths that resulted from partisan violence, while rising inflation and strikes contributed to overall social discontent nationwide (Ibid). In the midst of this social, political and economic context of nationwide unrest, Jorge Eliécer Gaitán was assassinated on April $9^{\text {th }}$ of 1948, a day in which the capital city, Bogotá, “...became a scene of urban chaos, with part of the police supporting the opposition. Other cities and populations also united, openly challenging the government...it was only through a bloody, military occupation of Bogotá that the government re-claimed control of the capital..." (Ibid, 16).

Through this historical context of conflict and civil strife that plagued Colombian society for the greater part of the twentieth century, we can begin to conceive of the role that violence plays in the everyday life of Colombians in general and street girls in particular.

But just how deep, some might ask, is violence embedded in the Colombian psyche? To what extent, as questioned by Taussig, are the killings in present day Colombia different from those in earlier time? "How do I know it's not the same old killings that have surged through the town in waves since the early 1980s?..It's a different kind of killing, people tell me" (Taussig 2003, 26). Have acts of violence changed over time? As noted by Taussig, "[t]heir earlier tactic of appearing out of the blue in an 
isolated village, assassinating the inhabitants in grotesque ways, and then pulling out within hours or a few days has given way to this bizarre form of permanent occupation. What before was a silent attack across a rural landscape bleached by fear is now movement spinning in on itself like a child's top, emitting clouds of dust and confusion. It takes your breath away" (Taussig 2003, 22). To what extent does this 'new' form of violence penetrate Colombian society? Guzmán claims that la violencia in Colombia has fostered what he calls Tanatomanía ('Thanatomania,' derived from the Greek mythological figure Thánatos or the personification of death), "una obsesión de matar (an obsession with death)" (Guzmán 1968, 325). Is it accurate to limit conceptions of violence to the Self, as rooted in individual psyches, or is it rooted in the collective (national) unconscious, in the shadows of history?

Guzmán and Taussig's notions of violence may place in context what we see in Santa Fé, where bodies are disposed of daily, where transgender sex workers fall victim to drive by shootings, where death and murder are used as forms of control and as means of purging society of its toxins or parasites (which, for the Paramilitary running brothels in Santa Fé, are equivalent to travestis (transvestites)). As Taussig states in his diary of a limpieza in Colombia, a piece of paper (social cleansing name list) “...separates the living from the dead" (Taussig 2003, 26). The Spanish term limpieza, Taussig further notes, literally translates as cleansing or to purge the defiled or unclean but also "...has a far older history - in healing a person or a home from malignity resulting from a spirit attack or sorcery. Such healing not only neutralizes deadly force but enhances a sense of self in place and time" (Taussig 2003, xiii). 


\section{Re-framing Violence: Through the Eyes of Street Girls}

A closer examination of the term or etiology of violence, its various forms,${ }^{21}$ and how la violencia and acts of limpieza are lived and perceived by street girls, is in order. Moving on from this more common, but contextually important, discussion of violence in Colombia, we shift the focus to the war on street girls, urban violence and pueblo (small town) warfare that is silenced in many accounts of Colombian history, accounts of the conflict, and representations of violence in Colombia. In order to gain a closer view, I use the following narratives developed by Sentimientos Ocultos (Hidden Feelings), El Cilencio que Quiere a Gritos Decir la Verdad (The Silence that wants to Scream the Truth), and El Guapo 'Lo que me Obligan a Callar' (Good Lookin' 'What They Don't Let Me Say'), which are the pseudonyms chosen by three of the principal research actors that participated throughout the six research phases and writing workshops. ${ }^{22}$ These pseudonyms both protect the girls' identities and represent the positionalities they assume while writing. Through our writing workshops, the act of naming itself has become a form of political representation.

Sentimientos Ocultos presents her narrative dating back two years to a scene of violence in Chocó (a predominantly Afro-Colombian region on the Pacific coast of Colombia) and recounts:

\footnotetext{
${ }^{21}$ For example, physical, institutional, structural, permanent or transitory (temporal sense), inter-group or intra-group, inter-group or between individuals, official (from a state authority) or private (from informal/unassociated individuals or organizations), racial, military, machismo (gender); see Guzmán 1968, 497-499.

${ }^{22}$ Grammatical errors in the pseudonymous texts have been preserved.
} 
“Era el año 2008, eran las 2 de la mañana cuando yego un carro y empezaron a matar a todos los que estaban ayi cuando yo vi eso salli corriendo para salvar mi vida. en mi barrio no se ve paracos en mi barrio solo se ve Aguilas Negras donde ellos tienen el poder de todo y controlan todo...la matanza fue x [por] un motivo de venganza contra las Aguilas Negras $x$ [por] aver matado a un integrante de los paramilitares unos dias antes... $^{2324}$ (It was the year 2008, it was 2 in the morning when a car arrived and they started killing everyone that was there when I saw that I left running to save my life. in my neighborhood you don't see paramilitary in my neighborhood you only see Black Eagles where they have all the power and control everything...the motive behind the slaughter was revenge against the Black Eagles for having killed a member of the paramilitary a few days before...)" (Sentimientos Ocultos, Participatory Writing Workshop, August 15, 2010).

In addition to paramilitary violence, street girls' lives are also touched by urban warfare and the drug trade. El Cilencio provides a glimpse into la 'L,' the most devastated and dangerous olla in Bogotá:

“Estaba yo sentada en la rocola de Homero [en la ' $L$ '] ...llego una pareja a soplar despues de un par de oras. Uno de los Jibaros le coketio a la novia del muchacho en ese momento el muchacho disgustado iso un

\footnotetext{
${ }^{23}$ During our participatory writing workshops, we listen to audio files of the girls' interviews and then the write about and elaborate on their experiences after selecting themes for the dissertation chapter under construction.

${ }^{24}$ Grammatical and other errors in the original text have been preserved.
} 
reclamo, el Jibaro disgustado lo agredio fisicamente. Aquel joven disgustado saco un tres ocho cacha hueso apuntando al Jibaro en medio de su panico no penso cuando de un momento a otro salieron 5 manes mas con machete y empezaron a machetiarlo asta el punto de matarlo. Su novia fue raptada ...la subieron a la palomera...de ella no se bolvio a saber nada...de lo que pasó esa noche no se habló mas. Todo aquel que alli estaba era sordo, siego, $y$ mudo... ${ }^{25}$ (I was sitting in the Homero [a jukejoint and drug dealing/using spot in $\left.l a ' L^{\prime}\right] \ldots$ a couple arrived to get high [soplar literally 'to blow' = to smoke bazuco (cocaine base)] after a few hours. One of the drug dealers hit on the guy's girlfriend in that moment the upset guy objected, the upset drug dealer physically attacked him. This upset young guy whipped out a three eight cacha hueso [an ivory handled .38 revolver] pointing it at the drug dealer in the middle of his panic he was not thinking when suddenly 5 more men came out with machetes and started to cut him up until they killed him. His girlfriend was snatched [disappeared] ...they took her up to the palomera ... ${ }^{26}$ we haven't heard of her since... what happened that night was never mentioned again...everyone there went deaf, blind, and dumb...)" (El Cilencio, Participatory Writing Workshop, August 15, 2010).

${ }^{25}$ Grammatical and other errors in the original text have been preserved.

${ }^{26}$ A building in la 'L' where los Sallas (la 'L' self-appointed security enforcers and killers) take people to dispose of them. 
Violence is part of everyday life for street girls. They manage to keep on going with the day as they process massacre, rape and machete slaughters 'without weeping' (Scheper-Hughes 1992). Beyond these snapshots of violence as lived by Sentimientos Ocultos and El Cilencio, we move to the feelings and words of violence written by three street girls during a writing workshop on November 3, 2010:

Sentimientos de violencia (Feelings of violence)

Es el punto en que la persona llega a sentir verguenza hacia si mismo. llega a agredir o agredirse a si mismo. los sentimientos de violencia es un circulo vicioso donde empezamos por miedo a hablar y nos undimos hasta callar es el unico refujio que encontramos la lastima es nuestra mejor amiga el pesar es nuestro confidente y el odio es nuestro mejor aliado. Empesamos con sueños y al finalizar es una pesadilla terminamos hasta hacerles daño a las personas que queremos todo es un fango donde damos lo que resivimos somos como una tortuga con ganas de salir corriendo pero el peso que llevamos por nuestra cobardia nos obliga a estar en un mismo lugar). ${ }^{27}$ (It's the point when the person [starts] to feel ashamed of herself, [comes to] hurt herself, the feelings of violence is a vicious circle where we start to talk out of fear and we bury ourselves until we are silenced it's the only refuge we've found grief is our best friend remorse is our confidant and hate is our closest ally We start with dreams and the result is a nightmare we end up hurting those we love everything is a mudpit where we give what we receive we are like a turtle wanting to run away but the weight we carry from our cowardice obligates us to stay in the same place) (Sentimientos Ocultos, El Cilencio and El Guapo, Participatory Writing Workshop, November 3, 2010).

Consecuencias y secuelas que nos deja la violencia (Consequences and traces that violence leaves with us)

Eridas profundas que nunca sana jente con buenas intenciones que todos sus ideales estan enterados en cementerios fueron personas, familias que quisieron hablar pero sus voces fueron apagadas lo unico que nos queda por hacer es unirnos todos y luchar por un mundo mejor o callar para que la violencia otra vez gane su partido no se necesita nil ni2 ni3 personas se nesesita de un mundo de personas de un conjunto de valor miles de libras de esperanzas kilos de gallardia centenares de ideales y millones de toneladas de armonia para poder devolver la confianza y la esperanza a

${ }^{27}$ Grammatical and other errors in the original text have been preserved. 
un mundo lleno de miedo sin esperanzas de volver a sus lugares natales sin pedir que olviden su pasado sino que se basen de esto para construir un mañana mejor .... ${ }^{28}$ (Deep wounds that never heal good intentioned people whose ideals are buried in cemeteries they were people, families that wanted to speak but whose voices were silenced the only thing that's left to do is for us all to unite and fight for a better world or be silent so that violence wins its game again we don't need 1 or 2 or 3 people we need a world of people from a set of values thousands of pounds of hope ...kilos... of bravery hundreds of ideals and millions of tons of harmony to be able to [...reinstate...] trust and hope into a world full of fear without hope of returning to their birthplaces without asking that they forget their past but rather that they use it as a foundation to build a brighter tomorrow) (Sentimientos Ocultos, El Cilencio and El Guapo, Participatory Writing Workshop, November 3, 2010).

Para Nosotras... ¿Violencia es? (For Us...Violence is?)

$\rightarrow$ Hambre $\rightarrow$ Pobreza $\rightarrow$ Desempleo $\rightarrow$ Miseria $\rightarrow$ Enfermedad

$\rightarrow$ Secuestro $\rightarrow$ Muerte $\rightarrow$ Trafico de Personas $\rightarrow$ Explotación

$\rightarrow$ Miedo $\rightarrow$ Intolerancia $\rightarrow$ Maltrato $\rightarrow$ Discriminación $\rightarrow$ Frio

$\rightarrow$ GARAVITO 'Violador de Niños ${ }^{, 29}$

$\rightarrow$ Estres $\rightarrow$ Habuso Sexual $\rightarrow$ Explotación Sexual

$\rightarrow$ Rabia al no poder hacer uno nada ante lo que pasa

$\rightarrow$ Impotencia $\rightarrow$ Ganas de Morirse

$\rightarrow$ Sucio $\rightarrow$ Vomitos $\rightarrow$ Dolor $^{30}$

${ }^{28}$ Grammatical and other errors in the original text have been preserved.

${ }^{29}$ Luis Alfredo Garavito is a convicted mass rape-murderer of children who "...confessed to killing at least 140 boys between ages 8 and 16 over a five-year period...[the police] said Mr. Garavito, a 42-year-old drifter, would befriend the children and take them on long walks until they tired. Then he would tie them up with nylon rope, slit their throats or behead them, and bury their bodies" (Rohter 1999, 1).

${ }^{30}$ Grammatical and other errors in the original text have been preserved. 
$\rightarrow$ Hunger $\rightarrow$ Poverty $\rightarrow$ Unemployment $\rightarrow$ Misery $\rightarrow$ Disease

$\rightarrow$ Kidnapping $\rightarrow$ Death $\rightarrow$ Human Trafficking $\rightarrow$ Exploitation

$\rightarrow$ Fear $\rightarrow$ Intolerance $\rightarrow$ Mistreatment $\rightarrow$ Discrimination $\rightarrow$ Cold

$\rightarrow$ GARAVITO 'Child rapist'

$\rightarrow$ Stress $\rightarrow$ Sexual Abuse $\rightarrow$ Sexual Exploitation

$\rightarrow$ Rage at not being able to do anything about what happens

$\rightarrow$ Impotence $\rightarrow$ Wanting to die

$\rightarrow$ Dirty $\rightarrow$ Vomiting $\rightarrow$ Pain

As the girls were writing during our weekly workshop in my (maybe too)

comfortable high-rise apartment in the hills, we sat on the terrace and everything for a moment seemed peaceful. The sun came out, which in Bogotá's plateau climate is rare; we chatted, drank coffee with Ducal (a food brand) crackers, and looked out and into the mountains. El Cilencio counted the stars in the Christmas light display positioned in the hills surrounding Monserrate ${ }^{31}$ and Sentimientos Ocultos whistled down at the boys playing soccer below. Then we started to talk about violence. The mood and body language shift in the group was almost immediate. Just as they worked out the last sentences of the narrative 'Sentimientos de Violencia,' El Guapo abruptly pushed back her chair and ran inside to the bathroom. Sounds of forceful dry heaving pierced the air for at least five minutes. A much paler Guapo stumbled back to the worktable, inhaled dramatically, and said, "Add vomitos (the sensation and/or act of vomiting) to the word

${ }^{31}$ Located 3,152 meters above sea level, Monserrate is the most frequently visited tourist destination in Bogotá (www.cerromonserrate.com). A four-minute gondola ride has you to the top of the mountain that overlooks the more than eight million inhabitant urban sprawl of Bogotá and the untouched mountain landscape on the other side. 
list." Shortly thereafter, Sentimientos Ocultos, after losing interest in the soccer boys, directed her attention to the roof in order to avoid making eye contact with the group and to hide her tears as she talked about her family and mother in Chocó. It seemed as though our discussion of violence forced her to return to her body. She began to mention the discomfort she felt 'down below' and ran for a lime to extinguish the pain, which is an (ineffective and often damaging) street remedy for sexually transmitted infections (STIs) that the girls often use to put off the hospital visit. El Cilencio laughed (with sadness in her eyes) and said, "See...we feel it in our bodies." Memories of violence, for street girls, are physically held in particular private places. It was definitely a rough day for all of us. After the workshop we walked around the streets of el centro (Bogotá's central district) for almost three hours and hardly spoke - sometimes it helps to just walk it out. 
Figure 2.1: Textual Representation of Violence

$\mathrm{V}$ ivir atemorizados ocultos sin derecho a exprezar lo que ivimos o sentimos a diario. la falta de conciencia nos tiene...

$\mathrm{I}$ ntimidados con un gran indise de cobardia miedo ntolerancia, insensatez con falta de balentia o de...

rgullo mismo dispuestos a luchar por un ideal ajeno por falta de hombria capases de callar. Una...

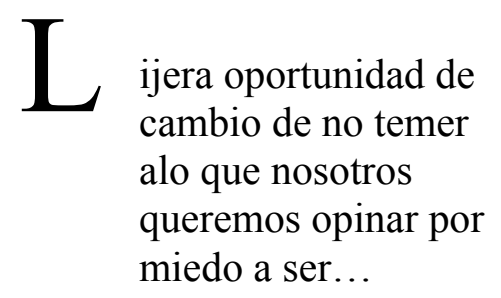
mor armonia cinceridad
A realidad por todo quello que nos prometen y no nos cumplen...

T ndignación tristesa por ser victimas de una violencia ncapaz de buscar un buen resultado nosotros solo
(queremos...
apaces de pazar por ensima de cualkier sueño para onseguir sus objetivos...

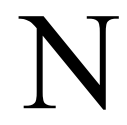

adie nos tiene en cuenta solo obtenemos migajas y uestros conosimientos se quedan en fantasia son...

\section{E xcluidos o peor a terminar en fozas comunes el nsierro en que vivimos es algo tenas...}

*Written and designed by Sentimientos Ocultos, El Cilencio, and El Guapo. * Grammatical and other errors in the original text have been preserved. 


\section{Watching Violence from Above}

It was our second day of the 'Violence and Words' workshop. As the girls worked on their visual representation of violence (see Image 2.1 above), we heard a huge explosion. The girls went running to the terrace on the second floor. La Universidad Distrital theater and arts campus is behind my high-rise apartment. Students with black face masks and backpacks were running circles around my building as they plan for and start the protest throwing papa bombas que tienen explosivos por dentro (potato bombs that have explosives inside) at the police as they line up. Two military tanks arrive and between 10 to 15 armed anti-motines (anti-riot police force) were throwing tear gas and spraying powerful strains of water over the protesters. The protesters used the trees in the hills to arm their papa bombas and dodge tear gas shots.

The girls seemed to be glued to the violence...for once they were not in it or at the receiving end. They were just observers watching from above. At every moment between bombs and tear gas I ran downstairs to write my reactions and the girls yelled at me to return to the show: "Amy! Venga ...vea...! (Amy! Come...look...!)" It was quite an interesting scenario. What do they feel watching from above? How do they categorize this type of violence?

As sounds of sirens filled the air and tear gas seeped into the apartment, Sentimientos Ocultos observed that it is "...una guerra que se vive en Colombia...una guerra que no tiene fin ... una guerra absurda (A war that is lived in Colombia... a war that has no end...an absurd war...)" (Sentimientos Ocultos, Participatory Writing Workshop, September 1, 2010). In response to her friend's comment, El Cilencio says: 
...lo que estamos haciendo es vivir una gerra ajena donde no sabemos por que o por quien luchamos. No paramos un minuto para mirar atras y preguntarnos, '¿sera que la jente esta de acuerdo con lo que hacemos?' ...no es justo que por una politica creada por 'x o y' personas tengamos que pagar jente que no tuvimos participacion en esto...solo quedan en promesas hasta 'cuando vamos a tener igualdad de derecho' '¿hasta cuando va a existir el miedo?'... (...What we are doing is living a war that doesn't involve us where we don't know why or for whom we are fighting. We don't stop a moment...to look back and ask ourselves, 'Do the people agree with what we are doing?'...it's not fair that for politics run by ' $x$ or $y$ ' persons those of us who are not participating have to pay...they just make promises... 'When are we going to have equal rights?' 'How long is the fear going to last?'...) (El Cilencio, Participatory Writing Workshop, September 1, 2010). ${ }^{32}$

Blow vs. Lives

"Un kilo de polvo vale mas q' 10 Vidas Humanas...(One kilo[gram] of blow is worth more than 10 Human Lives)" (El Cilencio, Participatory Writing Workshop, September 1, 2010). ${ }^{33}$

As stated by Colombian economist Francisco Thoumi, Colombia's development is paradoxical. "[W]hile the physical standard of living has improved [because of the drug trade], the country has actually become less livable" (Thoumi 1995, 3). Colombia is

\footnotetext{
${ }^{32}$ Grammatical and other errors in the original text have been preserved.

${ }^{33}$ Grammatical and other errors in the original text have been preserved.
} 
often characterized as a country in a constant state of crisis, conflict, and rapid transformation. One day it is safe to travel throughout Cundinamarca by bus (according to the U.S State Department) and the next bus travel is forbidden for all U.S. Embassy employees (including Fulbright scholars). I remember waking up one morning in August of 2010, brewing my fresh cup of Colombian coffee and feeling almost peaceful as I watched the mist rise off the Andes Mountains. Less than twenty blocks away was a completely different story... a car bomb had been set off beside the Davivienda bank headquarters and Bogotá again went into crisis mode. La Séptima (one of the main avenues) was shut down and north-south traffic came to a stand still affecting movements of hundreds of thousands of commuters from Ciudad Bolivar to Sedritos. Who was responsible? It is difficult to determine. Revolutionary Armed Forces of Colombia (FARC) demonstrating their discontent with the recently assumed Santos regime? Paramilitary staging as the FARC? When I turned my phone on I had numerous missed calls and messages from the Fulbright office frantically determining that no one was hurt, and from my Mom who had seen the news all the way in Connecticut before I even had a clue. I was too focused on catching up with fieldnotes about the other urban war surrounding me daily in the streets.

These events prompted me start thinking of other contradictions I have seen or heard throughout my time and travels in Colombia. In a small fishing community outside of Buenaventura (Colombia's main port city on the pacific coast), imagine two AfroColombian brothers, in the 1970s sharing an ice-cold Poker (beer brand) after a long days work. One moment chuckling along with the radio and in the next machete to throat over a Conservative vs. Liberal party argument. Colombian urban youth today, many of 
whom are daughters or sons or rural-to-urban migrants, mock such stories from el campo (rural areas) told by their parents and in the next moment blindly throw themselves into potato bomb and grenade flinging protests on the urban campus of 'La Distrital' (city district university). Contradiction, polarization, and raging inequalities run deeply throughout Colombian society and are associated with the rapid social, economic and political transformations that have occurred in Colombia over the last fifty years.

The emergence of the drug trade in the 1960s must be considered within this paradoxical and incoherent national context. Melo (1998) highlights the following moments in the evolution of the drug trade and its political context in Colombia: 1) the small-scale cultivation of marijuana (targeting a U.S. market) in the 1960s expanding until the 1980s and establishing the logistical and business framework for the refinement and exporting of cocaine; 2) the emergence of the cocaine cartels including the formation of the main groups of exporters between 1974 and $1978^{34}$ - this period of trafficking peaked in 1982 and accounted for $10 \%$ to $25 \%$ of Colombia's total exports; 3 ) the period of violence in the mid -1980 s as "...the drug 'barons' [including the rise of traffickers such as the Ochoas, Escobar, Lehder and Santacruz] consolidated their fortunes, acquired political power and were able to buy their own judicial impunity or obtain it by force" (Melo 1998, 70). The number of killings and violence against government officials increased until 1991 as the risk of extradition and large-scale government operations to

\footnotetext{
${ }^{34}$ The following groups, cities, and actors dominated the industry during this period: “....in Medellín two or three large cartels; two major cartels were created in Cali, led by José Santacruz and the Rodríguez Orejuela brothers, together with a number of minor organizations; the groups from the north of Valle; Carlos Lehder's operation; the coastal groups and those from the Eastern Plains; Gonzalo Rodríguez Gacha's group in the central-east of Colombia; and the organisations in southern Colombia" (Melo 1998, 69).
} 
destroy central laboratories and confiscate other assets placed pressure on traffickers; 4) a shift in drug control policy attempting “...to secure the voluntary surrender of traffickers to the Colombian judicial system...including a series of legal reforms [implemented in 1990 by President César Gaviria] guaranteeing those drug traffickers who surrendered and confessed to their crimes immunity from extradition and reduced sentencing" (ibid, 73-74). The delay in Escobar's surrender and his subsequent escape from prison in 1992 contributed to the escalating confrontation between traffickers and the government and the increase in associated kidnappings and killings. Ultimately, the 1991 Constitution, which, in addition to recognizing the rights of "....different ethnic and national groups... and professed to be a kind of peace treaty between all Colombians, also banned extradition. Thus, the traffickers' ultimate demand was met: the only judicial sanction from which they had anything to fear was removed from the legal order..." (Melo 1998, 76); 5) The accusation of President Ernesto Samper's involvement with the Cali cartel before even assuming the presidency in 1994, the Congressional investigation surrounding the narcocassettes suggesting a connection between the cartel and Samper's election campaign, and the resulting impact on Colombia's image in the international arena greatly strained US-Colombia relations and set the tone for the conditions and direction of foreign aid.

The gradual de-legitimization of the Colombian state and its judicial system coupled with the country's long history of political violence constitute the basis and means of maintaining what is referred to as the 'Colombian Advantage.' Other factors have also been suggested to contribute to Colombia's advantage as the hub of illegal drug production, including the history of contraband trade (e.g., emeralds, coffee, livestock 
into Venezuela and Ecuador) establishing the link with smugglers across borders, the country's isolated geographies, and the emigrant network of Colombians legally or illegally in the United States (Thoumi 1994, 88).

After his own experience of battling the Colombian state and surviving multiple death threats from state officials, Timothy Ross, former journalist and war correspondent in Colombia and other parts of Latin America, provides the following commentary on Colombian politics and corruption:

"Colombian politics now is largely based on struggle for and control of drug-trafficking and land holding, which go together, both as bases of power and headquarters of private armies and for investing in and laundering money through cattle and horse breeding and agricultural products such as palm oil. The palm oil industry has been taken over by Paramilitary and drug-traffickers massively in the Northwest. The state land reform programs over the past thirty years, supposed to distribute land to property-less peasant farmers, has actually concentrated land holdings, in many recent cases, giving titles to accused or convicted drugtraffickers and paramilitary commanders. State agricultural subsidies have also been found in recent investigations [2009-2010] to be diverted from the intended beneficiaries of small landholders to major agro-industrial complexes with shareholders including convicted traffickers ${ }^{35} \ldots$ power is

\footnotetext{
${ }^{35}$ At the time of writing - this case is on-going and involves criminal charges against a former Vice-Minister of Agriculture - 'Juan Camilo Salazar Rueda' and the former director of Agrarian Reform Institute 'Incoder' go to court December $20^{\text {th }}-$ Secretary
} 
for spoils not for public benefit and state coffers are regularly

looted...while for more than 15 years between at least a quarter and sometimes more than half of all Congressmen and Senators can be linked to drug-trafficking investigations and often as many as 10 or 12 are imprisoned..." (Timothy Ross, former journalist - ABC News and others - Director of Fundación Social Fenix, four-decade resident of Bogotá).

While the purpose of this chapter is to re-frame popular conceptions of Colombia, it is difficult to uproot the nation's characterization as a 'narco-democracy' when "[e]very day Colombians see on the news how Congress, mayors from remote regions, the judicial system or the bureaucracy are penetrated, influenced and directed by the 'narcos'” (Melo 1998, 63).

During my fieldwork and time in Bogotá between November of 2008 and August of 2011, numerous corruption scandals were exposed within state entities including the Departamento Adminstrativo de Seguridad (the State Department of Security), Ministerio de Agricultura (Ministry of Agriculture), la Fiscalía (State Prosecutor's Office), the National Narcotics Directorate, Congress, and Senate. These scandals demonstrate the instability and unreliability of governmental entities and overall functionality of the Colombia state.

Even as an insider (part of deviant street networks and interwined within Bogotá smuggler-user circles), El Cilencio has a similar conception of the drug trade and those involved. She notes that:

General of the Ministry, the head of the legal office, the head of the rural development office, and two advisers of the minister also go to court (El Tiempo, October 28, 2010). 
“...Todo es una mafia un mundo de mentira desde los favorecidos [...] son governantes, precidentes, etc...los principales ciudades de narcotrafico y grupos al margen de la ley son...

Cali...

Medellín...

Villavicencio...

Estas ciudades abastecen al resto del pais...

(Everything is a mafia a world of lies from the favored [...] they are governors, presidents, etc....the principal cities of narco-trafficking and groups on the margin of the law are....

Cali...

Medellín

Villavicencio...

These cities supply the rest of the country)"

(El Cilencio, Participatory Writing Workshop, September 1, 2010). ${ }^{36}$

As noted by El Cilencio, the drug trade in Colombia is centered on regional powers in the areas where traffickers have achieved territorial domination. As in the case of some Atlantic Coastal regions where "...the power of the state has been more privatized in the hands of political-patrimonial elites, ...the penetration of narcotraffickers was easier and resistance by the state was weaker. The main source of traditional power, which rested on the monopolistic ownership of the land, changed hands when new narco-landowners emerged in many areas of the country" (Reyes 1994, 124).

\footnotetext{
${ }^{36}$ Textual formatting and grammatical and other errors in the original text have been preserved.
} 
In the case of Cali and Medellín, traffickers “....achieved serious transformations in the composition of urban elites and their social relation with popular groups. The traditional entrepreneurial elites were faced with unequal competition from narcotraffickers and, in both cities, a group of narcos invested their capital and pooled their resources to take advantage of the profit-making associated with narcotraffic...the generous irrigation of money, employed to buy existing criminal manpower, generalized the practice of hiring professionals to settle accounts or eliminate obstacles to the drug business by police or judges. Criminal bands multiplied and the rate of homicides shot up in the two cities during the 1980s" (Reyes 1994, 124).

These divisive roots of corruption and conflict are evident in current patterns of segregation, both geographically and socially. These divisions are notable geographically, in conflict between regions, as well as across the system of socioeconomic stratification. They have led to greater social and geographic inequality; i.e., both in the lives of street girls and in the concentration of wealth and government investment in el triángulo de oro (the golden triangle) including the cities of Cali, Medellín, and Bogotá (See Map 1.1).

\section{Moving Beyond Violence}

In both chapters four and five, street girls' everyday experiences of social and spatial inequality, violence and exclusion are illustrated through text and visualized through cartographic and photographic images providing a window into their world. Chapter six describes street girls' participation in the 'action' components of the YPAR project, including our Bogotá-based street outreach program called Hip-Hop para el Cambio (Hip-Hop for Change). Our research team developed this project as an 
alternative approach to collective knowledge production that mobilizes marginalized youth in the roughest streets of the city to re-claim and re-write their urban experience through artistic expression. As a means of working against and coping with street girls' everyday experiences of violence and exclusion, the concluding chapter presents the graffiti and lyrics produced by street girls and projected throughout the popular urban imaginary in multiple spaces ${ }^{37}$ during our YPAR team presentations in institutional and public spaces.

${ }^{37}$ The YPAR team has participated in academic presentations (including the regional Geography conference), governmental policy meetings and urban planning working groups, U.S. Embassy social justice events, and as guest speakers on a hip-hop radio show in Bogotá. 
III. Young People's Geographies of Exclusion and Vision of the City

Introduction: From Crisis of Representation to Participation

This chapter presents a synthesis of the three principal bodies of literature underpinning the theoretical and methodological basis of this dissertation: geographies of exclusion, children's geographies, and feminist visualizations of urban space. This chapter provides the theoretical foundation for the following empirical chapters illustrating street girls' geographies of exclusion in Bogotá (chapter four) and ethically representing street girls' vision of their everyday lives and exclusion within the city (chapter five). Addressing intellectual gaps within the subfields of children's geographies and aiming to bridge qualitative human geography and GIS methods, this chapter argues for a re-construction of notions of young people, maps, and photographs in the discipline of Geography and the place and role of youth and alternative visual methods in research.

During my first day in la Mariposa, I tagged behind Timothy as he introduced me to street girls that work in the plaza and throughout the streets of Santa Fé. I was quite nervous and did not know what to say. "Hola Angélica! ¿Qué cuentas? Te presento a una amiga que va a trabajar en el centro con niñas... Es una compañera de confianza así que cuentas con ella...(Hi Angelica! What's new? This is a friend who's going to work in the center with girls. She is a trusted colleague...you can count on her)." During this introduction process, Timothy helped me enter into the world of street girls, prostitution, and drugs in Bogotá by presenting me to key actors in the streets as an ally and answering the initial questions that emerge in first encounters between 'the researcher' and 'the researched.' Who am I? Who are you? Who is she? How will our distinct identities 
interact in order to build a youth-based participatory action research (YPAR) team of researchers? These questions are definitely present in fieldnotes from my first days in the streets. Who am I? How do they (street girls) see me? At first, my gringa (North American) accent placed me as an outsider but my Colombian appearance made me a more curious figure (she looks like us but definitely does not sound it). My fieldnotes are splotched with similar questions. Who is she? Where does she come from (her appearance and accent seemingly from the Pacific coastal region)? What do her rigid body language and focus on my wristwatch mean? Will I be able to overcome the immense distance between us?

The construction of research relations begins with these questions regarding the positionalities and identities of all research actors. Incorporating a moment in the research process to consider these questions and what they mean for the construction of an ethical and participatory research program that represents 'subjects' not solely from the perspective of the 'researcher' but from those of the 'researched' is an important step (Pile 2010; Crang and Cook 2007; Tuhiwai Smith 1999; Wolf 1996; Behar 1996; Motzafi-Haller 1997). When considering the complexity of the social relations constituting the research process, I join Crang in his weariness of “...work that divides positionality formulaically into being insiders (good but impossible) and outsiders (bad but inevitable)" (Crang 2003, 496). With similar critical reflection, Narayan writes “... as someone who bears the label of 'native' anthropologist and yet squirms uncomfortably under this essentializing tag" (Narayan 1993, 672). She further argues that "[i]nstead of the paradigm emphasizing a dichotomy between outsider/insider or observer/observed, I propose that at this historical moment we might more profitably view each anthropologist 
in terms of shifting identifications amid a field of interpenetrating communities and power relations" (Narayan 1993, 671). Rather than thinking in dualisms that forge distance, impose positionalities and roles, and define social relations before they are developed in the field, I suggest framing research relations in terms of collaboration and collective work amongst members of a research team. Contrary to the traditional ethnographic research and writing process, it is of utmost importance to begin the process of reflection surrounding identities and representation at the outset and to continue throughout the research process. In a conversation with anthropologist Michael Taussig regarding my research, I made a reference to my 'data chapters,' the 'data collection phase,' and 'data processing' as we discussed possible strategies for organizing and presenting information in my writing. He said (paraphrased), “...well, data, I wouldn't even call it that, but perhaps organize your thoughts, even the formalized discussions required by your committee, around one or two girls' stories throughout each chapter" (Personal Interview, October 30, 2010). This made me stop and think. Even sticking to conventional language within academia objectifies our work with communities and places them as objects of analysis rather than subjects who embody lived experiences and narratives.

As qualitative researchers we therefore face the challenge that “...simply listening to, giving voice to and representing the silenced is not enough" (Crang 2002, 648; see also Crang 2005). My methodological approach, informed by YPAR, care ethics, and qualitative research methods emphasizing the verbal, visual, and textual and how they relate to one another in the process of knowledge construction, presents ways to address and move beyond this dilemma of representation and the tendency to structure the 
research process and research relations in hierarchical and dichotomous terms. The first step in addressing the sorts of dilemmas of representation I identify above is to construct a more inclusive and interconnected research process that includes the voices and participation of those traditionally excluded from academic research programs. By employing a YPAR approach, the participation of street girls in this research program was developed through a "...process for personal and social transformation; in other words, as a process of 'opening' our own eyes and seeing the world through 'different eyes,' coupled with a desire to open others' eyes" (Cahill et al. 2008b, 90; Cahill 2007a; Cahill et al. 2008a). The concept of employing not only a polyvocal approach to constructing knowledge but also an approach grounded in a reflexive, multi-layered youth vision will be discussed throughout this chapter as the basis for the manner in which street girls represent themselves and their city in the following empirical chapters. Geographies of Exclusion

The human landscape can be read as a landscape of exclusion...to get beyond the myths which secure capitalist hegemony, to expose oppressive practices, it is necessary to examine the assumptions about inclusion and exclusion which are implicit in the design of spaces and places. The simple questions we should be asking are: who are places for, whom do they exclude, and how are these prohibitions maintained in practice? Apart from examining legal systems and the practices of social control agencies, explanations of exclusion require an account of barriers, prohibitions and constraints on activities from the point of view of the excluded. I would agree with Jane Flax, however, that there is no single 
oppressive reality, no single structure obscured by the images of the dominant culture, to uncover ... One part of the problem, then, is to identify forms of socio-spatial exclusion as they are experienced and articulated by the subject groups (Sibley 1995a, ix - x).

As written and illustrated through the voices of street girls, this dissertation takes the point of view of the excluded as its point of departure. How do street girls experience socio-spatial exclusion? From where and by whom are they excluded? How does this impact their everyday lives and geographies? Everywhere street girls walk they are watched by passersby. Even when they come for writing workshops at my house - the guard looks at us as if we are running an illegal operation out of my apartment. And the neighbors have started to notice as well. Street girls' geographies are bound to very particular and limited spaces in the center of Bogotá. Angélica walks with pride and with libertad (freedom) in la Mariposa, yet the moment we reach la Séptima and above (approaching Universidad de los Andes) her demeanor changes. Her shoulders begin to slouch, her smile fades... she stops cracking jokes and opts to remain silent and stare at the sidewalk. I stop at an internet café to make a photocopy and she chooses to stay outside. Angelica's experience provides a grounded illustration of the manner in which the stereotyping of people and places are connected (Sibley 1995b). As Angélica crosses the imaginary but very real boundary between deviancy and normalcy in the city, her growing feelings of exclusion and rejection demonstrate how spatial boundaries in Bogotá are performed, and how they can also be conceived as moral boundaries. Angélica's presence in the street of Bogotá thus represents the boundary within the public urban imaginary - an imaginary which she, too, has internalized - between right and 
wrong, between the pure, 'good' childhood and those children who are deemed as 'out of place' and as transgressing societal expectations about the place and behavior of girls in the city.

These moments and spaces of exclusion take place in various pockets of the urban environment. "Simplemente...no me gusta viajar en Transmilenio... ¿PARA QUE? ¿Para que... me miren feo...me empujen para hacer mas espacio para sus hijos bellos...no me rebajen el pasaje cuando no tengo [como lo hacen en bus] ... y los que no andan bien vestidos no les vendan la tarjeta? Entonces...tanto transmilenio ¿para que? No, gracias...por mi tomo bus o camino (I simply do not like traveling in Transmilenio...FOR WHAT? So that people look at me funny...push me to make space for their beautiful children...don't let me on when I don't have the money to pay the full ticket [like the buses do]... and so they don't sell a ticket to those not dressed well...So...so much Transmilenio for what? No thank you...for me...I take the bus or walk)" (El Guapo, Participatory Writing Workshop, January, 20 2011). Public transportation is one way of exercising one's mobility throughout the city and breaking free from the barbed wires of one's exclusion (Pred 2004). Angélica's sentiments regarding public transportation demonstrate yet another way in which street girls' geographies are limited to the few blocks of the city in which they are accepted. The tendency to avoid violent spaces of rechazo (rejection) is a contributing factor to street girls' exclusion within the city. Some might ask, if I can access the basics of what I need here in el barrio (neighborhood), why venture to spaces of discomfort where I do not fit in and am rejected? 
Children's geographers have explored the connections between homelessness and mobility and the sites of belonging and exclusion in the spatial lives of street youth in various contexts (Beazley 1998, 2000, 2002, 2003, 2004; Gough and Franch 2005; Van Blerk 2005). In particular, Beazley found that in resistance to “...the alienation they experience every day," street girls in Yogyakarta, Indonesia carved out their own space of refuge in a city park "...to which they can retreat if they have had enough of the outside male world" (Beazley 2002, 1675). Street girls' construction of their own spaces of group identification and cohesion and resistance to the multi-faceted discrimination and marginalization from mainstream urban society and space is part of the broader struggle of youth to challenge the exclusionary discourses and practices that limit their mobilities and autonomy in the city.

My research takes this notion of youth action and struggle as a point of departure and works to empower marginalized urban youth to create "...their own complex systems of inclusion and belonging..." (Vanderbeck and Morse Dunkley 2004, 177). My research also builds on the work of children's geographers by contributing new “... 'inclusive' methods... which allow young people greater latitude to express their views, represent their lives, and...to frame research questions and shape research agendas" (ibid). YPAR, as a method and ethics underpinning research with young people, provides a safe and collaborative social space in which young urban youth can begin this process of re-presenting their city and their limited mobility within it. The employment of a YPAR approach also facilitates the construction of a space for the research team to reflect upon the ways in which street girls' mobilities in Bogotá are potentially seen as a "threat to normality" (Cresswell 2001, 15). Thus, the mobilities of street girls are 
“...produced and given meaning within relations of power" and the spatial data from our project corresponding to these mobilities must be considered within their power-laden context. Youth research actors in our project therefore used the participatory and actiondriven elements of YPAR to negotiate, analyze, and resist the relationships of power embedded within their urban environment. For example, the objective of the participatory mapping methodology was not only to map street girls' geographies of exclusion but rather to place street girls' limited spatial reality within its political and social context through interviews and group analysis. Beyond identifying the spaces in which mobility is constrained, analysis must include questions such as, "[W]ho moves? How do they move? How do particular forms of mobility become meaningful? What other movements are enabled or constrained in the process? Who benefits from this movement" (ibid, 333; see also Cresswell 1999). For street girls in Bogotá, police raids and urban improvement efforts largely limit their mobilities and often force movement in and between public spaces in the city. In this case, mobility “.... is as much about meaning as it is about mappable and calculable movement. It is an ethical and political issue as much as a utilitarian and practical one" (Cresswell 2010, 3). While recent geographic research in Kampala and Recife has explored the impact of the regulation of urban spaces on street youth, the manner in which this forced movement is entangled with meaning and power has not been represented through the eyes of street youth (ibid, 4; Van Blerk 2005; Gough and Franch 2005).

The constraint of street girls' mobilities is a two-way exclusionary process. They avoid spaces of rejection, and people in mainstream public spaces reject street girls to keep them from returning, thus demonstrating how these geographies of exclusion and 
rejection are products of one another. With respect to these ideas surrounding avoidance, rejection, and exclusion, it is helpful to ground these concepts in a more corporeal fashion considering that much of street girls' 'first contacts' of exclusion are in reaction to images of their exposed bodies, clothing, language/street slang, and the manner in which the larger urban society sees and hears street girls. The body (and its orifices) is therefore a place upon which multiple conceptions of self, boundaries, and defilement are constructed and imposed (Kristeva 1982; Douglas 1966; Pile 1996). The perceived filth and deviance of street girls “...is not a quality in itself, but it applies only to what relates to a boundary and, more particularly, represents the object jettisoned out of that boundary, its other side, a margin" (Kristeva 1982, 69). The bodies of street girls are therefore a reflection or 'mirror' of Bogotano society and its anxieties (Pile 1996, 187; Douglas 1966). The constant display of street girls' bodies and the overt exhibitions of sexuality and public negotiation of sexual transaction position street girls' bodies as morally unacceptable and therefore 'out-of-place' in the public domain. Furthermore, “[m]etaphorical references [in popular discourse] to such substances [including the representation of health dangers in street girls' vaginal fluids] invariably imply threats to order" (Cresswell 1997, 341). The urban landscape of Santa Fé, for example, is filled with brothel business cards as they are distributed to every male passerby, newsstand displays of titillating yellow press stories of cheaply available sex, and sex club promoters persistently inviting clients to strip joints and live sex shows. The sociospatial association of street girls as having threateningly seductive but defiled bodies and dangerous fluids contextualizes, therefore, the manner in which street girls are deemed as a repulsively filthy population. Corporeal waste, particularly menstrual blood and 
excrement “...or everything that is assimilated to them, from nail-parings to decay, represent - like a metaphor that would have become incarnate - the objective frailty of symbolic order...[e]xcrement and its equivalents (decay, infection, disease, corpse, etc.) stand for the danger to identity that comes from without: the ego threatened by the nonego, society threatened by its outside, life by death. Menstrual blood, on the contrary, stands for the danger issuing from within the identity (social or sexual); it threatens the relationship between the sexes within a social aggregate and, through internalization, the identity of each sex in the face of sexual difference" (Kristeva 1982, 70-71). Street girls, representing sexual danger, deviance and desire, instability of social categories and issues (i.e., child/adult; work/exploitation; male/female), delinquency, and repulsion, are thus positioned as abject beings, as “... 'opposed to $I$ ' ...[as] 'radically excluded' but ....always a presence" (Sibley 1995a, 8). The abjection of street girls therefore is a product of society's repulsion and rejection of their existence... of the desire to expel the abject...of the anxiety produced by the inability to completely distance society from its waste.

Beyond notions of filth and dirt as perceived in popular discourse and representations of street girls, this dissertation illustrates how their bodily experience of exclusion in the everyday is felt, is seen, is processed and thus imprinted in the minds of street girls. They thus choose not to expose their bodies to these exclusionary processes in mainstream city spaces but rather exhibit them in spaces where this is accepted and expected of them (in terms of their work and exploitation). The presence of young, female and transgender sex workers in Caracas Avenue (a main thoroughfare and Transmilenio route) creates a spatial and moral boundary in the heart of the center of Bogotá. Young, queer exposed bodies in brothels along Caracas Avenue demarcate 
normalcy from deviance in Santa Fé as the Transmilenio passes by and hundreds of thousands of commuters gaze into the brothels...this is the image of street girls that remains in the popular urban imaginary and produces feelings of abjection, repulsion and the desire to get far away from this distant, deviant Other.

The erection of boundaries in Bogotá, containing street girls within certain deviant spaces of drugs and prostitution and keeping them out of urban spaces of normalcy, reflect how the "...sense of border between self and other is echoed in both social and spatial boundaries" (Sibley 1995a, 32). The instability of the multiplex boundaries found in the center of Bogotá effect larger scale, state-sanctioned reactions to clean the urban or to purge the urban of filth - both purifying or eliminating the existence of its filthy, deviant street dwellers and its deviant, filthy spaces (the images and representations of which are inextricably linked in public discourse and perceptions). As Pred argues in his discussion of the renewal public space in Stockholm, these spaces, for urban planners and the majority of city dwellers, are 'unspeakable.' (Pred 2004). These spaces are a

“...constant presence that in one way or another bespeaks an absence, a silence, an invisibility...As that which is automatically remembered in place, recalled without reflection, put into action without recourse to words. As a matter of habit(us), as a habit-of-thought repertoire - always built up in practice on the ground, always triggered by specific sign(al)s in specific social settings, in specific spatial contexts...As all those past (geographical) histories that have been pushed beyond the horizon of collective memory because erased, made opaque, covered up, culturally 
reworked, radically reinvented, socially reconstructed and remythologized, given a new (would-be) hegemonic version, or otherwise removed from encounterable discourse...As that sited phenomenon that is so terribly attributed, so far beyond the norms of the acceptable, so gruesome or grotesque, so disgusting or distasteful, so repulsive or revolting, as to leave one speechless. In a word (or two), as the simply horrendous. Unspeakable spaces, then, as enmeshed in geographies of the taken-forgranted, the forgotten, the taboo-laden, the literally unsayable, the absolutely appalling...Spaces and geographies of consequence produced by way of specific situated practices, by way of variously scaled power relations and intersecting discursive networks" (Pred 2004, 147-149).

The desire to eliminate deviant, unspeakable spaces as a means of (re)presenting Bogotá as a clean, modern, city of progress is demonstrated in various cases of urban renewal in Bogotá. As Sibley notes, these spaces also represent, and are linked to the people found within them. In the case of Santa Fé and drug zones such as la $L$, the perceived 'erosion' of these spaces is linked to the image of the people that work and live within those spaces and (seemingly) contribute to its deterioration. As will be discussed in chapter five, multiple urban spaces occupied by street girls have been targeted for urban renewal. Chapter five will elaborate the condition of the five study sites and how boundary erection, enforcement and spatial purification are taking place in each space. Street girls' cartographies, narratives, and photography will visualize how these spatial purification processes have affected their everyday lives and spaces. 


\section{Children's Geographies and Young People as Researchers}

I now shift to a focus on the field praxis and methodologies employed by the YPAR team, in order to engage with and investigate the socio-spatial exclusion and everyday geographies of youth in the streets of Bogotá. This transition includes a discussion of the employment of the principles underpinning YPAR and care ethics as a means of developing an ethical, action-oriented, and caring research process with young people focused on the connections that exist between research actors rather than the differences that separate them. ${ }^{38}$

The young people that participated in the YPAR project faced several challenges because of their very categorization as 'youth,' 'young people,' 'children,' or 'teenagers.' Firstly, in terms of their formal participation in a research project, simply being a 'child' or minor required special procedures, both legally and ethically. The institutional framing of ethics in the federal Office of Human Research Protection (OHRP) Code of Federal Regulations (45 CFR 46) positions children as less-than (adults) and undeveloped human 'becomings,' rather than human beings capable of making informed decisions regarding their participation in research projects (Holloway and Valentine 2000a). This age-based hierarchy in the research process creates tensions between the operationalization of a legally compliant human subjects protocol (i.e., IRB requirements) for fieldwork, the competence of children to "affirmatively agree to

\footnotetext{
${ }^{38}$ Youth-based participatory action research refers to a research process driven by young people and based on the central PAR principles of interconnection, empathy, mutual familiarity, and social change and responsibility (Cahill 2007b; Cahill and Torre 2007; Cahill, Sultana and Pain 2007; Martin 2007; Butz 2008).
} 
participate in research"39 (45 CFR 46, 11), and the actual extent and conditions of their participation (Skelton 2008). Is research with children different from research with adults in this context of institutional ethics? How can adultist perspectives of children's geographies in general and research in particular be challenged? These questions have been raised by children's geographers and institutionally still remain unanswered (Punch 2002; Cope 2009). The disempowering discursive positioning of youth in 45 CFR 46 has not yet been challenged or even critiqued at the institutional level and Children's Geographies as a subfield has a long way to go before truly engaging with the voices of youth in the research process (but see Ritterbusch, 2012). ${ }^{40} \mathrm{~A}$ call for the inclusion of young people's voices in all aspects of the research process is not enough (Holt 2004). Research teams need to develop mechanisms to actually start doing so. As demonstrated in the structure and content of my dissertation, this is what our YPAR team has done.

Secondly, in the societal context of Bogotá, street girls' voices are often excluded from popular urban youth discourses as a result of the marginality of their existence and exclusion from youth social movements. The exclusion of street girls' voices is therefore

${ }^{39}$ The 'affirmative agreement,' of children in 45 CFR 46 is referred to as assent, which marks a distinction between the adult process of informed consent and child assent and thus competence and incompetence.

${ }^{40}$ I call this distinction between consent and assent discursive disempowerment not necessarily because the youth participants are aware of this age segregated measurement of decision-making capability but rather because the researcher (while obtaining IRB approval and learning the language necessary to obtain this approval to do research with children) actually internalizes these distinctions. Discursive disempowerment creates more distance and reinforces the separation between child/adult and researcher/participant rather than working to level the social field between these dichotomous categorizations that pre-define human relations and hierarchies in the research process (Ritterbusch forthcoming 2012). 
one instance in which the 'islanding' or protection of childhood has left a particular population of youth outside of the fortress (Gillis 2008). As Gillis notes, "children have been systematically excluded from the former mainlands of urban and suburban existence, especially the streets and other public spaces...We are therefore left with the question of what else contributes to the islanding of children. I want to suggest that islanding it is part of a larger cultural process, which has more to do with the ways adults, and especially adult males, think about, or rather think with, childhood...The islanding of children must be considered a creation of adults, a response to their own needs rather than those of children. Islanding children is a way that adults have developed to cherish their angels and exorcise their demons" (Gillis 2008, 316-317). This moral construction of the culture and bounds of childhood therefore positions public space as an environment that young people are "...too incompetent or too vulnerable to negotiate alone... [and] [h] anging around on street corners and larking about in public space become (deliberately and unintentionally) a form of resistance to adult power" (Valentine 2004, 83). I suggest that this adultist cultural process shaping the normative structure of childhood contributes to the exclusion of street youth from the island of childhood, mainstream society, and urban public spaces. Our YPAR approach is an effort to work against the exclusion of street youth and centralize their perspectives and participation in the research process.

Thirdly, we found that as a team, female and transgender street youth are not only the subject and content of the subfield of Children's Geographies, but rather the driving force, the leading actors, and those most capable of introducing children's geographers to the spatial world of youth in cities. Street youth are the gatekeepers of the city and to the hidden knowledge in places that others dare not go. A more profound understanding of 
street girls' unique knowledge of the city gives the terms 'street smarts' and 'street literacy' grounded meaning (Cahill 2000). Street youth are those who run the streets, who grant or deny passage, who name alleyways and know the micro-geography of the city better than most other city dwellers. Uncovering this 'semiotics of the streets' is an important element of understanding street girls' geographies (Matthews 2003). The lives of 'street' girls are inherently implicated in the spatial as they dominate the streets and are characterized as being of them. As pointed out in work with Brazilian street youth, they are 'at home' in the streets (Hecht 1998). Through the methodologies we developed together, street girls became my mentors and expert guides through deviant street networks as we worked to understand and examine the micro-geographies and semiotics underpinning their image of the streets. The graffiti-filled abandoned buildings are street girls' places of work and (drug) consumption, the night belongs to them, and the corners where they stand and wait for work are the same corners where compañeras have fallen to drive-by social cleansing shootings. Street girls' everyday lived experiences and movements therefore embody the manner in which the street is a site of discipline and deviance, illustrating how discourses surrounding street spaces are associated with failed urban planning, deviance and filth, and the moral tone of state-supported programs to keep youth 'off the streets.' (Cresswell 1998; Jacobs 1961).

Recognizing the competence of street youth as researchers representing both the 'urban' itself, and young urban people, is a necessary shift that must be taken in academic discourse in order to incorporate young people as important actors in the research process. However, recognition must also be accompanied by action in the field. The shift must take place both in discourse and action. Children's geographers have firmly 
argued for research relations that diminish disparities in power between researcher and participant (Morrow and Richards 1996; Thomas and O'Kane 1998; Young and Barrett 2001), give children control over the research process (Alderson 1995; Punch 2002; Alderson and Morrow 2004; Christensen 2004; Williamson et al. 2005; Morrow 2008; Skelton 2008; Sime 2008), facilitate a reporting-back process to all participants (Morrow and Richards 1996; Christensen and Prout 2002; Van Blerk and Ansell 2007; Hopkins 2008), and employ a child-focused methodology enabling participants to explore their subjectivities and ways of practicing space as young people (Van Beers 1996; Matthews et al. 1998; Beazley and Ennew 2006; Evans 2006; Cahill 2007b; Kesby 2007; Panelli et al. 2007; Thomson 2007).

These suggested practices, however, have not been operationalized in order to create more ethical research relations while actually in the field. The manner in which we speak about 'participants' in funding proposals, journal articles, and other academic publications also matters for action in the field. Instead of advocating for the use of visual methods in circumstances "where the actual physical presence of the researcher would have affected and distorted the situation" (Young and Barrett 2001, 391), why not refer to the benefit of visual methods for the integration of the research team during data analysis sessions? Academic discourse is researcher-driven and does not typically focus on group or participatory dynamics. The emphasis is on getting the information the researcher needs rather than using methods that foster collaborative research relations and generate data that enable youth to shape their own geographies. In fact, youth should be involved in every stage of the research process, not only the points in which the researcher determines they are needed. Academic discourse and methodological praxis 
within Children's Geographies continue to operate within the frame of the classic colonial encounter, taking knowledge from young people (even if in participatory ways) and analyzing it for them (Crang 2005). Young people are utilized to execute methods in spaces where adults do not have access and the information is then taken, analyzed and written-up by and from an adultist perspective. Rather than regarding the research process in terms of "...its absolute worthlessness to us" as described by Tuhiwai Smith regarding indigenous communities, young people should gain something (beyond formal participant compensation) from their engagement in research projects (Tuhiwai Smith 1999, 3). What is lacking is the shift in academic discourse surrounding the research process. The call to 'give children control over the research process' and 'give them a voice' still implies that it is the researcher giving young people this power and privilege (Williams et al. 2006, 89; see also Matthews and Limb 1999; Holt 2004). The idea, as we have done in the YPAR team, is to build a group dynamic in which the researcher shares this power over the direction of all research endeavors. Incorporation and integration is simply not enough. For youth to really shape the research process, it is the researchers that have to change the way we see and speak with and about participants. One step, as I have demonstrated in this dissertation, is by referring to team dynamics amongst research actors rather than participants. This implies that young people not only participate but rather construct research relations and information.

Grounding Care Ethics in Youth Participatory Action Research

In order to facilitate this shift in research relations and to build the team dynamic necessary for youth to participate as research actors in the YPAR process, I argue for the enactment of a care ethics practice in fieldwork as a means of bridging the disconnect 
between institutionally framed ethics and the principles guiding YPAR design. While care ethics “...begins from a relational social ontology, understanding our world in terms of the connections that bind us together," (Lawson 2007, 3-4) standard human subjects protection procedures often pull initial field relations in the opposite direction, establishing distance and difference between the researcher and research population through a temporally and spatially restrictive web of institutional categorizations and paperwork that pre-define participants' identities and role in the research project. A care ethics approach, in turn, calls for researchers "...to be attentive and responsive to our own locations within the circuits of power and privilege that connect our daily lives to those who are constructed as distant from us" (ibid, 7) and thus provides a starting point for building a team of research actors that together shape their relationship to and design of the project. Instead of making institutionally framed ethics 'fit' a particular research context, care ethics "looks at the specific sites and social relationships that produce the need for care and that frame the specific content of care ethics" (ibid, 3). I argue therefore that the enactment of a care ethics practice strengthens both the development of a YPAR program grounded in principles of mutuality, collaboration and interconnection, and the development of human subjects procedures appropriate for the social and spatial particularities of the research context.

Furthermore, I wish to suggest that, as critical children's geographers, we need to reflexively and even vulnerably observe (in the sense set forth in Behar 1996) how it is that we care about the research we are conducting and about the people touched by this process. For although discussions of care ethics in geography were initially situated in conventional sites of care-giving such as hospitals and elderly facilities (Conradson 2003; 
Popke 2006; Lawson 2007), caring is more broadly conceived as an attitude rather than a specific activity (Popke 2006, 506). What motivates or forms the basis for such attitudes $?^{41}$ Gradually revealing a window into these motivations to other research actors provides a means of constructing relationships of care in the field - for caring is not a one-way street. Discerning the multiple layers of our research agendas opens up more profound possibilities for our development of a 'sense for Others' (vis-à-vis a recognition of one Self) and unveils our positionality to the people we work with (Cloke 2002, 591; capitalization added for emphasis). The reflexivity of researchers is particularly important when conducting research with excluded, 'Othered' populations. The role of care in this process is to break down conventional social hierarchies in the research process by placing primacy on notions of interconnection, empathy, and mutual familiarity. As Lawson puts it, "care ethics begins with a social ontology of connection: foregrounding social relationships of mutuality and trust (rather than dependence). Care ethics understands all social relations as contextual, partial, attentive, responsive, and responsible....We see care not as a separate kind of relation, but as endemic to (potentially) all social relations that matter" (Lawson 2007, 3).

So what does care look like in fieldwork? The construction of relationships of care among research actors requires us to think outside of traditional ethnographic concepts such as immersion and participant observation that reproduce the dialectic of outsider-insider and enact pre-determined subject-object relationships of care. Each research encounter should, rather, ideally involve some form of exchange, whether of an

\footnotetext{
${ }^{41}$ Lawson notes that such reflections are 'valid' and even 'responsible' (Lawson 2007,
} 4). 
emotional or material resource. In my research, for example, passing out condoms, connecting girls with street-friendly hospital employees, and becoming a trusted ally within the NGO network in order to connect the girls with social services were effective starting points for relationship-building based in principles of community activism and outreach; however, the relationships that really mattered were those in which I offered pieces of myself and revealed my own vulnerabilities and everyday reality. Regardless of the particulars of the fieldwork in question, the objective is to create the sense of a "community of researchers" that share spaces, recognize boundaries and sensitivities, and exchange knowledge that will lead to mutual growth (Cahill 2007a). Actually sharing spaces or building “....spatially extensive connections of interdependence and mutuality..." in practice is complicated but has significantly enhanced my field relationships (Lawson 2007, 8). When research encounters occur in diverse contexts that encompass the socio-spatial networks of each research actor, notions of inside/outside gradually dissolve and are replaced by spatially identified concepts of 'us' and enactments of sharing. For example, by constantly shifting between institutional, street, and personal or home spaces, the girls and I have gotten to know each other in multiple contexts (i.e., participating in human rights awareness activities at local NGOs, having street corner conversations, celebrating birthdays, cooking meals together, etc.) in which each of us have different weaknesses, strengths and vulnerabilities. This dynamic makes it difficult for any research actor to dominate in the overall research context, and enables us to learn from one another and depend on others to generate comfort within and navigate through unfamiliar interactions and spaces. 
It is important, however, to recognize that building spaces and "[s]ocial relations of love, connection, mutuality, commitment, and so on are not idealized terrain, rather they are fraught with power relations that are worked out in specific contexts" (Lawson 2007, 4). When expressions of affect and emotional connection are uni-directional, relationships of dependence are formed and can have damaging consequences for all actors involved and for the research project itself. When Diana showed up at my apartment in the middle of the night with knife wounds, for example, I had to shift the focus of our activities back to institutional spaces and healthcare networks to reinforce that each shared space has both specific purposes and limitations. In turn, I also learned to navigate the shifting terrain between dependence and interdependence among research actors when counting solely on Diana to enter the more dangerous spaces of the prostitution and drug-dealing zone. When Diana disappeared for two weeks, I recognized the importance of maintaining more balanced and extensive social and spatial connections and access in the streets.

While the principles underpinning participatory action research often make it difficult to conceive of ethnographic, deeply immersed relations of care in the field as extending beyond the local and familiar, ${ }^{42}$ scholars have explored the possibilities of the spatial extensiveness of care and moved beyond the "...tendency to associate care with proximity" to the extension of care and responsibility across distance (Massey 2005, 193; Robinson 1999; Routledge 2003; Lawson 2007). So how far does our responsibility extend and "how far should we care" (Smith 1998; Popke 2006, 507)? For Lawson, in

\footnotetext{
${ }^{42}$ Burawoy et al. (2000) have also explored the extensiveness of ethnography or the possibilities of a global ethnography.
} 
part, “...our responsibility is to attend to grounded lives, politics and specific interrelations rather than abstract notions of our responsibilities to 'others"” and ultimately, "...our constructive response to care ethics is to responsibly learn and act" (Lawson 2007, 9). In terms of my own positionality that unevenly connects me to the girls, my response at this stage has been to build sustainable structures of caring in the streets that will continue to function without my presence or, (as demonstrated in the absence of Diana mentioned above), without a key informant.

I argue, therefore, that caring must be accompanied by constancy. Abandonment is fatal to the reproduction of care ethics. In practice, this means that despite the number of times I am left waiting on the corner for Diana and the moments when abusive clients (i.e., money for her next meal) take priority over street outreach, I am always there: absence and failed promises are tantamount to "you're not worth caring about" in the minds of youth who have been abandoned (by their parents and the state), de-valued and abused (by clients), and de-humanized (by those who dispose of their bodies without a second thought).

The reality, however, is that I will not always be literally there in the field. Therefore, I have worked with the girls to build networks of care in the streets that will continue to expand without my presence. Thus for the duration of my fieldwork, I worked to construct sustainable structures of caring through collaboration with a local non-profit organization (Fundación Social Fénix, http://www.fenix.org.uk/, accessed February 1,2011) to plan organized, embodied acts of reaching out to community actors and cultivating street-corner leadership. The efficacy of the Fénix Model of peer leader outreach lies in the collaborative and caring approach of its team members, female youth 
who, having lived and overcome experiences of neglect, exploitation, and abuse in the streets of Bogotá, are able to empathize with and empower other girls to envision and construct a pathway out of street-life. The objective is for this cycle of social change and activism to take root within the community and prevent repeated acts of abandonment from rupturing the process.

\section{Street Girls' Vision of the City}

Street girls' spaces in the city occupy a liminal space between public and private, home and street, work and 'play,' exclusion and belonging, and safe and unsafe. Street girls are thus experts in boundary jumping and re-defining spaces. Their everyday lives and geographies in the city demonstrate how

[b]oundaries of all types thus mark public space. Exclusion and inclusions in public space based on gender, race, and class frequently are theorized and often remarked upon. But to what degree is public space constructed around inclusions and exclusions based also on age? Are public spaces age specific? Are public spaces different for children, teens, adults, and the elderly? If, for example, children are excluded from a public space, then is it still public in the same sense? Or if public space is (or is seen as) inherently unsafe for minors, then does it remain much of a public space? Of course, this question is not much different from those raised above, but it does beg the question of the degree to which minors can fight for inclusive (or otherwise appropriate) public spaces. But the issue of safety raises another, perhaps deeper, question. And that is the question of what 
we imagine a good public life in a city to be (Mitchell 1996, 128; see also Valentine 1996).

These questions posed by Mitchell are addressed in the following data chapters through street girls' visions of public, private, and 'other' spaces in the city and their experiences of exclusion, belonging and action (through PAR) within these spaces. Street girls' cartography of the city demonstrates that these dichotomous categories used to make sense of urban space are insufficient when revealing the complex vision of Bogotá constructed by this Other population of young people. It is more useful, therefore, to "... attend more closely to the 'everyday' - to the multifarious relations between personal interaction, group action, the arrays of power, and the types of spaces involved in the everyday (and sometimes extraordinary) lives of people - we will understand a good deal more not only about how public spaces are formed and used, but also when they are" (Mitchell 1996, 129; see also Cope 1996). Street girls' vision of Bogotá embodies what is referred to as the 'urban everyday' for excluded young people in the city and facilitates the "...manipulation of urban space in order to provide room for living, all the way from parcels of actual land or protocols about who gets out of the way on the street to the smallest body movements that betray an expanded or contracted body image" (Amin and Thrift 2002, 297). The youth vision of the city includes not only cartographic representations of street girls' experience of place but also autophotographed images and textual representations constructed by street girls throughout the six research phases (Liggett 2003). Regarding the work of photographer Walker Evans, Liggett notes his distinction between the 'photographic' image and the 'photographed' images thus resisting objectification of the subject in the photograph 
(ibid, 121). The auto-photography component of the youth vision of the city presented in chapter five builds upon Ligget's notion photography and the role of the camera. She notes that "[t]ransparent use of the camera is understood in terms of explicit claims to represent the world, but at the same time this use implicitly reinforces preexisting cultural codes. In contrast with this, my interest here is in conceptualizing more active relations between photography and urban space. When used to make connections to the city, the camera is not an instrument of representation; it is a way of making space and attaching meanings. The camera becomes an active tool, not of representation, but of presentation...If photography is seen as the art of making (not taking) pictures, the possibility emerges for using it as a productive part of city life. From this perspective photographic images bring memory and experience together, attracting meanings in the process of stopping time and presenting a space...Take the camera out into the street, and the potential for unpredictable encounters with the city is built in...The 'arrest' that the camera makes allows the luxury of time outside instrumental time to be productive in the making of meaning. These are traits Lefebvre found crucial to "the right to the city"” (Liggett 2003, 119-120). In following chapters, street girls' maps, photographs, and narratives will bring the city to life as they see and experience it. The process of making urban space for young people employs multiple visual and textual methods that empower street girls' to claim their space within and right to city and demonstrate how "the invisible-made-visible in public space," if done so ethically, can effect positive changes in the everyday lives of excluded urban populations (Low 2005, 135; Low 2000). 


\section{Constructing Counter-maps of Urban Space}

The use of care ethics to drive participatory action research as elaborated in section two was essential for the collaborative construction of a youth vision of the city with street girls (chapter five) in order to project a visualization of their geographies of exclusion within the city and what their everyday urban geographies look like as a result of and in response to their exclusion. The maps illustrating this vision of street girls' worlds give us access to the Bogotá that street girls know and breathe, to the city that has turned its' back on them and to the spaces that constitute their social and spatial environment. Street girls, again, are inherently spatial. They run and define the city. Street girls' urban geographies as illustrated through our YPAR project surround four main data sources corresponding with the project's research phases: a general map of the city, seven zoomed maps portraying a closer look at the specific spaces on the base map, fieldnotes, symbol notes, and photographs of the girls' everyday spaces. Through the analysis of these materials, the YPAR team has constructed a youth-centered optic of the city and therefore a (street) youth vision of the city. The youth-centered optic encompasses the multiple meanings of the street, the ways in which street girls make sense of the implicit rules and social meanings inscribed in the urban environment (what Cahill refers to as their street literacy), and the projection of a street girl driven semiotics of the street (see Cahill 2000; Matthews, 2003; Cope 2008).

Our YPAR project worked with street girls to investigate the multiple meanings of maps for young people in the city and construct a participatory process that enabled maps to come to life for them and their compañeras (other street girls/peers). The approach to spatial knowledge production beginning with live bodies on street corners 
rather than from an objectifying, elevated vision enabled the YPAR team to develop a feminist visualization of the city. Rather than beginning with pre-designed base maps of the study sites that impose adultist, unfamiliar representations of urban space on research actors, street girls constructed their own base maps of the city, thus re-appropriating the “...power of GIS's visual technologies” through their counter-maps of Bogotá brought to life during the cognitive and activity mapping interviews (Kwan 2002a, 649). As found during phase one of the participatory mapping workshops (symbol construction), street girls' base maps of the city contained, for example, a tree marking lesbian gang territory, a wall that shoe-shiner street allies use as their office, a butterfly statue, a trusted brothel entrance, or a favored olla (drug zone - in street slang) marked by the color of the cocaine-base packaging - all symbols and places that make the base map a familiar space for street girls as they answer spatial interview questions and illustrate their movements throughout and perceptions of urban spaces on the map. Different from the disembodied official tourist map of Bogotá, street girls' maps visualize their city in “...embodied and situated practices" grounded in the social reality and spatialities constituting street life, drugs, and sex work (Kwan 2002a, 649; see also Gilbert and Masucci 2006; Knigge and Cope 2009). Street girls' grounded visualizations demonstrate the manner in which “...GIS is not fixed and given but is constantly remade through the politics of its use, critical histories of it, and the interrogation of concepts that underlay its design, data definition, collection, and analysis" (Pavlovskaya 2006, 2005). Instead of rejecting GIS as a positivistic methodology incompatible with feminist epistemologies, scholars have worked to redefine GIScience as a tool for critical geographers (Pavlovskaya 2006; Pavlovskaya and St. Martin 2007). Our YPAR project visualizing the everyday lives, 
socio-spatial context, and potential of empowering methodologies to effect positive changes in excluded urban communities highlights the common ground between feminist geography and geographic information science, rather than the divergent paths that past scholarship has used to argue for the incompatibility of the two research areas in Geography (McLafferty 2002; McLafferty 1995; Schuurman and Pratt 2002). While feminist methodologies have traditionally emphasized notions of reflexivity, multivocality, positionality, and difference as central praxis driving a feminist research program, GIS science and technologies have emphasized quantitative and technical approaches to knowledge construction detached from research subjects and projected from a "god's eye view" that erases the positionality and social, political and economic contexts of research subjects (Elwood 2006, 695; see also Kwan 2002b; Sharp 2005). Notions of participation, therefore, have been incorporated in order to increase public and community participation and access to GIS technologies thereby enabling “...people to become involved at a level that does not obfuscate their daily lives through maps and language drawn from instrumental, strategic logic. Rather, to be effective, the maps and language of PPGIS must communicate spatial stories that clarify and ultimately politicize the issues about which local people feel concern" (Aitken 2002, 364; see also Craig et al. 2002; Obermeyer 1998). The approach we have taken in the YPAR project hinges on community participation and participatory methodologies as the central elements underpinning knowledge construction thus employing a "GIS as qualitative method" approach rather than a "GIS with qualitative methods" approach (Elwood 2006, 702; see also Kwan and Knigge 2006; Cope and Elwood 2009). Street girls' cartography and construction of spatial information in the project is therefore derived from a "...much 
different understanding of the epistemologies and ontologies of maps in GIS, understanding maps more as cartographic texts that can be part of an interpretive production of meaning..." and introducing social theory concepts into GIScience (ibid). In our analysis and writing workshops with street girls, it was difficult at first for me to move away from the materiality of my conception of maps and mapping. When answering the questions, What is a map? What symbols organize our spatial representation of Bogotá?, the girls answered in terms of their feelings, perceptions and dreams for the future and in terms of what their current life maps lacked. Street girls' broader conceptualizations of maps are also reflected in local scholarship, as social cartography is described in more tangible terms that present methodologies and strategies for working with communities to envision cartographic representations of the past, present and future of community spaces (Carvajal 2005). Maps, therefore, are in our minds, and the city, as we hope to see it, is at our fingertips (through the maps we have made together).

In chapters four and five, the participatory mapping methodologies, construction of the project's spatial database, and participatory analysis of processed spatial data will be elaborated in order to demonstrate the manner in which our YPAR team has developed a grounded approach to 'straddling the fence' between human and feminist geography and geographic information science (O'Sullivan 2006, 783). 


\section{Entering Street Girls’ Worlds of Exclusion}

\section{Informed Consent}

The data presented in chapter four and five draw from deeply immersed geoethnographic research over a period of eighteen months throughout a six-phase multimethod research process. Thirty-three street girls participated in four phases (including exploratory interviews, auto-photography and place perception interviews, cognitive and activity mapping, and focus groups) while ten peer leaders participated in all six phases as part of the core youth-based participatory action research (YPAR) team. These peer leaders (also referred to in the text as 'principal' research actors) shaped the design of the four research phases in which all research actors participated. Through detailed field experiences and reflections from research actors, this chapter demonstrates how to ethically conduct research with excluded populations and how to intersubjectively produce knowledge resulting from the research project. In this discussion, I argue that both research and writing praxis should involve the participation of the research population. This chapter, therefore, exemplifies how the line between methods (doing YPAR in a care ethics frame) and data/findings are blurred and that the very methods we develop with and for a particular research population is a finding in itself.

In order to ground the information presented in this dissertation in the everyday lives of street girls, the research design and ethics of care underpinning the YPAR project conceptualize data as temporal moments and physical spaces of human experience (rather than raw material for the researcher to analyze and translate). The following paragraphs describe the process of immersion and trust-building in the field necessary to establish the research team (or, in social science language, 'recruit participants'), collaboratively 
construct and carry out the research plan (design instruments and collect data), and collaboratively and systematically analyze the moments and spaces of human experience uncovered through the research (data analysis). This conceptualization of data collection and data analysis as collaborative, participatory and inclusive processes illustrates the “...inseparability of ethics, epistemology and methodology [and demonstrates that]...data analysis processes are key sites for noting the deeply knotted quality of these strands of responsible knowledge construction" (Doucet and Mauthner 2002, 140; Duncombe and Jessop 2002).

I spent two months (November, December 2008) ${ }^{43}$ solidifying local activist (NGO) and academic contacts and made initial contact with the research population (taking accompanied familiarization walkthroughs with NGO leaders and activists, to begin rough visual mapping and to be seen, recognized and accepted as a regular element in the social environment in the drug and prostitution zones in the center of the city).

After becoming a familiar face in the five study sites, establishing connections with street parche (informal gang ${ }^{44}$ ) leaders, and building networks of trust within the community (i.e., identifying safe havens for hiding during a street fight, etc.), I began activist work in order to get to know the girls on a personal basis and facilitate the self-

\footnotetext{
${ }^{43}$ Funded by the FIU Doctoral Evidence Acquisition Fellowship.

44 'Gang' is used here not in the US sense of a structured criminal organization with a name, identifying insignia, norms, entrance and exit rituals and established punishments for norm violations, but a group or band, a loose fraternity of outsiders brought together only by sharing geographical location, social exclusion and drug consumption. A name is usually derived from a spatial identification, e.g. El Parche de la 13 con 20 (The group on 13 Street with $20^{\text {th }}$ Avenue), or from the street name of an acknowledged leader.
} 
identification of peer leaders for the YPAR project (as this cannot be established by the researcher).

In compliance with institutional ethical requirements (IRB), this trust-building process must also incorporate the introduction of informed consent as actions become intertwined with formal research. In YPAR, research and activism are necessarily interdependent and therefore the researcher must establish a protocol for operationalizing this from the beginning of the fieldwork phase. Butz's (2008) identification of the communicative value of the consent process provides a starting point for bridging research ethics protocol and action in the field. Viewing the consent process solely in instrumental terms, he argues, "undermines the potential for researchers to engage participants communicatively in the process of shaping the conditions of their participation to suit the contingencies of social context and self-understanding" (Butz 2008, 251). Therefore, the manner in which the federal Office of Human Research Protection (OHRP) discourse is interpreted matters for action in the field. Instead of limiting the consent process to "...the instrumental purposes of monitoring and control attached to the noun consent," why not develop field practices that facilitate the "...communicative appreciation [and operationalization] of the adjectives voluntary and informed" (ibid)? The objective is to conceptualize and obtain consent using field practices that are “...more meaningful and consensual, more fully context-specific, and more commensurate with a relational approach to research ethics that emphasises sensitivity to contingency" (ibid, 250).

I therefore propose framing human subjects protection in the geographic research process as a collaborative and relational process involving all research actors (i.e., all of 
those touched by the research process). I suggest that this understanding both increases the efficacy of existing institutional protection mechanisms and aligns with PAR principles of mutuality, responsibility and inclusion. Re-conceptualizing protection as collaboration also directly involves the informed consent process, which, while often seen as an obstacle to the flow of human interaction and trust building in the research process, can enrich rather than inhibit communication between research actors (Ritterbusch 2012; Skelton 2008).

The importance of informed consent lies in its communicative value and protective qualities. Communication between research actors regarding project objectives must be initiated well before the implementation of institutional consent requirements; i.e., signing the consent document (or reading the oral consent form, when obtaining written consent has been waived by the IRB). Another essential function of the informed consent process is to convey to participants the ethical principles of choice and protection: recognizing that they are entitled to evaluate the details of the project and decide whether or not to participate, that their contributions are confidential and will not present further discomfort or risk in their lives, and that their participation and time is valuable and (in some cases) will be compensated. The informed consent process parallels the diagnostic interview in psychotherapy, in which the process of evaluating the patient's condition is an integral stage of the intervention. Research process thus becomes intervention and for example questions that generate reflection on drug use may help people to discover and understand the difficulties they face both in their current lives and in the immediate future attempts to change (see, for example, Miller 1991). 
I contend that in order effectively to convey the principles of consent, prospective participants must first recognize value in themselves. In the case of my field research, initiating research with a population of sexually exploited youth whose sense of selfworth is severely debased, required me to begin by working with street girls to recognize the importance of their sexual health (by distributing and motivating the consistent use of condoms and lubricants and discussing safe practices), their potential to help others in the community (by identifying and exerting their rights to health and social services), and the value of their contribution to the research project both in their personal lives and for others in the streets. Participatory action research with street girls, therefore, necessarily calls for a re-framing of consent as a process stretched out over time and space and involving community activism and outreach. This in turn initiates the flow of action research and destabilizes the conventional subject-object structuring of fieldwork in general and human subjects procedures in particular. Thus one of the unexpected findings, potentially applicable to similar future projects with excluded populations, is that the process of making an agreement on consent is in itself the initiation of reciprocity and mutuality, which underpin the entire research relationship.

As girls began calling my phone or showing up at my doorstep to discharge rage, frustration and pain surrounding street trauma, their involvement with the project developed out of a desire to make changes in their lives. I achieved this level of intimacy and trust with the girls by allowing everyday human expressions of constancy and care to 
drive the research process rather than by starting research relations instrumentally vis-àvis institutional requirements such as informed consent. ${ }^{45}$

Obtaining consent does not just happen in one place or in one moment; rather, it happens over time and in multiple spaces through the enactment of care ethics and communicative research relations. In my fieldwork with street girls in Bogotá, I have found that the enactment of caring and communicative field praxis necessarily involves a reconceptualization of 'subject protection.' When La Flaca showed me the social cleansing flyer that had been circulating in the central streets of Bogotá, my head began racing with questions: "Will I find La Flaca on her corner tomorrow or will she be yet another young body thrown in a dumpster? What is my responsibility as a researcher to protect those I am working with from this social cleansing effort?" If the police - whose functions include protecting the vulnerable - are involved in this effort, will I further compromise their safety (and mine) if I report this, given the complicity of Bogotá's police force in disappearances of those denigrated as deviant (both according to my informants and as has also long been established in both local and international research and human rights publications) (HRW 1994; Stannow 1996)?

This ethical dilemma not only underscores the blurred boundaries between protectors and protected, it also highlights that while participant safety is at the forefront of human subjects protection guidelines and debates, researcher safety is often overlooked. Part of developing 'safe' and ethical research practices is establishing mechanisms to safeguard the physical and emotional safety of the researcher in addition

\footnotetext{
45 This ordering of research praxis grounds the Habermasian notion of "...communicative action as ethically prior to instrumental action" (Butz 2008, 250).
} 
to that of the researched (Adams and Moore 2007). Opening up notions of safety to include the researcher re-frames protection discourse from one-way, paternalistic notions to a focus on collaboration between researcher and researched. On countless occasions the girls have protected me in their street spaces far more than I will ever be able to protect them from the violence and abuse of pimps, clients or rival street gangs. Considering this it may be presumptuous to write about the 'protection of human subjects' when the girls have developed a much more effective system of protection, both for themselves and for me, than I can hope to offer them, entering their space as I do only with the ungrounded tools provided by formal human subjects protection protocols based in Federal U.S. guidelines. Furthermore, during the initial months, I could only enter my study sites (the prostitution zone or 'zone of tolerance' and several drug dealing and multi-deviant 'unspeakable spaces') with one of the gatekeeper girls close by my side.

Over the course of my field research, it has become clear that identifying the local specificities of human subjects protection in a society in which the law and human rights are often disregarded is not a process that can be standardized or operationalized from a handbook. Rather, it became a process of learning from the research population how to best protect their lives as well as my own, and collaboratively construct a participatory action research program that not only prevents further risk and discomfort but also makes life more livable. Far better than the OHRP, the girls themselves know their safe spaces and places of refuge, and only they know which state authorities can be trusted and which officials will threaten their lives to collect a brothel pay-off. 


\section{Research Population Subgroups}

I used a snowball recruitment to identify a population of 20 female street youth within the age range of $7-17$ years old and 10 female street youth between the age range of $18-30$ years old. Three additional participants were included in the YPAR project as a result of a complication in the initial mapping instruments. Because of territorial distinctions between different street girl gangs and their own often conflicting group identities, the YPAR team was divided (through team member preferences) into three subgroups.

\section{Table 1: Research Population Subgroups}

\begin{tabular}{|l|l|}
\hline Mariposa Subgroup & $\begin{array}{l}\text { The first } 9 \text { street girls to participate in the } \\
\text { YPAR project, } 4 \text { of which became peer } \\
\text { leaders and } 2 \text { of which participated in } \\
\text { YPAR team activities and the construction } \\
\text { of research instruments. Street girls with } \\
\text { central activity spaces surrounding la } \\
\text { Mariposa. }\end{array}$ \\
\hline Mariposa/'L' Subgroup & $\begin{array}{l}\text { The second group of 14 girls to participate } \\
\text { in YPAR research activities, } 3 \text { of which } \\
\text { became peer leaders and participated in } \\
\text { YPAR team activities and the construction } \\
\text { of research instruments. Street girls with } \\
\text { central activity spaces surrounding (and } \\
\text { shifting between) la Mariposa and la 'L.' }\end{array}$ \\
\hline Transgender Subgroup & $\begin{array}{l}\text { The third group of 10 trans- (self- } \\
\text { identified) girls to participate in YPAR } \\
\text { research activities, 2 of which became peer } \\
\text { leaders and participated in YPAR team } \\
\text { activities and the construction of research } \\
\text { instruments. Street girls with central } \\
\text { activity spaces in the 'zona trans' of Santa } \\
\text { Fé. }\end{array}$ \\
\hline
\end{tabular}




\section{Vulnerable Observation and Intersubjective Knowledge Construction}

Chapters four and five weave together the socio-spatial exclusionary processes that demonstrate, visually and textually, how deviant people and places are represented, linked, and then destroyed in the center of Bogotá and within our five study sites. Two important concepts form the conceptual basis of the organization and textual approach of chapter four. Firstly, Behar's notion of vulnerable observation is employed in this chapter as a means of moving beyond traditional anthropological approaches to participant observation. In section two, I will detail how I operationalized vulnerable observation as an initial, immersive method in my fieldwork and the resultant impact on relationships developed in the field with other research actors. The principles underpinning vulnerable observation were also used to guide the organization of fieldnotes and follow-up analytic text. As Behar notes, "[w]riting vulnerably takes as much skill, nuance, and willingness to follow through on all the ramifications of a complicated idea as does writing invulnerably and distantly. I would say it takes greater skill” (Behar 1996, 13). Vulnerability, in the field, “...doesn't mean that anything personal goes. The exposure of the self who is also a spectator has to take us somewhere we couldn't otherwise get to. It has to be essential to the argument, not a decorative flourish, not exposure for its own sake. It has to move us beyond the eclipse into inertia... in which we find ourselves identifying so intensely with those whom we are observing that all possibility of reporting is arrested, made inconceivable. It has to persuade us of the wisdom of not leaving the writing pad blank...a personal voice, if creatively used, can lead the reader, not into miniature bubbles of navel-gazing, but into the enormous sea of serious social issues" (Behar 1996, 14). Thus, the inclusion of each 
extended fieldnote or interview excerpt in its original form serves a specific purpose in conveying street girls' experiences, feelings, and perceptions of exclusion in their everyday social reality (as a means of preparing the reader for the grounding of this social reality in space upon transition to chapter five).

Secondly, this chapter employs a dialogic conceptualization of reflexivity, in which “...both parties [researcher/participant] reflect back their mutual (mis)understandings and use these as resources for interpreting their different views on the world" (Crang and Cook 2007, 157). In our YPAR project, dialogic reflexivity is operationalized through the participatory writing workshops in which the research team selected important themes or research events for analysis (in fieldnotes, interview, photographs, focus groups, maps, etc.), writing exercises, and reflection. Both concepts demonstrate the manner in which the research and writing activities of the YPAR team and my reflexive, vulnerable writing (both exemplified in this chapter) present a replicable and grounded approach to intersubjective knowledge construction. By employing this approach to vulnerable observation and reflexive construction of an ethnographic text, chapter four works from within the social reality of several principal research actors in order to demonstrate their personal feelings and experiences of exclusion. Street girls' everyday narratives of exclusion presented in chapter four provide the foundation for chapter five, which visually represents how these feelings and the social reality of exclusion intersect with larger, state-sanctioned efforts to spatially cleanse and 'improve' the zones of the center of Bogotá (within our five study sites).

In order to describe how street girls both constructed the methods and used them to analyze their everyday lives and geographies and those of their peers, the story of 
several principal research actors' everyday lived experience of exclusion will be woven throughout their participation in the design of a methodology most effective in reflecting that socio-spatial world. The combination of YPAR team reflections and personal narratives of YPAR team members organizes this chapter through a discussion of data and methods as both yield important findings. The following narratives address the following research questions:

Where do street girls belong and what shapes this sense of belonging?

Where do street girls feel out of place or excluded?

What shapes this sense of exclusion?

\section{Entering the Field}

During my first days working in the streets of Bogotá, all I could see and write about were the external, corporeal aspects of youth sex work: bare skin and exposure, private parts accentuated as public commodities, the distant, glazed eyes hiding behind masks of pink, glittery make-up, empty smiles oozing shoemaker's glue and quickly fading as the brief high subsides and they return to gritty street corner reality. I felt unwillingly (and displeasingly) forced to react predominantly to their highly sexualized presence just as would a potential client or passerby, and to feel the same anxiety over the risks in proximity - infection, violence, manipulation or hostile authorities. Analyzing these initial reactions helped me to understand how others may feel in these contexts and how broader societal perceptions of street girls center on these aspects. I quickly realized that I would have to move through this phase of surface perception to reach the emic understanding necessary for meaningful research.

In providing a 'thick description' (Geertz 1973) of my initial observations of street 
girls, what have I achieved? In attempting to re-present these young bodies and images, has my ethnographic prose accomplished anything more than further dehumanization? Is it ethical to leave my words (and representations) subject to re-appropriation and resubjugation in new exploitative contexts?

One way of addressing these preoccupations surrounding how to re-present Others is, as Behar tells us, through the concept of vulnerable observation and the ability to give an account of oneSelf...with the ultimate objective of leveling the social field between self/other; researcher/researched; insider/outsider (Fieldnote excerpt, November 2008) ${ }^{46}$ The following section will describe how I developed (along with several principal research actors) a vulnerable approach to participant observation during the initial eight months of fieldwork as a means of more effectively researching street girls' geographies and experiences of exclusion.

${ }^{46}$ Excerpt from researcher's personal fieldnotes during the initial immersion phase of the project. 
Vulnerable Observation: Exclusion in the Everyday Life of La Flaca and La Negra ${ }^{47}$

Figure 4.1: Fieldwork Summary Example

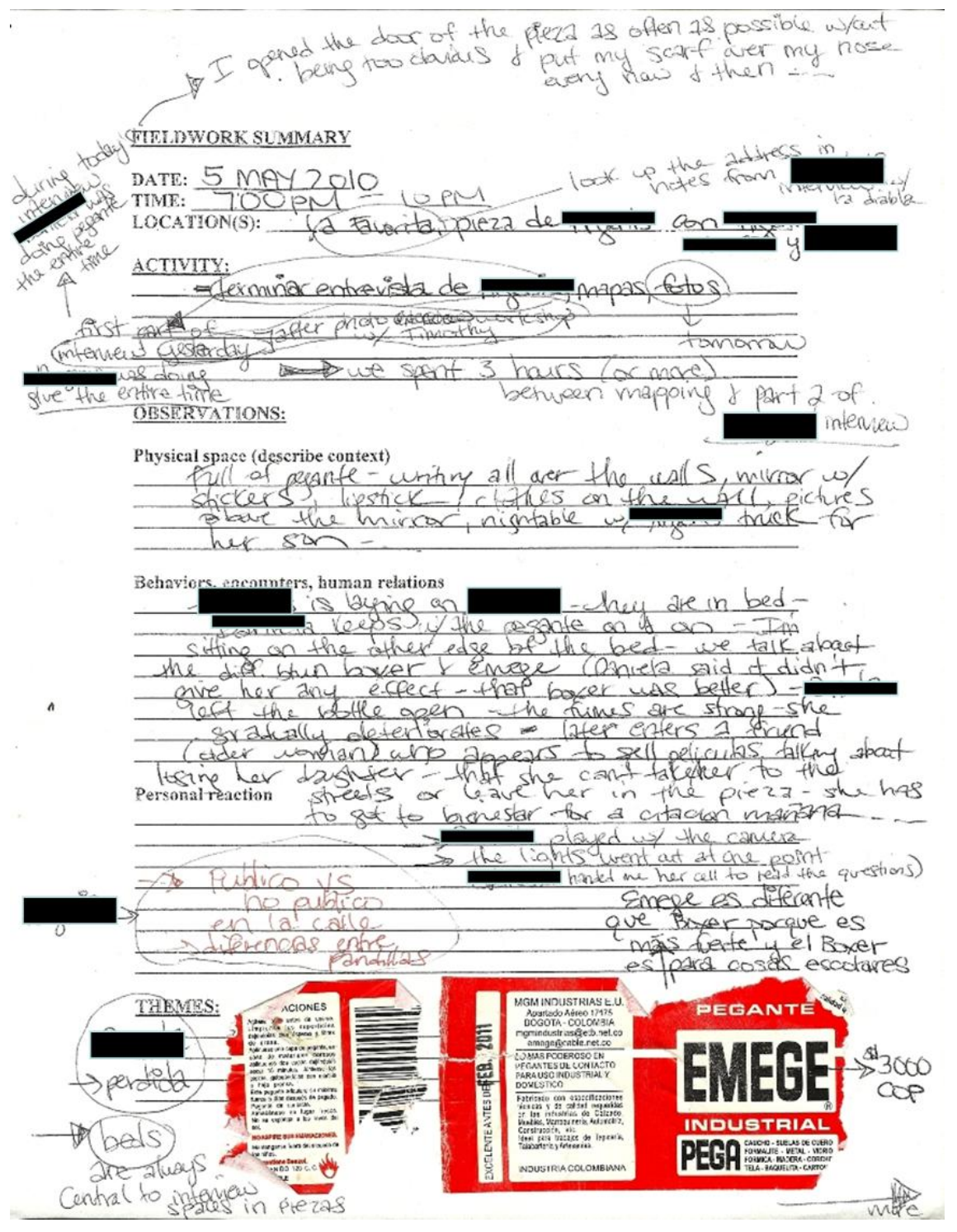

I created the above fieldwork summary form in order to systematically organize and write my fieldnotes everyday on my way home from the field. I almost always stopped at a café or sat on a bench somewhere between the zone and home and wrote my reactions so

${ }^{47}$ La Negra, is a pseudonym chosen to represent one of the main principal research actors and characters in this chapter as this is her actual street name in the zone. Race in Colombia, as elsewhere, is an extremely complex social relation and as such is beyond the scope of this dissertation. 
as not to lose or forget important moments, perceptions, feelings, reactions, or other observations. I would paste flyers passed out by sex promoters or other relevant items collected in the field to the bottom of the sheet to keep the information organized by date, theme, and subgroup context. In the fieldnote example above, I pasted a glue label (after asking on of the girls to take it from her bottle) to remind me of the interview context and specific glue manufacturer.

The point of this section is to express polyvocally how I was able to operationalize the principles underpinning vulnerable observation in the field with street girls. These research praxis will be illustrated from multiple perspectives including my own feelings and interpretations of the field context and my relationships with principal research actors (through my fieldnote excerpts), how members of the YPAR team observed me during my initial immersion period and their suggestions for vulnerable observers working with excluded populations (through street girls' participatory writing workshop excerpts), and street girls' voices and perceptions of their lives and experiences (through street girls' interview excerpts).

By working with one of the principal research actors over the course of the participatory research and writing process, this section takes the point of view of the excluded as its point of departure. For street girls: What is exclusion? What does exclusion feel like? Where does it come from? These are questions that the YPAR team used to frame their personal description of what exclusion feels, looks, smells and sounds like from the perspective of street girls. The process of entering the place-world of "the excluded' also implies sharing spaces and getting a 'whiff' of these experiences of 
exclusion myself as 'the researcher/outsider' in order to move closer to and become part of 'the inside.'

For the Mariposa/' L' subgroup, exclusion, rejection, and their bodily reaction to these experiences revolve around a glue bottle. Many of our initial field encounters had much to do with glue, buying it, sniffing it, hiding it, thinking about it, being depressed or fighting because of it, and so on. As an activist, this presented a complicated ethical dilemma as it was difficult for me to watch the girls doing harm to themselves and I wanted the girls to stop consuming glue. This, I realized, could only come through professional health services and long-term activist work. We eventually made progress with one of the principal research actors through the hip-hop action component of the YPAR project entitled Huele el Cambio (Smell the Change).

As geo-ethnographers, it is important, during our initial months of participant observation, to pay attention not only to the spatial context of research actors but also to other senses (beyond vision), including smell, sound, touch, and the feelings that these observations provoke within us (Thrift 2000; Crang 2003; Crang and Cook 2007). With regard to this observation, Thrift notes “...the narrow range of sensate life..." registered by cultural geographers in their analyses and approaches to representing data (Thrift 2000, 3; see also Crang 2003; Crang 2007). In my fieldnotes, a wide range of sensations are present in quickly jotted sentences about my feelings and reactions to the field context. My initial fieldnotes reflect feelings of disgust and fear for my safety followed by reflections as to how these feelings of repulsion often motivate the abjection and exclusion of street girls in mainstream society as detailed in chapter three. Part of ethically entering and being acknowledged as part of the inner circle of street gangs 
involves overcoming these initial, shocking, exaggerated reactions and not only being 'seen as' but rather 'seeing oneself as' on the inside as well. Once I made this transition and jumped through the hoops of (informal) gang acceptance and trust, my field encounters and relationships started to take shape. It was only at this point, about eight months into fieldwork, that I was able to start planning and gradually take the steps towards a formal research agenda.

For La Negra, one of the principal research actors of the Mariposa/'L' subgroup, immersing oneself within the world(s) of street girls requires stepping into their shoes, one by one. Observation of this type implies and actually requires vulnerability of the researcher/participant observer (Behar 1996).

When asked to express how one should approach vulnerable observation with street girls, La Negra emphasized in a writing workshop that the way to understand and help the girls without judging them is to put yourself in their shoes, giving them a hand, being there and getting into their language and world, "...en el momento preciso donde nosotras queremos desahogarnos con alguien quien no nos fuera a discriminar, rechazar o juzgar por lo que somos (at the precise moment when we want to let go to someone who won't discriminate, reject or judge us for what we are" (La Negra, Participatory Writing Workshop, January 13, 2011). She explained that solely passing out a condom and lubricant does not gain trust with the population. It is those outreach workers who want to hear and understand what we go through on a daily basis and who see us as more than just prostitutes who gain our confidence. Through recognizing that we have the right to belong to society and to have our own dreams, they gain our confidence and through “...un abrazo, una sonrisa, una palabra nos han dado fuerza para poder recuperar la 
confianza en nosotras mismas (a hug, a smile, a word have given us the strength to recover confidence in ourselves)" (La Negra, Participatory Writing Workshop, January $13,2011)$.

\section{Photograph 4.1: Principal Research Actors and Glue}

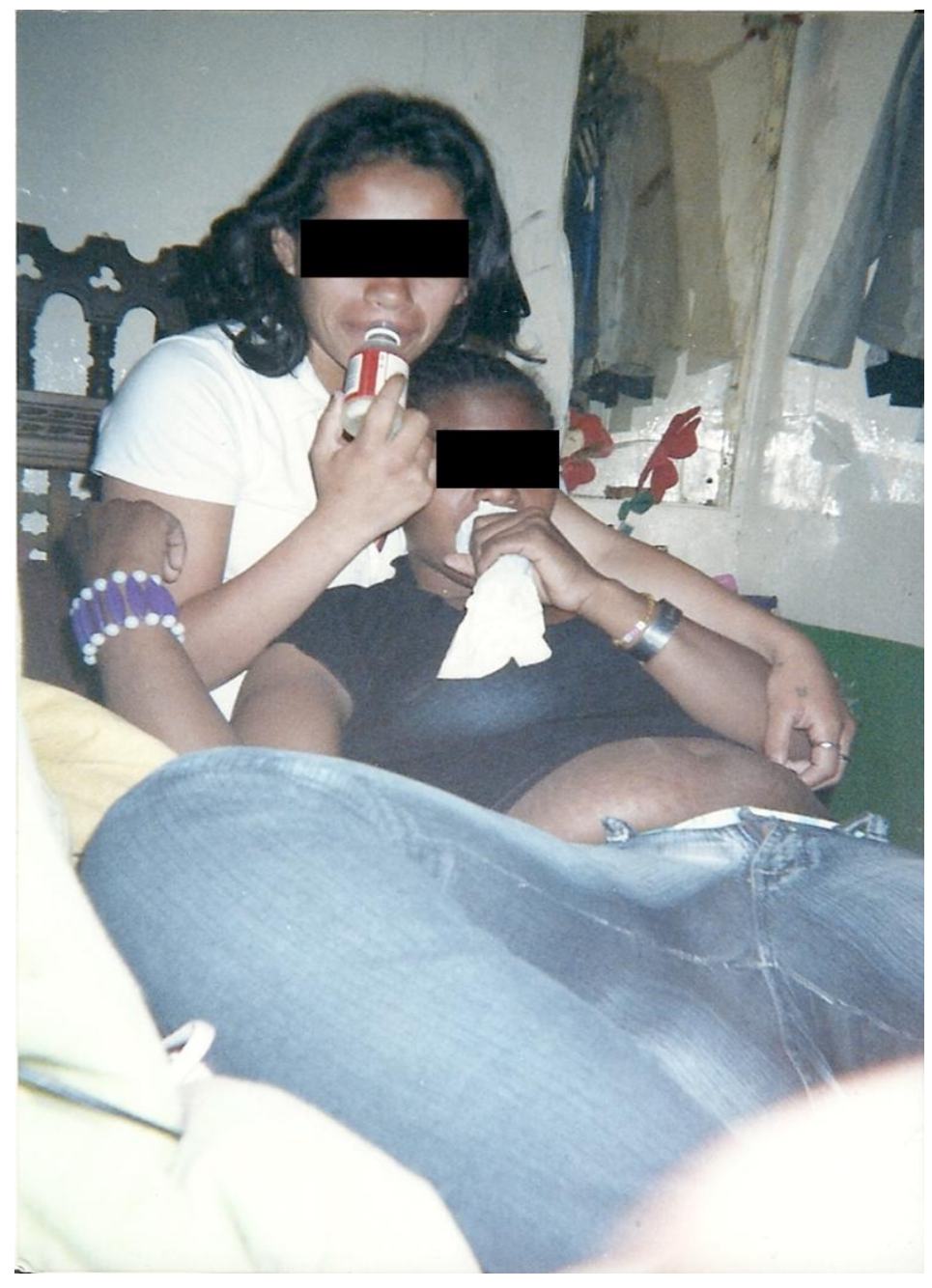

I met La Negra in March of 2009 in a state similar to that photographed above, high on glue and in another world. That day I left my apartment, within walking distance, and ran in and out of stores all the way to the Mariposa to avoid getting too wet before starting four hours of street outreach. I try to avoid doing outreach with an umbrella because none of the girls have one and it makes me stand out (and appear to be spoiled). 
I had about fifty condoms shoved in the multiple pockets of my black outreach jacket and the side pockets of my army fatigue pants were full of individually packaged lubricants to pass out with a condom to each of the girls I made contact or chatted with. Upon arrival at the Mariposa, I was surprised to find several girls out as the rain usually keeps clients away. I slipped into the usual scene, first talking with El Chocoano while he sold cell phone minutes and saying a friendly hello to Tato the shoe-shiner as he packed up his things for the day. Shortly thereafter, someone screamed my name and then squeezed me tightly from behind. It was La Flaca who reeked of la ' $\mathrm{L}^{, 48}$ and appeared even skinnier than last week (seemingly impossible - over the last six months she had already lost a significant amount of body mass as a result of her bazuco addiction). The cycle of her days was running from making money in la Mariposa directly to la ' $L$ ' to smoke it away, day and night for nearly a year. She frantically flailed her hands at me, her way of asking for a condom and lubricant. Behind her, I could see an old, overweight client waiting with his eyes toward the ground. I have noted that clients never make eye contact with me since I became a familiar face in the prostitution zones, although during the initial months I was repeatedly mistaken for a sex worker. No matter how she dresses, a woman standing with a group of other women in la Mariposa or Santa Fé is usually assumed to be 'working' in prostitution. There were definite benefits to my blending in as a Colombian in physical appearance and perceived as a sex worker. I was able to participate in most of the Mariposa and Santa Fé girls' activities without much resistance from other important figures in the streets. I was gradually immersed in street,

${ }^{48} \mathrm{La}$ ' $\mathrm{L}$ ' is study site 2 . This reference refers to the smell of bazuco, marijuana, glue and other substances consumed in la ' $\mathrm{L}$ '. 
prostitution and drug zone activities without actually participating in the sale or consumption of any substance or in sexual acts. As La Negra has told me many times, that demonstrated the difference between myself and other activists known in the zone. I arrived as a person prepared to join with street girls in almost everything they were doing without judgment, criticism or reservation. Other outreach workers, in official institution uniforms and carrying folders and clipboards, uphold the status and distance demanded by their professional roles and institutional restrictions. The girls usually see their giveaways of snacks and candy bars as symbolizing the paternalistic methods of official institutions and not of genuinely caring people. Rather than generating reciprocity and mutuality, these practices maintain status difference, handout dependence and distance.

Before going off with the client, La Flaca pointed towards what appeared to be a lump of clothing in the middle of the Mariposa statue. She asked me, “...cuidame La Negra mientras...tu sabes...(look after the black girl while I...you know what)...” I shyly agreed (as La Flaca was the only girl left there that I knew). Being alone without one of the girls in these locations made me nervous. I walked over to the statue and sat down beside La Negra and nudged her: "Hola ... ¿como...como estas? (Hello, how... how are you?)" She looked up in my direction with unfocused vision and a half smile, lifted the glue bag to her mouth and appeared to be thinking of how to answer. "Estoy bien ...Estoy aqui en lo mio ... ¿Y tu de donde ereeeeeeees?...(I'm fine . . here doing my own thing . .and you .. where are you from?)", she mumbled very slowly. I answered "Estados Unidos (United States)" with a nervous laugh and tried to start the condom and lubricant discussion, the way I initiate contact with a new girl. She kept insisting on my appearance: apparently she had already heard of me, as the friendly gringa who dressed 
oddly in 'matrix military' style of army pants and a long black jacket and who invited $L a$ Flaca to coffee and went on walks with her around the zone. These reflections helped me to understand the importance of appearance in gaining trust with the girls. As appearance, for them, is what determines their success with clients, the girls are very attentive to the appearance of anyone, and especially the newbies, in the zone. That day I made an appointment nearby with La Flaca at 9 that evening, when I finished fieldwork for the day.

\section{Two Important Field Lessons at Knife Point}

A few minutes before 9 my own doorbell rang and, unexpectedly, it was $L a$ Flaca. She remembered where I lived, as once I had pointed to my home as we were walking through the center.

The first field mistake.

She begged me to let her come in, insisting that she had something very important to tell me, it had to be now and it had to be in private. I imagined she had a serious health concern she wanted to talk about as had previously been the case. She sat by the fireplace and pulled out a bottle of Aguardiente (Colombia's trademark strong 'firewater').

She demanded that I share a shot with her to prepare me for what she was going to reveal.

I took a shot, clenching my teeth at the burning taste and attempting to appear 'cool'.

She paced around my kitchen. After a few moments of stuttering she blurted out: "I love you", and took four large gulps of Aguardiente. I froze for a moment and then told her that I also cared for her and her well-being. But she rolled her eyes at me and 
repeated: 'No, Amy, I'm in love with you. I can't live without you. I'm giving myself to you."

I felt trapped and impotent.

At times like this IRB protocols do not have answers for how ethically to negotiate a situation in which participants' feelings are at stake. Although 'feelings' are not standard social science material, they are an essential and invaluable part of human research and involve enormous ethical dilemmas for which there are no formal protocol or legal procedures to follow.

I tried again to explain to her that I thought she was confusing feelings of care for romantic feelings. Her mood shifted swiftly to rage at rejection. She repeated angrily that I could not tell her how she felt and that I must love her back. Despite my suggestion that we talk to the Fénix psychologist, she became increasingly aggressive and manipulative, pulled a knife from her pocket, and threatened to kill herself.

During my fieldwork I had several encounters with knives (e.g., threatened with arrest for being too close when a drug-dealer and petty criminal passed a lock-knife to one of the girls in sight of a police officer and taking several girls to the hospital or Fénix to treat knife wounds). Apart from this experience with La Flaca I rarely felt threatened by a knife.

Another incident occurred more than a year later during a mapping interview conducted by one of the most recently self-appointed peer leaders of the YPAR team ( $\mathrm{La}$ Negra's girlfriend). As part of the research protocol adopted with the YPAR team, we decided to lock the door when conducting interviews in brothels or pay-per-day hotels in the drug and prostitution zones (mainly in the Mariposa/' $\mathrm{L}^{\prime}$ 'subgroup's more violent 
environment). This decision was made for safety and confidentiality purposes as well as to avoid interruptions.

That day we decided to enforce the policy as two of the research actors were fighting. Halfway throughout the exercise La Negra banged on the door: "Let me in!!! What are you doing in there? Come out here and face me!!!”

El Guapo chose to ignore this and keep on going with the interview. The banging started again, this time more insistently. When El Guapo heard glue being huffed on the other side of the door she shouted at La Negra that if she was going get high she would not share her bed that night, and refused to go out to talk with her. We continued the interview although I suggested continuing another day. El Guapo refused: "Let's focus". A third girl stared at the door as loud banging was renewed and suggested after all letting her in. El Guapo nodded her head.

La Negra heard the latch move and instantly barged through, aiming a knife at the group of us sitting on the bed, where we always conducted interviews.

I froze. The moment with La Flaca flashed through my mind. La Negra shouted at El Guapo: "I knew it...where were you last night? I knew you would turn out to be a perra (bitch/whore)... am I not good enough? Hah?" I tried to suggest we go outside and talk. But instead she moved at me, the knife straight out in her hand.

This was the second field mistake.

I should have stayed silent when the field context moved from research activity into a tense couple dispute. In the field all data may be treated as research material and every possible combination of relationships may prove valuable, but somewhere a line may have to drawn when close involvement leads to unnecessary personal danger. These 
considerations of fieldwork danger and research safety are discussed by, among others, Lyng (1998) and Adams and Moore (2007).

This is not atypical as the scars of shallow stabbings are often, like love bites, seen as the mark of sexual possession in these communities. La Negra and El Guapo had already exchanged several stabbings over the course of their relationship and $E l$ Guapo treated the threat as normal. This and the La Flaca incident were the only two moments when I felt unprotected by the shield of the YPAR team from apparently out-ofcontrol rage.

\section{Knives and Perceptions of Urban Space}

The knife can represent aggression or defensive protection as was demonstrated in the participatory mapping exercises when most girls used the sketch of a knife to symbolize dangerous spaces, but paradoxically chose the knife to represent protection from danger, a safe space, i.e., it depends on who holds the knife. Seven street girls, across all three subgroups, used knives in their maps and six girls used knives to illustrate feelings of danger (in the dangerous spaces category of the mapping exercise). One of the girls (example below) used a pink knife to symbolize safe spaces for her in la rockola de rap in la 'L' (to most people one of the most frighteningly dangerous places in Bogotá where even the police do not enter). She also marked this same location as her home space (refer to Map 4.1 below). 


\section{Map 4.1: Perception of Safety}

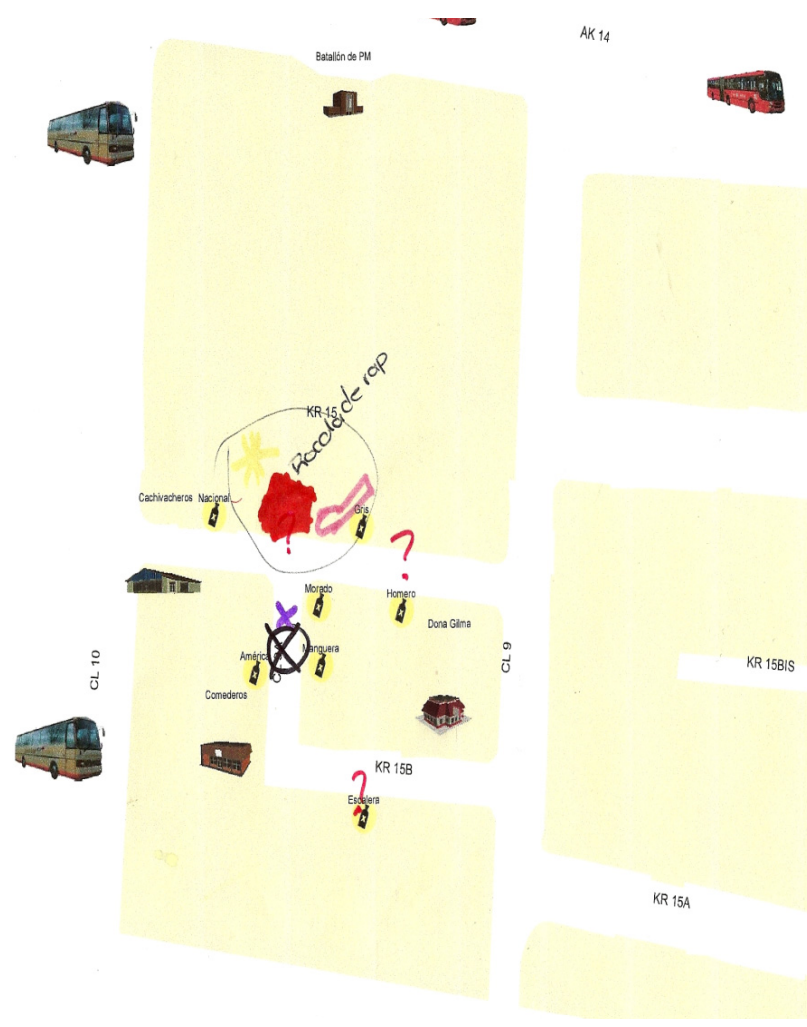

One research actor of the Mariposa subgroup, Biscocho, with a history of stabbings as both victim and author, also drew a huge knife over the three-block area of la 'L,' by contrast, as an exceptionally dangerous zone for her. Thus the knife for these girls can represent either extreme danger or total protection (refer to Map 4.2 below). 


\section{Map 4.2: Perceptions of Danger}

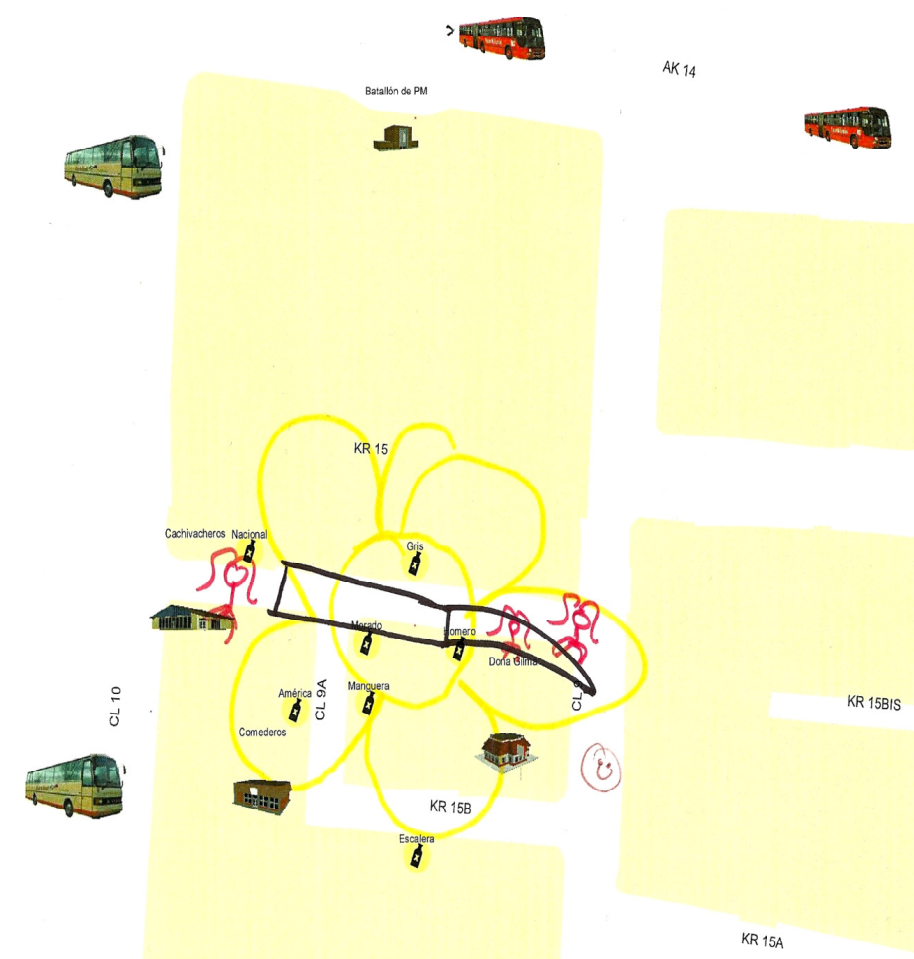

One girl of the Mariposa/'L' subgroup also sketched a pistol beside a knife to symbolize dangerous spaces. Few of these girls carry firearms but all, as expressed in interview data and observed throughout my fieldwork, carry, use and are scarred by knives. (refer to Map 4.3 below). 


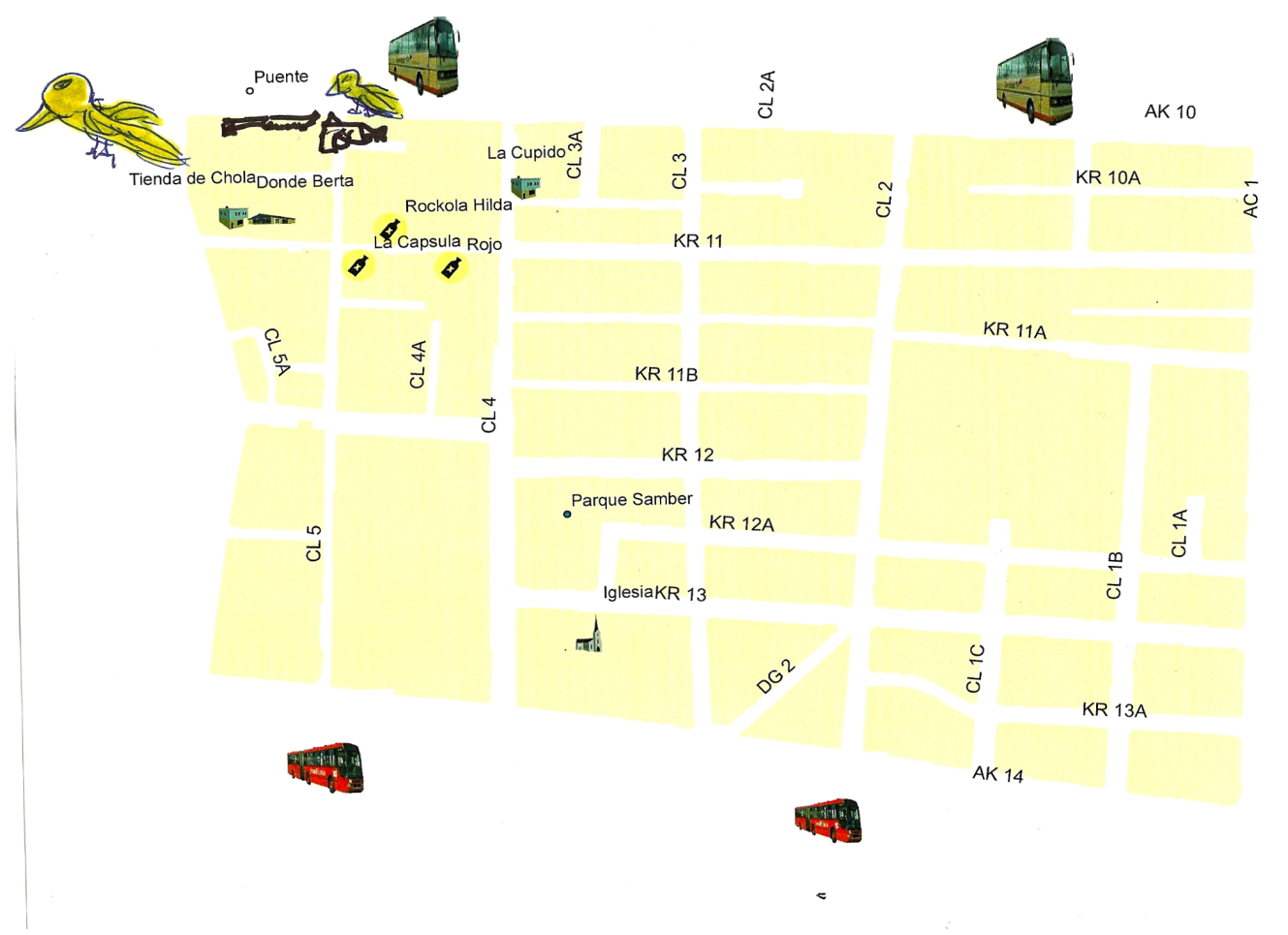

One principal research actor of the Mariposa subgroup, also used a knife to symbolize dangerous spaces; however, in addition to sketching a large knife symbolizing danger in la 'L,' a row of knives, parallel with a purple line of crying faces, mark the path to her mother's home in a barrio in the hills above the center of Bogotá. The seventh mapping category marking the spaces of exclusion in each study site, uses the color purple to represent the pain and sadness of rejection. In this case, her mother's home means both rejection and danger (refer to Map 4.4 below). 


\section{Map 4.4: Perceptions of Exclusion and Danger}

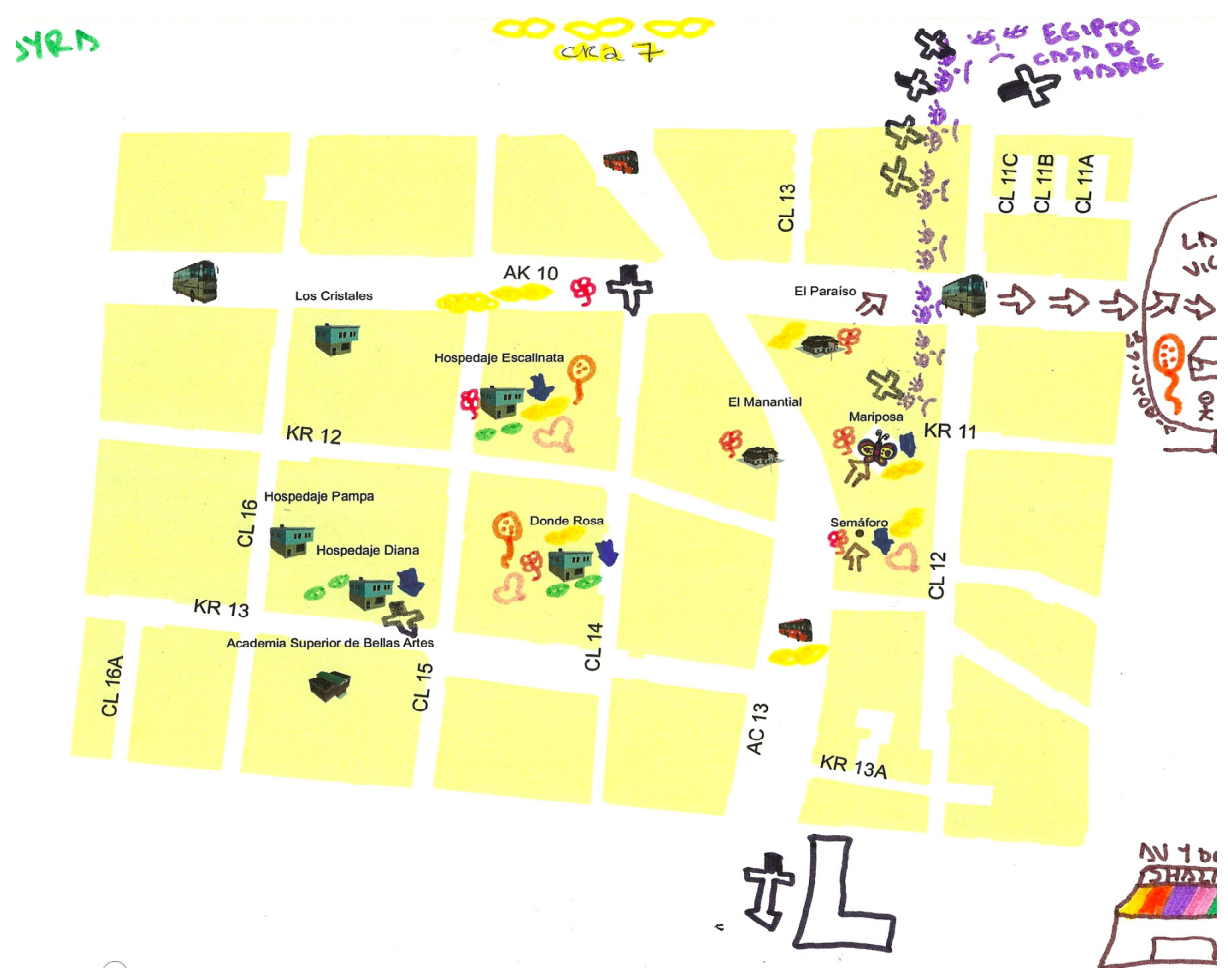

\section{From Stabbing to Caring Relations in the Field}

As a researcher, especially during the initial phase of trust-building, immersion, and vulnerable observation, one has to tread carefully around lived experiences of exclusion and how one's positionality may enact or provoke exclusionary praxis in the field. These experiences helped me to understand, from the 'inside,' what rejection and exclusion feel like for street girls and to understand what emotions a threat or risk of exclusion provokes within the girls.

Through the knife experiences with La Flaca and La Negra, it became clear that a helping hand and expressions of care can easily be mistaken for stronger, romantic emotions. Therefore in every interaction with street girls, I became extremely sensitive 
to how my gestures and interactions with the girls were interpreted and received.

Furthermore, in later YPAR team events that exposed principal research actors to other populations and spaces (i.e., presentations at universities and other institutions), I took extensive, carefully-planned measures to make sure the girls would not feel rejected or judged in these new, potentially hostile environments. For example, our first two YPAR team presentations took place at Universidad de los Andes (University of the Andes in Bogotá), which required additional security clearance procedures for the principal research actors (as the girls did not have formal identification papers). It took me one month to get this clearance with the university; however, the seamless entry of the girls (and avoidance of feelings rejection and additional discomfort in an upper social stratum and high security environment) proved worthwhile.

Towards the end of the second year of research, the YPAR team planned exercises and workshops to review the research experience and reflect on how the diverse experiences helped the team members to grow. These moments became enriching points of reflection and analysis. For example, during a participatory writing workshop more than nine months after the knife incident with La Negra, she expressed that she had not been thinking clearly and “...como estaba peleando con El Guapo iba a dar cuchillo...me sentia con rabia y con ganas de desaparecerla (since I was fighting with $E l$ Guapo, I wanted to stab her...I felt rage and wanted to make her disappear)" (La Negra February 12, 2011). After time had passed, the team members were able to sit together as a group, reflect, laugh, and learn from the situation. La Negra noted that she wanted to make El Guapo disappear because she felt hurt and rejected. La Negra also noted that 
she was scared and that the repetitions of rejection and exclusion are painful for her. In reality, it was those feelings, not El Guapo, that she wished would disappear.

Extreme feelings of rejection and exclusion (as developed in the previous narratives adapted from fieldnote jottings and field diary reflections) took charge and often drove field interactions within the core YPAR team.

In the aftermath of each situation, my relationship with the research actors necessarily shifted and, in the case of La Flaca, was addressed professionally through the support of the Fénix psychologist. Working through relationships of care in the field is a complicated and often painful process for all involved. For La Flaca, we had to work through her feelings and explain that I did not (personally) and could not (professionally and ethically) have any type of romantic involvement with her while stressing that I was not rejecting her.

These situations in the field often do not have rosy endings, as was the case with La Flaca. The day following our formal intervention, La Flaca returned to the streets with even more rage and initiated a knife fight. Her brother called me and I went to the hospital feeling guilty and partly responsible. I went to wish her well and left quickly in order to avoid manipulation as it appeared that she had asked me to visit so that I would see her suffering. La Flaca showed up once again at my house that night close to 3 AM in pain and saying she needed help. A friend, a French volunteer with the International Red Cross, treated her until it was light enough for La Flaca to go home (to the streets). This situation demonstrates the manner in which La Flaca used pain and manipulation as part of her method of dealing with the world. A Fenix health professional noted signs and symptoms of multiple mental health issues in addition to substance dependence. 
Although without sleep, I sat that morning to write my reactions and reflect as to how I needed to change my 'participant observation' protocol in order to continue doing a street ethnography, ethically and without being harmed or indirectly causing harm to other research actors. Both my commitment to the community and my formal research plan required that I continue advancing with the project.

I concluded that it was possible to continue immersing myself in deviant street networks but that I would have to construct every relationship of care in the field with caution and continual reflection. When I planned future research encounters with $L a$ Flaca, I always established limits with a precise destination or objective, which although difficult in these initial and often spontaneous stages of research, is necessary when working with 'excluded' populations. Moving to the 'Inside'

My first meeting with La Flaca after this incident was to go to la 'L.' She called me early one Saturday morning asking to meet and I responded suggesting that she act as my guide through la ' $L$ ' for my first visit there. She laughed and told me to come down to the Mariposa. I was still wary of her but decided to take the risk (with the newly established protocols in mind).

I found La Flaca sitting with her brother, Chulo, waiting on the shoe-shiners' wall. She took me aside and started placing conditions on my entry: "You have to pretend to be my brother's girlfriend, and not say ONE word". On the five-minute walk towards la 'L,' I reflected anxiously that I was walking hand-in-grimy hand with someone linked to right-wing paramilitary units and with a hard reputation as a drugdealer and killer. "What if," I fantasized, " they plan to kidnap and sell me?" My near 
panic made me wonder whether I should run or take the chance to get in (both physically into a difficult to access space and 'in' with the subcultural group). As we passed the church just by the entrance of la ' $L$ ' this well-known criminal piously crossed himself. We walked in; Chulo gripped my hand harder. I was frightened. He pulled me along through the open air drug market, past the rockolas and drifting bazuco and marijuana smoke. I saw two foot cubes of pressed marijuana and large plates full of cocaine on rough wooden tables with customers queuing to purchase. I had to step over people lying motionless in the mud, probably unconscious but possibly dead.

Chulo looked back and winked at me. We finally reached the rap rockola where La Flaca was the drug princess and known to everyone. Tupac's 'Dear Mama' was on the jukebox at high volume. Her brother pulled me into the joint and laughed humiliatingly at my obvious fear.

My heightened anxiety, I quickly realized, had come in part from falling into a shallow 'North American' categorization of all Colombians as kidnappers, cartel members, guerillas or paramilitary and always doing something criminal. I felt embarrassed at my slip into a stereotypical perception of Chulo. I was now very glad that I was 'in' and happily dancing in la 'L' with a leading local crime figure. Nobody treated me as out of place. I had made the crucial transition to the inside of the heart of Bogotá darkness, the city's most notorious and feared no-man's-land and territorio de miedo (territory of fear) (Niño et al. 1998).

My experience in la 'L' with La Flaca and her brother was another defining moment for me during my initial months of immersion. Doing research with street communities about their exclusion requires the researcher to move and think beyond this 
exclusion. It required me to see La Flaca and her brother as more than the sum of the deviant characteristics that are often make it impossible to enter or move within other public spaces. It also required me to find a way to make other research actors feel that they are accepted by and belong to a research team, and for me in turn to feel accepted by and be 'in' with the excluded. Observing and participating in the communities' ways and spaces of belonging and their resistance to exclusion from mainstream society provide first-hand experience of what it feels like not belonging in the city. These experiences reinforced the broader anthropological precept that street life cannot be experienced from the outside.

It can be observed, photographed and followed through hidden cameras or through surveillance technologies, as the state does from the 'bird's eye view.' The popular urban imaginary is shaped by tabloid paper and television reports with clandestine filming and melodramatic commentary filled with rejection, disgust, images of threat and descriptions of the inhabitants as soulless, drugged- out zombies. The content of such reports project negative, frightening images of street communities. The distorted representation of street communities contributes to the way street girls are seen and mistreated in other locations of the city. I therefore stress again that street communities cannot be understood from a distance or by snatching quick and superficial images.

As the months passed, I started going in to la ' $L$ ' several times per week, first with La Flaca and then, when La Flaca disappeared, with La Negra to try to find her. La Negra told me almost a year later that she was scared when taking me to la ' $L$ ' the first time. She said the only reason she took me was because I was the best chance for finding 
La Flaca and that if someone told her I was there she might find a way to contact me. I have described how I felt entering these difficult spaces, it should also be made clear that the research actors also had conflicting and anxious responses to taking me there. In a YPAR participatory writing workshops, La Negra described, on that first day in la 'L', feeling immense fear for me: "porque ya sabemos lo que les pasa a las personas que entran a la 'L' con ganas de chismosear (because we already know what happens to people who go into la 'L' because they want to look around)". She noted that as we left she badly wanted to ask how I had reacted to seeing everyone from children to old people “alli tirados fumando, soplando, inhalando, oliendo, tomando, viendo las reacciones paniciados, engalochados, trasnochados, wueliendo ${ }^{49}$ mal, personas durmiendo en el suelo con ratas a su alrededor (lying there smoking, 'blowing', 'huffing', sniffing, drinking, seeing their paranoid reactions, stoned-out, sleepless, stinking, people sleeping on the ground with the rats)" (La Negra, Participatory Writing Workshop, February 12, 2011).

This inclusion of La Negra's perception of my first time in la ' $L$ ' demonstrates how the initial period of immersion of the researcher/outsider affects the community and how they experience anxieties surrounding the process of YPAR group integration.

We never found La Flaca that day. She is still somewhere 'lost' in la 'L' in the cycle of bazuco, rato, bazuco, rato (drugs, trick, drugs, trick). I have been told that she is still alive but I have not seen her since then.

\footnotetext{
${ }^{49}$ Spelling error in the original text has been preserved. Wueliendo refers to the verb oler (to smell) and in this context indicates a bad smell or stench.
} 
La Negra and I continued working together after this event. With La Flaca lost from the YPAR team, we had to accept that she would not receive or respond to help. I had previously accompanied La Flaca to a hospital and drug rehabilitation meetings, working with her until she could enter a residential unit.

She asked me to come on a visiting day. The clinic supervisor gave us permission to take a walk and get some fresh air. The supervisor trusted me as a fellow outreach worker and foundation volunteer.

La Flaca seemed stable and we talked for almost an hour; but then, abruptly she seemed to switch moods and announced that she was not going back to the clinic. "You can't stop me...I'm going home [to la 'L']...I don't belong here”, she said. I tried everything possible to change her mind but it was not enough. I watched her walk towards the center and back to la 'L'. I felt grief, anger and frustration. I walked back to the clinic and explained the situation to the supervisor and staff.

\section{The Importance of Team in YPAR}

More than a year and a half later, whenever anyone on the YPAR team mentions La Flaca I still feel a sense of failed social responsibility and grapple with the contradictions between the core principles of YPAR and the reality of fieldwork with excluded populations. The principles of mutuality, interconnection, and social responsibility are much more difficult to attain and uphold in research practice.

After La Flaca's disappearance, I began to understand, on a deeper, non-academic level, the importance of a team in YPAR. La Negra has helped to start building our YPAR research project as members of a supportive, collaborative team. After accepting that we did all we could for La Flaca we had to move on with the research process. La 
Negra helped to direct YPAR team involvement in participant observation and immersion activities in different public spaces such as the Parque Tercer Milenio and a bakery in the neighboring Las Cruces district. La Negra also advocated for team involvement within institutional spaces such as a dance performance that she participated in with two peers from la Mariposa at a state-sponsored day center for street girls. This performance motivated the construction of a hip-hop project called Huele el Cambio (Smell the Change). La Negra chose this name, Smell the Change, as a way to fight with spoken words and lyrics against her addiction to glue. In her lyrics she said that instead of sniffing glue she would focus on smelling positive things like the grass in parks or the aroma of fried chicken and she would focus on smelling the changes inside her. La Negra started this movement and I worked to gather the resources and to organize the participation of local hip-hop artists. During street outreach activities, I also motivated the girls on the streets to come to the workshops. In one of our participatory writing workshops, La Negra reflected on our experience with the project and how we achieved participation of the community. She noted that if she had not been there as a model and as a peer leader in the movement, it would have been more difficult to motivate other girls to participate. She also noted that the way I interacted with the girls made a difference. La Negra expressed that regardless of their odor, blistered lips or drugburned fingers, I always embraced each girl, returning a kiss on her cheek (as is a custom in Colombia), firmly grabbing her hands or hugging her tightly if she ran up to me to say hello. La Negra also pointed out, "There are not many people in this city that dare come close to us...let alone show us that they care" (La Negra, Participatory Writing Workshop, February 12, 2011). 
I contend that this is where care ethics plays the most important role in research.

Learning how to belong to and to exude acceptance of the community is a key to uncovering the depths of their exclusion by allowing them to feel comfortable enough to express it.

YPAR Team Construction of the Exploratory Interview Guide

Upon gaining trust and becoming part of all subgroups of the 'excluded' population of street girls and establishing a core YPAR team of research actors within the community, we moved on to the construction of the semi-structured, exploratory interview guides (with specific word-choice alterations for each subgroup). As explicitly stated in my IRB-approved proposal, the semi-structured interview guides that were originally approved necessarily changed and took shape with the input of research actors during the research instrument construction phase of the YPAR process.

The content of the semi-structured interview guides was aimed at understanding each girl's life history as it fits within their general experiences in the city, followed by their experiences of exclusion, rejection, and abuse by state and non-state urban actors. After discussing each girl's life history and experiences of exclusion, the interview concludes with questions regarding each girl's notion and experiences of belonging. Questions 15, 16, and 17, for example, highlight street girls' experiences of exclusion both socially and spatially (i.e., What people make you feel rejected or excluded? Why? In what places do you feel rejected, excluded, or uncomfortable? Why? Has anyone ever forced you to leave a particular place? Please explain.). In order to explore notions of belonging, questions 18,19 , and 20, for example, highlight each girl's feelings of identification and belonging both individually and collectively (i.e., With whom do you 
identify? Why? In what places do you feel most comfortable and welcome? Do you feel that you belong to the city of Bogotá? Please explain.).

The structure of the interview guide was first collaboratively drafted with three principal research actors within the 'Mariposa' subgroup and later (upon transition to work with the Mariposa/' $L$ ' subgroup) edited with three research actors of the Mariposa/'L' subgroup. In a post data-collection, participatory writing workshop, two principal research actors of the Mariposa/'L' subgroup justified the additions by stating that: "Nos dimos cuenta que le hacian falta preguntas concretas sobre la historia del pasado de las chicas en la guia principal (We realized that there were no concrete questions about the [complete] life history of the girls in the main guide)" (La Negra and El Guapo, Participatory Writing Workshop, February 12, 2011).

The additions included more specific questions (and conversation 'catalysts') within the life history component of the interview guide (questions 1 through 5) and focused on exploring gang initiation, substance abuse, and violence dynamics within lowincome neighborhoods in southern Bogotá, family dynamics and composition (i.e., how many members of the family; household structure), primary and secondary school information, and each girl's initial exposure to street life and spaces. The additions suggested and constructed by the principal research actors within the Mariposa/' $\mathrm{L}$ ' subgroup also incorporated nine spatial questions as the final section of the exploratory interview (i.e., Make a list of the 10 most important places in your everyday life. What places constitute your world? Where do you spend the majority of your time? What places do you avoid? Why? Where do you most frequently interact with people? What are your favorite places? Why? Have you observed changes in Bogotá? What changes? 
Do you return to the same places every day? Why (not)? Is there a place you have not returned to? Why?). The girls suggested that these questions would help the team transition from the exploratory, life history focused interview to the participatory mapping exercise. These additions also provided spatial information in thematicallyfocused, narrative form thus complementing the visual data captured in street girls' maps. Upon transition to work with the final subgroup 'Trans-Santa Fé,' two principal research actors leading the research process in Santa Fé edited the exploratory interview guide to accommodate the identities and particularities of the exclusion experienced within the trans-girl community. These additions and edits included changes to question 3 (regarding place of origin as the majority of the trans-population is from outside of Bogotá), insertion of a new question (between 4 and 5 of the original guide) on identification within the LGBT community, two sub-questions regarding her transformation process and the challenges faced in society, a revised question regarding her conception of 'home' including questions about her childhood (refer to question 6 on the trans- interview guide), and the addition of a sub-question to question 20 on her sense of belonging to the city of Bogotá (the sub-question explores her participation in LGBT rights demonstrations and activism in Santa Fé). Yolanda, one of the principal transresearch actors, insisted on the inclusion of this question as many trans-girls participate in the annual LGBT rights parade and view it as an important moment for the community and assertion to the rest of society of their rights and identity. Once per year, the transgirls of Santa Fé see and feel the number of participants in an extensive, largely attended march and become, for a moment, a complete community rather than isolated, conflicting groups. 


\section{Interview Context}

The principal research actors of the YPAR team in each subgroup ${ }^{50}$ also recognized the importance of the interview context in providing a comfortable environment for their peers to express their feelings and discuss difficult topics. Considering the painful and personal experiences discussed during interviews, the principal research actors of each subgroup selected the most comfortable place to conduct the interviews. In all three subgroups the most successful interviews took place in one of the research actor's home spaces. El Parque Tercer Milenio (one of the interview locations chosen by the Mariposa subgroup) did not end up being the most comfortable space if the girl was not part of the principal research actors' territorially defined parche. $^{51}$

For the 'Mariposa' subgroup, 5 out of 9 interviews were conducted in El Parque Tercer Milenio. This interview location was chosen by the research actors leading all research activities with this subgroup. The other 4 interviews were conducted in a more private setting in the apartment of Bischoco and Blue where the parche frequently gathered to hang out with each other. The girls who had not identified themselves as peer leaders (since they were not part of the Mariposa gang) were not invited to these more private, in-depth interviews and therefore did not appear as comfortable during the interviews. The Mariposa lesbian parche of four naturally formed an effective YPAR team through spontaneous activities of trust-building such as a baby shower, dancing at

\footnotetext{
${ }^{50}$ Formal research subgroups (see Table 1, pg. 93) were determined according to informal gang territories.

${ }^{51}$ Parche in this context translates to an informal gang or group of street girls.
} 
lesbian bars, working through break ups, LGBT parade participation, and hospital visits to treat STDs. As an 'insider' within multiple Mariposa informal gangs, I had to tread carefully around the interrelations and rivalries between each parche in order to avoid trouble and conflicts. These moments are what made the research experience (and the formal data collection phases) more effective within this tight-knit group of girls.

For the Mariposa/'L' subgroup, 14 out of 14 interviews were conducted in the principal research actors' private spaces (chosen by YPAR team leaders depending on the desire of each girl/participant). Five were conducted in the pieza of La Negra and El Guapo (their core group), one of was conducted in the girl's personal pieza, 2 were conducted in the personal pieza of a lesbian couple, 2 were conducted in the older Santa Fé pieza of La Negra and El Guapo, and 4 were conducted in the newer Santa Fé pieza of La Negra and El Guapo.

For the 'Transgender/Santa Fé' subgroup, 9 out of 10 interviews were conducted in a trusted space within the community and the private space of one of the principal research actors and peer leaders within the subgroup. Four interviews were conducted in Yolanda's older Santa Fé pieza and 5 in her newer Santa Fé pieza with Tina. One interview was conducted in the private space of the trans-girl upon request for additional privacy and desire to talk about her recently discovered health condition (HIV). 


\section{Photograph 4.2: Exclusion and Consumption}

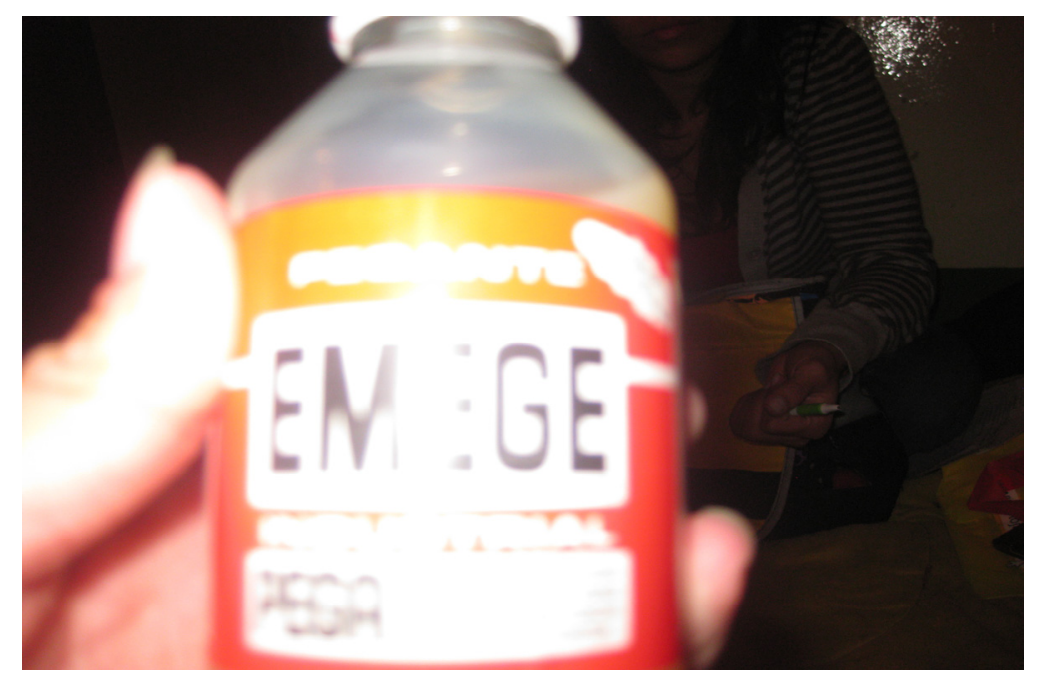

\section{Exclusion and Consumption in Exploratory Interviews}

The interviews were coded for participants' social and spatial perceptions of exclusion and response to the two direct questions in the interview guide (What people make you feel rejected [which was determined by the YPAR team as the most effective concept to explore social feelings of exclusion]? What places to you feel uncomfortable, excluded, or rejected?). Summarizing the results for the entire research population, 9 out of 9 girls in the 'Mariposa' subgroup note experiences of exclusion and rejection related to family, 13 out of 14 girls in the Mariposa/'L' subgroup note experiences of exclusion and rejection related to family, and 7 out of 10 trans-girls note experiences of exclusion and rejection related to family. Interview data show that these early experiences of exclusion led to their exit from their homes and cities of origin. Within the research population overall, 12 girls (representing Mariposa and Mariposa/'L' subgroups) are from low-income barrios in Bogotá including Bosa, Ciudad Bolivar, La Victoria, Las Cruces, San Bernardo, El Clareth. The remaining research actors came to Bogotá from various cities and departments of Colombia including: Pereira, Risaralda (2), Granada, 
Meta (1), Sincelejo, Sucre (2), Neiva, Huila (2), Ibague, Tolima (1), Medellín, Antioquia (2), Cali, Valle (3), Villavicencio, Meta (2), Saravena, Arauca (1), Cartagena, Bolivar (1), Choco (1), Buenaventura, Valle (1). Including the two transgender research actors from Venezuela, all transgender research actors are from outside of Bogotá. They came to the capital seeking a more progressive space for transgender populations only to arrive to a life confined to 3-4 blocks of the city and to many of their peers to social cleansing efforts (see chapter five for more information). Refer to Map 1.1 for an illustration of the cities of origin.

As La Negra notes, her experiences of exclusion are deeply intertwined with her early childhood sexual and physical abuse at home. Describing her everyday experience of this painful feeling of exclusion and resurgent memories of these violations, La Negra discusses in the following recorded interview extract how prostitution forces her to relive the multiple rapes of her childhood again and again every day:

$[U] d$. se va es preparando para eso...ud. entra en un reservado...uno toma una pepa...esta lista...para lo que viene... la minifalda ...la blusita cortica ... ...ud. no lo disfruta...ud. piensa es en la plata...en la plata facil...ya es costumbre...al principio yo tenia que ir loca ...high...ud. estar con una persona ... y yo me acuerdo ...de todo...de todas la violaciones... [bolsa]...no solo fue uno...la ultima violacion fue cuando me quede en embarazo... me acuerdo de todo eso... [bolsa]... a los 19 años empece a chupar pegante... antes de empezar a putear ... a mi no me gusta hablar de mi vida...es dificil...[bolsa] [bolsa] [bolsa]...es que yo quiero hablar de mi vida pero no...[bolsa] [bolsa] [bolsa] [bolsa]...(You get 
yourself ready for this...you go into the brothel...you take a pill [benzodiazepine]...you're ready...for whatever comes...in a mini-skirt...a very short blouse...you don't like it...you only think of the money...the easy money...you're already used to it... when I started I had to be crazy...high...you're with a man... and I remember everything... all the rapes...[sound of glue huffing]...it wasn't just one...the last rape was when I got pregnant...I remember all of that...[sound of glue huffing] ...at nineteen I began to huff glue... before I began prostituting...I don't like talking about my life...it's hard...[huff] [huff] [huff]...I want to talk about my life but I don't...[huff] [huff] [huff] [huff] ...)" (La Negra, Exploratory Interview, May 4, 2010).

These memories of exclusion, rejection, and physical and psychological pain are what initially led La Negra into glue use as an escape route from her body and away from horrific memories. Sounds from her glue bag are constant throughout the interview and most concentrated as she mentions the sexual and physical abuse in her household, subsequent rapes in the street, and missing her son. At times I asked her to put down the bag or to give it a rest but I had no impact on her compulsive use. All 33 participants, in response to the substance abuse question in the exploratory interview, affirm that they have used substances in the past and continue to use one or more substances. La Negra and one other girl in the Transgender subgroup consumed during the exploratory interview.

For La Negra, glue enabled her to escape from the external, physical world of exclusion. As is evident in the above excerpt, La Negra spent the entire exploratory 
interview high on glue. We decided to stop halfway through and finish the following day. In the first interview audio file, it sounds as if we are both in slow motion - the glue affecting both researcher and participant - the fumes gave me a headache and the loose connections in the conversation made me confused.

At each difficult point in the interview, La Negra reached for the bag of glue and escaped from her painful memories through glue. She describes her glue high in the following terms:

El pegante es una substancia la cual sirve para que tu construyas mundos imaginarios...pero poco a poco la ansiedad va deteriorando tu vida...quieres vivir en lo irreal imaginario...donde tu vives lo que quieres vivir...pero cuando te das cuenta el mundo que construiste se convierte en exclusion...sientes en carne propia el rechazo de la gente que te rodea...el mundo que construyes es una realidad de soledad, tristeza, angustia, miedo...te sientes y te ves diferente a los demas...cuando metes pegante por primera vez, piensas que salir es muy facil...pero con el dia a dia...las ganas de consumir aumentan o crecen mas y mas...(Glue is a substance that you use to construct imaginary worlds... but bit by bit anxiety destroys your life...you want to live in the imagined unreality... where you live whatever you want to live...but then you realize the world you constructed turns into exclusion...you feel deep in yourself the rejection of the people around you...the world you built becomes a reality of loneliness, sadness, anguish and fear...you feel and are seen as different from other people...when you do glue for the first time, you think getting out of it 
will be easy...but with the day by day [use]...the urge to use it increases or grows more and more...)" (La Negra, Participatory Writing Workshop, January 13, 2011).

In the above excerpt, La Negra describes the oxymoron of her glue addiction as an escape from feelings of exclusion but really redoubling her isolation. Glue enables her to construct an imaginary world and existence far away from the pain and exclusion of her everyday reality, ultimately only to experience more rejection and exclusion from the outside world and to feel and see herself as different from those surrounding her.

In day two of the exploratory interviews, La Negra described her experience of exclusion, rejection, and denial of her rights to health care services in Bogotá. She recalled being sexually abused by a nun when pregnant in an institution. She belonged to a street gang whose male members stole to buy glue for them all and she enjoyed memories of shared sleeping spaces and group activities. The warm memories of sharing and participation were interspersed with sudden references to fighting, gang members being killed in social cleansing operations, and the nuns beating her. Also painful was relating that she was rejected by her biological mother and felt like an outsider in her step-family.

It is an intriguing paradox that amongst the specific locations where La Negra felt excluded should be the brothels of the center from which she was barred because her lack of state identity papers made her an unacceptable risk to the managers. She was thus pushed into more degrading, publicly visible and less lucrative street prostitution. The girl who has no identity card has no proof she is a citizen and is treated as a non-person within all state entities. La Negra detailed going to an emergency room with a vaginal 
hemorrhage and risk of a miscarriage. She was not treated because she lacked identity papers. La Negra eventually lost her child. Others in the group present during the interview interrupted to add cases of refusal to treat even life threatening knife wounds because of a similar lack of papers. These repeated cases of rejection and denial of rights are constant in the discourse of street communities.

By contrast, La Negra stressed that they were not rejected by bus drivers because "una muestra pierna y los buses nos dejan entrar por la puerta atras por 500 pesos (you show some leg and the bus [drivers] let us in the back door for 500 pesos [less than half price])" (La Negra, Exploratory Interview, May 5, 2010). La Negra described another incident in a cheap cafeteria near the Mariposa where she was even refused use of the bathroom.

In this extract from part two of the exploratory interview, La Negra spoke concisely and with much more energy. About ten minutes into the interview, the electricity was cut off in the building. It was unsettling for me but the girls all seemed delighted and La Negra expressed herself with more ease and comfort. The protection of one's identity by darkness was an unanticipated but added benefit in the interview context. While the lights were off, La Negra was able to reveal painful details about her past such as the sexual abuse by a nun.

El Guapo flicked on her lighter every few minutes and held the flame in front of her face, talking with a low voice and scaring us each time. This changed interview environment created a much lighter mood despite the physical darkness. The anonymity provided by lack of light released us from the constraints of our pre-identified roles in the interview. I was just a voice and no longer the gringa with the bags of research materials 
and El Guapo's voice no longer connected to the smelly feet they had earlier teased her about, and the darkness gave her the power to flick light on and off. La Flaca, as the only one doing glue then, could keep on huffing without receiving looks of annoyance from any of the girls and La Negra could describe the depths of suffering with no one seeing the anguish in her face. When the lights finally came back, thirty minutes later, we had almost finished the interview. El Guapo took the responsibility to look over the interview guide to make sure we had not missed any questions and we all slowly came back to the reality of the hotel room.

The different moods produced in the interviews involving consumption affected all research actors. In the cases of glue and marijuana, the interview environment and interactions were slower and depressive, whereas the interview involving cocaine produced an energized euphoric environment and interactions between all research actors.

La Ocho's (a research actor of the Transgender subgroup) interview transcription revealed similar patterns of consumption and painful family memories. Along with her cut-off shirt with the word "feminine" in pink, she also discussed her trans-identity in terms of her hair. Losing her hair meant losing her identity as a trans-girl. She noted: “...el pelo es lo unico que la hace a uno... una travesti le hace mujer es su pelo...(hair is the only thing that defines you... what makes a trans-woman is her hair)" (La Ocho, Exploratory Interview, July 10, 2010). She describes how she fought with a police officer who tried to throw her out of town in Cucuta (a town on the border of Venezuela) and he cut her hair off in the fight. She was arrested after the incident and defines this moment as what pushed her into glue consumption (as well as other substances). 
Recalling her feelings about losing her hair, she said: "[huele cocaina] [huele cocaina] [huele cocaina] cuando me cortaron el pelo llore como tres dias en la modelo [la carcel] ... a mi me dolio tanto sabes porque.... porque me mi mama hizo todo lo impossible para sacarme y me dolio fue cuando sali de la carcel y la vi esperandome alla...me abrio los brazos y me dijo hijo como lo hiciste ([snorts cocaine] [snorts cocaine] [snorts cocaine] when they cut my hair I cried for three days in jail...it hurt me so badly...you know why...because my Mom did the impossible to get me out and it hurt me when I got out and saw her waiting there...she opened her arms and said son how could you do it)" (La Ocho, Exploratory Interview, July 10, 2010). In terms of family life, La Ocho "soñaba con la familia ...tener papa ... tener mama ...pero no...no fue asi...[huele cocaina] (I dreamed about family... having a father...having a mother...but it was not like that...[snorts cocaine]" (La Ocho, Exploratory Interview, July 10, 2010). As an answer to the rejection/exclusion question, she discusses her experience of childhood abuse at home, her father's rejection of her trans-identity, and a case in which she was denied treatment at a hospital in Yopal, Meta. Social cleansing efforts, especially emphasized by the Transgender subgroup, is also covered in La Ocho's interview. She said that some of her most painful memories of loss and fear provoked by hate crimes, the most violent form of exclusionary urban practices in Bogotá, surround the death of her peers. For $L a$ Ocho, social cleansing in Santa Fé “....ya es como costumbre (it’s now a routine [and a reality the trans-community faces])" (La Ocho, Exploratory Interview, July 10, 2010).

Daya's (of the Transgender subgroup) interview was also very painful for her. It was the longest interview I conducted (close to three hours). She expressed her desire to 
vent and continue talking about the abuse she experienced during childhood and her transition from boyhood to girlhood at a young age as she had not revealed this to anyone before. All three research actors present cried at several points throughout the interview and during a break Daya sat in the corner and smoked marijuana but did not consume throughout the interview (as had been the case with La Negra and La Ocho).

In all three cases, the research actors maintained their regular substance use and wanted to continue consuming throughout the interview. The resulting changing moods frequently brought out different and unexpected memories and associations, previously hidden from self and others. When shifts into disphoria produces the opposite effect, creating reluctance to remember and to talk, the researcher must equally respect this change of emotional tone and right of the interviewee to withdraw from the interview or place limits on the content of the interview questions.

Another important ethical consideration is establishing routes of access to health care professionals in order to overcome barriers to access to state services and to offer mental health support from an NGO psychologist experienced in sexual trauma.

\section{Conclusion}

Chapter four has demonstrated the blurred boundaries between data and methods, protected and protector, insider and outsider for street communities, and researcher and participant in YPAR. Firstly, through the interweaving of discussions of methods (YPAR in a care ethics frame) and data (fieldnote, interview and participatory writing workshop excerpts), I have shown that the description of methods developed with and for a research population is a finding in itself. Secondly, through the in-depth, reflexive discussion of the interdependent processes of immersion and obtaining informed consent, I 
demonstrate the importance of framing human subjects protection as a collaborative and relational process involving all research actors and as stretched out over time and space. I suggest, drawing from two incidents involving knives and feelings, that human subjects protection requires a reframing of 'subject protection' emphasizing the blurred boundaries between 'protected' and 'protector' and the careful development of protocols for both participant and researcher safety. Moving beyond these dichotomous conceptions evident in formal human subjects discourse, notions of protection should therefore consider and involve the consultation of all research actors when developing protection protocols. Thirdly, through the polyvocal narrative surrounding the operationalization of vulnerable observation, I suggest ways to overcome challenges faced in the initial phase of immersion in the field when working with excluded populations and include observations and suggestions from street girls regarding the immersion of an outsider.

It is this very polyvocality of chapter four that presents a means of intersubjectively producing knowledge through YPAR methods and writing. Fourthly, this discussion detailed the crucial moment(s) marking my entrance to the 'inside' of street girls' worlds and how my relationships in the field gradually shifted from 'stabbing' to caring field relations after learning to establish certain limits in my initial fieldwork routine (i.e., selecting particular destinations and objectives for encounters with other research actors). The transition to caring field relations highlights the importance of team in YPAR, the participatory construction of all research instruments and methods (including the importance interview context), and the participatory analysis of data. Street girls helped to select moments for inclusion in this chapter as well as to highlight 
the patterns of consumption in interviews, the frequency of family, abuse, police, and institutions in coded interview data surrounding nodes of rejection and exclusion, and how consumption is often a reaction to feelings of exclusion or rejection (demonstrated both in field encounters and formal research phases). In the following data chapter, street girls' visualize exclusion through their photographs taken during the auto-photography phase and illustrated in both aggregate and individual cognitive and activity maps included throughout the chapter. As in chapter four, excerpts from exploratory, placeperception, and mapping interviews in addition to artistic products from the 'action' component of the YPAR project were selected by principal research actors of each subgroup to accompany the visual illustrations of their spatial exclusion and describe the social meanings in each image. 


\section{Visualizing Exclusion}

\section{Introduction}

In chapter four, street girls' personal perceptions and feelings of exclusion were revealed through fieldnote, interview, and participatory writing workshop excerpts. Chapter four integrated a polyvocal approach to methodological praxis as several principal research actors (myself included) discussed how methodologies and field praxis were developed most effectively to research exclusionary processes and their impact on the lives of street girls.

Building on this context, chapter five presents a visualization of street girls' perceptions of the city and how street girls' activity spaces intersect with broader processes of urban change and renovation in Bogotá. As discussed in the introduction, all five study sites in the center of Bogotá encompass the activity spaces of the three subgroups. These study sites include: Plaza San Victorino, known as la Mariposa and frequented by members of the Mariposa and Mariposa/'L' subgroups; San Bernardo, known as El Samber and frequented by members of the Mariposa and Mariposa/'L' subgroups, the Las Cruces barrio, frequented by all subgroups; la ' $\mathrm{L}$ ' frequented by all subgroups; and Santa Fé, Bogotá's 'zone of tolerance ${ }^{, 52}$ frequented by all subgroups (Refer to Map 1.2).

${ }^{52}$ Literal translation of zona de tolerancia i.e., red light district, an area of legally tolerated and accepted public prostitution according to the city's Codigo de Policia (a municipal decree detailing norms for enforcement of social order and regulation of public spaces, enforceable by police). For the (2010) Codigo de Policia refer to: http://legislacion.vlex.com.co/vid/codigo-policia-bogota-c-42867933, accessed November 4, 2010). 
This chapter employs a visual approach to knowledge construction, moving toward a street girl and street corner cartography that documents streets girls' activity spaces and perceptions of the city before, and in the case of la ' $\mathrm{L}$ ', after urban 'improvement' efforts change the face of the study sites and displace street girls' from their activity spaces. In addition to cartographic images of Bogota, place perception interviews about photographs from research phase III enabled street girls' photographs of the city to "... serve almost as projective stimuli that reveal routinised or unconscious responses that are scarcely thought about by the participants" (Crang and Cook 2007, 112). Examples of photographed spaces of exclusion are included throughout this chapter to illustrate street girls' vision of each study site. All photographs included in this chapter were taken by street girls on disposable cameras during the auto-photography phase (see chapter one). The images photographed by street girls provide a window into the place-world of street girls through their eyes and visually document and humanize spaces that will be or have already been transformed as part of Plan Centro's vision of the center of Bogotá.

Each cartographic and auto-photographed illustration of a space of exclusion is accompanied by a textual narrative of how the space is used and what meanings are inscribed within the space for street girls through exploratory, place perception, mapping interview, and/or participatory writing workshop excerpts. 


\section{Construction of Participatory Mapping Methods}

Eight maps were used during the participatory mapping exercise (research phase IV; see chapter one). These maps include one general map of the six central zones encompassing street girls' activity spaces, five site-specific maps of the official study sites (El Samber, Las Cruces, la 'L', la Mariposa, Santa Fé), one site-specific map of Cinco Huecos (a drug distribution and consumption area south of la 'L'), and one sitespecific map of Chapinero (a zone frequented by members of the Transgender Subgroup both for prostitution work and social entertainment). During a participatory mapping workshop, Satanás, a principal research actor of the initial YPAR team, suggested adding seven site-specific maps with spatial identifiers and features recognizable to street girls. She suggested that research actors spatially orient themselves on the general map (in terms of the proximity of each study site to their daily geographies) delineating their daily movement throughout the city, tracing their recorridos urbanos (urban journeys) and then providing more detailed information in the study site-specific maps containing, in street slang, larger spatial references and labels.

In order to structure the content of each map, I went on walking tours with research actors and we made sketch maps along the way, marking key locations, symbols, streets, stores, clubs, brothels and other spatial identifiers that would make the map familiar for street girls (see sketch map attachments below). Using this information, a first round of maps was drafted, and the YPAR team conducted a mapping workshop with four girls to test the instrument. After conducting walking tours, making sketch maps and holding mapping workshops with several principal research actors in each zone of interest, the eight base maps were constructed in ArcMap 9.3 using data layers 
accessed from the Colombian government's Catastro (Property Registry) Department ${ }^{53}$ through Universidad de los Andes (my Fulbright Fellowship academic institutional affiliation). The following data components were used for the base maps: Bogotá city blocks and streets.

Upon review of the first draft of base maps, Satanás said the maps were too dry and empty for the girls to be able to orient themselves spatially, using instruments organized by city blocks. "We are of the streets," she stressed, "but the world of the streets for us is not organized from this [bird's eye] view." As she carried out a mapping interview, while helping the research actor locate her activities on the El Samber map, Satanás described the utility of spatial reference points and said: “...en la esquina queda la Cupido...la residencia más famosa de allá [del Samber]...Ud. le dice 'Llegue a la decima con tercera'... y Ud. dice... '¿Donde es eso?'...en cambio si Ud. dice 'nos vemos en la esquina de la Cupido'...[inmediatamente se dice] 'Breve, nos vemos allá!'...(on that corner is the Cupid [brothel]...the best known place there [in El Samber]...if you are told, 'Go to $10^{\text {th }}$ Avenue with $3^{\text {rd }}$ Street...you say, 'Where is that?' ...but if one says, 'We'll meet on the Cupid corner'... [you immediately reply] 'Gotcha, we'll meet there!)" Satanás, Mapping Exercise, March 26, 2010).

In this explanation, Satanás demonstrated how working with street names and numbers is ineffective, as street girls navigate through the city using corner stores where they purchase glue, other landmarks like ollas (drug holes), trees, monuments, discotecas, and main public transportation routes (especially bus routes on $10^{\text {th }}$ Avenue and the

${ }^{53}$ For more information, refer to the official webpage: http://www.geoinstitutos.com/colombia/areaestr.asp, accessed August 13, 2010. 
Transmilenio route on Caracas Avenue). The use of visual references to locate places is frequent in low literacy rate communities; for example, in Managua, Nicaragua, postal addresses are frequently listed by reference to such landmarks as: "where the big tree used to be, two blocks down" or "from the ravine, first left" (Rogers 2008). ${ }^{54}$

After this workshop, several elements were added to the maps including Transmilenio and bus symbols, rockolas (juke joints) on la 'L' and El Samber maps, alleyways or corners (using street slang names), a church symbol on la ' $\mathrm{L}$ ' and Las Cruces maps, CAI (police) post symbols in Santa Fé and Las Cruces, and a gasoline station symbol marking the Caracas Avenue, a frequent entry point to the 'zone of tolerance' on $22^{\text {nd }}$ Street (also a Transmilenio stop). This second round of base map construction brought the maps to life and the YPAR team approved the mapping instruments for use in the interviews.

All eight maps were used during the cognitive and activity mapping phase of the interview. Mapping interviews were recorded and administered by YPAR team leaders. First, the research actor sketched her urban journeys on the general map in order to demonstrate the extent of her mobility throughout the city. Second, the research actor selected the study site-specific maps relevant to her activity spaces (eliminating maps of places in the city she does not frequent or use). Third, the research actor selected symbols to represent the nine categories on the spatial questionnaire (see section 2.2) and explained the meaning of each symbol. Fourth, the research actor filled each map with

\footnotetext{
${ }^{54}$ For a rich, journalistic description of the formalization of a visual geo-location system in Nicaragua, see the Time article entitled "Postcard: Managua" (Rogers 2008).
} 
her own symbols illustrating the city as seen through her eyes and according to the spatial variables chosen by the YPAR team of street girls.

Figure 5.1: Base Map Construction - Preliminary Sketch Map

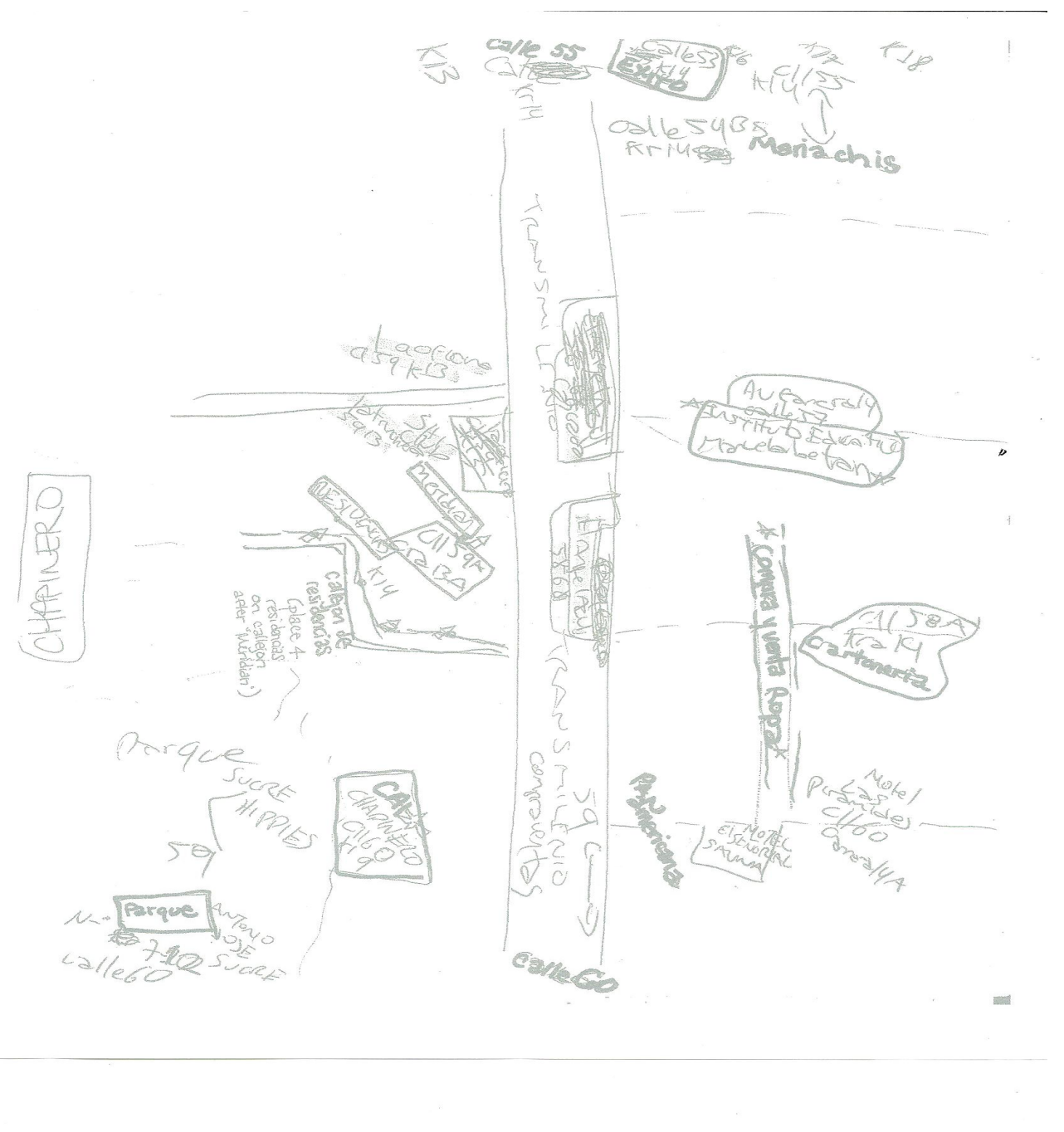




\section{Spatial Variables}

\section{Figure 5.2: Spatial Questionairre Example}

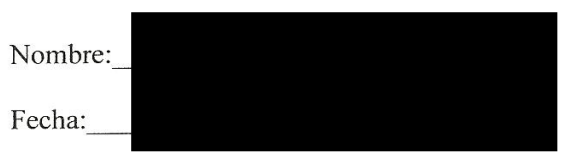

\section{Preguntas:}

1. Ubica los lugares donde trabajas. $(X A z u l)$

2. En que espacios socializas con tus compañeros? (X Rojo)

3. Ubica espacios públicos donde pasas tiempo. (X Amarillo) Mo neda (100)

4. Ubica espacios no públicos donde pasas tiempo. (X Verde) reqa lo

5. Ubica lugares que son centrales en tu vida diaria. $(X \text { Café })^{\text {cu bur }}$

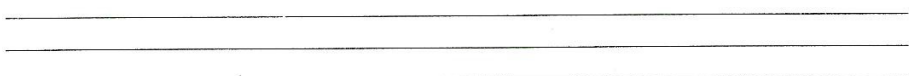

6. Ubica en que lugares te sientes como en casa. (X Naranja)
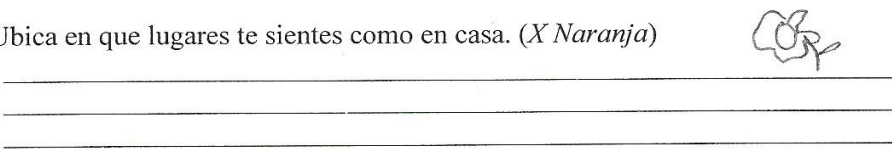

7. Ubica lugares donde no te acepten por $x$ o y razón. (XMorado)

促

8. Ubica lugares seguros para ti. (X Rosado)

@)

9. Ubica lugares inseguros para ti. (X Negro)

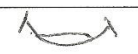


The next step was the collaborative construction of the spatial questionnaire (refer to example above). In the second mapping workshop, the YPAR team worked on the questions and choice of phrasing necessary to collect spatial information about street girls' activity spaces and perceptions of urban space. Tables 2 and 3 display the original spatial variables in my dissertation research proposal and the variables developed by the YPAR team to address these themes. These tables contain the changes made by the YPAR team to accommodate interview conditions, comprehension and choice of phrasing and to give grounded meaning to the abstract terms 'belonging' and 'exclusion' when trying to pinpoint spaces. As shown in Tables 2 and 3, 'areas and places of belonging' (Table 3 - Proposed variables) were re-categorized as 'social spaces' (Table 2 - YPAR variables) and 'safe spaces' (Table 3 - YPAR variables), as the principal research actors expressed that the spaces where they feel they 'belong' are spaces with friends and spaces where they feel safe. Additionally, 'areas and places of exclusion' (Table 3 - Proposed variables) were addressed through the YPAR spatial variable identifying spaces where they are not accepted. 
Table 2: Activity Mapping Variables

\begin{tabular}{|l|l|l|l|l|}
\hline Proposed Variables & YPAR Variables & $\begin{array}{l}\text { Proposed } \\
\text { Notation }\end{array}$ & $\begin{array}{l}\text { YPAR } \\
\text { Notation }\end{array}$ & $\begin{array}{l}\text { Feature } \\
\text { in GIS }\end{array}$ \\
\hline Locations of work & $\begin{array}{l}\text { Places where you } \\
\text { work }\end{array}$ & Blue X & Blue symbol & Point \\
\hline N/A & $\begin{array}{l}\text { Places where you } \\
\text { socialize with } \\
\text { friends }\end{array}$ & N/A & Red symbol & Point \\
\hline Public activities & $\begin{array}{l}\text { Public spaces } \\
\text { where you spend } \\
\text { time }\end{array}$ & Red X & $\begin{array}{l}\text { Yellow } \\
\text { symbol }\end{array}$ & Point \\
\hline Private activities & $\begin{array}{l}\text { Non-public places } \\
\text { where you spend } \\
\text { time }\end{array}$ & Orange X & Green symbol & Point \\
\hline N/A & $\begin{array}{l}\text { Central places in } \\
\text { your daily life }\end{array}$ & N/A & Brown symbol & Point \\
\hline
\end{tabular}

Table 3: Cognitive Mapping Variables

\begin{tabular}{|l|l|l|l|l|}
\hline Proposed Variables & YPAR Variables & $\begin{array}{l}\text { Proposed } \\
\text { Notation }\end{array}$ & $\begin{array}{l}\text { YPAR } \\
\text { Notation }\end{array}$ & $\begin{array}{l}\text { Feature } \\
\text { in GIS }\end{array}$ \\
\hline $\begin{array}{l}\text { Places associated } \\
\text { with 'Home' }\end{array}$ & $\begin{array}{l}\text { Places where you } \\
\text { feel at home }\end{array}$ & Purple X & $\begin{array}{l}\text { Orange } \\
\text { symbol }\end{array}$ & Point \\
\hline Places of belonging & N/A & Green X & N/A & Point \\
\hline Areas of belonging & N/A & $\begin{array}{l}\text { Green } \\
\text { shading }\end{array}$ & N/A & Polygon \\
\hline Places of exclusion & $\begin{array}{l}\text { Places where you } \\
\text { are not accepted }\end{array}$ & Orange X & Purple symbol & Point \\
\hline Exclusionary spaces & N/A & $\begin{array}{l}\text { Orange } \\
\text { shading }\end{array}$ & N/A & Polygon \\
\hline N/A & Safe places for you & N/A & Pink symbol & Point \\
\hline N/A & $\begin{array}{l}\text { Unsafe places for } \\
\text { you }\end{array}$ & N/A & Black symbol & Point \\
\hline
\end{tabular}

As suggested by El Cilencio and Satanás, instead of using a simple ' $\mathrm{X}$ ' or shading to identify spaces, street girls were asked to close their eyes, state the first image that came into their minds for each category and then draw a picture or symbol of it. This methodology yielded rich qualitative data revealing street girls' perceptions of work, notions of public and private, social spaces, central spaces, home spaces, spaces of rejection, and safe and unsafe spaces. In addition to locating these categories in urban 
space, the symbols add another analytic layer of information (as discussed in chapter four's description of knife symbols and street girls' perceptions of protection and exclusion).

\section{Mapping to Visualize Meaning}

The participatory mapping interviews, as in all data collection phases, were organized and administered by the principal research actors of each subgroup. As was the case in research phases one to four, the participatory mapping exercises were conducted in the private spaces of street girls and 28 out of 33 mapping exercises were conducted sitting on research actors' beds using a clipboard to support the maps. Street girls helped their peers locate spaces and orient themselves on the map using terminology and spatial references familiar to the street community. This youth-centric method, drawing from the principles of YPAR, yielded greater detail and depth of spatial data than could otherwise have been collected by an outsider and ensured comprehension of the content of spatial and ethnographic research instruments. The mapping exercise once again indicated that, without formal social science or methods training, peer-leader researchers can produce high quality geo-ethnographic research materials, data, and emic information. Their insider positions clearly made them better researchers and interpreters of otherwise hidden social scenes, leading discussions, developing research themes and exploring explanations for the complexities of their everyday socio-spatial realities.

One research actor in the Transgender Subgroup expressed anxiety over the mapping exercise because of the intensified social cleansing killings in Santa Fé. She asked, "How will this information be used? Can they use it to find and kill me?" Her tone seemed almost joking but she was clearly frightened by the exercise. Before the 
interview, the principal research actor conducting the interview asked me to provide a more in-depth explanation of the objectives of the mapping exercise than was provided in the human subjects and project description at the beginning of each research phase, in order to make her friend more comfortable. I took further time to describe the protections of confidentiality and she eventually appeared to relax in the interview environment and provided detailed information throughout all research phases. This was the only person in the research population to express distrust or discomfort with the mapping exercise, or any other component of the research.

\section{Map 5.1: Visualizing Meaning through Maps}

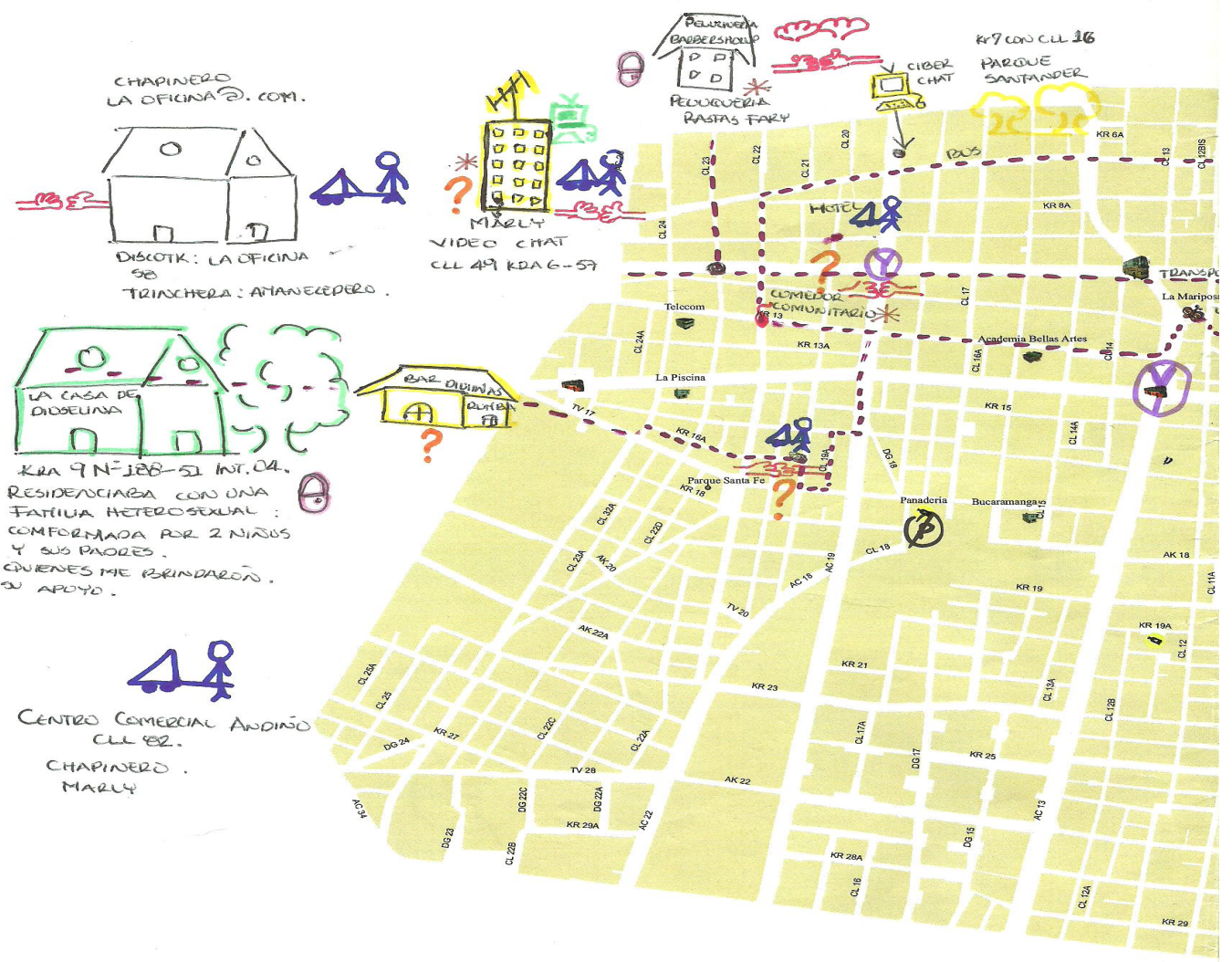


The mapping exercises gave a means of visual expression when interview or photographic approaches and research contexts did not allow the research actor to communicate important information about her life. One research actor in the Transgender Subgroup, Bambi, demonstrated this when the presence of her peers and closest friends prevented her from expressing the reality of secretly living with Human Immunodeficiency Virus (HIV). "I have something important I want to add to my interview," she whispered in my ear as we left the brothel. "Can we do the mapping interview in my house, even though it's far away [in a barrio about 40 minutes by bus from the city center]?" The next day we met in Santa Fé after she finished work and took the bus together. During a trip prolonged by traffic jams in the center, stifling tears and apparently feeling shame, she said: “I just found out I have HIV. I don't want my friends to know." I searched for the right words wondering whether consolation or suggestions for action were more appropriate. I hugged her tightly the rest of the ride as she cried and then we discussed the possibility of obtaining anti-retroviral medication through a UNfunded program in Bogotá and made plans for her to visit Fénix to work on her resumé and seek income options other than prostitution in Santa Fé and Chapinero.

As we climbed towards her shantytown barrio on the edge of the southeastern mountains, the bus climbed and strained with the height. Poverty was steadily more obvious as brick-built houses gave way to tightly packed slums of tin, planks, and plastic; and tarmac turned to narrow gravel and dirt tracks. As we neared the barrio, Bambi pulled out a mirror to wipe off her smeared eye-liner and lipstick, zipped up her sweat suit to cover the pink and white cut-off top, and pulled her hair back into a lower and less feminine ponytail. She had found an apartment far from Santa Fé by disguising her 
income source and sexual orientation. At home Bambi was Carlos who supposedly worked in a restaurant. She never brought guests home.

I slipped quickly through the doorway with no door to avoid being seen by the landlord and I spoke very quietly whilst there. She closed off the bedroom area by hanging a bed sheet across the entrance and we both sat and tried to relax from the emotional pressure on the bus ride.

Bambi pulled out the research materials and started immediately with the map. She spent over two hours working on her symbols and loading the map with her feelings, fears and her everyday lived geographies. This mapping interview was different as there was no constraining presence of other research actors. Although in one sense a safe space, far from Santa Fé and risk of disclosure of her HIV status, paradoxically it was a space in which she could not be true to her own identity and felt threatened by the fear of discovery and homophobic exclusion from the barrio. It is thus important to note that the qualities, factors and agents of exclusion change from one space to another. This helps to explain the often contradictory perceptions of spaces that girls marked on the map as simultaneously safe and dangerous, public and private, both 'home' and exclusion places, and at the same time illustrates how masks may be put on or wiped off for radically different performances of gendered identities as the girls move from space to space.

I sat patiently as she drew and tried not to interrupt, but quietly asked about each drawing and what it meant to her. From Bambi's map and through my interactions with her, it is clear that there are few places in which she feels that she belongs or is accepted. Despite the high prevalence of the infection, HIV-positive trans-girls are still stigmatized within the Santa Fé in-group, adding another dimension to her social and spatial 
exclusion in the city. HIV is the subject of constant discussion, of denial and, frequently, of widespread refusal to be tested (coupled with stigmatization and sometimes overt fear and hostility perceived in hospital staff). Rumors spread quickly and sooner or later invariably reach the ears of clients. Other trans-girls exclude girls suspected of HIV infection from their immediate work spaces and eventually from any space in their wider territory in Santa Fé. Bambi explained her transition to internet prostitution businesses and brothels, as shown on her general map, for these reasons.

Toward the end of our session, she reminded me to keep her secret, thanked me for listening, and said she had no one else she could trust. In this case, the act of making maps gave Bambi an unusual freedom to express and cope with the complicated and painful interconnection between her daily social reality and geographies. Bambi's interview also suggests that the research act of mapping could be a useful tool for initiating interventions in action-research settings utilizing the principles of art therapy as a frame (Furth 1988; Robbins 1994; Malchiodi 1997).

Construction of the Spatial Database, Data Entry and Processing

In order to visualize spatial data representing the activity spaces and spatial perceptions of the research population, ArcMap 9.3 was used to aggregate and display data about individual participants, subgroups of participants, and comparisons between subgroups.

Spatial data were entered upon completion of each mapping interview, per participant (identified by research actor and subgroup number, 1-33). The data entry process included the following steps: entry of the points from each study site map (up to seven maps depending on how many the research actor completed), entry of the points on 
the general map (those that were not included on the study site maps), entry of the 'extra points' in the map margins, and entry of the urban journeys (polylines).

Each physical map from each research actor was digitized and entered in a database in ArcGIS. In the database, each research actor has from two to ten shapefiles of polylines and points (each shapefile corresponds to the specific study site and all points marked on the physical map). Each shapefile has the following attribute table: Color (specifying spatial variables), Symbol (chosen to represent each variable), and Category (nine spatial variables).

The objective of organizing the ArcGIS database by each individual participant was to be able to aggregate information of specific participants and subgroups of participants and make comparisons between spatial variables, symbols, and study sites.

Two additional files were created for each participant in order to include information from 'extra points' and 'urban journeys' (recorridos) in the database.

Extra points were added to include information sketched by research actors in the map margins (i.e., points outside the city, points to the north, south or west of the study sites). Each 'extra point' shapefile has the following attribute table: Color, Symbol, Category, Transport, and Description (place name or details provided by research actor).

Each 'urban journey' shapefile (polyline) traces each research actors' trails throughout the city.

For each oversized symbol, the size was noted in the 'Color' column and the point was located at the center of the symbol. 
Each result map displayed in this chapter was produced in ArcGIS 9.3 by grouping research actors into subgroups and organizing the spatial data according to the 'Category' attribute (nine spatial variables) and study site.

Visualizing Social and Spatial Exclusion - Eliminating People and Places from Bogotá's Center

\section{Map 5.2: Urban Renewal and Geographies of Exclusion}

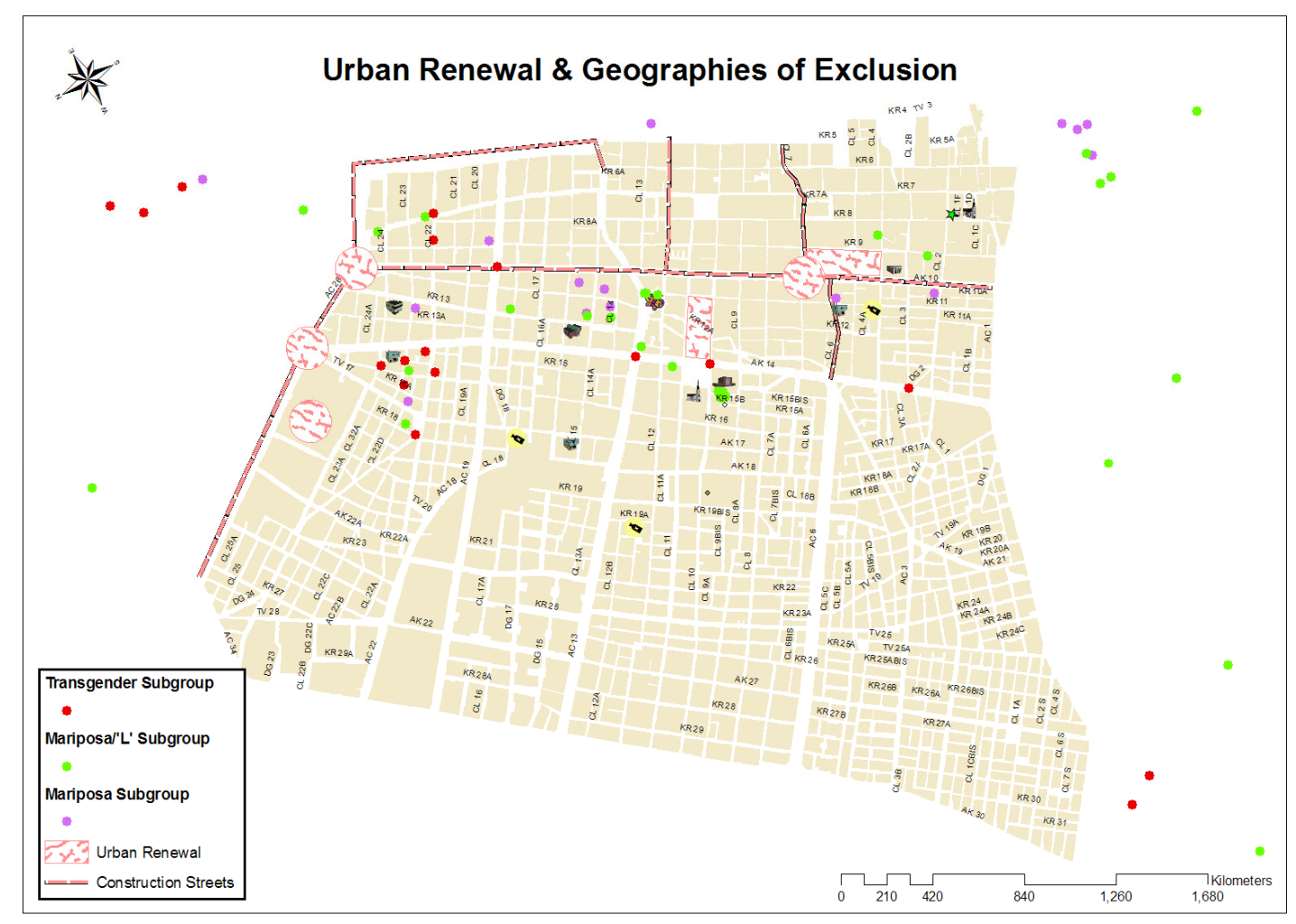

As shown in map 5.2, street girls' spaces of exclusion are often located outside the center of Bogotá and study sites as their perceptions of exclusion and rejection, as discussed in chapter four, are related to family and experiences in homes outside of the center of Bogotá or in other cities. ${ }^{55}$ As the center of Bogotá continues to change, street

\footnotetext{
${ }^{55}$ Points of exclusion in the margins are 'extra points' that street girls included in the margins of the physical map when their locations of exclusion were located in other parts of the city or country.
} 
girls have expressed feeling more uncomfortable and unwelcome (words street girls used to explain the 'exclusion' variable) in public spaces that are being designed for foreign and affluent populations in an effort to make the city center a tourist attraction and competitive commercial hub.

The local government has recently launched Plan Centro, an urban improvement plan targeting the central district of Bogotá encompassing and affecting all five study sites. The introductory video produced by an urban planning department subdivision of the local government states that the principal objective of the project is to change the face of this strategic zone (the center) of Bogotá (http://www.eru.gov.co/index.php?id_c=16\&tpl=articulo, accessed January 24, 2011). It is stated that the four principal goals of Plan Centro are to create "un centro para vivir (a center to live in)," "un centro con equilibrio territorial (a center with balanced territorial use)," “un centro conservado, renovado, y consolidado (a center that is conserved, renovated, and consolidated," and "un centro competitivo (a center that is competitive)" (http://www.eru.gov.co/index.php?id_c=16\&tpl=articulo, accessed January 24, 2011). This all implies that the center does not possess these qualities to date, thus ignoring or rejecting the uses of the center made by the existing populations and effectively annulling them as actors in the scene and certainly eliminating any bottom-up or participatory approach to urban planning and change.

Plan Centro is projected for completion between the years 2004 and 2038, with specific short, medium and long-term goals. The geographic target zone is from $1^{\text {st }}$ Street and $39^{\text {th }}$ to $45^{\text {th }}$ Street (South/North) and from the Circunvalar Avenue to NQS Avenue (East/West). The target zone encompasses all five study sites. On the basis of the 
implementation of short-term construction projects as described in this chapter, Plan Centro starts with the improvement of areas in and surrounding our five study sites. Plan Centro is a strategic urban improvement effort funded and directed by the Hábitat program of the Alcaldía Mayor (Bogotá city administration).

\section{Map 5.3: Urban Renewal and Activity Spaces}

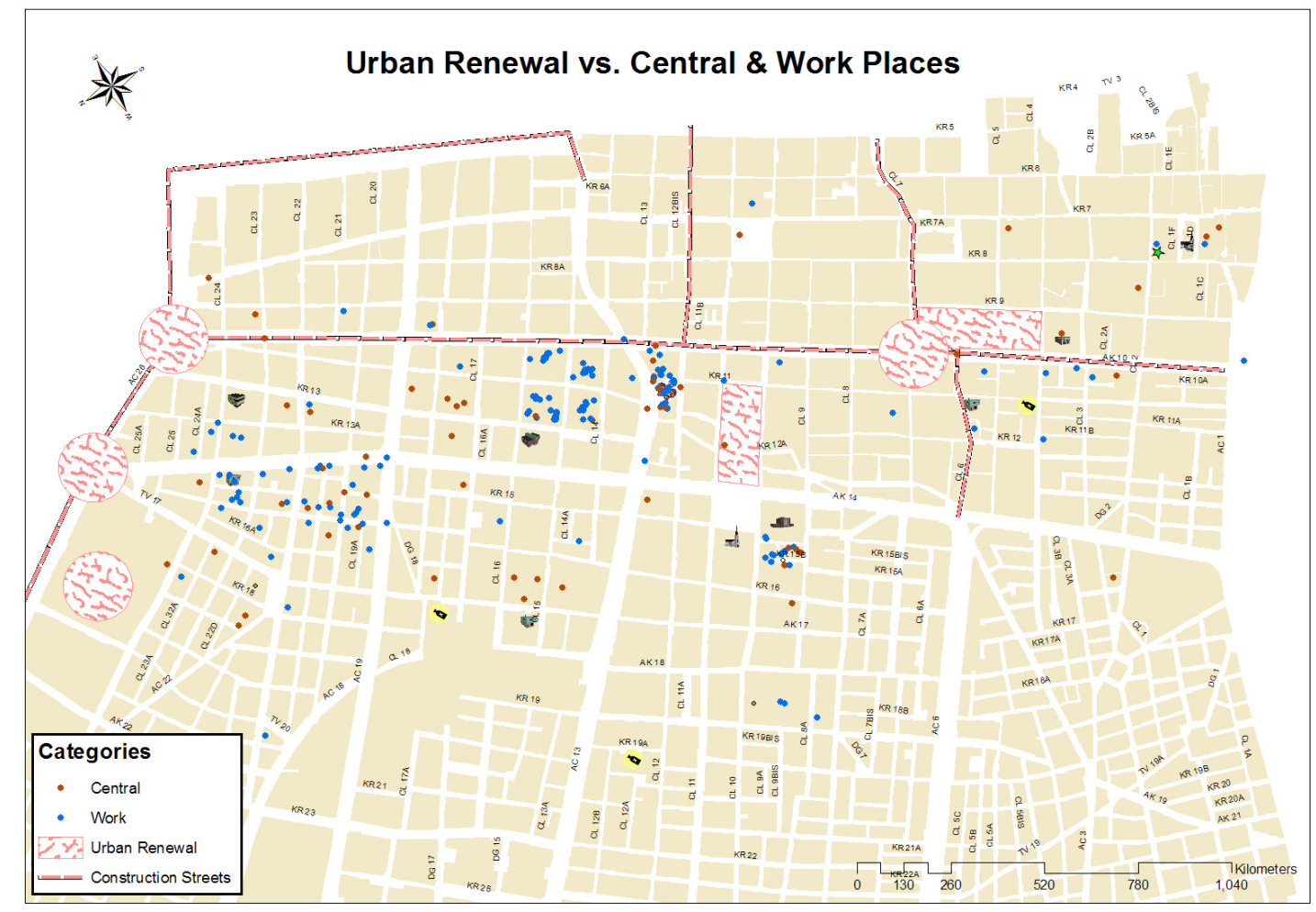

Street girls' everyday lives and geographies revolve around the center of Bogotá. This is illustrated by La Costeña who, when asked what places constitute her world during the exploratory interview, stated, “¿Que lugares?...El centro...yo nunca salgo del centro ...vivo cerquita al centro, trabajo en el centro, mis amistades son del centro ...el parque la Mariposa, la olla que queda en el centro que es la ' $L$ '... a veces voy al Samber...Las Cruces...(What places [are my world] ?...the center...I never leave the center...I live close to the center, I work in the center, my friends are from the 
center...the Mariposa park, the dope zone of the center which is la ' $\mathrm{L}$ '...sometimes I go to El Samber...Las Cruces)" (La Costeña, Exploratory Interview, February 11, 2010).

These sections have detailed the manner in which urban improvement efforts located within or adjacent to our five study sites (refer to Map 5.2 and 5.3) have sanded off the irregularities and rough edges to polish the image of the spaces of deviance, displacing, removing and sometimes eliminating people from those spaces. The final section of this chapter discusses how the transgender population experiences spatial exclusion in a different form, illustrating the extreme limitation of their mobilities to three blocks in the city through photographs, maps, and interview excerpts and demonstrating the paradox of their geographies of exclusion.

\section{La 'L': From El Cartucho to El Parque Tercer Milenio}

\section{Map 5.4: La 'L' - From El Cartucho to El Parque Tercer Milenio}

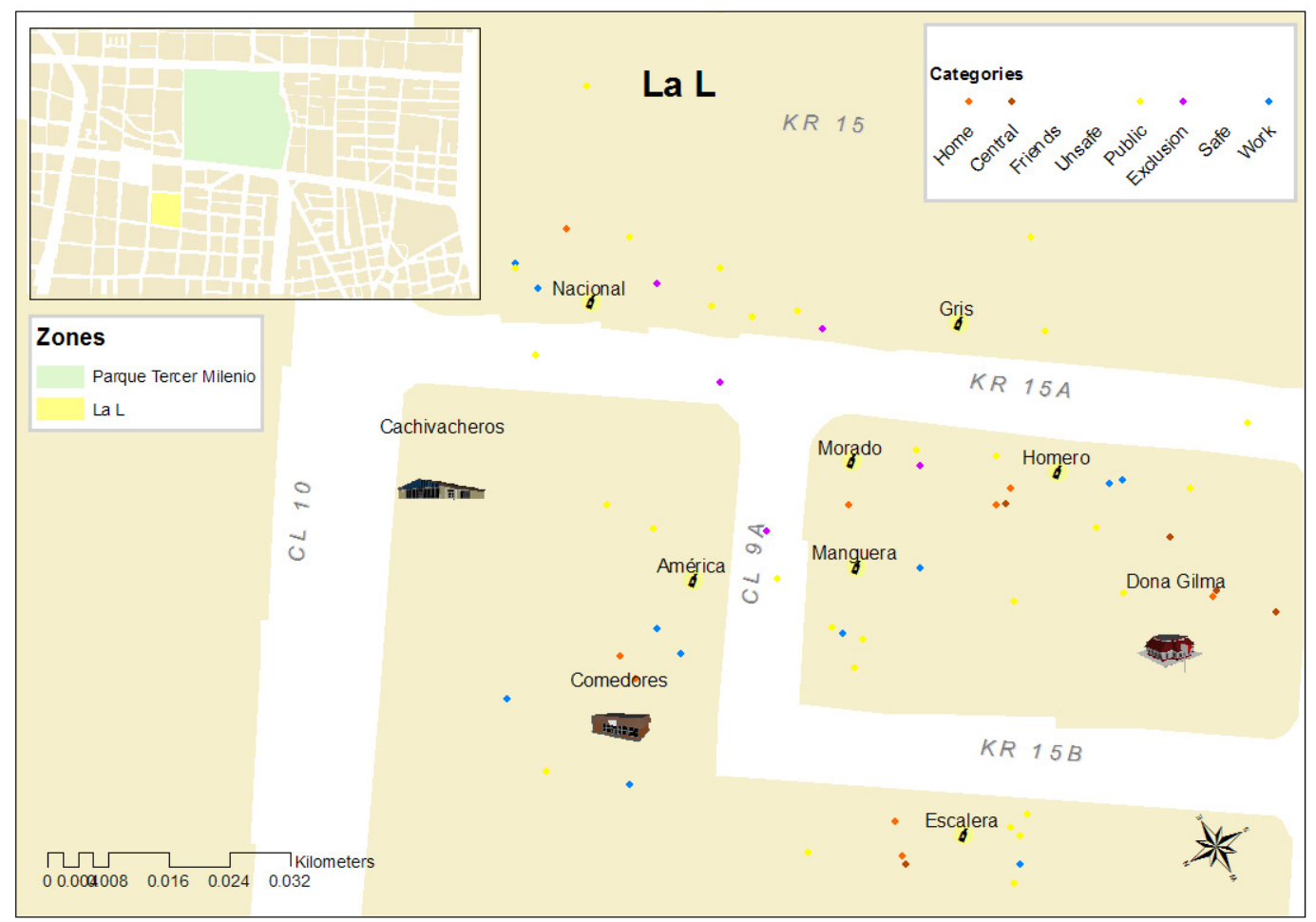


Five out of nine spatial variables (work, public, central, home, exclusion) were selected to visualize street girls' activity spaces in la ' $L$ ' in Map 5.4. Mapping interviews conducted with several of the 17 research actors who placed themselves in the map of la 'L' (with at least one of the five spatial variables) were used to create the following narrative, with stories about the symbols chosen by these girls to represent la 'L.' Additionally, woven in to the stories is material from roving focus groups, exploratory interviews, mapping interviews, and auto-photographed images. Using these place stories, the objective is to humanize and bring map 5.4 to life through the voices and vision of street girls.

Along with street girls' activity points in la 'L,' the main streets of which form the letter 'L' (hence the name), map 5.4 illustrates the location of El Parque Tercer Milenio between la Mariposa and El Samber and how this new public space has smoothed over and is obliterating the histories and place memories of the former El Cartucho.

Beginning with interview excerpts, this section illustrates visually and textually the transition and modification of space from El Cartucho to la 'L.'

As described by Satanás, El Cartucho was buried by El Parque Tercer Milenio, the family- and community-centered park finished in 2005 as one of the first projects of Plan Centro. La ' $\mathrm{L}$ ' is what remains of El Cartucho and constitutes the largest and most dangerous drug distribution and consumption zone in Bogotá. In her exploratory interview, Satanás describes her experiences in El Cartucho and provides her perspective as to how the space was eradicated through an urban renewal project. She described the family problems that took her to this area, mugging and selling drugs and beginning to use them: 
[C]omenzaron a derrumbar las casas y nosotros comenzamos a hacer unos 'cambuches'... para dormir... a mucha gente ...la desaparecieron de manera forzada y violenta ... comenzaron las desapariciones muy a menudo...ese espacio [El Cartucho] se convirtió como en una zona de guerra, heridos, muertos, enfermos...además de que hoy en día eso es el Parque Tercer Milenio...(They began to knock down houses and we began making shacks to sleep in...many people...were forceably, violently disappeared...the disappearances became frequent...this space [the Cartucho] turned into a war zone... with wounded, dead, sick...moreover today this is all the [El Parque] Tercer Milenio) (Satanás, Exploratory Interview, March 31, 2010).

She referred to a home-made mortar bomb aimed at the then-President Uribe that landed short and killed 27 people in El Cartucho. Despite evidence to the contrary, she repeated a popular myth that the explosion was really caused by a police attack against the 'Cartucheros.' Although there is overwhelming evidence of continual police hostility and killings, the distorted interpretation of this event typifies the exacerbation of conflict with authorities by the permanent perception and expectation of lethal violence. Satanás explained the conflict with the police:

“...porque nos querian sacar a la fuerza....nos disparaban y todo eso fue una guerra ... (because they wanted to get us out by force...they fired on us and all this was a war)" (Satanás, Exploratory Interview, March 31, 2010). 
She continued to describe forcible displacement with compulsory purchase orders and police evictions in all the surrounding areas subjected to urban renovation, causing repeated moves from barrio to barrio and street to street, in San Bernardo (El Samber), Las Cruces, Santa Fé and most of the center ending up in la 'L,' with other refugees from El Cartucho. The forced displacement generated further conflict and killings as she said la 'L' residents and leaders resisted invasion by those from El Cartucho. She said that later, from both territories, the leaders joined forces to organize security, drug sales and money movement and paying off the authorities.

Throughout her interviews, killings and violence are constant images:

...[A]bogados, actores, modelos de televisión, extranjeros, doctores, much a gente que llegaba con mucho dinero y a unos los mataban otros se morían de consumir tanto...(... lawyers, actors, television models, foreigners, doctors, a lot of people that arrived with a lot of money and some were killed and died from using too much)" (Satanás, Exploratory Interview, March 31, 2010).

She explained how she saw the ways murdered people were 'disappeared ${ }^{156}$ : ...[H]abía un sitio que quedaba en la calle 9 con 14 le llamaban el 'CONTAINER', alli echaban los muertos y se daban cuenta cuando venían a sacar la basura, pero muchos de esos cuerpos los picaban y los echaban en bolsas. De esa gente a muchos uno se los encontraba con impactos de bala, acuchillados, golpeados...les daban como 2000 pesos

\footnotetext{
56 'Disappeared' is used in this sentence as a verb. This usage is common in Latin America and especially Colombia with the incidence of kidnappings and disappearances but does not exist in English.
} 
para que ellos los sacaran [los cuerpos] en unas bolsas y habia un cucho que le decían el 'BALLENO'o 'VALLUNO'...ese señor mató a mucha gente y cuando el mandaba a que se llevaran algún cuerpo y el pelado no lo hacía el lo mataba y mandaba por otro pa' que botara los dos cuerpos...(...there was a place on 9th Street with 14 called 'the CONTAINER', and the dead bodies were thrown in there and were noticed when the garbage was taken out, but many of these corpses were chopped up and put in garbage bags. Of these many were found with bullet wounds, stabbed, beaten...[young body collectors] were given about 2000 pesos [1.2 USD] to take out [the bodies] in bags and there was one old man known as 'WHALE' or 'Valle de Cauca man' ...this man killed a lot of people and when he gave the order to get rid of a body and the boy did not do it, he killed him too and sent for another to get rid of both corpses...) (Satanás, Exploratory Interview, March 31, 2010).

Satanás' account of her several years of experience in El Cartucho and her forced movement to other surrounding areas, including El Samber, Las Cruces and la 'L,' illustrates the untold reality of what lies beneath El Parque Tercer Milenio. As Satanás points out, the inauguration of El Parque Tercer Milenio in 2005 was just the beginning of a large-scale urban renewal plan for Bogotá's entire central district. Satanás stated that she feels that: “...hemos sido indignadas y víctimas del desplazamiento, aunque simplemente desde los barrios pero igual nos han desplazado (...we have had our dignity taken away and been made victims of displacement, even if only from the barrios, just the same they have displaced us)" (Satanás, Exploratory Interview, March 31, 2010). El 
Samber and Las Cruces, both located within blocks of El Parque Tercer Milenio, are currently targeted in urban renewal projects initiated in 2009 and which continue. Images of urban renewal projects are illustrated in each study site map included in this chapter.

Visualizing the proximity of street girls' activity spaces in la 'L' to El Parque Tercer Mileno and its history, Map 5.4 illustrates the spatial attributes of the 17 research actors that marked la 'L' map corresponding to at least one of the following five categories: work, public, central, home, exclusion. The stories of several research actors featured in la 'L' map are detailed in the following narrative tracing the steps of a YPAR roving focus group conducted in and around El Parque Tercer Milenio and la 'L.'

Three exploratory interviews were conducted that day in El Parque Tercer Milenio by principal research actors of the Mariposa subgroup. A focus group of five girls was then organized to follow the girls' urban journeys from El Parque Tercer Milenio (the interview location), across Caracas Avenue and around the perimeter of la 'L,' and back towards la Mariposa, weaving through ten blocks of wholesale stores soon to be replaced with the new International Commercial Center. During this roving focus group, one of the girls took pictures of the places we discussed as a group. As her interview was conducted in El Parque Tercer Milenio, La Costeña took pictures of the elements of the park that interested her.

She took a picture of the swings, reflecting in a sad tone that she would like to spend more time playing and less time 'working' in the Mariposa. 


\section{Photograph 5.1: El Parque Tercer Milenio - Swings}

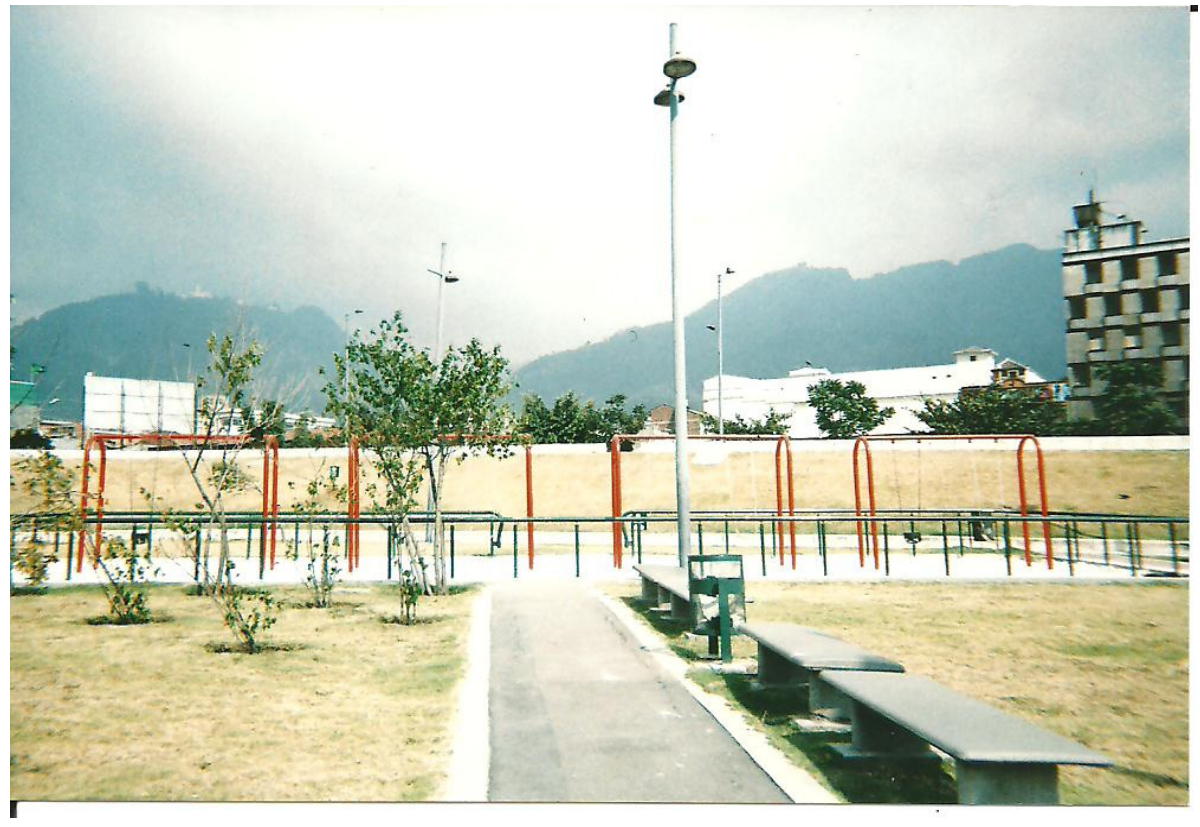

La Costeña, who had just completed her exploratory interview, pointed at the patches of grass by the covered picnic areas and said that she sometimes sleeps in the grass after she has turned at least two tricks in the morning and takes a break before her afternoon 'shift'.

\section{$\underline{\text { Photograph 5.2: El Parque Tercer Milenio }}$}

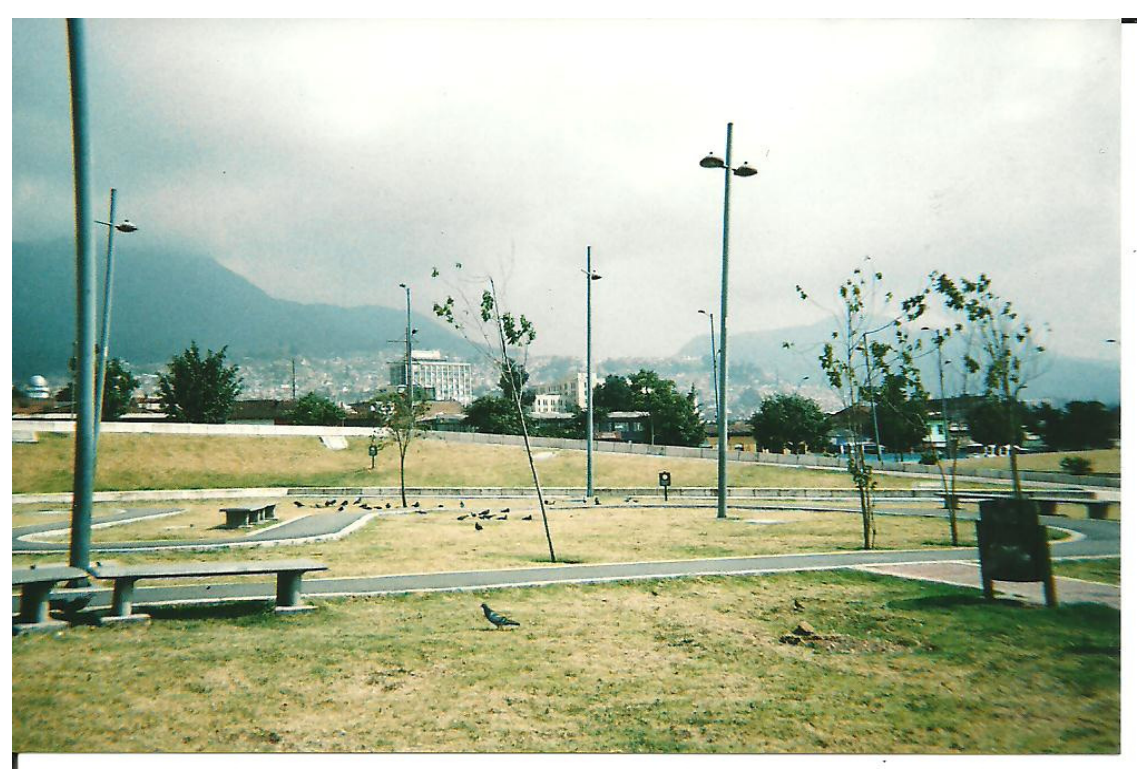


As we followed the path towards the northeastern exit of the park towards la 'L,'

Photograph 5.3: El Parque Tercer Milenio - Towards la 'L'

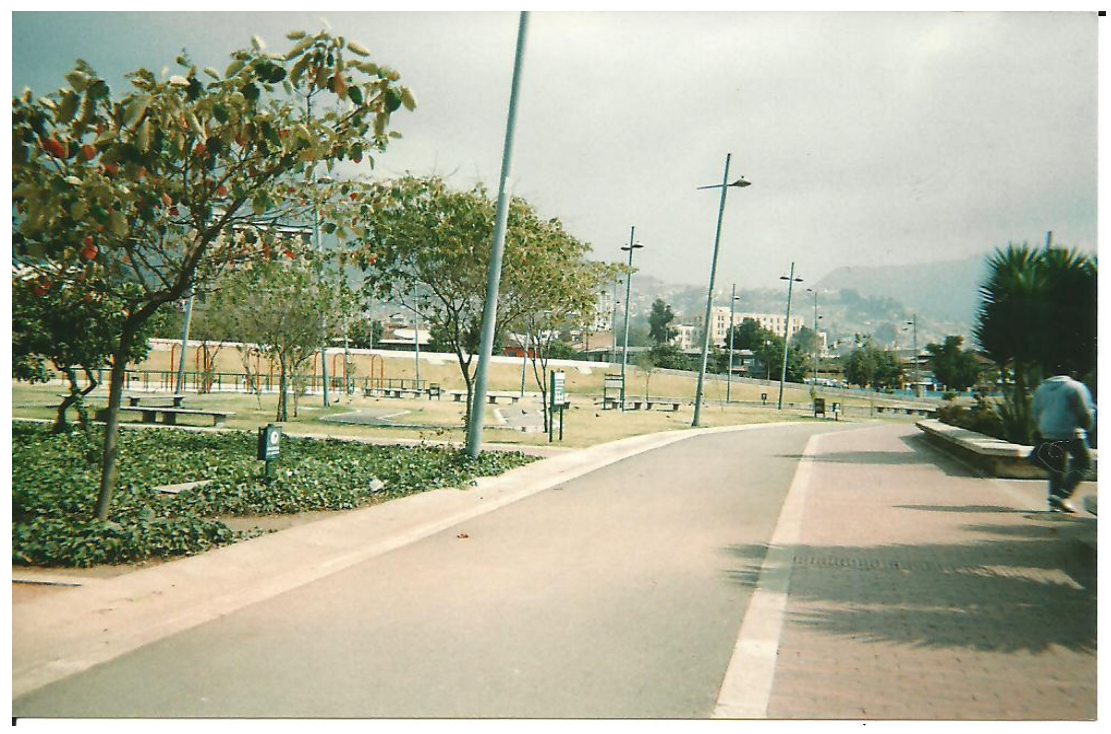

Biscocho observed the emptiness of the park and Blue took a photograph of two

policemen passing by who looked at our group with suspicion, saying in response:

"hijueputas...tombos tan desocupados...que nos dejen en paz (sons of bitches...cops with nothing else to do...just leave us alone)" (Blue, Roving Focus Group, February 11, 2010).

\section{Photograph 5.4: Police}

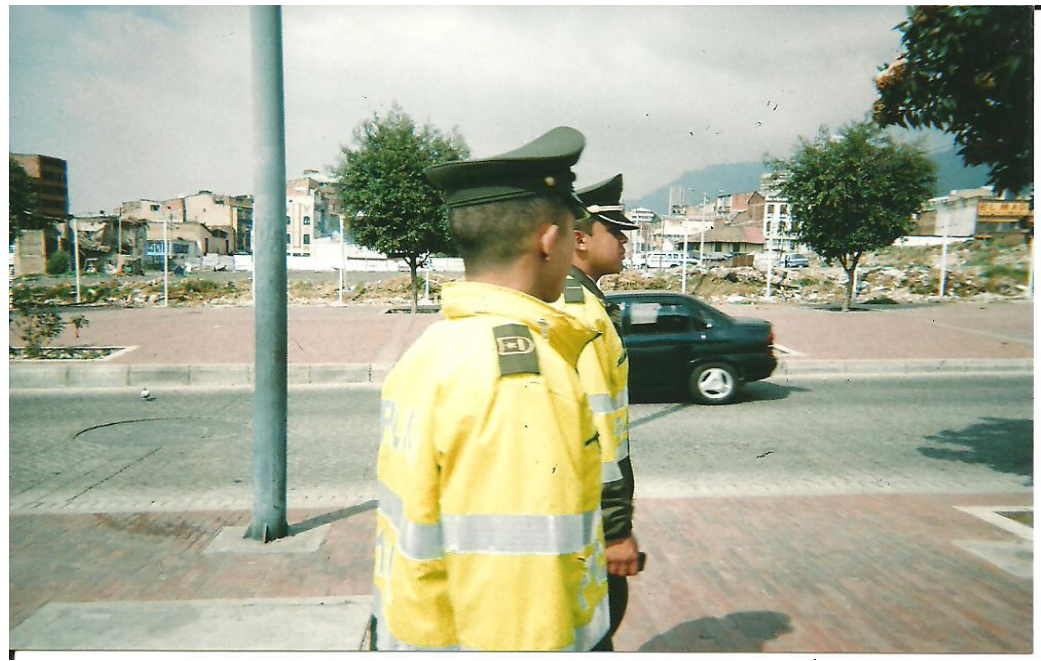


We passed the Caracas Avenue and Blue took a photograph of the Military Barracks in front of la 'L.' Most passersby in Transmilenio, taxi or car have no idea what lies behind the army building and rifle-carrying guards in camouflage fatigues.

\section{Photograph 5.5: La 'L' - Military Barracks}

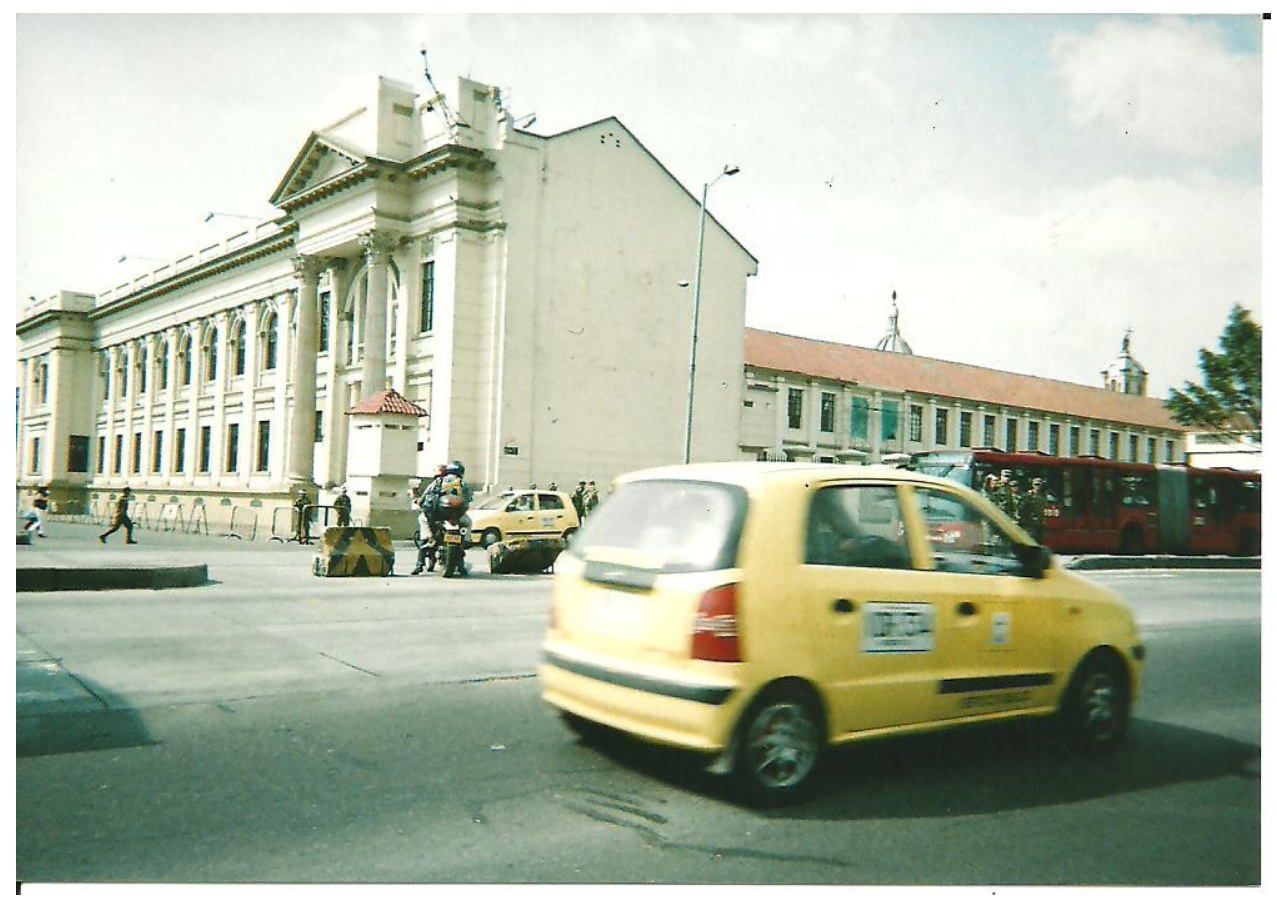

Passing the barracks, Blue walked ahead of the group more discretely to

photograph the entrance of la ' $\mathrm{L}$ ', which she snapped quickly and ran to hide in one of the wholesale blanket and curtain stores just past la ' $\mathrm{L}$.' 


\section{Photograph 5.6: La 'L' - South Entrance}

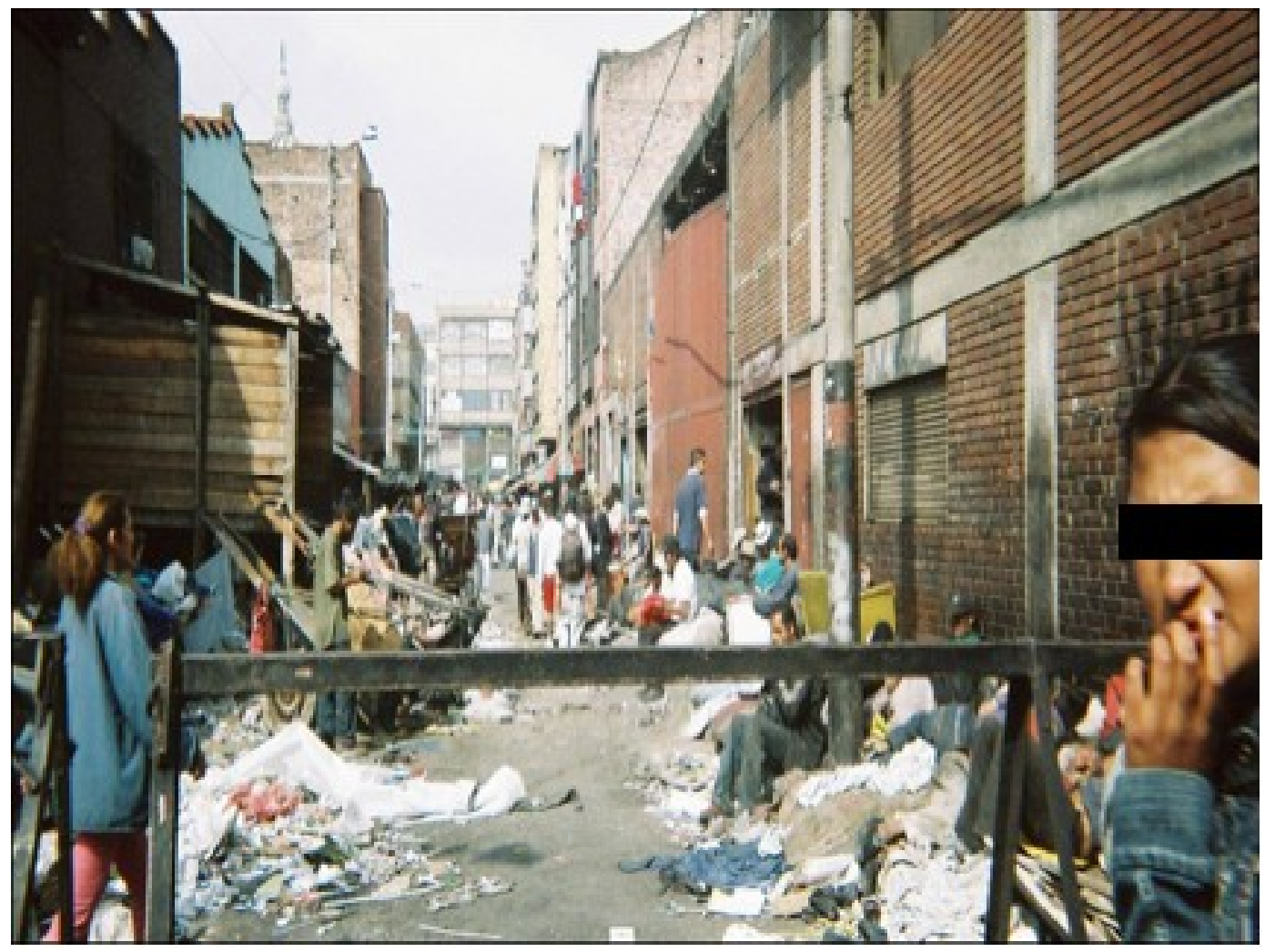

For safety, the rest of the group joined her there and we waited five minutes before continuing the roving focus group. The girls in the Mariposa Subgroup tend to avoid la ' $\mathrm{L}$ ' as macabre stories from their peers have frightened them away. One such tale is that the dead, from overdose, failure to pay a debt or a dispute with a jivaro (drug dealer), are cut up and their bones ground to powder to mix with the bazuco sold in la 'L.'

In reference to these urban legends, Biscocho marked la 'L' as a dangerous space on her map with a large knife symbol and talked about her fear of los sallas, saying: "Los sallas...son los que manejan todo el la 'L'...hasta los mismos jivaros, viciosos, viciosas, locos, locas...los manes andan super bien vestidos ...un grupo armado...cada vez va creciendo mas...este es el terrorismo que hay en la ' $L$ '...en la ' $L$ ' hay trabajadoras 
sexuales pero ellas trabajan por la droga de ellas o a veces por los sallas ...(Los sallas... are the ones who run everything in la ' $L$ '....even the dealers, users, and crazies...the guys are super well dressed [they are]...an armed group...steadily growing more...this is the terrorism of la ' $\mathrm{L}$ '....in la ' $\mathrm{L}$ ' there are sex workers but they work for their drugs or sometimes for 'los sallas')” (Biscocho, Exploratory Interview, January 29, 2010).

In her exploratory interview, she described the current wave of social cleansing killings as an example of this type of terrorism, saying: "Este mundo nunca va a estar limpio ni de prostitutas ni de ladrones ni de indigentes... si nos damos cuenta cada vez es peor...todos somos seres humanos...(This world will never be free of prostitutes nor thieves nor beggars...if we really look at it, it is always getting worse...[but] we are all human beings)" (Biscocho, Exploratory Interview, January 29, 2010).

Biscocho also marked la 'L' as a public place, laughing: “claro...es público...en la 'L' entra cualquier [persona] ...todo es público ...[pongo] una flor grande (Of course!...it's public....anyone can go into la 'L'...it's all public...[so I'll put] a big flower)" (Biscocho, Mapping Interview, April 27, 2010). She explained the choice of this symbol as: “...una flor ...por los parques...me gusta pasar tiempo alli (...a flower...because of the parks...I like spending time there)" (Biscocho, Mapping Interview, April 27, 2010).

In the research population overall, 'public' is one of the categories most frequently chosen to represent la 'L.' Sixteen research actors marked la 'L' as a public space where they spend time. Seen through their eyes it is certainly public, as anyone 
may enter. For the vast majority of Bogotá residents, however, this area is seen as in no way public but a private, impenetrable, and lethal hell-hole (Niño et al., 1998).

Biscocho was the principal research actor of the Mariposa Subgroup that suggested El Parque Tercer Mileno as the location for interviews with the girls who were not part of her gang and who she did not want to invite to her apartment in La Victoria. She preferred public spaces for the interview context and, for example, her mapping interview was conducted in a cafeteria on 10th Avenue with 19th street. This was farther from the Mariposa than other public interview locations. She specifically requested this as she was fighting with her girlfriend at the time and did not want to be found or seen by any of her Mariposa peers.

\section{Photograph 5.7: YPAR Roving Focus Group}

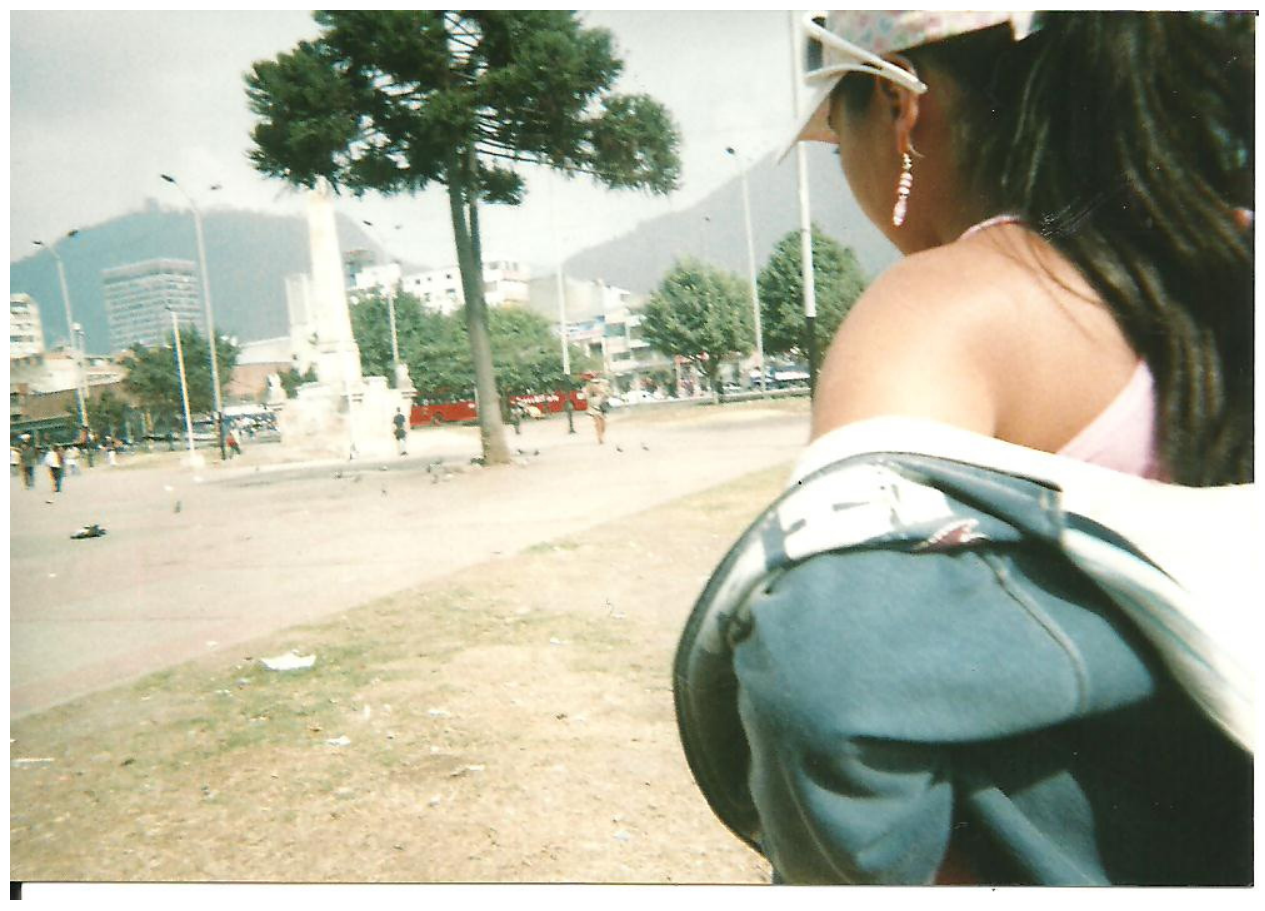

After Biscocho determined that no 'L' figures had seen us with a camera, we continued the roving focus group and left the blanket and curtain store. La Costeña 
starting recalling her days of living and trasnochando (staying up through the night) in la 'L.' As we walked, I asked questions about the most important places for her when she spent time in la 'L.' Bareques (shacks with couches in the la 'L' open air drug market) were the first places she mentioned. In response to this, and catching on quickly to YPAR methodology, Biscocho requested that la Costeña take photos of a bareque during her auto-photography week.

\section{Photograph 5.8: Inside la ' $\mathrm{L}$ '}

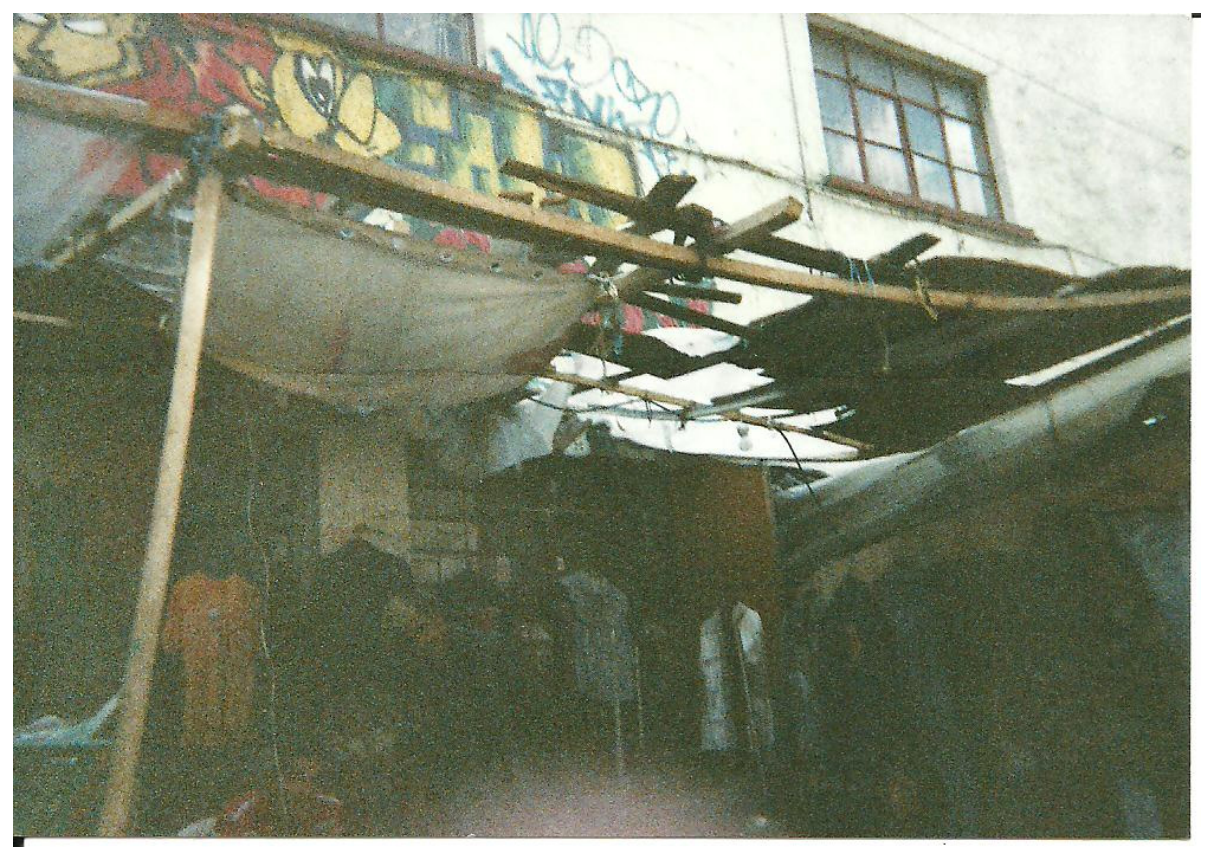

Similar to the discussion of her urban journeys through the center of Bogotá during her exploratory interview, La Costeña described her days in la ' $\mathrm{L}$ ' while we circled around it. In her mapping interview, La Costeña emphasized her perception of la ' $\mathrm{L}$ ' as a public space and described her 'public' symbol as “...mucha gente...muñequos chiquitos...muchos en la ' $L$ '...(...lots of people...little doll [symbols]...lots in la ' $L$ ')”' (La Costeña, Mapping Interview, April 27, 2010). 


\section{Map 5.5: La 'L' as a Public Space}

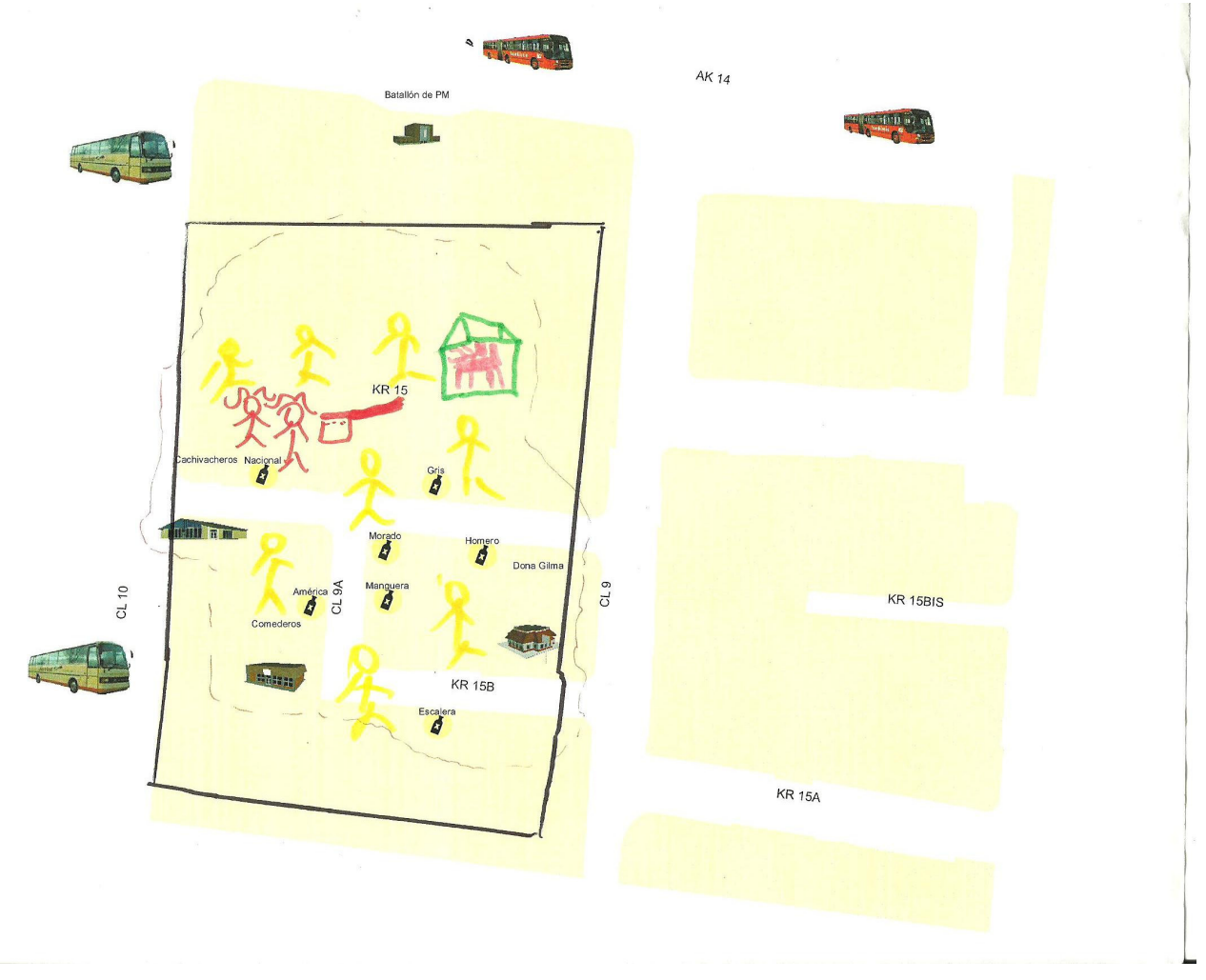

While La Costeña visualized the 'public' aspects of la 'L' through images of many people packed in bareques and rockolas, Victoria illustrated 'public' through images of drug paraphernalia as she sketched multiple symbols of a bareto con humo (joint with smoke) and a pipa de bazuco (crack pipe) on the corners where she used to smoke bazuco and marijuana. In response to the question, "Is la 'L' public?" she responded, "Si...pasaba tiempo...en Gris...vea...un bareto con humo...y hagamos una pipa en Homero...y y hice la pipa ...yo solo fumaba Homero y Gris...(Yes...[it's public]...I used to spend time in Gris [a dealing/using location]...look... a joint with smoke... and let's put a pipe on Homero [another dealing/using location])" (Victoria, Mapping Exercise, March 31, 2010). 


\section{Map 5.6: La 'L' - Other Perceptions of Public Space}

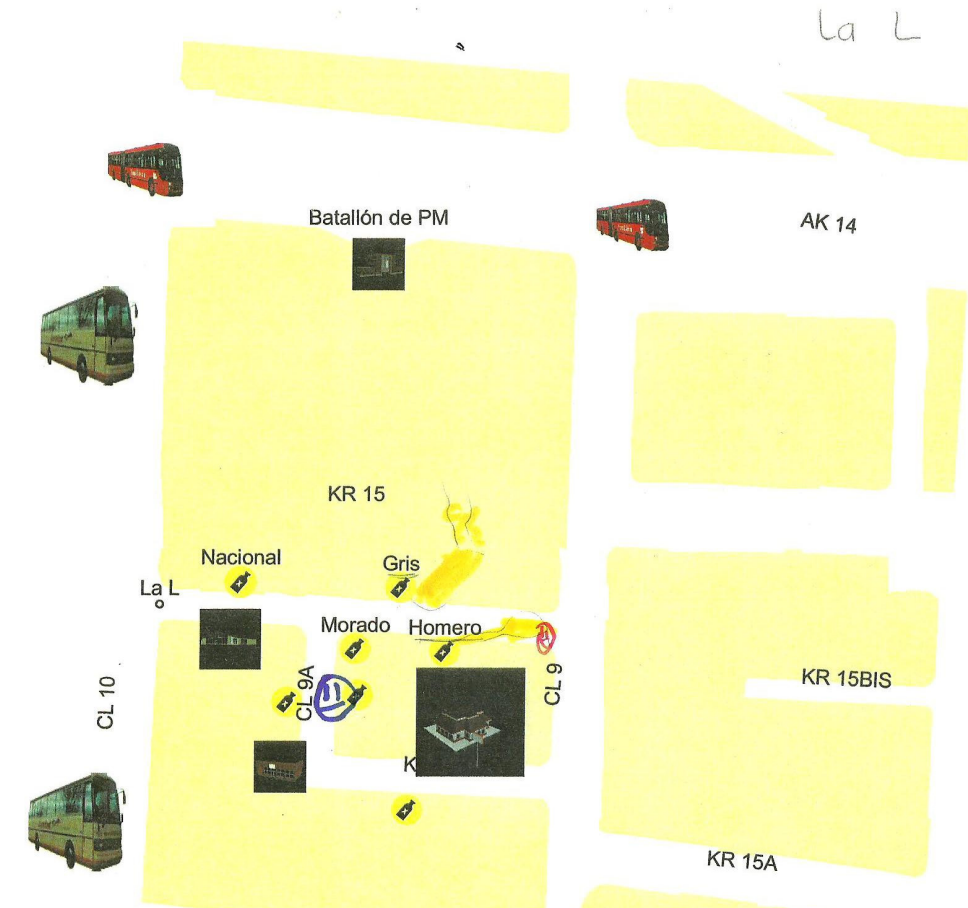

During her mapping interview, La Costeña marked la Mariposa with blue condom symbols to indicate 'work' spaces and when asked if she worked in la ' $\mathrm{L}$ ' emphasized with revulsion: “huiii nooooo, no, no (ewww, noooo, no, no)" (La Costeña, Mapping Interview, April 27, 2010), and explained that she only did drugs and spent time with friends in la 'L.' She added that she would never work in la ' $\mathrm{L}$ ' because it is dangerous, the clients are repulsive, and she prefers to work in la 'Maricosa', as she calls it, and return for drugs in la ' $\mathrm{L}$ ' with money obtained elsewhere.

Despite the dangerous and horrifying conditions, there are, however, girls who work in la ' $\mathrm{L}$ ' in direct exchange for drugs or for minute sums of money, used immediately to exchange for drugs. Very similar sex-for-drug exchanges and 
concomitant risks have been described in ethnographic studies of U.S. crack use (see, for example, Inciardi 1993).

Six research actors marked work spaces in la 'L.' Victoria noted: “...he hecho ratos en la ' $L$ '... un día hice un rato con un salla...con el salla de Manguera...donde esta la entrada de los Martires...hice un rato con un salla aca atras... me sentia mal...son varios sallas de Homero y varios sallas de Gris...se visten bien ... estos se disfrazan ...yo la pasaba en Gris soplando (I've turned tricks in la 'L'...once I did a trick with a salla...with the salla from Manguera...near the entrance from the Martires plaza...I did a trick with a salla back here [pointing]...I felt bad ...there are several sallas in Homero and several in Gris...they dress well...those guys disguise themselves [smartly]...I spent my time blowing drugs in Gris)" (Victoria, Mapping Exercise, March 31, 2010).

While mapping out her daily urban journeys on the general map, La Costeña traced the following movements between the El Samber, la Mariposa, and la 'L' study sites: “Bueno... mi recorrido es...vivo en la ' $L$ '... me levanto a las 7 de la mañana y cojo la ruta en la salida de la 'L'.... para patios [en el Samber] ... salimos a las cuatro de la tarde...[y] me voy para mi sitio de trabajo...que es la Mariposa ... me hago un rato, dos ratos...que dependiendo pues el cliente donde quiere pagar la pieza...en la Escalinata o en el Diana...voy a las dos...de allí bueno me hago dos, tres ratos...y me voy otra vez para la 'L', pago un día de pieza, dos días de pieza ...y después voy a Nacional ....a comprar bolsitas...y de alli a veces cuando me aburro del mercado allí... voy hasta El Samber y allá compro los 5 gramos...(Well...my route [urban journey] is...I live in la 'L'...I get up at $7 \mathrm{AM}$ and catch the program bus on the way out from la ' $\mathrm{L}$ '... to go to the day center [in El Samber]...we leave there at 4 PM...[and] I go to my 
workplace...which is la Mariposa...I turn one trick, two tricks... which, depending on where the client wants to pay for the room, maybe in la Escalinata o el Diana...I use them both...from there, well, I may do two or three tricks... and I go back to la 'L,' I pay one or two nights rent and then I go to Nacional...to buy baggies [of bazuco]...from there, sometimes when I get tired of the market there, I go to El Samber and there I buy 5 grams [of bazuco])" (La Costeña, Mapping Interview, April 27, 2010).

The mapping interview excerpt illustrates how and why la ' $L$ ' is both a 'central' place in her daily life (in which drug use is the central factor orienting her geographies), and a space where she spends time with 'friends.' She chose to represent 'friend' spaces with “unos muñequitos y una pipa...solo en la 'L' y en la Mariposa (little dolls and a pipe [symbols]...only in la 'L' and la Mariposa)" (La Costeña, Mapping Interview, April 27, 2010). When describing the symbol for 'central', La Costeña said, "lo encierro en un circulo....la Maricosa...y mi pieza [en la 'L'] ...porque si no tengo pieza, ¿ donde vivo? ...en la calle...por eso la encierro...(I put a circle around it...la Maricosa [Word play]... and my room [in la 'L'] ...because if I don't have a room where do I live?...in the street...that's why I circle it )" (La Costeña, Mapping Interview, April 27, 2010). Overall, eight research actors indicated that la ' $\mathrm{L}$ ' is a central space in their daily lives. Marking the location of her pieza with a green house symbol (for the 'not public' category) and enclosing a pink person relaxing on a bed (for the 'safe' category), $L a$ Costeña explains that her pieza is not a public place (about the only non-public place in la ' $\mathrm{L}$ ' for her) and that her piezas in both la ' $\mathrm{L}$ ' and Las Cruces (where she lived previously) were the only places she felt safe in the city. She outlined all spaces in la ' $L$ ' with a black square (for the 'unsafe' category), "porque todo es inseguro menos mi 
pieza...(because everything is unsafe except my room)" (La Costeña, Mapping Interview, April 27, 2010). La Costeña's map of la 'L' demonstrates the temporary nature of 'feeling safe' for street girls and that temporary living conditions do not necessarily constitute home. When asked to mark places she feels at home, she noted: "Ya en ningún lado...ni siquiera en mi pieza porque desconfío... de todos lados y peor de la ' $L$ ' (Now nowhere...not even in my room because I distrust... [everyone] in all places and worse in la 'L'” (La Costeña, Mapping Interview, April 27, 2010). Following the 'home' category, she marked her family's home on the coast of Colombia as a space of exclusion and drew a “...muñeco triste y tachado (...a sad doll with a slash mark)" (La Costeña, Mapping Interview, April 27, 2010). She was laughing but her body language clearly showed sadness.

Although La Costeña lives in la 'L,' she does not feel at home there. Six research actors, however, indicate spaces of 'home' in la 'L.' While marking la ' $\mathrm{L}$ ' as a public (asterisk for 'public') and more comfortable space for her than la Mariposa, Darly notes that “...yo prefiero irme a la 'L' y fumar bareta tranquila alla en una bareque y no estar en la Mariposa ... que visaje con los tombos encima de uno...(...I prefer to go to la ' $\mathrm{L}$ ' and smoke grass quietly there in a bareque and not stay in the Mariposa... what a drag with the cops all over you)" (Darly, Exploratory Interview, June 4, 2010). In addition to seeing la ' $\mathrm{L}$ ' as a safe haven from police, la ' $\mathrm{L}$ ' for Darly is a place she associates with 'home,' especially in la Escalera (marked with an orange joint symbol), a place that is 'central' in her life (marked with a brown heart,) and a 'public' place (marked with a large asterisk, indicating that all places in la ' $\mathrm{L}$ ' are public and accessible for her). It is a place where she socializes and has her closest friendships, represented by a large, red 
smiling face over the three blocks of la 'L.' While carefully sketching the symbols of her la 'L' map, she enjoyed drawing her 'friend' spaces and said, “...en la 'L' es una barraquera ...espere...vea como hago los ojos...una sonrisa...las pestañas...esta viene siendo como yo...y los aretes...(...[being] in la ' $\mathrm{L}$ ' is the best...wait... look how I make the eyes...the smile...the eyelashes...this is beginning to look like me... and the earrings...)" (Darly, Mapping Interview, June 4, 2010).

\section{Map 5.7: $\mathrm{La}$ ' $\mathrm{L}$ ' as Social Space}

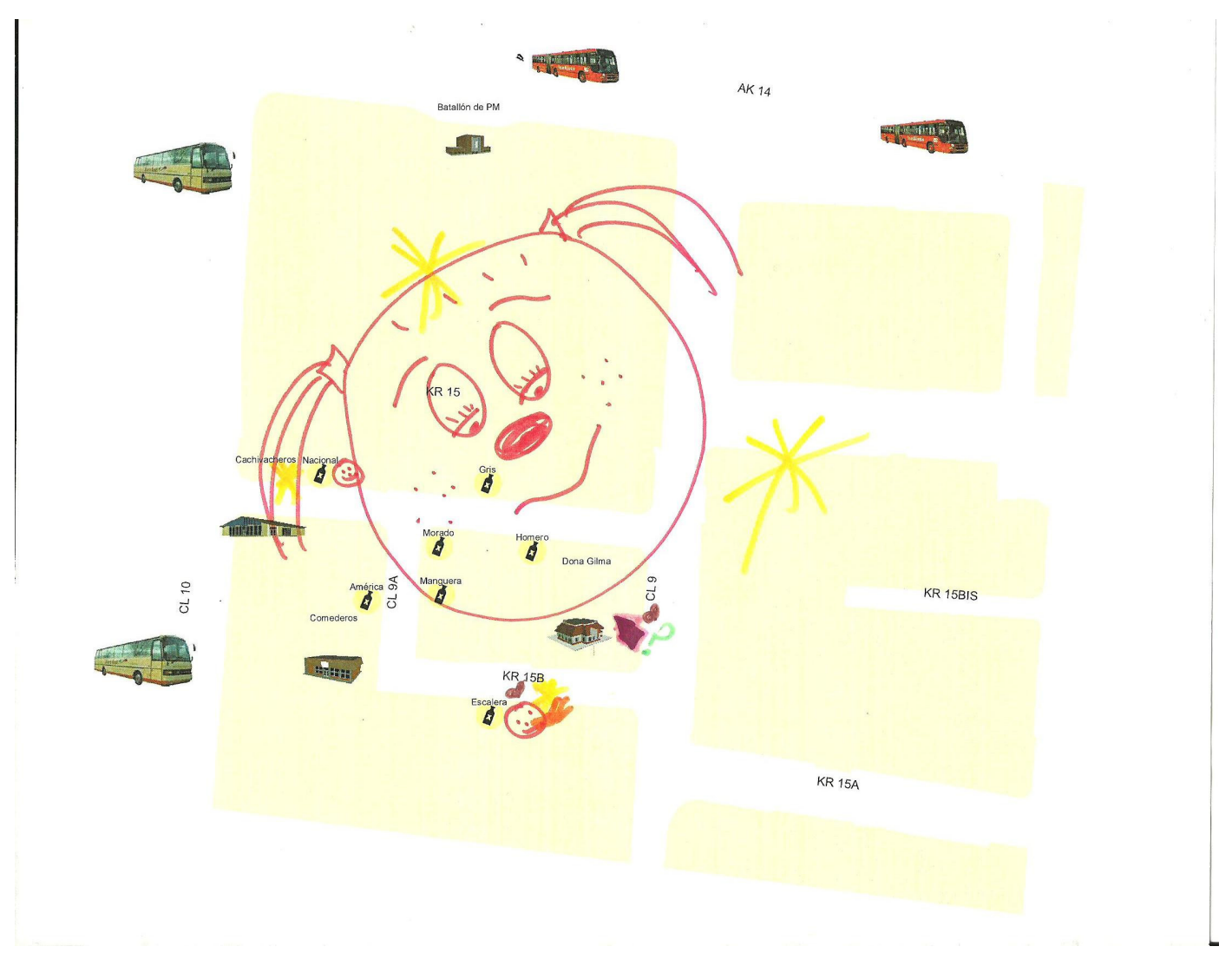

For Darly, who is very much part of the la ' $\mathrm{L}$ ' inside, la ' $\mathrm{L}$ ' is not a dangerous space but rather a safe space, marked with a pink house over her favorite olla. While working on her la 'L' map, Darly had a huge smile on her face and the exercise clearly provoked positive place memories associated with her favorite rockolas and 
bareques. Angela also illustrated feeling comfortable and at home in la 'L' by drawing the symbol of a CD to represent her 'home' spaces on the map. She noted feeling at home in la 'L' "...por la música ...la música ... [un CD] para las rockolas claro...(...because of the music...the music...[a CD symbol] for the rockolas, of course..." (Angela, Mapping Exercise, June 24, 2010).

For other girls, however, la ' $\mathrm{L}$ ' is a space of exclusion in which they have experienced violence and rejection. Four research actors indicated spaces of exclusion in la 'L.' As described by Victoria in her discussion of exclusion in the exploratory interview:

Los sallas...cuando echaba pegante [en la 'L'] ...me pegaban también por echar pegante...porque el pegante es una competencia para el bazuco...está prohibido...y paila ... y a ellos no les conviene porque pierden clientes...que le quitan el tarro y lo echan en la cabeza...un día yo estaba así echando pegante... un salla volteó a mirar y ya no lo vi...cuando lo vi fue encima mío...saca la cacha ... y, booomm! me pega por acá un cachazo...un revolver me pego en la cabeza...cuando me entraron en una rockola y me dieron un palazo acá... y un cachetada ...en la ' $L$ ' no se puede ni robar...ni echar gale...ni pelear...[puedes estar]...en una rockola...eche, eche pipa y ya... escuchar música ... a mi no me gusta hablar con nadie...es que ni compañeros allá... allá lo venden a uno hasta por un pipazo...no confiar en nadie...(...Los sallas...when I was huffing glue [in la ' $L$ '] ... they beat on me as well for doing glue...because glue is competition for bazuco...it's banned... and you're screwed...it's no use to them because they lose clients...they take the bottle from you and pour it on your head...one day I was doing glue like that... a salla turned to look and I didn't notice him... when I did see him he was already on to me...pulls out his piece... and, booomm! he whacks me across here with a pistol butt...I was hit in the head with a revolver...then they pulled me into a rockola and hit me with a stick and slapped me in the face ... in la 'L' you cannot steal...nor do glue...nor fight... [you can only be] in a rockola ...puff, puff on the pipe and that's it...listen to music...I don't like talking to anyone... you can't even have friends there...they will sell you just for a pipe full...you can't trust anyone...) (Victoria, Exploratory Interview, March 31, 2010). 
For Sentimientos Ocultos, la 'L' represents nothing more than exclusion. Her only symbol in la 'L' was a large, purple 'sad face' over the entire three-block span of la 'L.' When asked to indicate her spaces of exclusion, she said: “ [pongo] una cara triste donde no me siento comoda ...en la 'L'y en la Mariposa... [¿ien qué lugares en la ' $L$ '?] ...EN TODO...me siento incómoda en todo lado de la ' $L$ ' ([I put] a sad face for where I don't feel comfortable...in la 'L' and the Mariposa... [which parts of la 'L'?]...EVERYWHERE...I feel uncomfortable in every part of la 'L')" (Sentimientos Ocultos, Mapping Interview, May 8, 2010).

\section{Map 5.8: La 'L' as a Space of Exclusion}

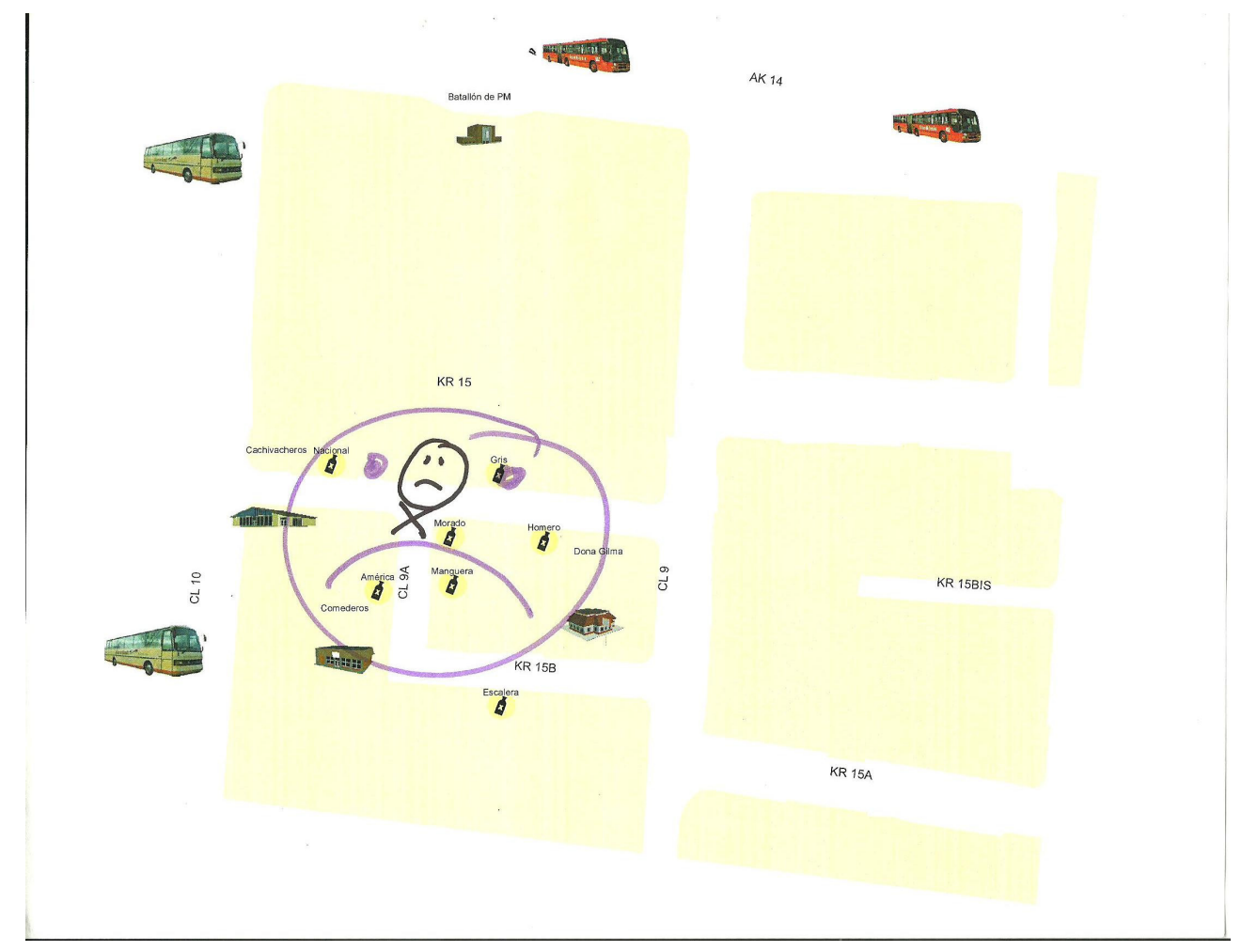

These geo-narratives describing street girls' activities and perceptions of places in la 'L' emphasize that there is life and activity in these spaces that the local planning department tries to smooth over, both in the project images and, eventually, in the 
construction of new public spaces. In contrast to this official narrative, many of the girls, both while sitting in El Parque Tercer Milenio for interviews with the Mariposa subgroup, and in interviews with girls in the Mariposa/L subgroup, mentioned that El Parque Tercer Milenio is, or feels like, a cemetery, both for its bleak, windy emptiness and for the cold, concrete surfaces covering what is now the corpse of El Cartucho. Biscocho notes that she gets the chills when she walks through it to la Mariposa or la 'L.' Smoothing Over Barrios: What Lies Between El Samber and Las Cruces

\section{Map 5.9: Urban Renewal in El Samber and Las Cruces}

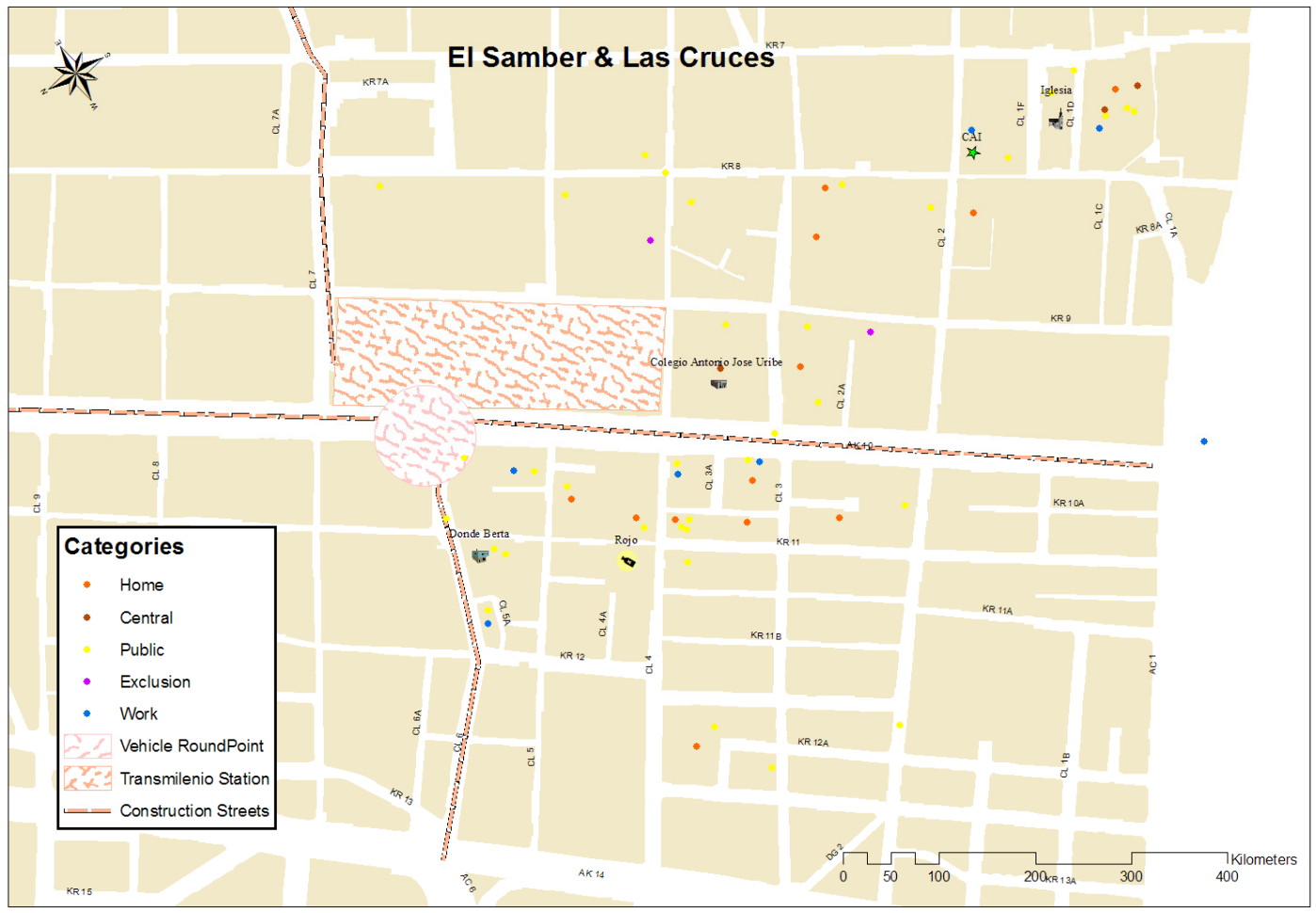

Map 5.9 visualizes the urban renewal projects currently underway between and within

Las Cruces barrio and El Samber. Street girls' activity spaces according to five spatial variables (home, central, public, exclusión, and work) are also shown in the map in order 
to illustrate the proximity of street girls' everyday spaces to urban improvement projects.

Satanás describes urban 'improvement' efforts in El Samber and Las Cruces:

\section{Photograph 5.9: Satanás in El Samber}

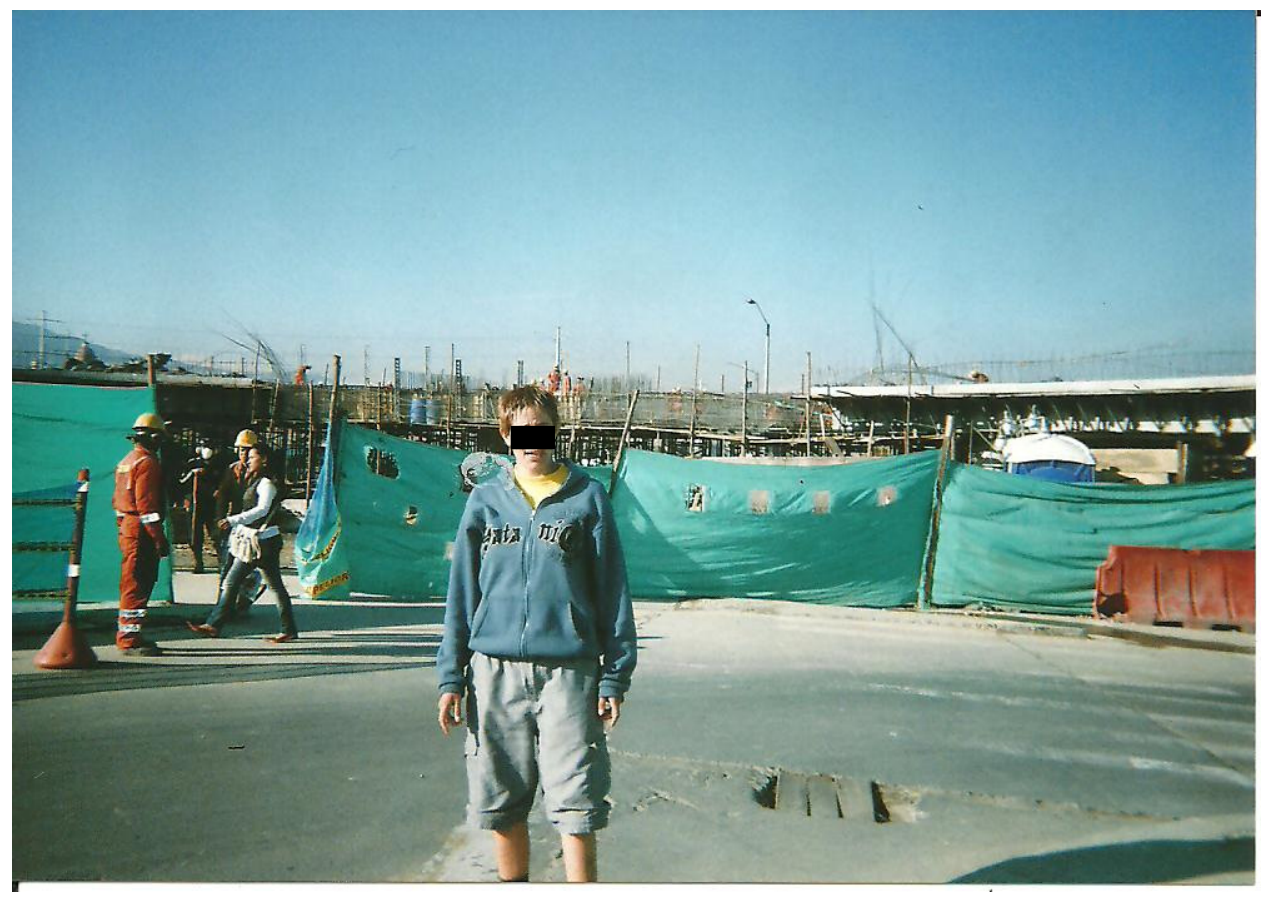

...El IDU [Instituto de Desarrollo Urbano] comenzó a comprar casi todo... a algunos les tocó vender a la fuerza a otros se les despojó de los terrenos que ellos tomaron a la mala...te acuerdas de esas casas que te mostré por donde Chola [en El Samber] ...en unos tres años ya no vas a ver nada por allí... el IDU compró todo e igualmente tendrán que venderlas, y sino por espacio publico tendrán que demolerlas... Bueno y cuando nos terminaron de sacar de la olla nos fuimos hacía el San Bernardo en la calle 3 con carrera 12...de alli he vivido en casi todo el San Bernardo...conozco desde la sexta hasta la Antigua sexta, Las Cruces, el Cinco Huecos, Santa Fé... Luego me fui a la 'L' ...lo que quedo reducido a la calle del 'Bronx' en donde se juntaron el resto de personas que quedaron del Cartucho... Después...estuve viviendo en el barrio Las Cruces...alli viví casi como tres meses... luego llegamos otra vez al San Bernardo viviendo en la 4 con 4 ...Y de alli al lugar en donde estamos viviendo ahora que es el 3 con carrera 10A [en el Samber]...(...The Urban Development Institute began to buy almost everything... some people were forced to sell ...others were evicted from land they had occupied... Do you remember those houses I showed you by Chola's drug house [in El Samber]...in three years time, you won't see anything left there...the Institute bought everything .... and there is no choice but to sell to 
them....and to open up spaces, they will have to demolish

them...OK... and when they had succeeded in expelling us from the dope zone....we moved to San Bernardo, $3^{\text {rd }}$ Street with $12^{\text {th }}$ Avenue...from then I've lived all over San Bernardo...I know everywhere from sixth street to the old sixth street ... Las Cruces, Cinco Huecos, Santa Fé... then I moved to la ' $\mathrm{L}$ '... what remained of 'the Bronx' and where the people left over from the Cartucho went...then I was living in Las Cruces barrio...I lived there almost three months...then we arrived again to San Bernardo living on $4^{\text {th }}$ Street with $4^{\text {th }}$ Avenue... and from there to the place where we are living now which is $3^{\text {rd }}$ Street with 10A [in El Samber]...) (Satanás, Exploratory Interview, March 31, 2010).

\section{Photograph 5.10: Satanás in the Streets of El Samber}

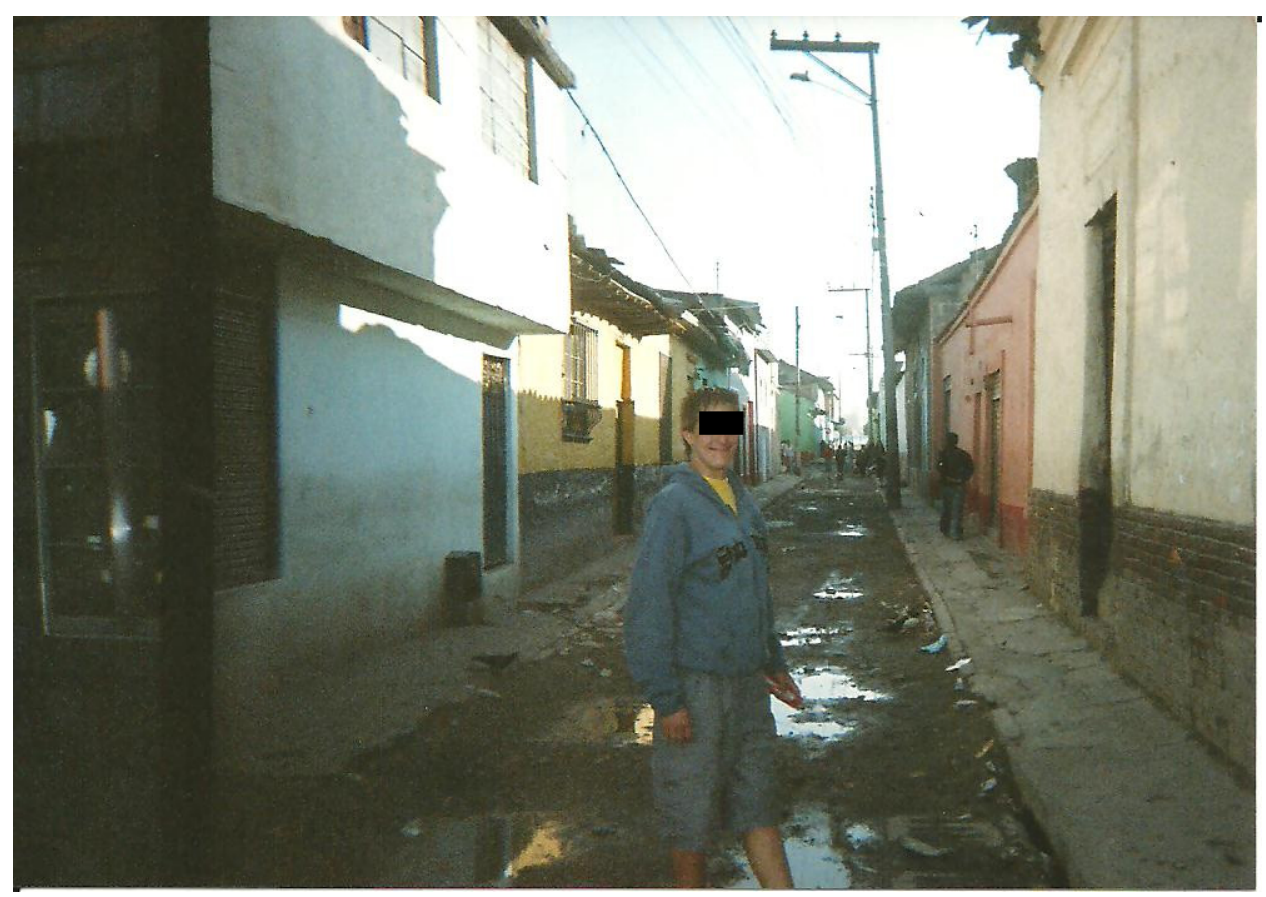

In this further discussion of her experiences of forced movement between El

Samber and Las Cruces, the geographies of Satanás reflect a pattern of displacement over more than three years in both study sites. 


\section{Photograph 5.11: Satanás on 10th Avenue}

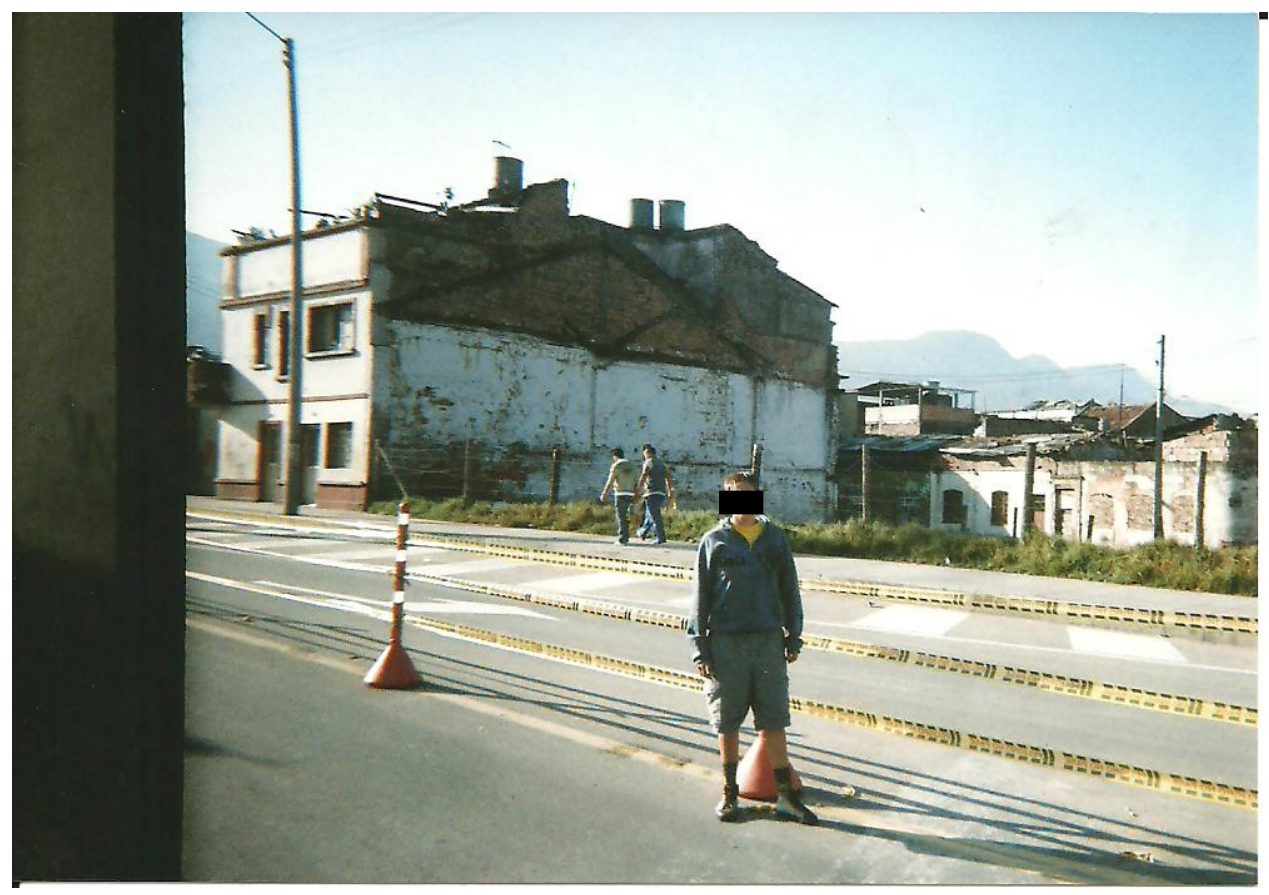

The changes in these barrios have also affected the everyday lives of other research actors, including El Cilencio and El Guapo, both Mariposa/'L' Subgroup leaders and active participants in YPAR writing workshops.

They were mourning the death of a close friend from El Samber (high on glue, but as it is now impossible to enter El Samber without crossing high speed traffic complicated by construction of a new bridge, she was hit and killed by a bus). When asked her opinion regarding the changes already under way because of Transmilenio construction, El Cilencio noted:

Otra urbanización a base de vidas...vidas de personas que no encontraron otro camino fuera de la drogaddición para creerse o sentirse una persona más...otro 'mejoramiento' en la ciudad sin tener en cuenta la opinión de todas las personas que habitan en este lugar ...un carril nuevo encima de muchas personas que no tuvieron la más mínima oportunidad de ser reubicados en otros lugares...no tuvieron otra forma de subsistir sino como todo el mundo lo llama una olla ... acaben con este lugar basta para formar un nuevo lugar en la ciudad pero no se detienen un momento para 
pensar en que todas estas personas podrian ser utiles en lo que ellos le llaman una 'Bogotá Positiva'...que no le importa matar o quitarle derecho de vida a personas que no pertenecen a un estrato social alto...la pregunta seria 'Será que matando o ocultando la realidad de Bogotá podían llamarle una Bogotá Positiva?' ... 'Será que un drogadicto de corbata sería señalado o juzgado de la misma forma que un habitante de calle?' ... 'Matarías o acabarías con un espendidor de drogas de estrato alto como lo hacen con los de estrato bajo?'... 'Harías un Tercer Milenio en un Congreso de la Republica si alli vendieron drogas como lo hicieron con el Cartucho?' (Another urban development costing lives...lives of people who could find no way other than drug addiction to believe or feel that they are a person....another 'improvement' in the city without taking into account the opinions of everyone living in this place... a new highway on top of many people who were never given the slightest chance to be relocated...they never had the chance to survive anywhere else but in what is known as a drug hole...ending this place, for them, is enough to form a new place [but] they don't stop for a moment to think of how all these people could be useful in what they call a 'Bogotá Positiva' [municipal PR slogan for a 'positive' city]... or that they don't care about killing or taking away the right to life of people who do not belong to a high social stratum...the question should be, 'Can killing or hiding the reality of Bogotá be called a positive city?'...'Would a collarand-tie drug addict be stigmatized or judged in the same way as a street person?'...'Would you kill or do away with a drug dealer from a high social class as they do with those from a lower class?'...'Would you build a [El Parque] Tercer Milenio on the Congress if there drugs were sold like they did with the Cartucho?') (El Cilencio, Participatory Writing Workshop, January 3, 2011). 


\section{Photograph 5.12: Urban Improvement Slogan}

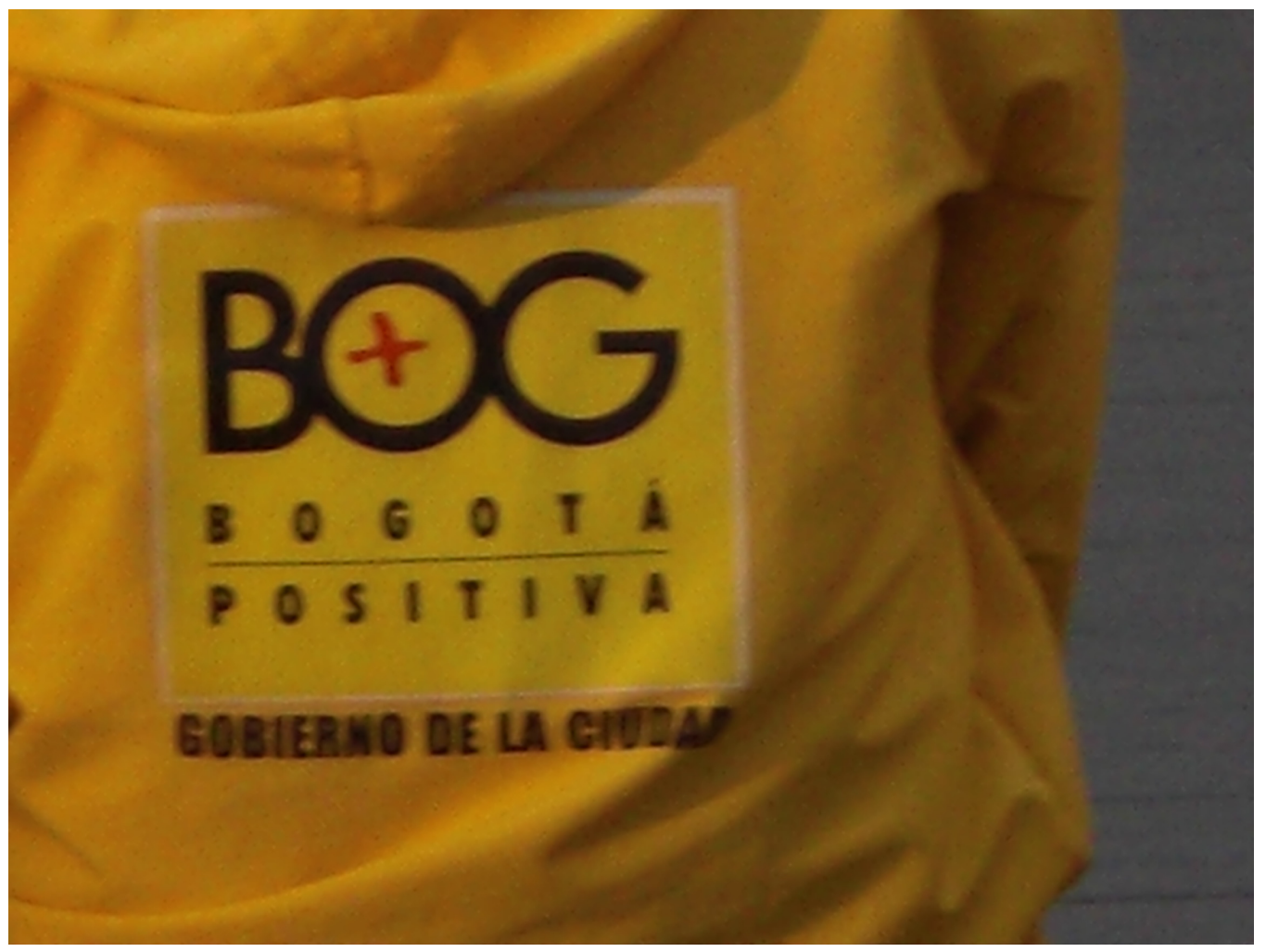

The purpose of including the description of street girls' perceptions of El Samber and Las Cruces and their experiences within these two study sites is to emphasize that there is life and activity in these spaces that the local planning department smoothes over in the project planning images. See Image 5.4 below, depicting the vision of what will lie between and eventually smooth over El Samber and Las Cruces. 


\section{Figure 5.3: Project Planning Image}

TRANSMILENIO FASE III

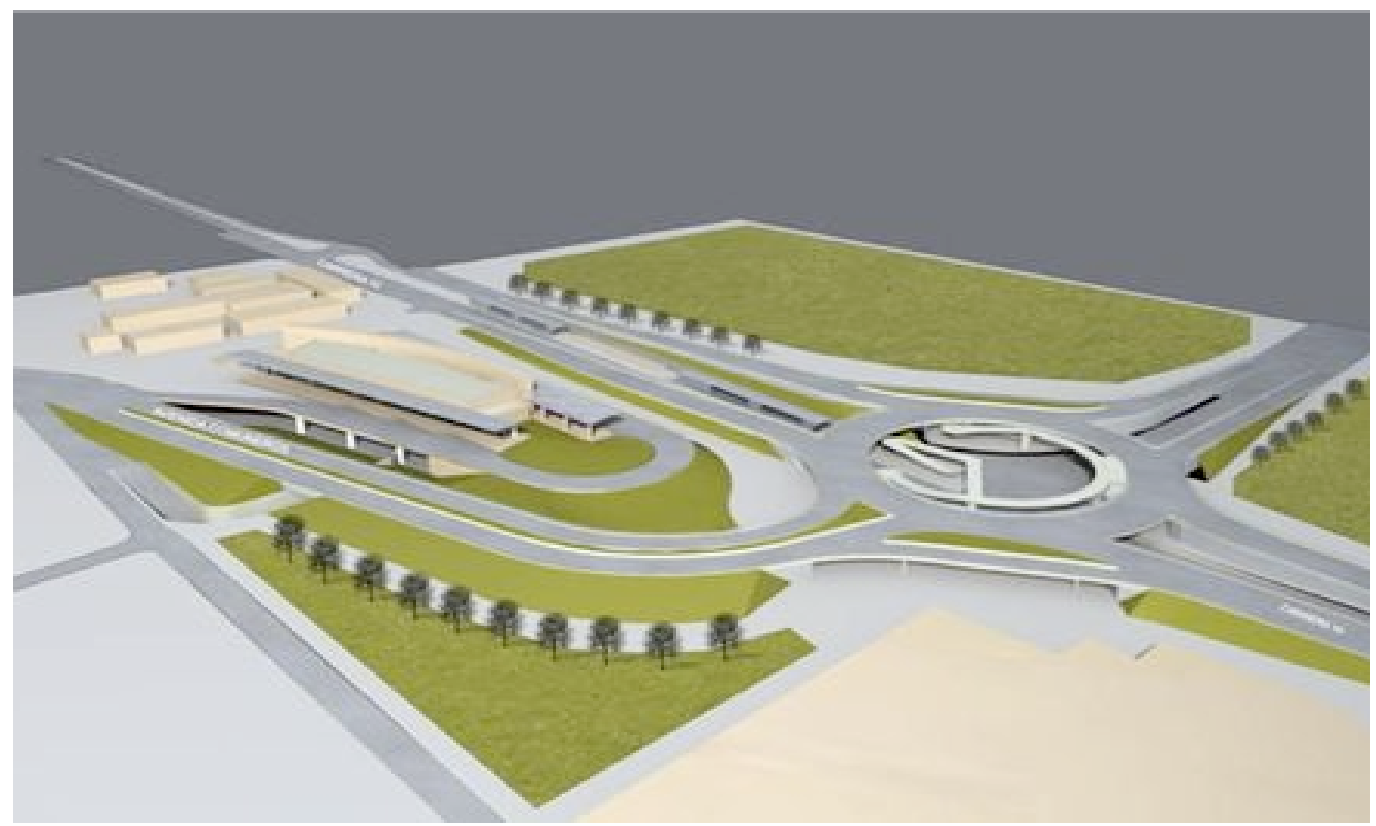

Estación Intermedia calle sexta

Con un área de $2.500 \mathrm{~m} 2$. la estación contará con 8

plat aformas de alimentación, otras 8 para servicio

de buses intermunicipales.

An elaborate, eight-platform, inter-municipal Transmilenio station is being built on the edge of Las Cruces barrio and a three-level roundabout with new Transmilenio connections is being constructed on the edge of El Samber

(http://www.idu.gov.co/web/guest/construcciones_tm_f3 frente_estclsexta, accessed February 1, 2011). The IDU planning department image smoothes over both spaces and has already begun to change the face of both study sites. As noted in Satanás' interview narrative of El Cartucho, El Samber has already been significantly reduced and will disappear as quietly and quickly as El Cartucho. 
Putting the 'ACTION' in YPAR: Re-claiming Urban Space

In reaction to these urban renewal efforts and during our first YPAR seminar at Universidad de los Andes entitled "Iniciativas de Desarrollo Urbano y Exclusión SocioEspacial de las Jóvenes en el Centro de Bogotá (Urban Development Initiatives and Socio-spatial Exclusion of Female Youth in the Center of Bogotá)", the girls performed a rap song they composed during a YPAR "Hip-Hop for Change" workshop regarding urban development, the plans to smooth over El Samber, and reflections on the spatial cleansing of El Cartucho and its remains (la 'L'). The lyrics included below, demonstrating research actors' place attachments to areas such as El Samber and la 'L,' call for a reflection on the urban renewal projects that eliminated El Cartucho and are in the process of eliminating El Samber and Las Cruces.

Canción (Song): “Un Parque no Cambia la Realidad (A Park Doesn't Change Reality)”

"Pensaron que con matar tratar de acabar o quizás esconder la cruda realidad Aqui mucha gente viene a pasear/sin Importarle los cuerpos que allá están Excluidos olvidados sin pensar que la ' $L$ ' Los iba a reemplazar.

Dicen que la droga la quieren acabar Sabiendo que políticos sacando su tajada Están. No soy universitaria tampoco de la High/soy una chica que no oculta la Realidad/merecemos una voz/ un espacio En la sociedad (They thought that killing would maybe hide the hard reality Many people come and stroll Without caring about the bodies Excluded, forgotten, not thinking that la ' $\mathrm{L}$ ' Will replace them

They say they want to stop drugs Knowing that the politicians who get their cut are right there I'm not a college student nor from the upper crust I'm a girl who doesn't hide the truth 
We deserve a voice, a space in society)."

Coro (Chorus):

"No...No...No drogas...

No dañes El Samber por favor

No...No....No drogas...

No dañes tu vida por favor

No...No....No drogas...

No dañes tu ciudad por favor

No...No...No drogas...

No dañes tu mundo por favor

(No...No....No drugs...

Don't damage El Samber please

No...No... No drugs...

Don't damage your life please

No...No...No drugs...

Don't damage your city please

No...No... No drugs...

Don't damage your world please)."

"Pasar por El [Parque] Tercer Milenio antes Cartucho

es como pasar por el cementerio/lleno de

Almas y de muertos, donde hubieron muchas

Victimas y muchos desconsuelos.

Sino no tomas conciencia y te pones a pensar

Que en vez de ignorar tu puedes ayudar a

Que lugares como El Samber y la 'L' se puedan

Recuperar y mejorar

(Walking through the [El Parque] Tercer Milenio

That used to be El Cartucho

It's like walking through a cemetery

Full of souls and bodies

Where there were many victims and much mourning

If you don't wake up and begin to think

That instead of turning a blind eye you can help

Places like El Samber and la 'L'

Recover and get better)."

Coro (Chorus):

"No...No...No drogas...

No dañes la ' $L$ ' por favor

No...No...No drogas...

No dañes tu vida por favor 
No...No... No drogas...

No dañes tu ciudad por favor

No...No....No drogas...

No dañes tu mundo por favor

(No...No....No drugs...

Don't damage la 'L' please

No...No...No drugs...

Don't damage your life please

No...No....No drugs...

Don't damage your city please

No...No...No drugs...

Don't damage your world please)."

Autores y Cantantes (Authors and Rappers): El Cilencio and Sentimientos Ocultos

\section{Photograph 5.13: Hip-Hop for Change - Action Research Presentation}

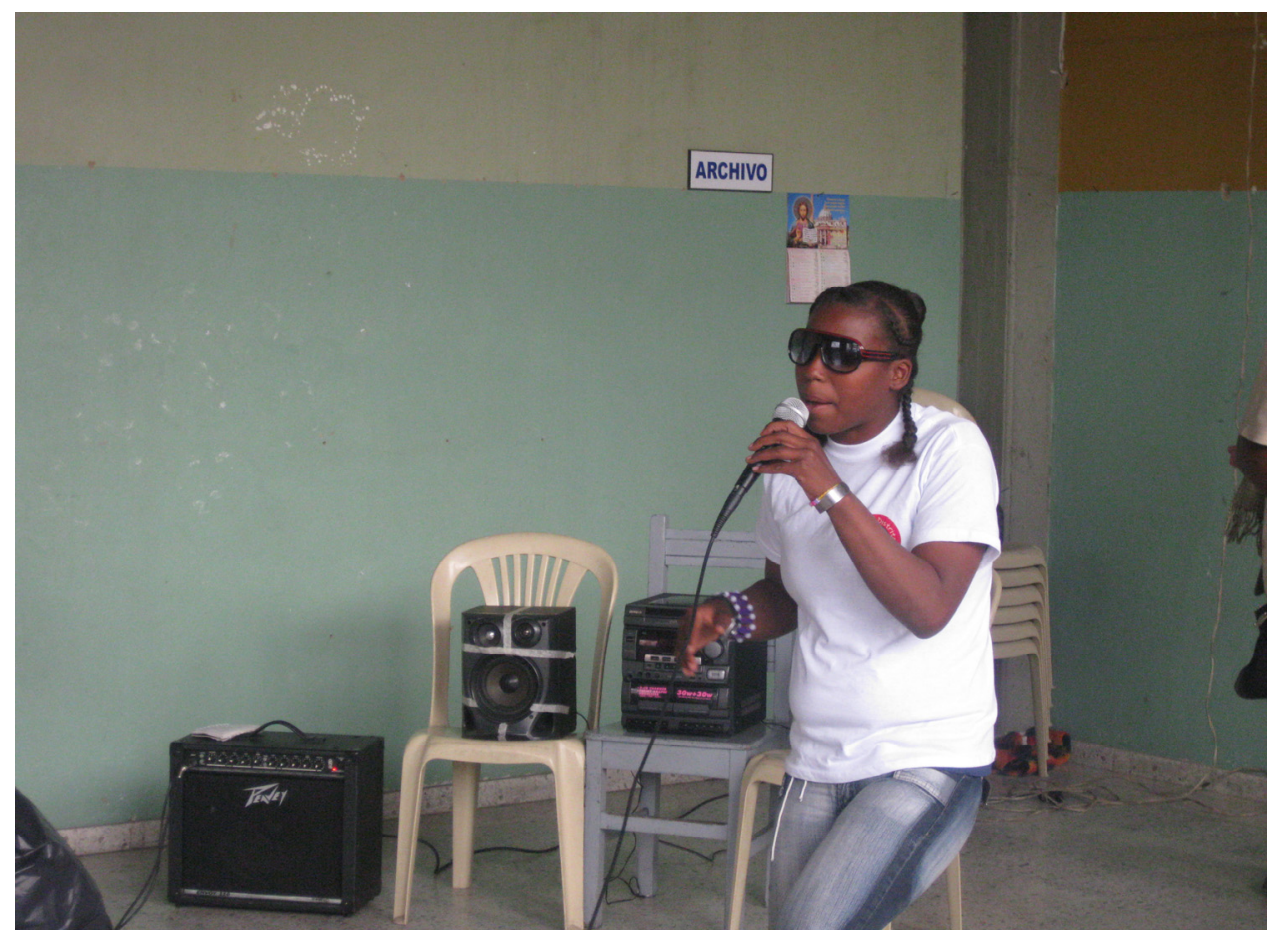

During each YPAR presentation in which 'El Parque no Cambia la Realidad' was presented, the girls showed pictures and videos that the YPAR team produced to depict the current state of the two zones and explain how their lives have been affected. 
Most street girls, from both the Mariposa and Mariposa/'L' Subgroups, who live or have previously lived in El Samber and Las Cruces, have noticed changes in the barrios since the 'improvements' in the area began.

\section{$\underline{\text { Photograph 5.14: Re-claiming Las Cruces }}$}

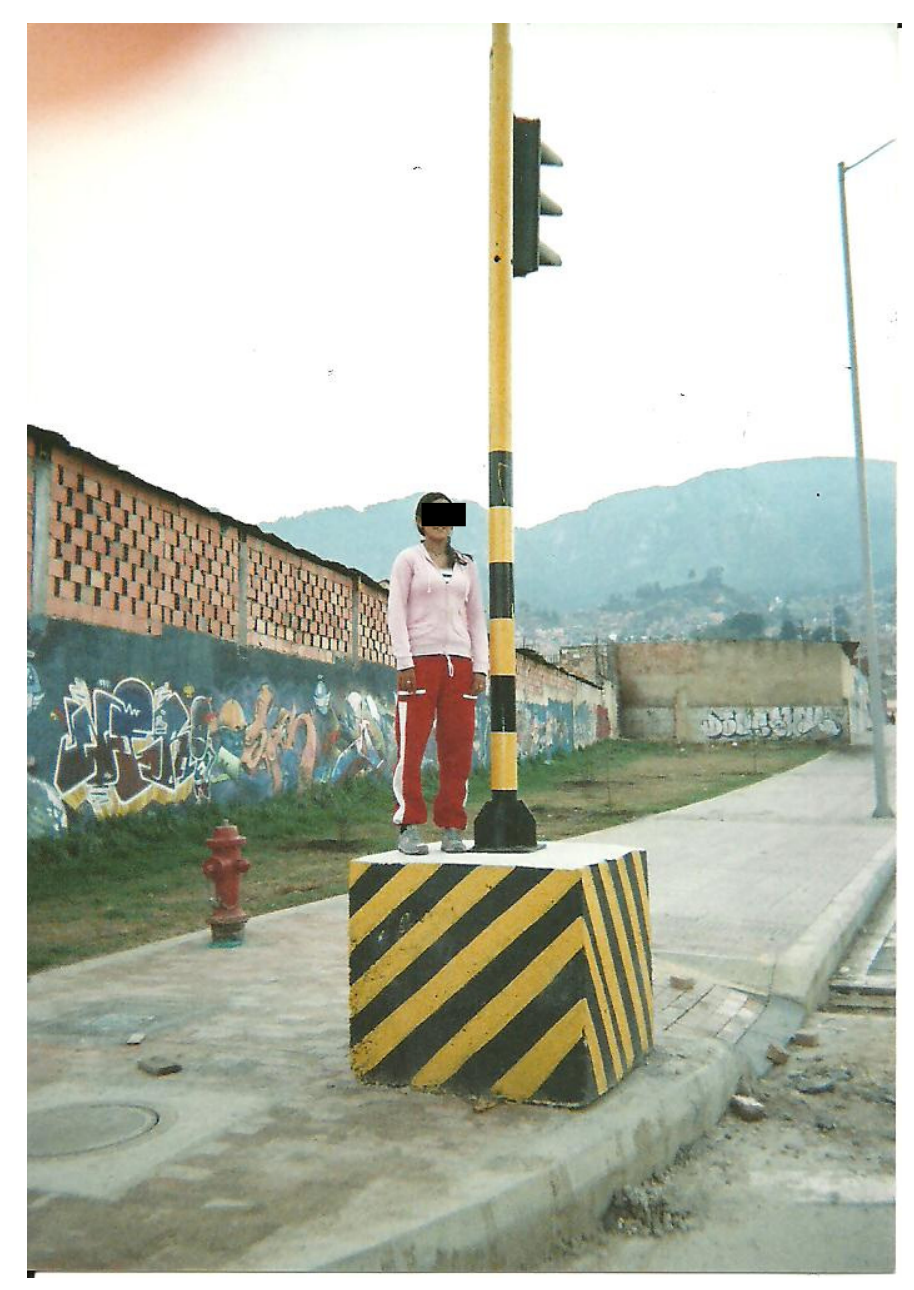

Victoria, for example, remembers moving to Las Cruces to live with some of her friends in an area farther away from la Mariposa than her previous room in another barrio, La Favorita, seven blocks east of la Mariposa. However, she notes, the environment became more hostile and she decided to move back to La Favorita after a violent incident with the police behind the $C A I$ (police station) of Las Cruces. When 
answering the question as to what people she associates with feelings of rejection or exclusion, she stated: “...los tombos...nadie más...me han pegado, me han dado bolillazos, me han dado hasta cachetadas en la cara...una vez en el parque de Las Cruces (...the cops ... no-one else ...they have hit me with night sticks...they've even pistol-whipped me in the face...one time in the Las Cruces park )" (Victoria, Exploratory Interview, March 31, 2010).

From la Mariposa to 'San Victorino Centro Internacional de Comercio Mayorista' Map 5.10: La Mariposa - Activity Spaces and Urban Renewal

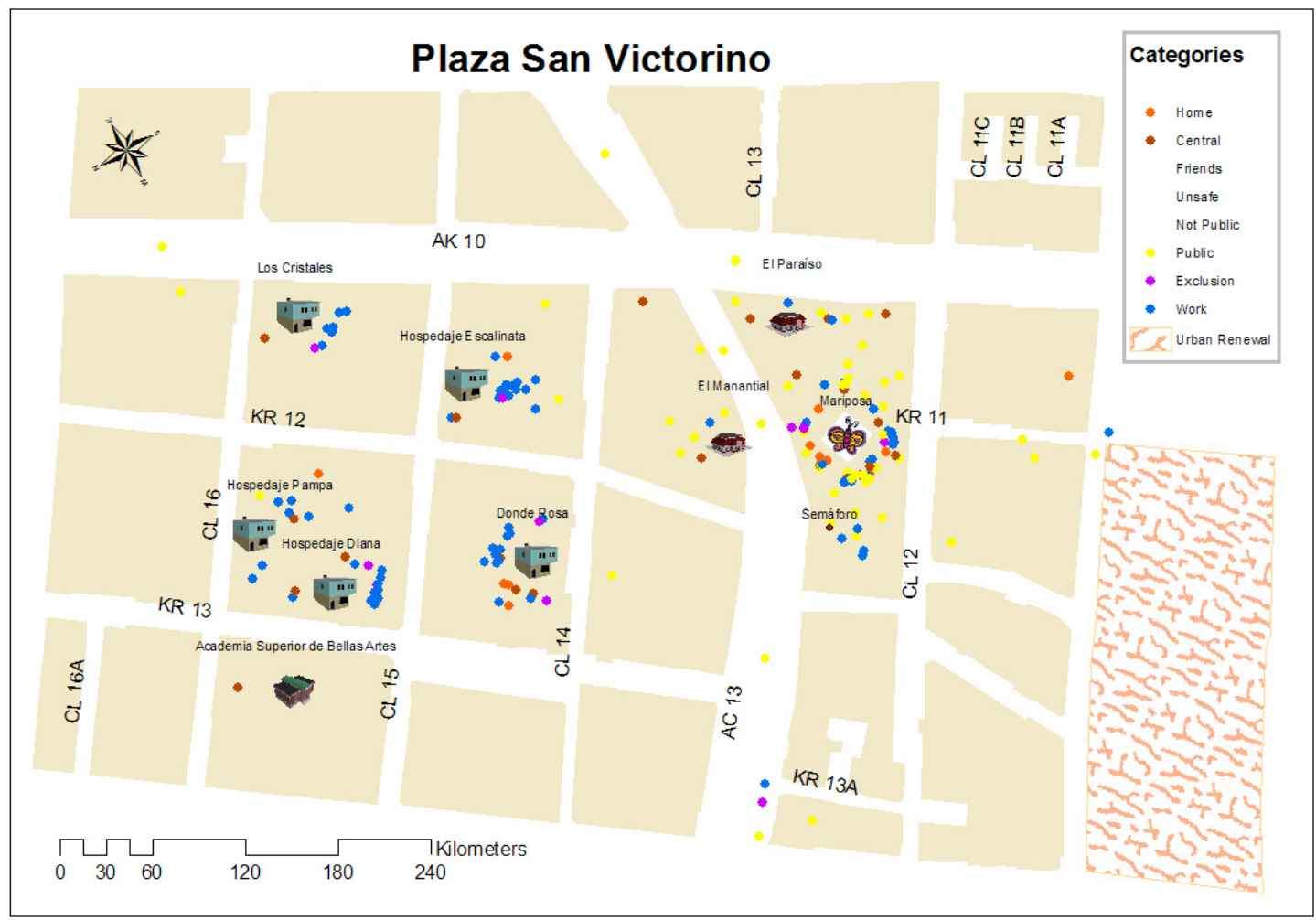

The same five spatial variables (work, public, central, home, exclusion) were used to construct Map 5.10 for the la Mariposa study site. Twenty-five research actors across all three subgroups marked at least one of the five categories used for analysis within the Mariposa study site indicating that la Mariposa is an important and central space for 
street girls. Twenty-one out of 25 research actors marked la Mariposa as a 'work' space, 25 out of 25 marked la Mariposa as a 'public' space where they spend time, 17 out of 25 marked la Mariposa as a 'central' space, 10 out of 25 as a 'home' space, and 6 out of 25 as a space of 'exclusion.'

As a low-cost shopping area in the city center, la Mariposa is an obvious and official open public space, in contrast to la 'L,' which is hidden from public view and accessed by a much smaller and location-specific population. It is often precisely because of the public and visible nature of all activities in la Mariposa that some street girls feel uncomfortable, out-of-place or rejected as they wait for clients in sight of any and everyone. As Biscocho noted in her exploratory interview and mapping exercise when explaining her choice of a purple carita de rabia (an angry face) to represent exclusion in la Mariposa: “...ay, no sé...me he sentido rechazada en el punto de trabajo de la prostitución...la plazoleta...la gente juzga por lo que ve...y pues si me ven a mi hablando con un tipo o ven que yo de pronto entro a una residencia...juzgan y hablan y miran y critican ...y si, me he sentido rechazada...(...oh, I don't know...I have felt rejected in my prostitution work place...the square...people judge you for what they see... and so if they see me talking with a guy or see that I may enter into a [by-the-hour] hotel...they judge and talk and look and criticize... and yes, I have felt rejected)" (Biscocho, Exploratory Interview, April 27, 2010).

She explained the symbol by expressing that she felt angry when people stared at her and judged her in the plaza. 


\section{Photograph 5.15: The Spectacle of la Mariposa}

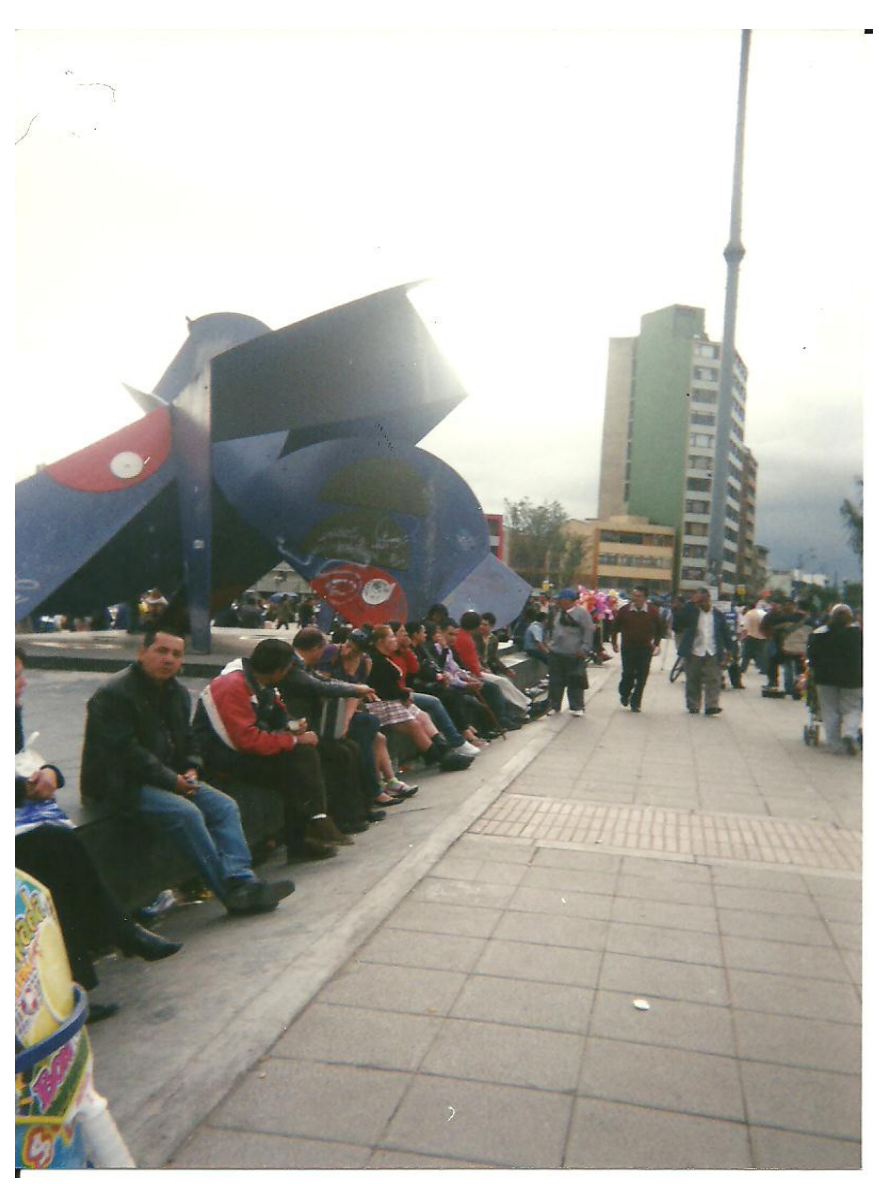

For La Costeña, her feelings of exclusion in la Mariposa stem from police forcing her out of the plaza. She described how: "Una vez me tocó dormir con una amiga en el parque de la Mariposa...pero hace mucho tiempo...y me sacaron...los tombos...que no podia dormir alli (Once I had to sleep with a friend in the Mariposa park...but this was a long time ago... and they kicked me out...the cops...said I couldn't sleep there)" ( $\mathrm{La}$ Costeña, Exploratory Interview, February 11, 2010). Harassment, detention, threats, extortion and sexual abuse are constantly reported by street girls and witnessed by activists in la Mariposa. While conducting a mapping interview, after another research actor described being beaten by a police officer while pregnant to the point that an 
ambulance had to be called and she was hospitalized, Sentimientos Ocultos expressed her own feelings about la Mariposa. She turned to me during the interview and while comparing la Mariposa to the often-cited dangers of la 'L,' remarked “...Ayyy mamita ... ¿tú crees que la Mariposa es segura para nosotras? (...Ohhh, girlfriend...you think la Mariposa is safe for us?) " (Sentimientos Ocultos in Darly, Mapping Exercise, June 4, 2010).

Photograph 5.16: La Mariposa and Authorities

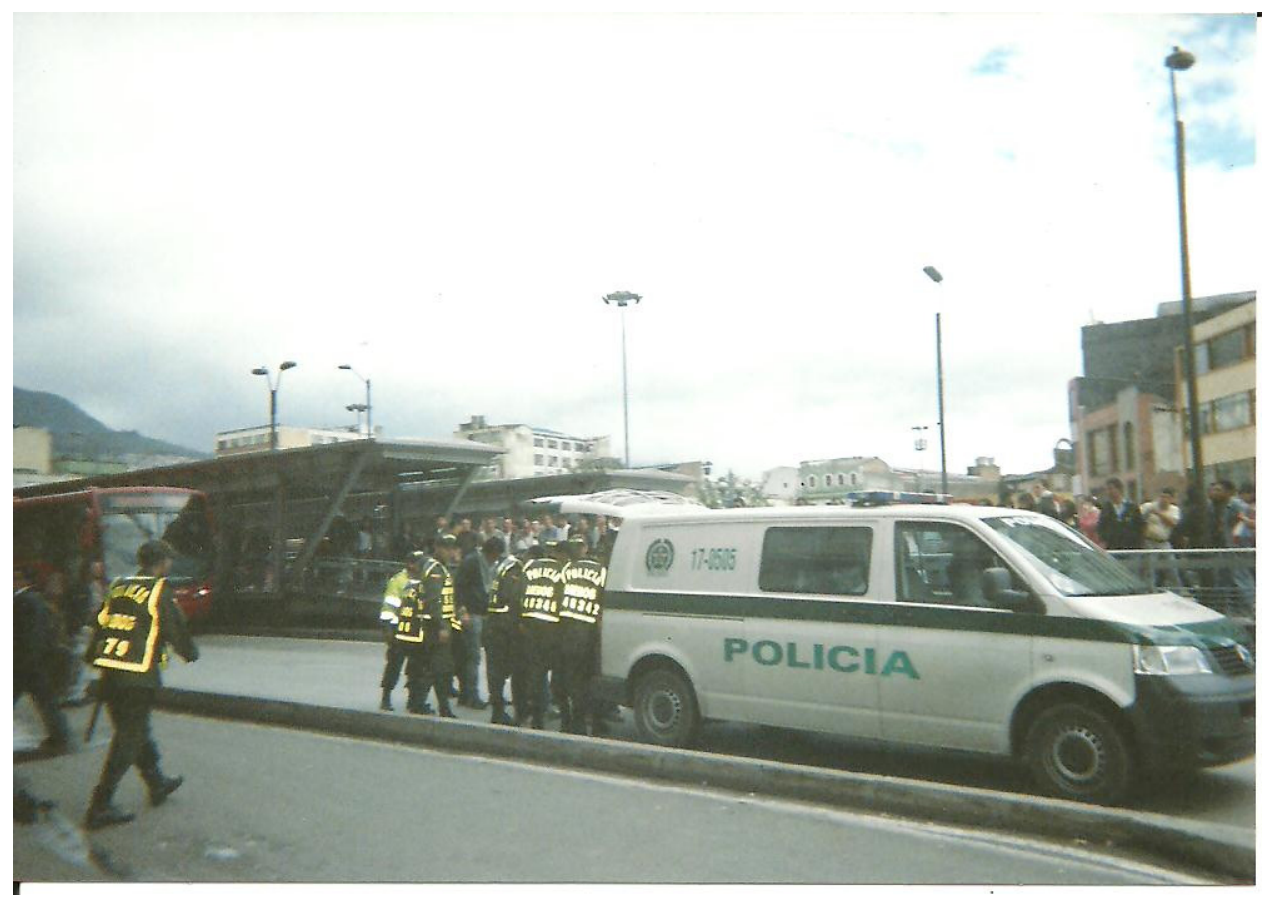

In contrast to Biscocho's discomfort and anger towards the gaze of passersby in la plaza, Julia marked la Mariposa as a 'central' space with two exclamation symbols signifying, she explained, admiration from others. It is the gaze of clients that determines her ability to eat and to pay for her room for that day. 
Photograph 5.17: Clients in la Mariposa

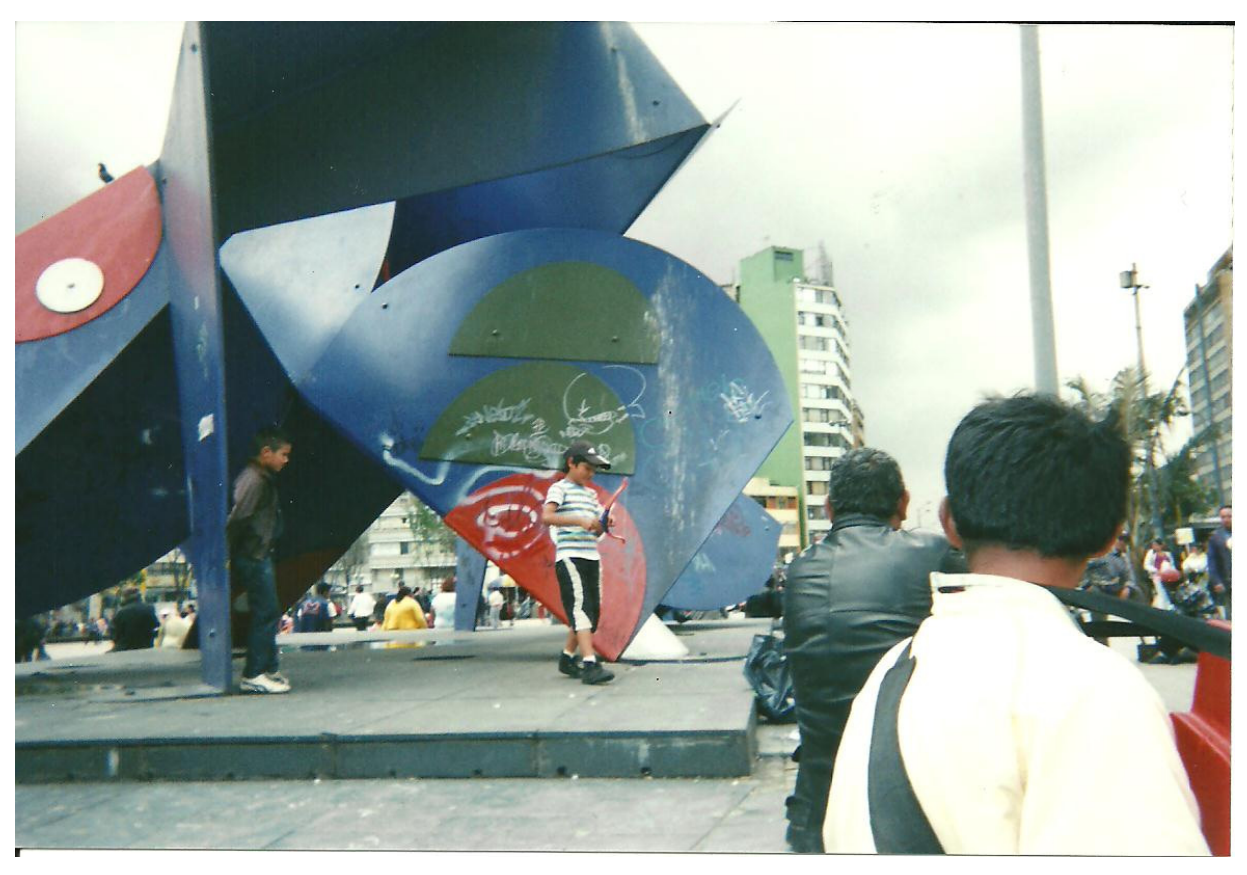

Map 5.11: La Mariposa as a Central Space

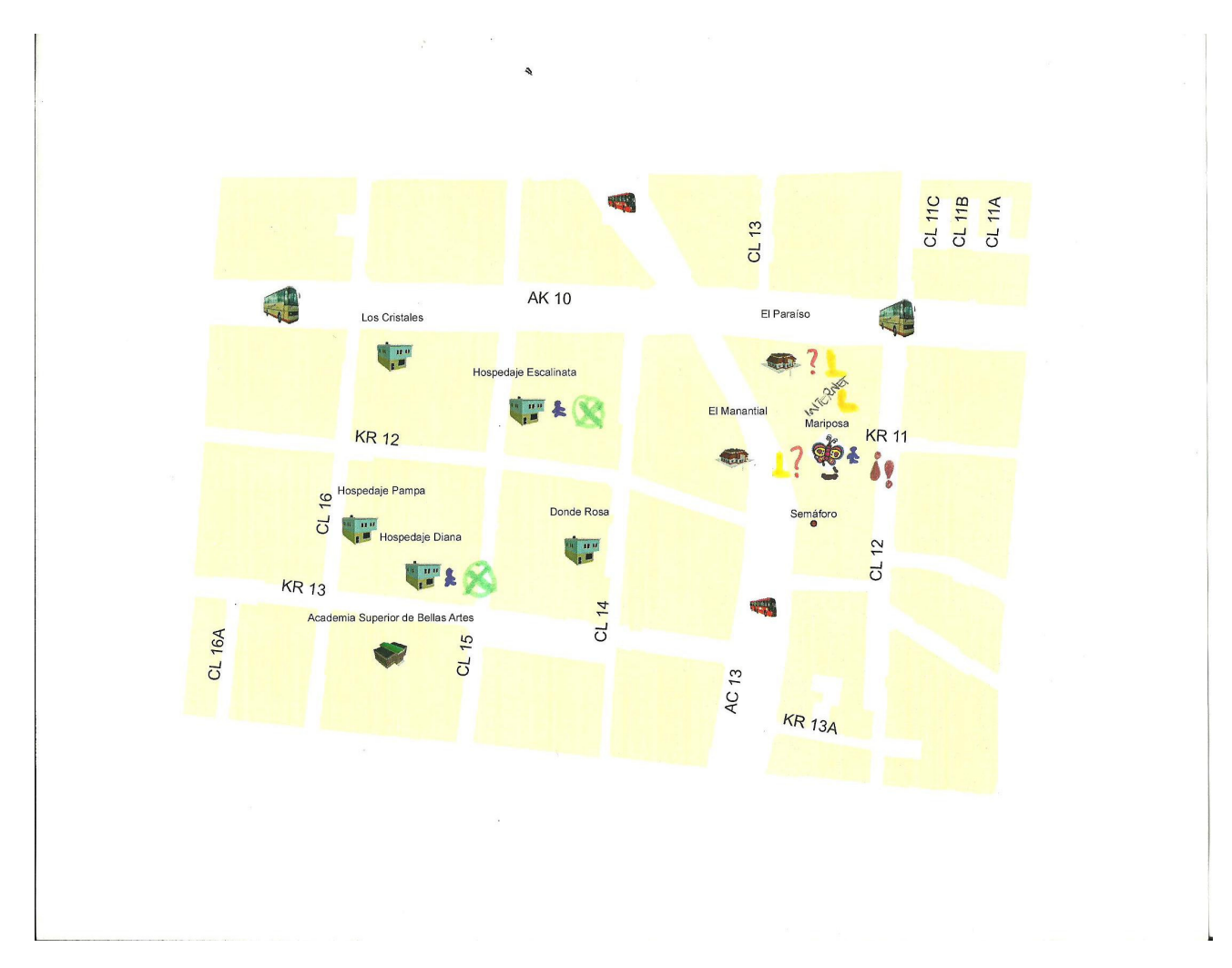


Similarly, El Guapo, who prides herself as being the 'looker' of the plaza, marks la Mariposa as a 'central' space, and all other important places in her daily routine (including the wholesale stores near the Mariposa and her room a few blocks away), with a mariposa (butterfly) explaining that both her income and urban journeys throughout the city start from or revolve around la Mariposa. Angela's urban journeys also originate in la Mariposa. In her mapping interview she described how: "Estoy en la Mariposa hasta que me salga un rato...después bajo por la ' $L$ '...paso la iglesia y entro por allí... [idonde has trabajado?] ...en la Nacional...en Puerta Negra...en Comedores...vendí comida...(I am in la Mariposa until I can score a trick...then I go down to la ' $L$ '...I go by the Church and enter there...[where have you worked?]...in la Nacional...in Puerta Negra ...in Comedores [Fast food, mostly restaurant left-overs]...I sold food there [in la 'L'])" (Angela, Mapping Exercise, June 24, 2010).

La Mariposa is the principal prostitution zone for the majority of street girls in the Mariposa and Mariposa/'L' subgroups and this is reflected in many girls' illustrations in the study site map. 'Work' spaces in la Mariposa are represented by, for example, symbols for sex acts, peso bills, doll figures in skirts, condoms, a man (representing a client), a pig (representing a client), and un polvo en el pasto (a screw on the grass). 


\section{Map 5.12: Multiple Meanings of la Mariposa}

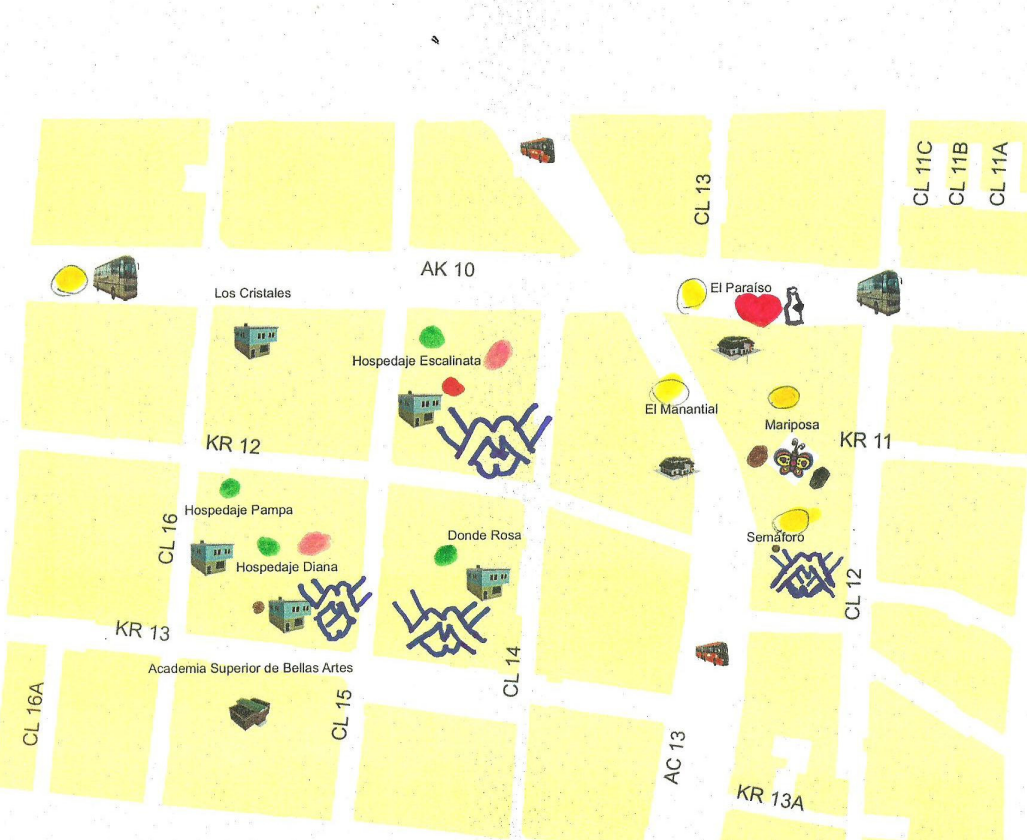

La Mariposa, given the plaza's diverse social and spatial meanings for street girls, represents something different for each girl. As stated by La Costeña when drawing a condom over the multiple spaces in which she works in the San Victorino zone, "Para trabajo...no seeee...coloco un preservativo...en la Maricosa...supuestamente es una mariposa pero yo le digo es como una cosa y no tiene forma...entonces es la Maricosa... [This phrase is an elaborate word-play, untranslatable from Spanish]" (La Costeña, Mapping Interview, April 27, 2010).

The Plaza San Victorino is much more than just a commercial center and plaza for street girls. With the destruction of hundreds of open-air, cheap wholesale stores and an extreme shift in the people and political interests controlling the public space, la Mariposa, as street girls know it, will no longer exist. La Costeña described the feeling of 
comfort and familiarity felt when she arrives in la Mariposa: "Cuando llego al parque, sé que allí está mi amiga Julia...que está mi pareja...que están personas con quien yo me relaciono y me siento muy bien...(When I reach the park, I know that my friend Julia is there...that my girlfriend is there...that there are the people I relate to and with whom I feel good)" (La Costeña, Exploratory Interview, February 11, 2010). With the impending changes to the park, the atmosphere will no longer draw out these feelings. The following auto-photographed images taken by four different research actors show la Mariposa and surrounding wholesale stores in their current state.

Photograph 5.18: La Mariposa Before Urban Renewal

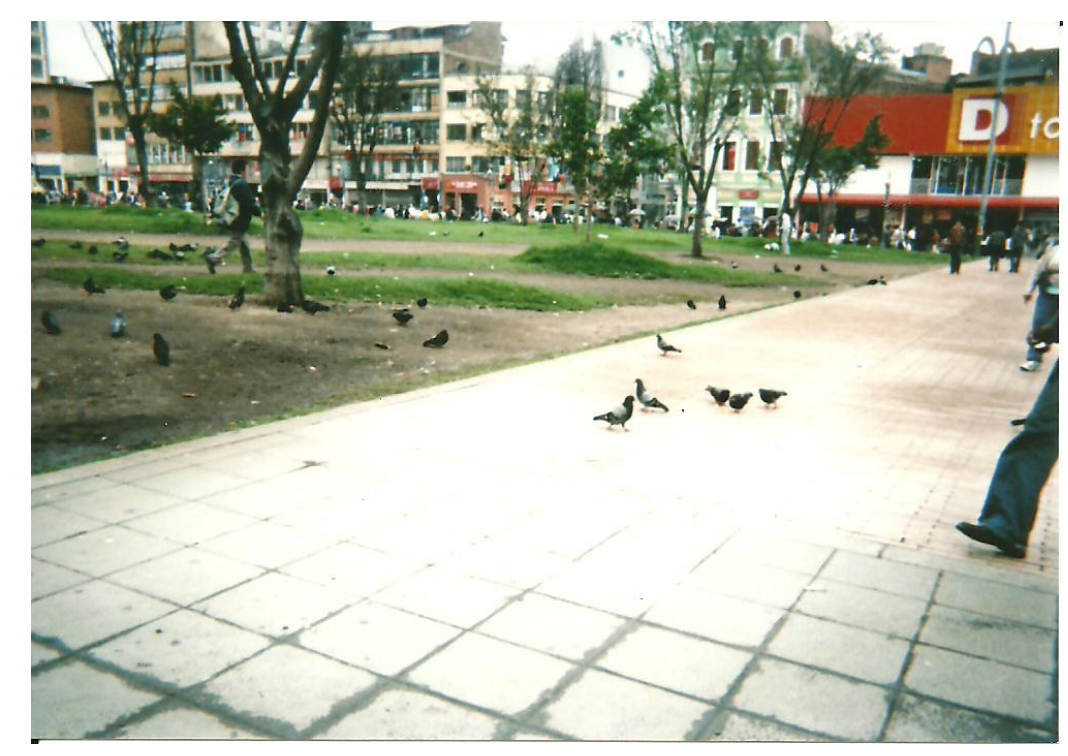


Photograph 5.19: La Mariposa Before Urban Renewal

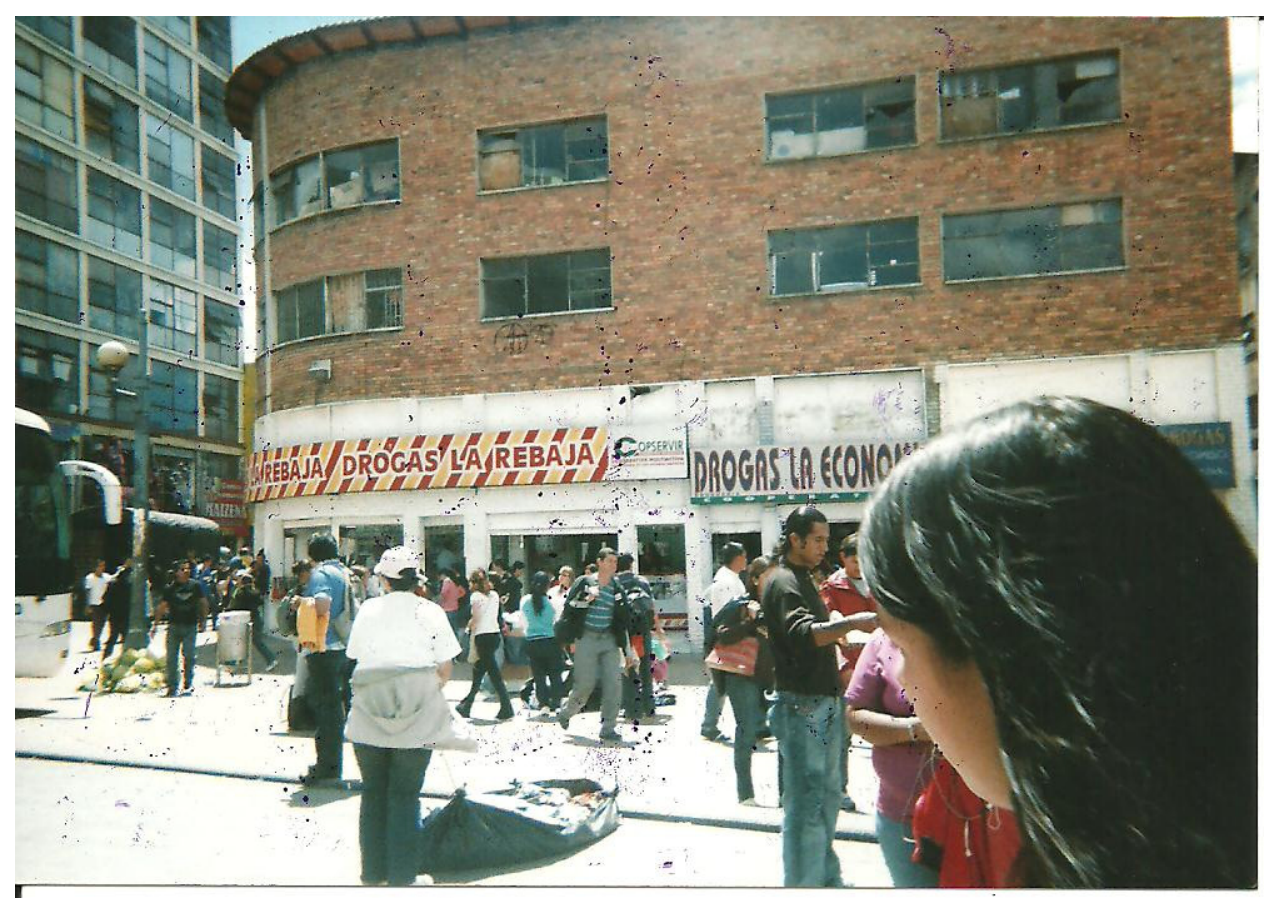

Photograph 5.20: La Mariposa Before Urban Renewal

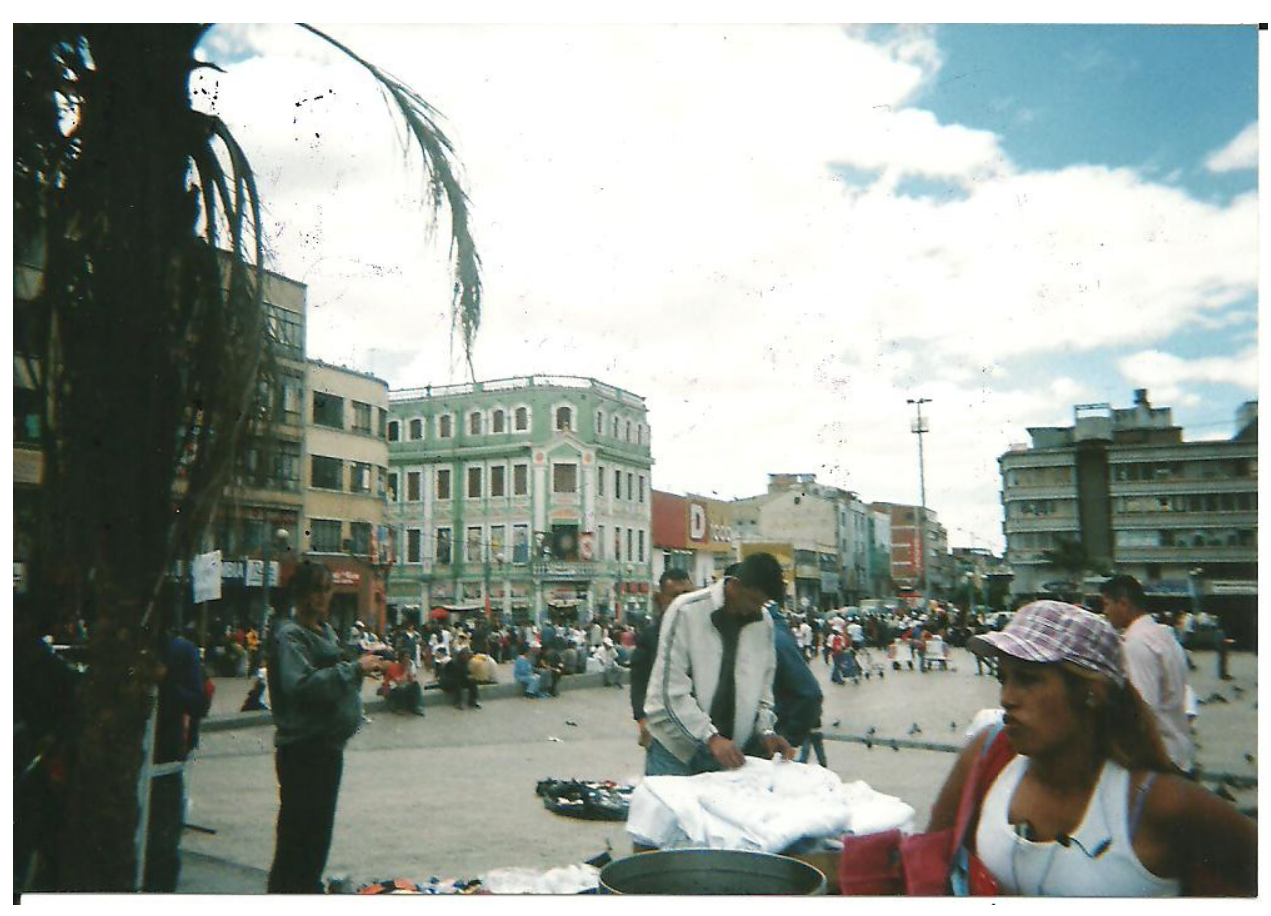




\section{Photograph 5.21: La Mariposa Before Urban Renewal}

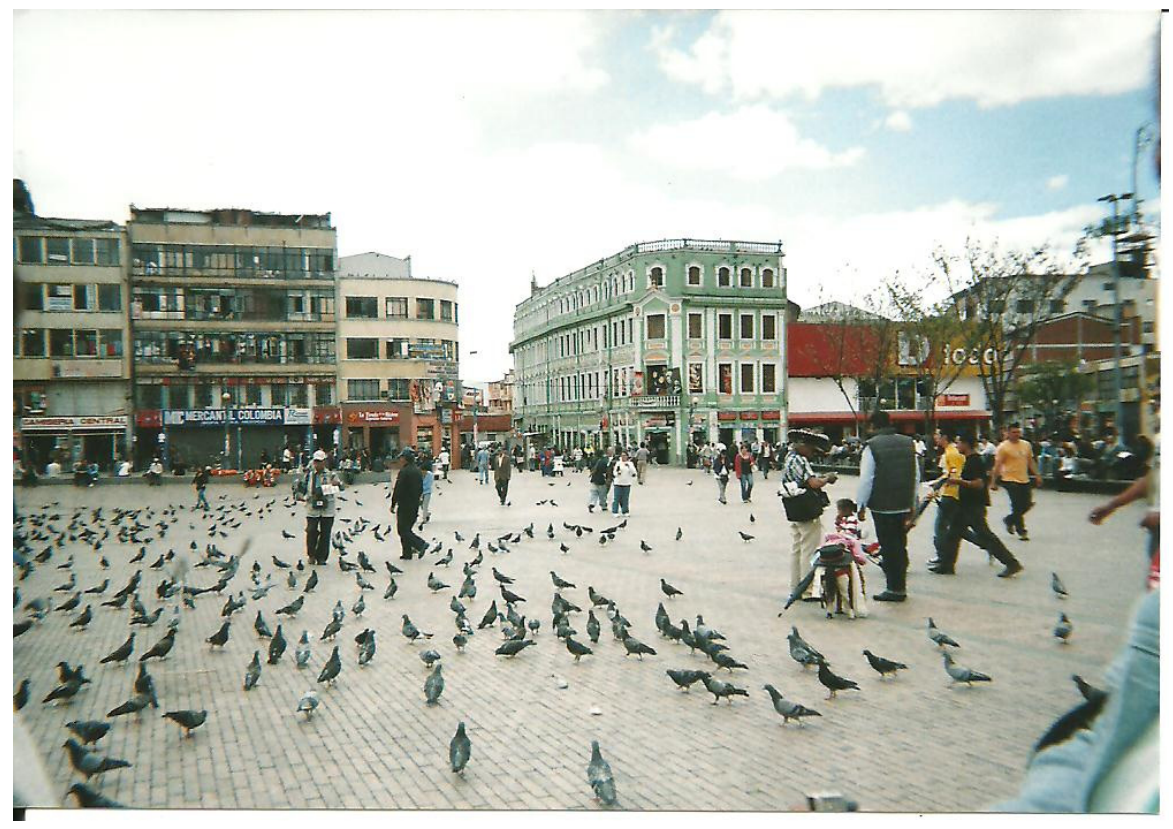

After completion of the commercial center rendered below, street girls will find their

Mariposa dominated by a newly paved, high-surveillance commercial center with

surroundings not friendly to or permitting the presence of street girls or any of the current actors in the San Victorino scene.

Figure 5.4: Project Planning Image - la Mariposa

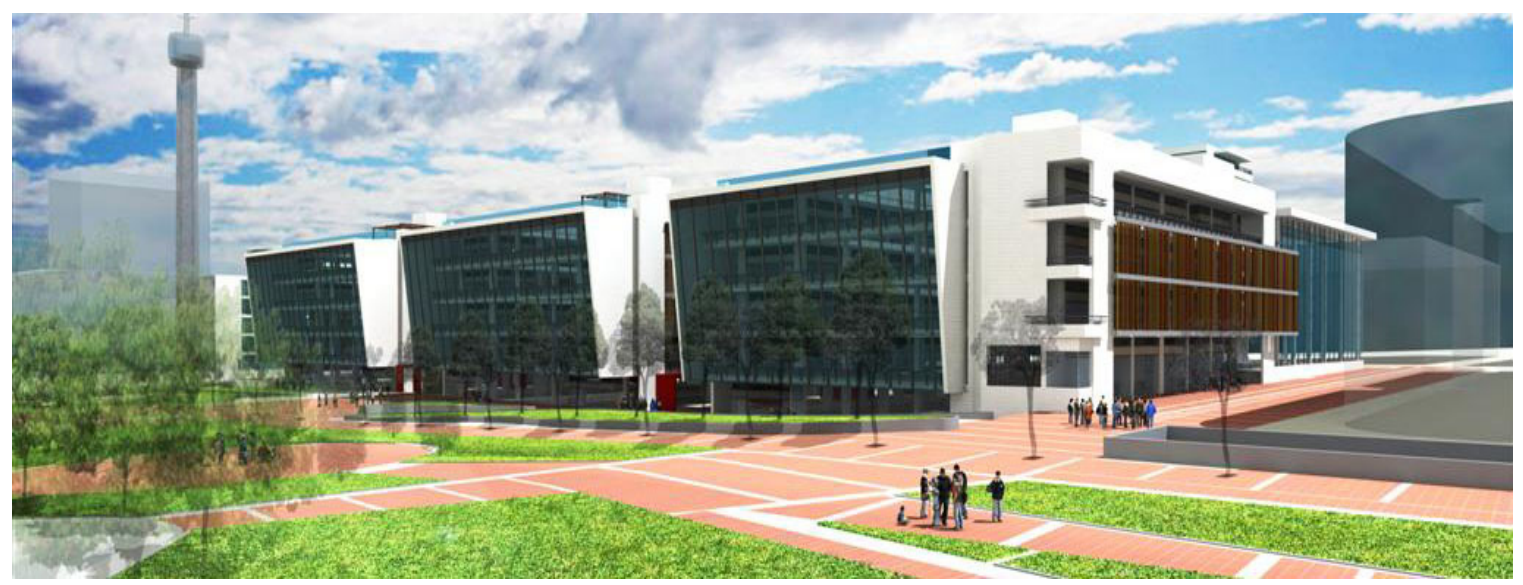


When construction starts in 2011, the 'San Victorino Centro Internacional de Comercio Mayorista' will transform the physical, emotional, and social environment of these girls' main activity space, la Mariposa.

The project website says this commercial center will be connected by broad pedestrian walk-ways starting in the old colonial city center (la Candelaria), leading to the buildings' $10^{\text {th }}$ Avenue entrance and also connecting to El Parque Tercer Milenio (http://www.eru.gov.co/index.php?id_c=8\&tpl=articulo, accessed February 1, 2011). The construction targets the north zone of El Parque Tercer Milenio between $11^{\text {th }}$ Avenue and Caracas Avenue and $10^{\text {th }}$ and $11^{\text {th }}$ Streets. The project website also emphasizes that a main purpose of the construction is that it will: "complementará las obras del Parque Tercer Milenio y repotenciará el carácter comerical y popular del sector San Victorino (complement the El Parque Tercer Milenio project and will revitalize the commercial and popular character of the San Victorino area)" (http://www.eru.gov.co/index.php?id c=8\&tpl=articulo, accessed February 1, 2011). The "diseño moderno del centro comercial busca convertirlo en un nuevo atractivo turístico y comercial para propios y extraños (modern design of the commercial center is intended to turn it into a new tourist and commercial attraction for locals and foreigners)" (http://www.eru.gov.co/index.php?id_c=8\&tpl=articulo, accessed February 1, 2011). The website also promises the center will offer new recreational spaces: “Amplios espacios y áreas verdes se podrán disfrutar en el Centro Comercial, cuyas obras comenzarán a finales de este año (Open spaces and green areas can be enjoyed in the Commerical Center, whose construction will start at the end of this year)" (http://www.eru.gov.co/index.php?id_c=8\&tpl=articulo, accessed February 1, 2011). 
When asked her opinion of the projected changes for the Mariposa and shown the

planning image, El Cilencio notes:

En el sector de San Victorino, igual que en el Tercer Milenio, no están teniendo en cuenta las miles de personas que de una u otra forma subsisten con este trabajo de venta mayoritaria porque al poner un centro comercial internacional las posibilidades de obtener un local alli sería casi imposible porque como su misma frase lo dice internacional sería para personas estudiadas que sepan varios idiomas... La seguridad sería demasiada ... ya no sería una plazoleta para cualquier persona sino para personas de plata...todos los vendedores ambulantes, chazeros, las trabajadoras sexuales, y hasta los mismos ladrones se verían en una situación crítica... la exclusión de la gente de bajos recursos aumentaría más de lo que está ahora... los habitantes de calle, como el estado le llama, tendrían un solo camino... la muerte...San Victorino...un centro comercial internacional a cambio de muerte, pobreza, indigencia...una presentable arquitectura desvalorizando y tapando el sufrimiento de personas que con su esfuerzo han logrado un puesto en esta zona...una montón de ladrillos enterrando la esperanza de todas estas personas...(In the San Victorino area, just as in the [El Parque] Tercer Milenio, they are not taking into account the thousands of people who one way or another earn their living in the wholesale business because when they put in a commercial center the chances of getting a store there will be almost impossible because in their own phrasing they call it international, so it will be for educated people who know various languages... security will be too heavy...it won't be a square for use by just anybody but for people with Money....all the street sellers, peddlers, the sex workers, even the thieves themselves, will find themselves in a critical situation...the exclusion of people with few resources will become worse than it is now...the street dwellers, as the state calls them, will only have one avenue...towards death...San Victorino... an international commercial center in exchange for death, poverty, homelessness... impressive architecture, devaluing and covering up the suffering of people who had made the effort to gain a place in this zone... a pile of bricks burying the hope of all these people ) (El Cilencio, Participatory Writing Workshop, January 2011).

Trans (Im)mobility: My life in Three Blocks and a Cemetery

Santa Fé, while known to outsiders and officially referred to as la zona de tolerancia, is known amongst street communities as the zona trans (the transgender 
zone). Within the trans-community this has been demonstrated through activist efforts such as the campaign to re-claim public space illustrated in the following event flyer.

Figure 5.5: Re-appropriating Urban Space

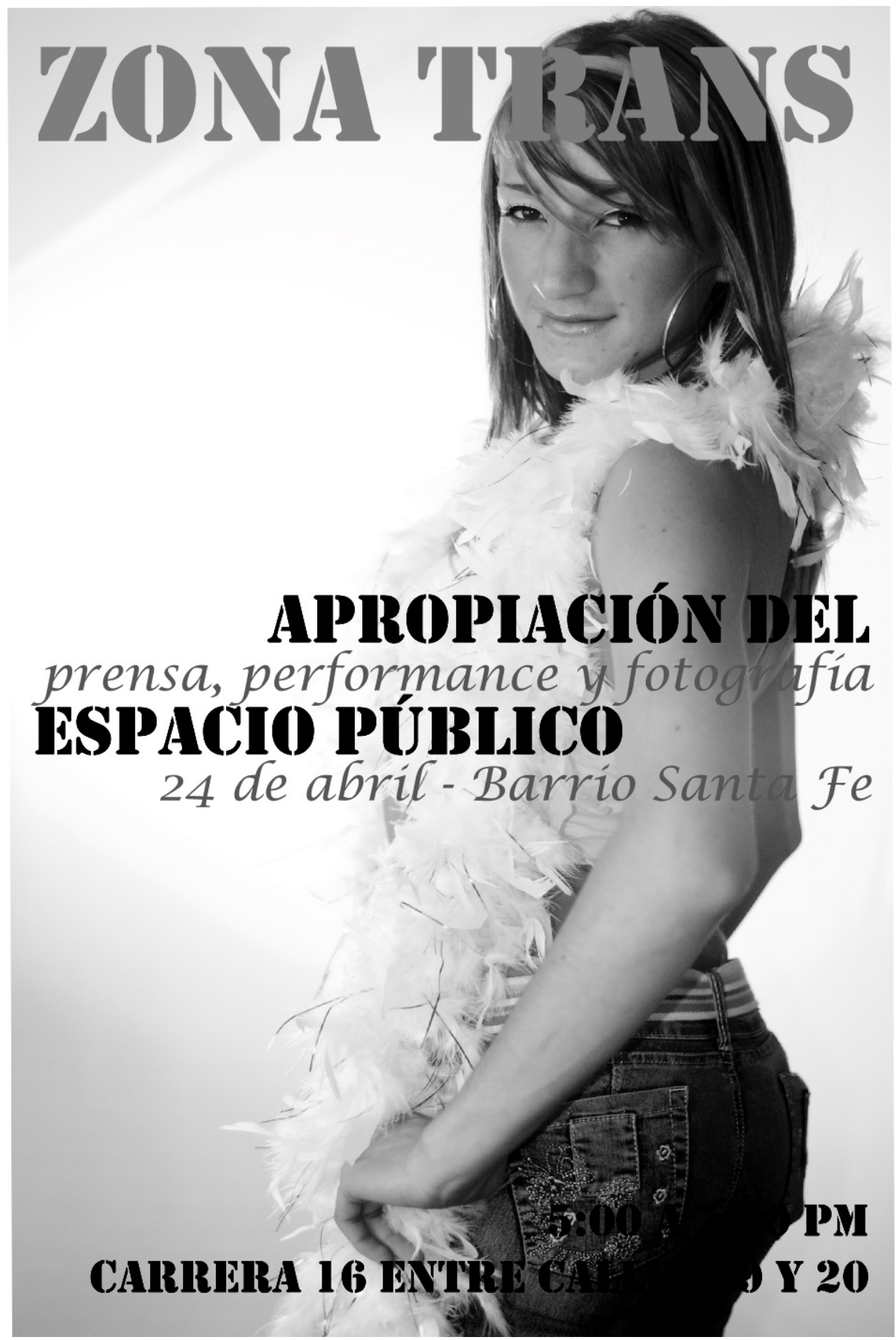


Tara, featured in the zona trans flyer, was one of my first contacts within the trans-community. She introduced me to other principal research actors in Santa Fé during activist events and community leadership activities in the study site.

In contrast to illustrations of spatial exclusion through urban renewal efforts discussed in previous sections, this section illustrates trans-girls' geographies of exclusion through the visualization of their limited mobilities within the city in general and within the study site (Santa Fé) in particular. These limited mobilities are linked to perceptions of danger both within and outside of the barrio, indicating that trans-girls' geographies of belonging are complexly intertwined and overlap with geographies of exclusion, rejection, mistrust and violence. While 8 out of 10 trans- research actors represent Santa Fé as a dangerous space often referring to current waves of social cleansing in the zone, their main activity, home, safe and central spaces appear within the same area on the map. As shown in Map 5.9 illustrating the urban journeys of the Transgender subgroup, when trans-research actors leave the three-block sector of the zona trans in Santa Fé their trajectories demonstrate movement to and from Chapinero on the big business nights in the LGBT entertainment district in Bogotá, frequented by clients across social strata. 


\section{Map 5.13: Santa Fé Activity Spaces - Transgender Subgroup}

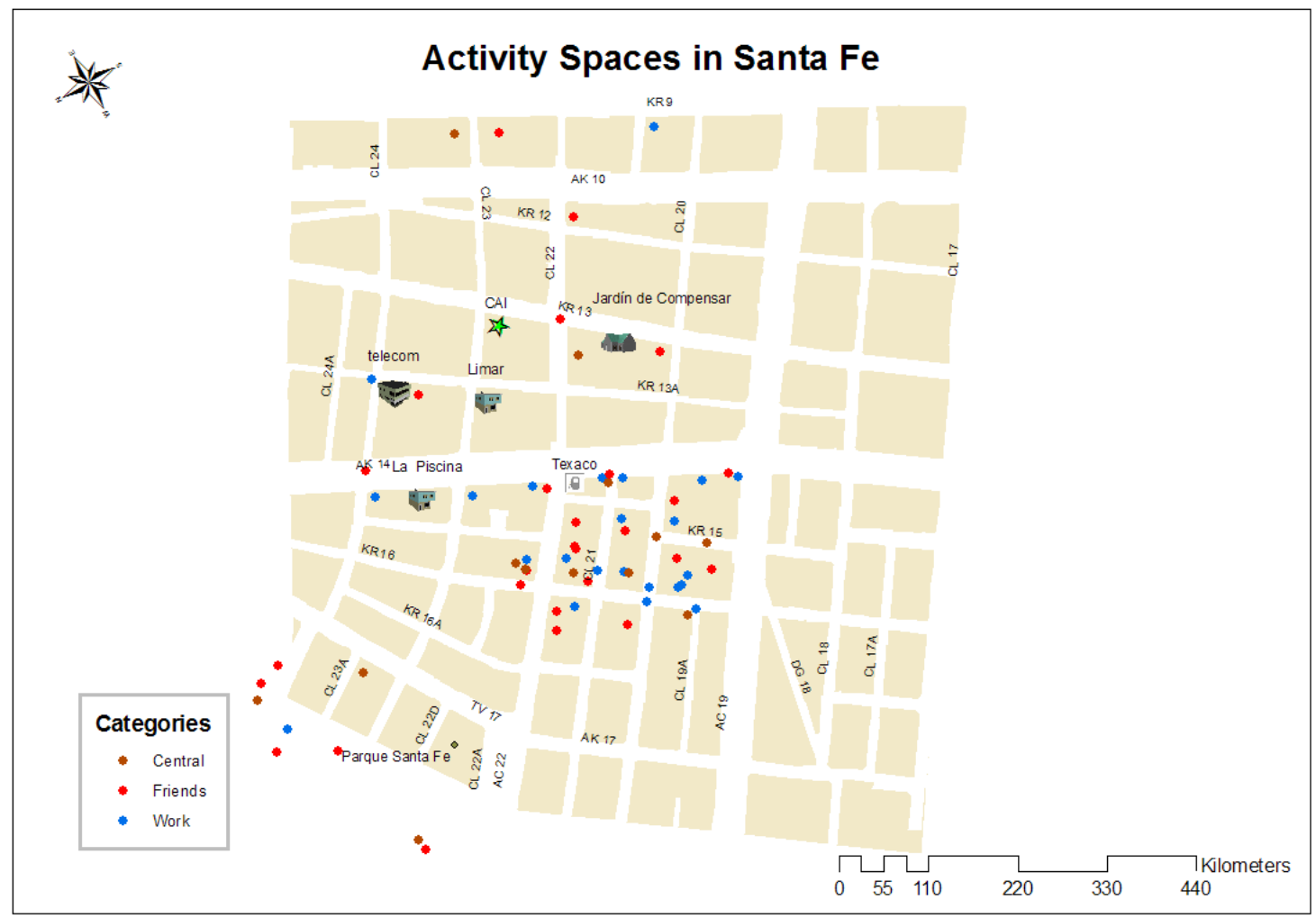

Map 5.13 visualizes trans-girls' 'central', 'work' and 'friend' activity spaces in

Santa Fé. During a data analysis workshop, two principal research actors of the

Transgender Subgroup identified these three spatial variables as the most relevant to trans-girls' everyday activity spaces. A participatory analysis and data presentation approach was used to guide the construction of each study site map. Ten out of 10 research actors marked 'friend,' 'central,' and 'work,'categories at least once on the map. Trans-girl activity spaces are concentrated within three-blocks of the barrio in the transwork zone located between $19^{\text {th }}$ and $22^{\text {nd }}$ Street and Caracas and $16^{\text {th }}$ Avenue.

To illustrate 'friend' spaces on the map, Daya, for example, selected a red candado (padlock) symbol and explained: 
“...lo que siempre [digo]...como un espacio cerrado alli en ese mismo pedazo...socializamos en el mismo pedazo... por lo que te decía ahorita ...no tengo mas a donde ir ...son los mismos amigos...porque si uno tuviera un amigo... hay sí lejos ... yo me fuera...que me dijera ... 'vente una semana pa' mi finca'...yo, claro! Ahhh [grita]... (... what I always [say]...like a closed space there [always] in the same place...we socialize in the same place...like I just told you...I don't have anywhere else to go...[it's always] the same friends...because if you had a friend...oh yes far [away]...I would go...that he would say... 'come to my farm [meaning country house] for a week'...I, [would say] of course! Ahhh [screams]) (Daya, Mapping Interview, July 7, 2010).

\section{Map 5.14: Trans-Life 'Locked' in Three Blocks}

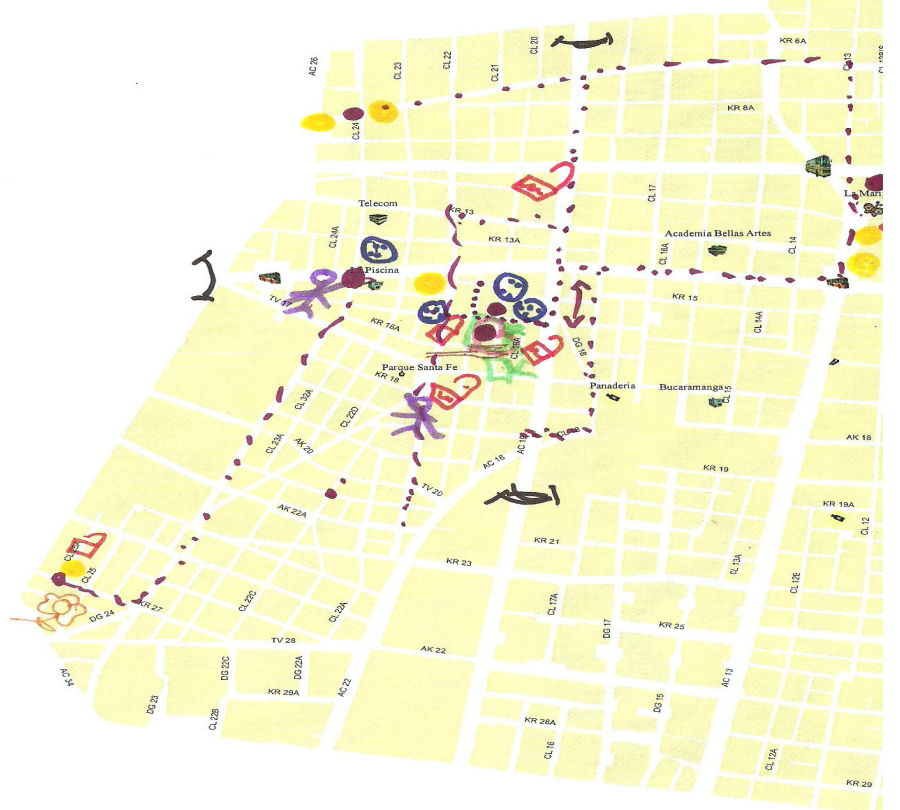


In this explanation, Daya expresses frustration with her constrained mobility and seems to be fed-up with the same scene and same friends day after day in the zona trans of Santa Fé. As visualized in her cognitive map, Daya enclosed all of her activity points in Santa Fé with red padlock symbols.

Photograph 5.22: Brothel as 'Home'

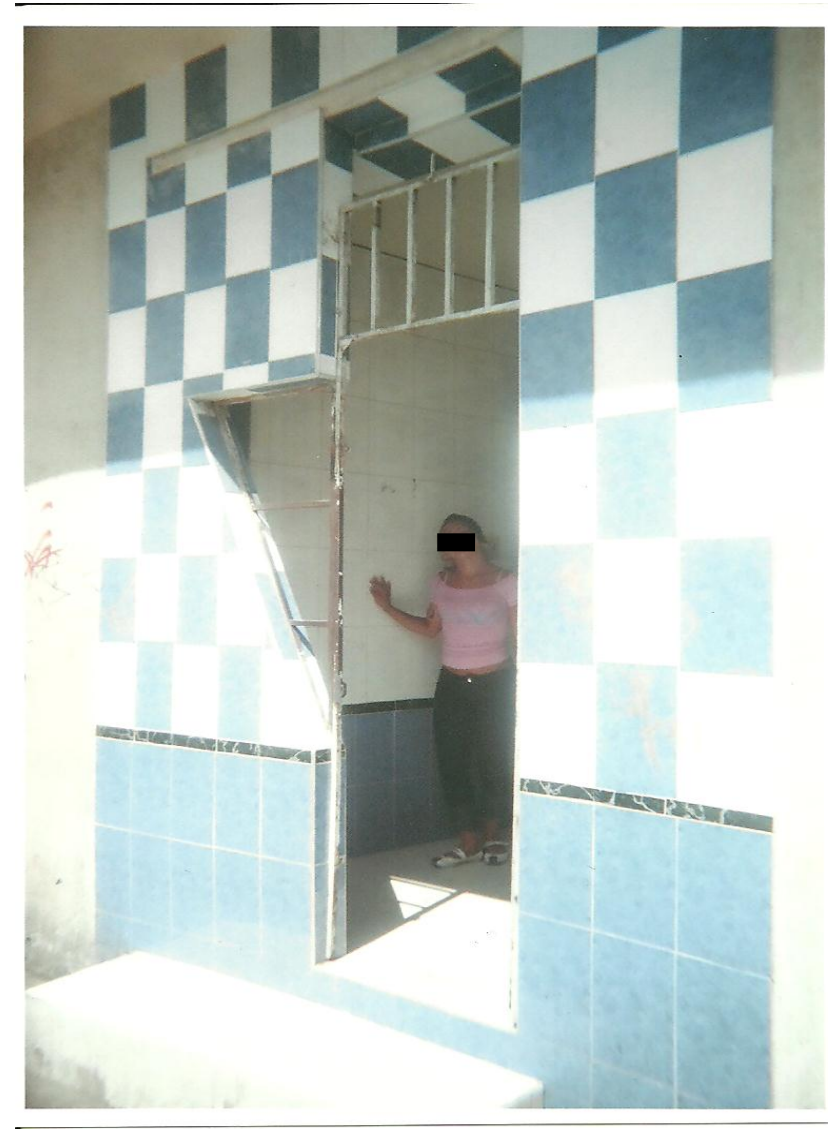

Three other trans-girls sketched padlocks on their Santa Fé maps; however, instead of representing the feeling of being locked-in to the same 'friend' spaces and spatial routine, the padlock represents feelings of safety and the location of safe spaces in Santa Fé. Tina described the importance of the padlock for her safety: “...porque hay seguridad en la puerta...primer y segundo piso... (because the door is locked...on the first and second floor [entrances to her building])" (Tina, Mapping Interview, May 13, 
2010). Without this protection, she added, her home would not be a safe space for her or others living in the building.

\section{Photograph 5.23: Only Safe Behind Locked Doors}

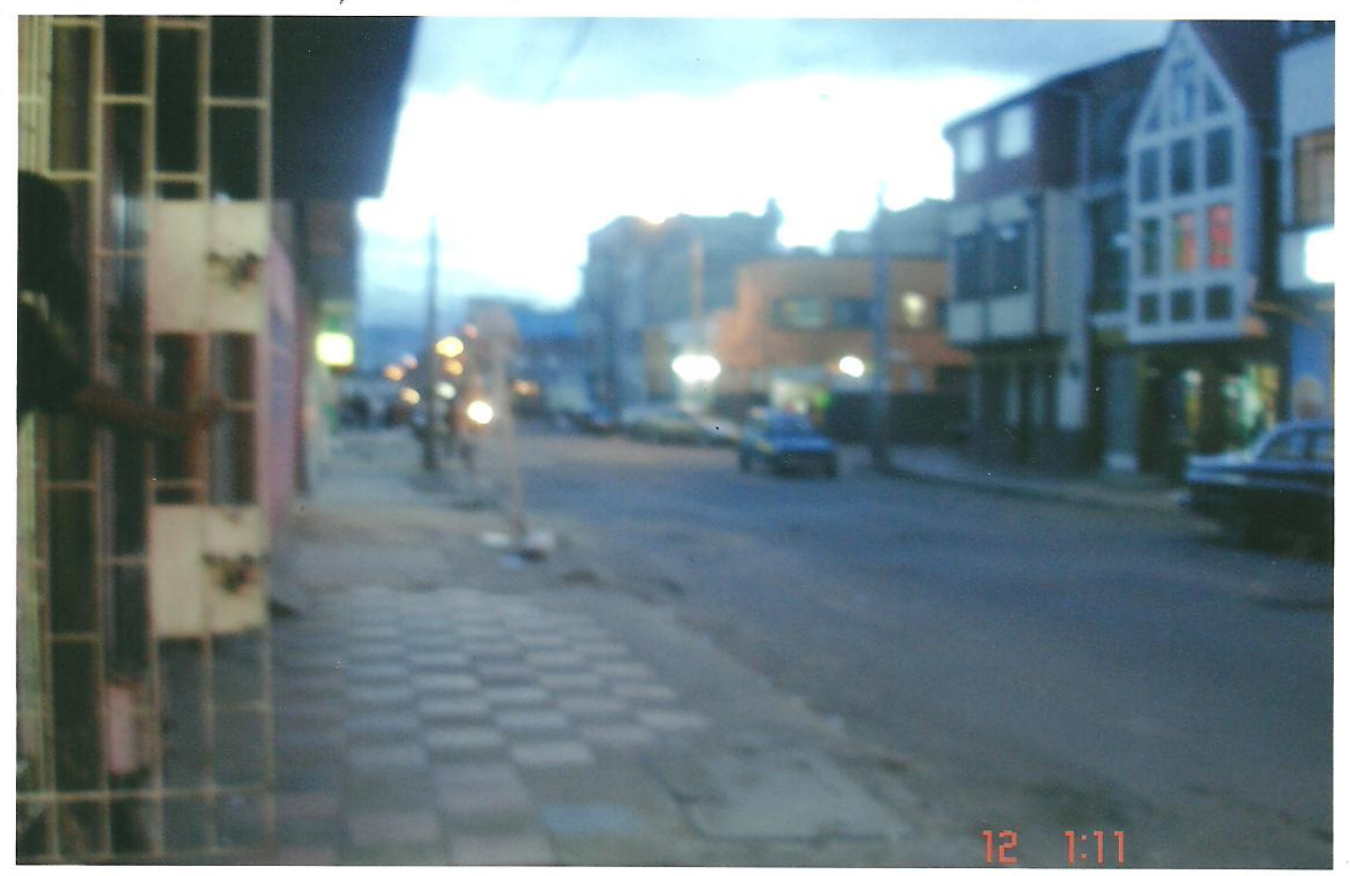

Although Tina is both a sex worker and hairdresser, she chose to represent all 'work' spaces with blue scissor symbols, including corners where she waits for clients and the hair salon where she works. Similarly, her friend from work (both in the street and the salon) marked both sex and salon 'work' spaces with blue hairdryer symbols. 


\section{Map 5.15: Spatial Representations of 'Work'}

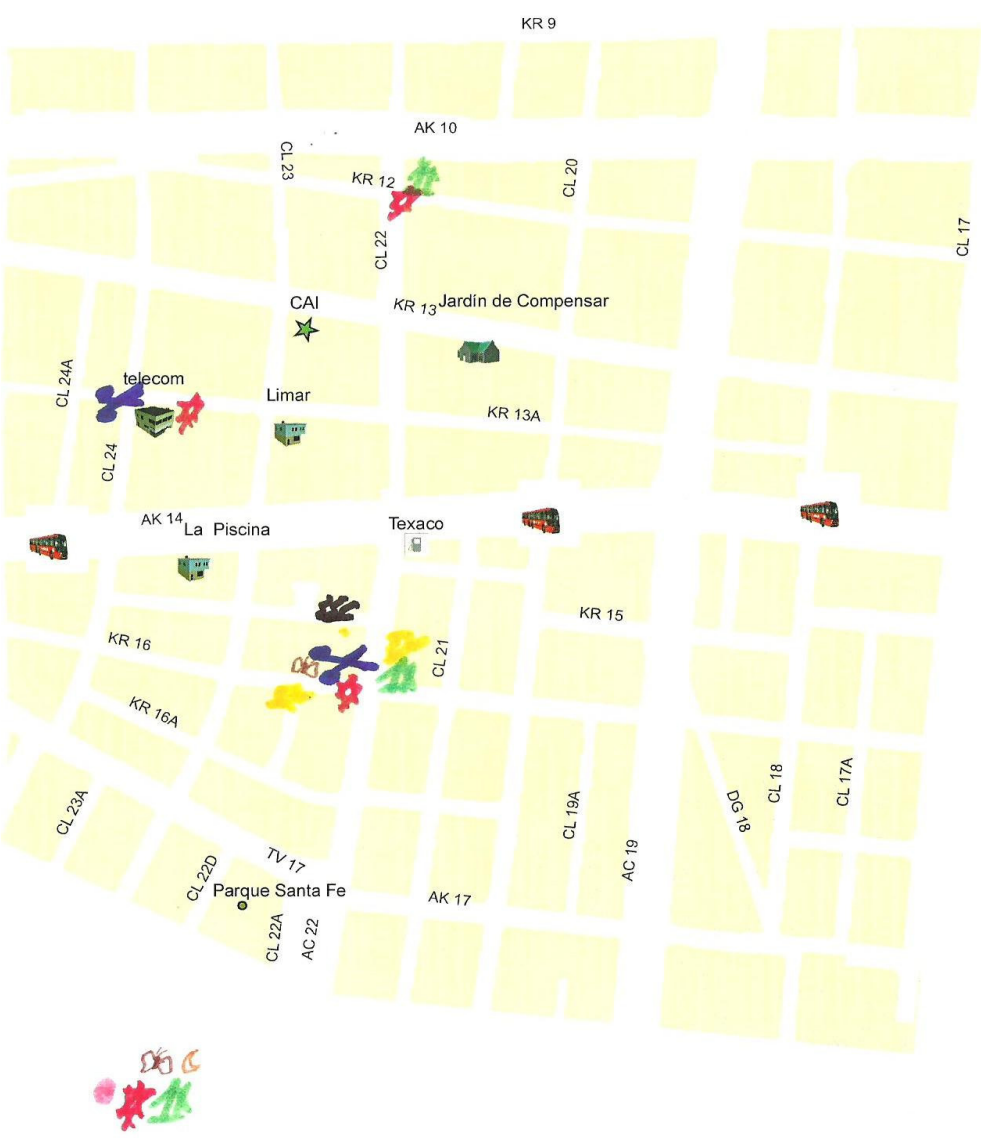

Representing her mobility within Santa Fé, Tina marks her central spaces with a brown butterfly symbol because: “...uno se mantiene de lado a lado (because one [constantly] moves from place to place)" (Tina, Mapping Interview, May 13, 2010). During the mapping interview, Tina marked two central places including the peluquería where she works and the building where she lives, both in Santa Fé. 


\section{Photograph 5.24: More than Sex Work}

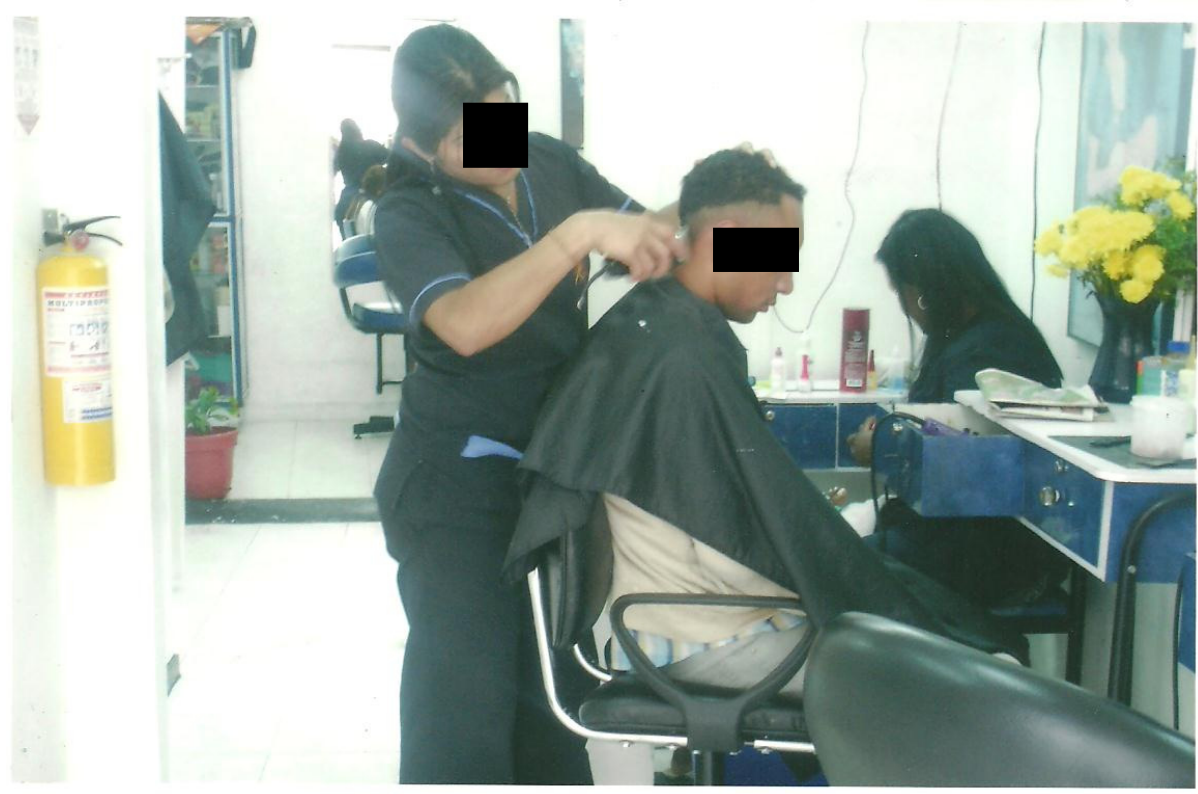

While trans-girls' activity spaces are concentrated in Santa Fé, five girls did mark spaces outside of Santa Fé. The majority of these spaces, however, are marked by perception symbols (i.e., yellow symbols identifying public spaces [such as the National Park], black symbols identifying other dangerous spaces in the city [such as la 'L'], purple symbols identifying spaces of exclusion [especially in the north of city], etc.) and therefore do not represent trans-girl activity spaces. 


\section{Map 5.16: Perceptions of Safety and Danger in Santa Fé}

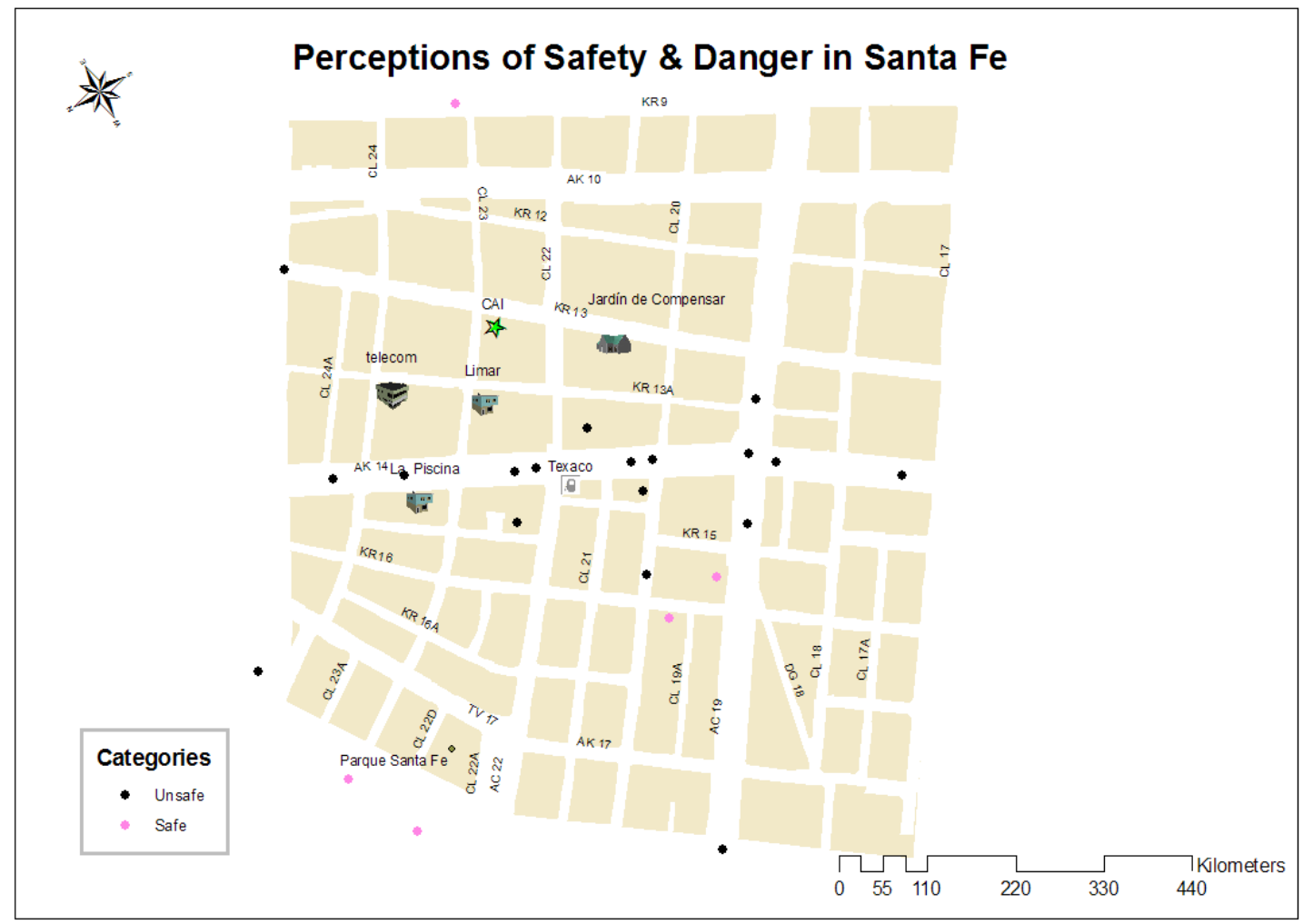

Map 5.16 visualizes trans-girls' perceptions of safe and unsafe spaces in Santa Fé.

Eight out of ten research actors marked at least one dangerous space in Santa Fé.

For Maricela, there are no safe places in Santa Fé. Although she works along $16^{\text {th }}$ Avenue and in a brothel on $22^{\text {nd }}$ street (marked with blue butterfly symbols), socializes with friends by La Piscina brothel and near El Parque Santa Fé (marked with red suns), eats chicken at a (public) cafeteria on $22^{\text {nd }}$ street (marked with a yellow sun) and spends time in her (private) and (central) pay-per-day hotel room close to the Central Cemetery (marked with a green flower and brown smiley face, respectively), Maricela sees all of Santa Fé as a dangerous space (marked with a large, black flame or fire symbol covering all of her activity spaces). During her mapping interview, she repeatedly emphasized not trusting anyone in the zone besides her two roommates and walking around half- 
expecting to be mugged. She also observed that Santa Fé had become increasingly unsafe for trans-girls over the last six months and that even 'they' (trans-girls, often stigmatized in the zone as muggers) are getting mugged (Maricela, Mapping Interview, July 10, 2010).

Map 5.17: Perceptions of Danger in the 'Zona Trans'

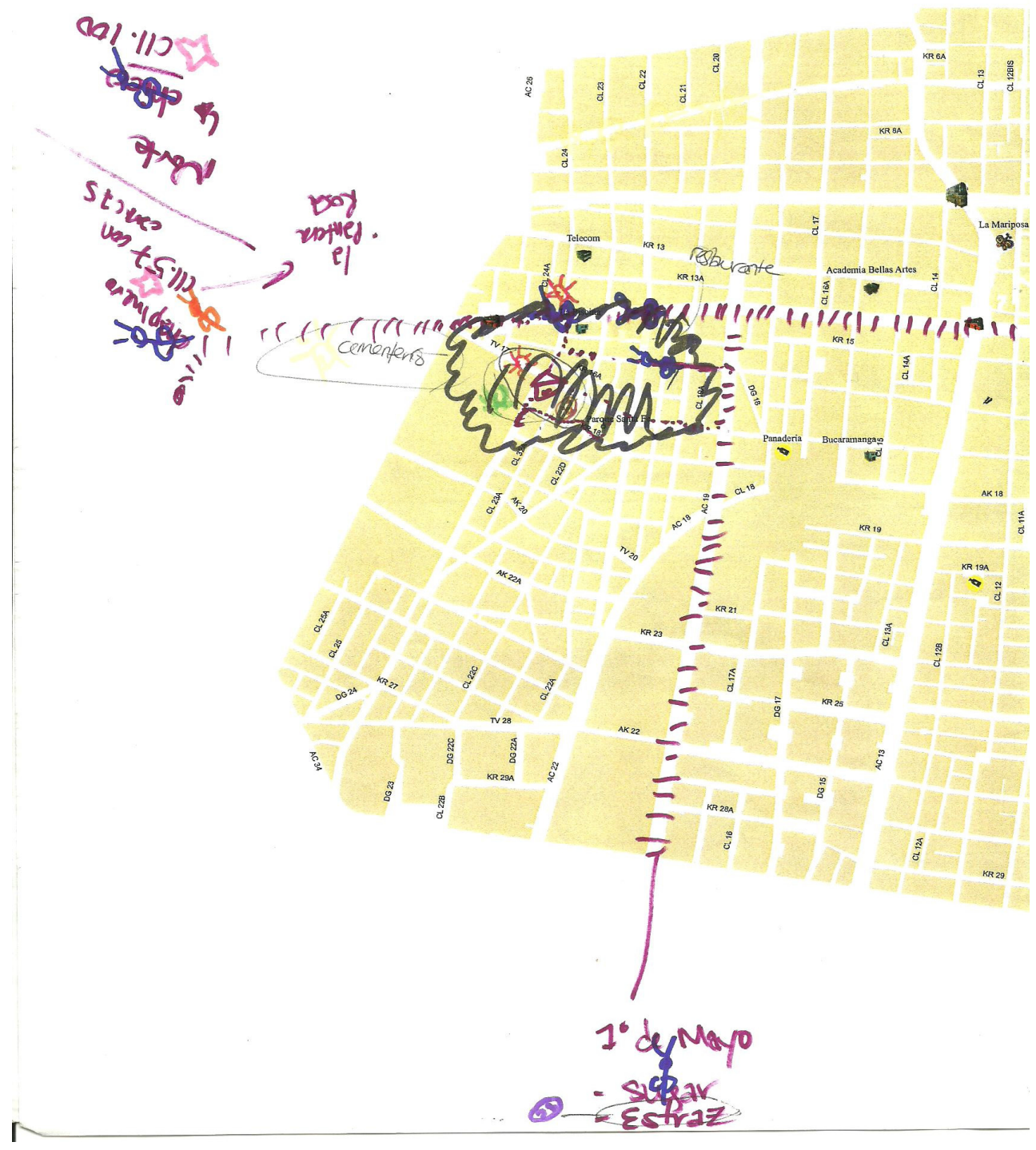


Mafe expressed a similar perception of danger in the barrio when describing her symbol for unsafe spaces as: “...una avenida ...la Caracas...la calle donde trabajamos...todo es peligroso...(an avenue...the Caracas...the street where we work...everything [on this street] is dangerous)" (Mafe, Mapping Interview, July 13, 2010). One other research actor used a street symbol next to a knife to represent danger. She explained that she and many of her peers have been stabbed in the streets and for this reason associates the streets with danger.

\section{Map 5.18: Images of the Street as Danger}

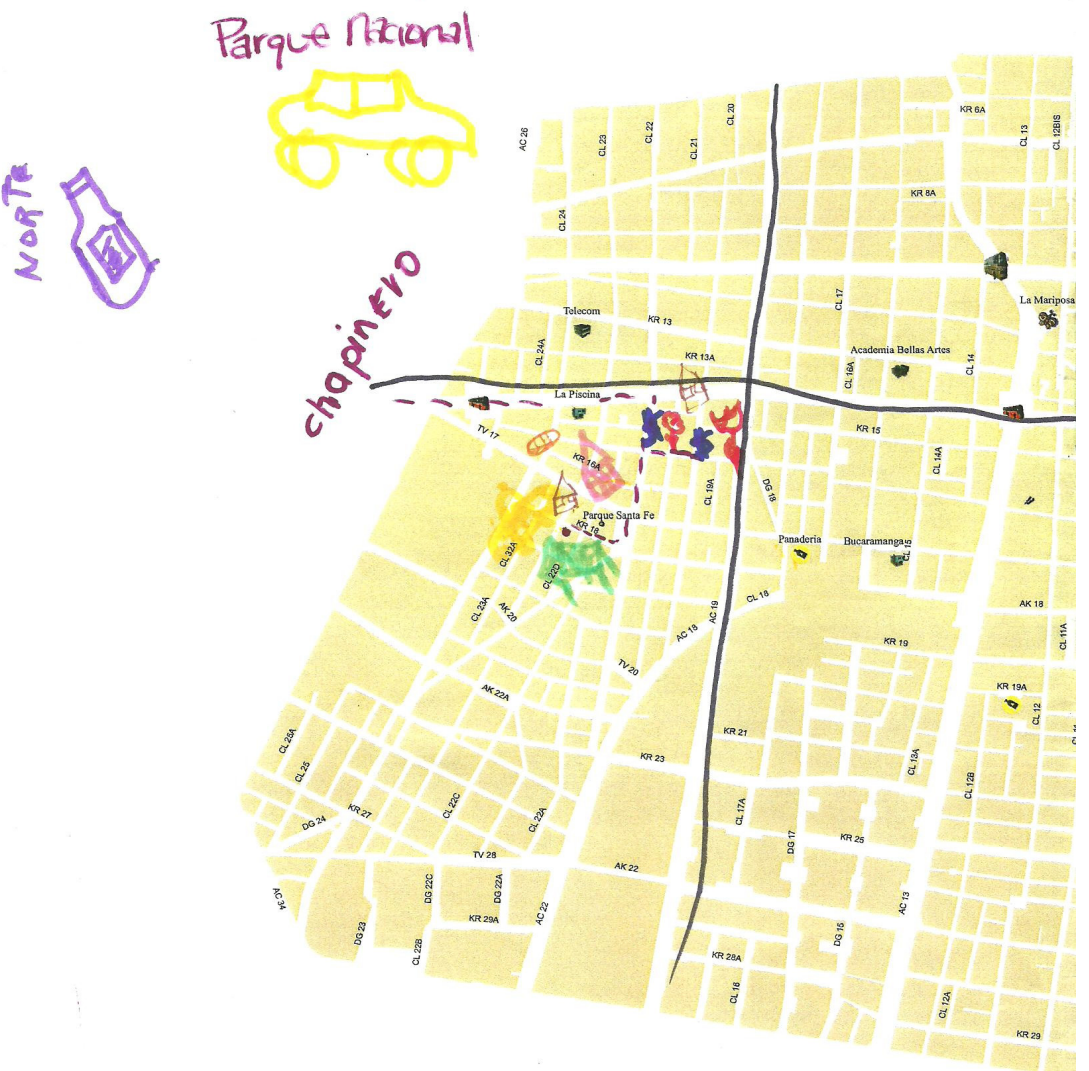

Four research actors used symbols for fire, flame or burning objects to represent unsafe spaces. Unsafe and danger were terms often interchanged by research actors 
during interviews when discussing this spatial variable. As Brella explained when describing her flame symbol for danger: “...si se acerca, se quema...(...if you get close, you burn...)" (Brella, Mapping Interview, July 6, 2010). Fran provides a similar explanation for the choice of her sun symbol for danger. She describes the symbol as a sun: “...que quema...que arde...que uno suda...que pica...(that burns...that stings...that [makes] you sweat...that itches...)" (Fran, Mapping Interview, July 22, 2010).

Map 5.19: Danger Burns in Santa Fé

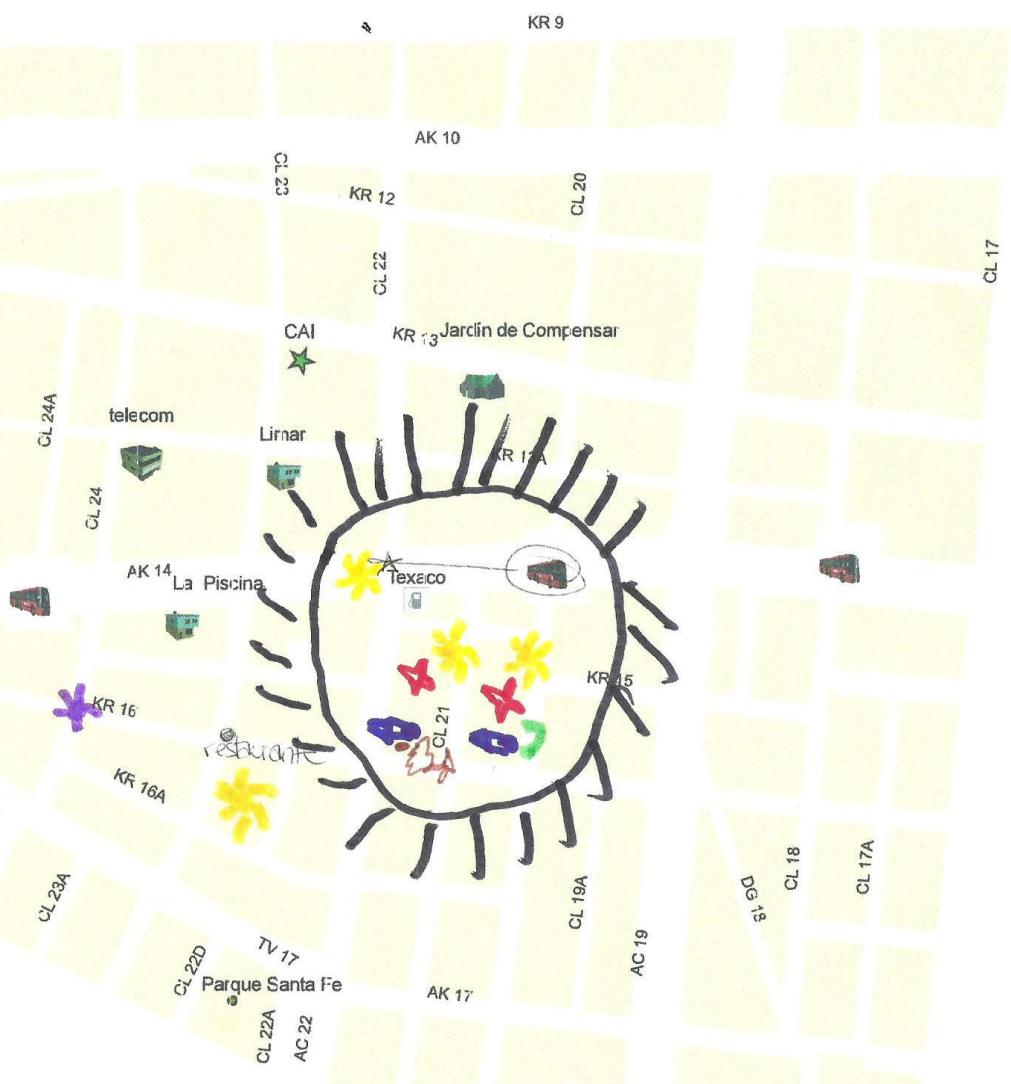


These associations of dangerous spaces with physical discomfort, pain and fear echo

research actors' discussions of danger and fear in Santa Fé surrounding social cleansing

killings and/or the pamphlets appearing under their doors or those of a friend (see Figure

\section{6 below).}

\section{Figure 5.6: Social Cleansing Flyer Received by Multiple Research Actors}

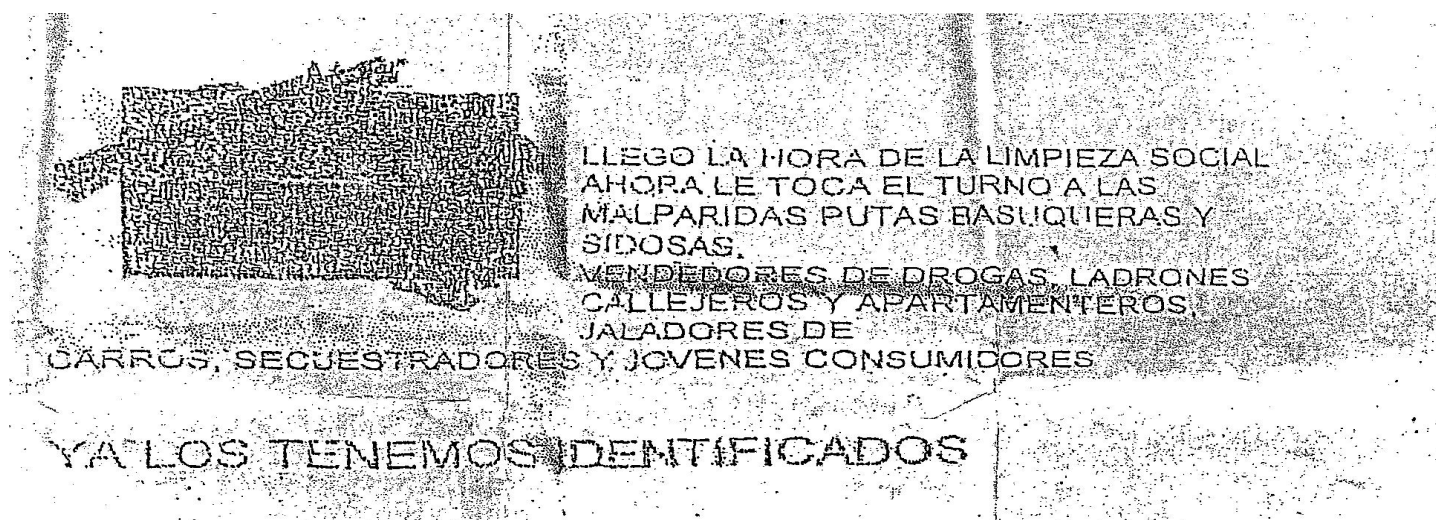

Fara al pucblo an general, tefides han notado una urecionte de la volencia, ratos a atracos. prostitucion $\%$

Consumo de droga, eto endos utumos tiempos, debido a todo esto nuesira organización ha tomadala

Itrevocable decision de ataganta violencia côn VIOLENCGLA.

Ya no van a contagiar de sidja nadie más, solamente a los gusanos.

Thenen las horas contadas, todas las putas de fos bares y canbinas y las malparidas prepano.

franieontagiado abmucha gente des SIDA. Preparense HIJUEPUTAS ..i

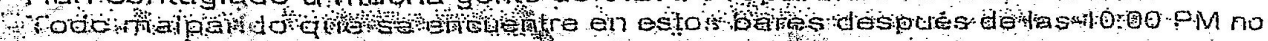

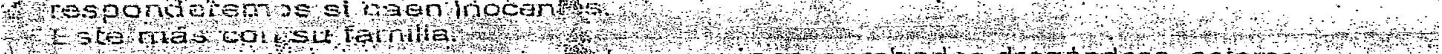

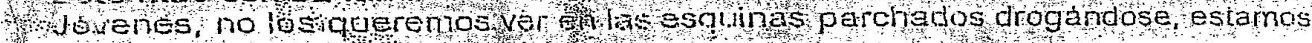

on limpieza esto thomos. Wo

Consuma droga, estudienas y ste con slig padres reciban sus eonsejos y los buerios ejemplos. Éto esta.

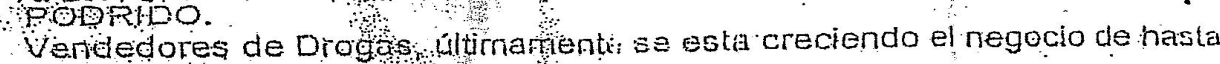
vence droga en las esmuitas, ya no-

mas, métanse esa joga por eltullo ARRIBA, no mas

Lauronzublos, dejentrabajer a k sociedad. Filas que están PILLADOS:

JUIOIO O RAUERTE IJOUED LO

DECIDE ... YATENEMOSUNA LISTA DE BARRIDO INICIAL

La organización lo ha decidiso asj, esta limpleza se necesta.

Empezaremos muy pronto te pedinos perden a la sociedad si caen inocenters

ESTDESSOLO RORUNOS WESEO

MH OW

WELOS LOS QUE CAGA

ENESTA LINPIEZA DDIALOUEO Si vaque vartas coplas y repartalas a tos amigos, vecinos, a a fam famil sujo $4 \mathrm{Li}$

To caigan poíno enterarse solaboracion. 
Two research actors that marked one safe space and no unsafe spaces in Santa Fé also marked the zone as a 'home' space. Bambi sketched a pink padlock next to the Afro-Colombian barbershop where she feels accepted (and can get away from the transSanta Fé scene).

Map 5.20: Perceptions of Home and Exclusion in Santa Fé

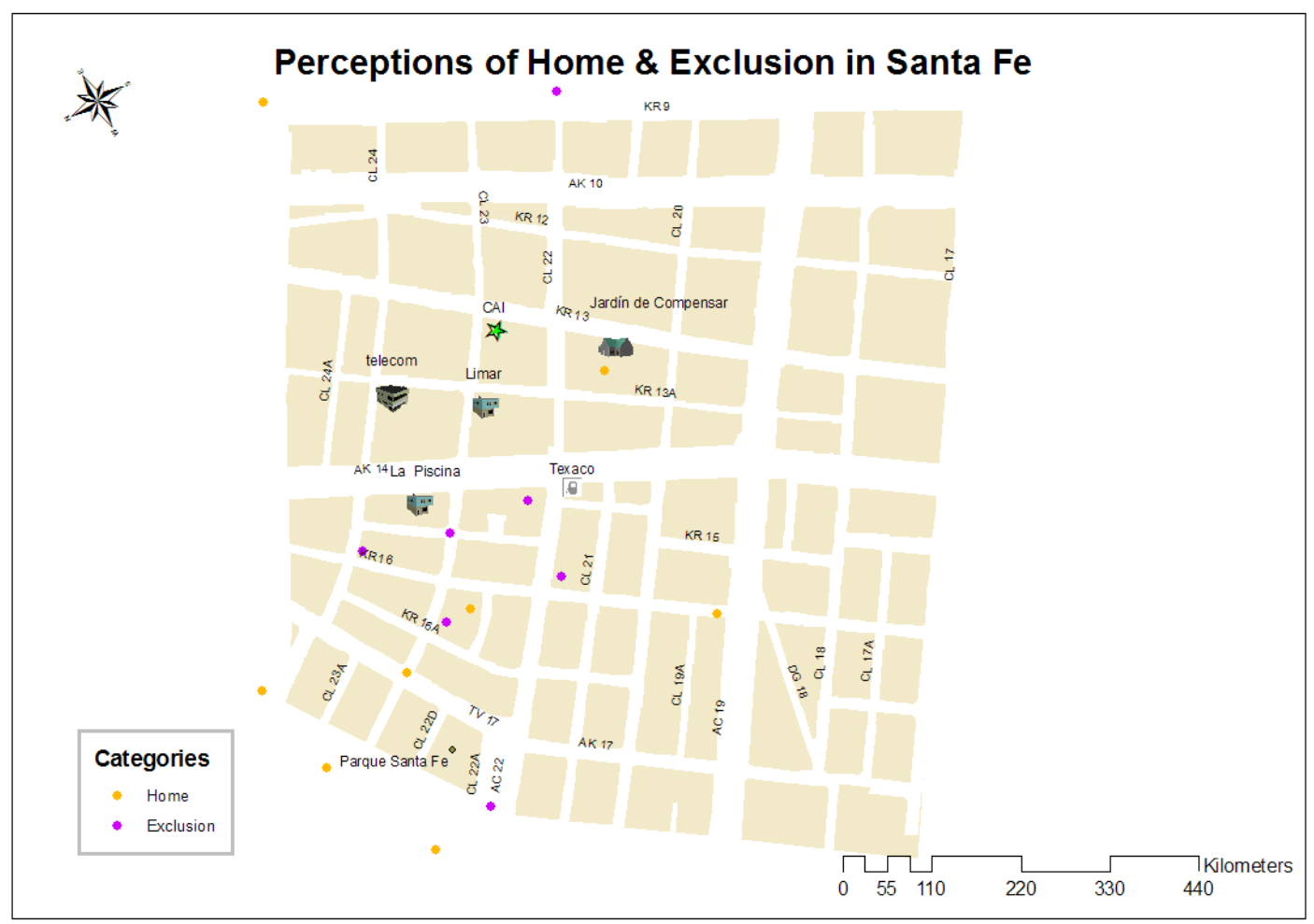

As illustrated in Map 5.20 of Santa Fé, seven out of ten research actors indicate spaces of home in the barrio. All ten research actors in the Transgender Subgroup reported living in Santa Fé during their exploratory interviews; however, as explained in the mapping interviews of three research actors, living in the zone does not necessarily make Santa Fé feel like home.

For Bambi, home is represented by an orange question mark symbol and is located in Santa Fé even though she feels out of place in many spaces there. In the 
mapping interview, she mentioned that "un bar de comportamiento gay... (a gay bar...)" represents her perception of home (Bambi, Mapping Interview, June 26, 2010).

Photograph 5.25: Bambi at 'Home'

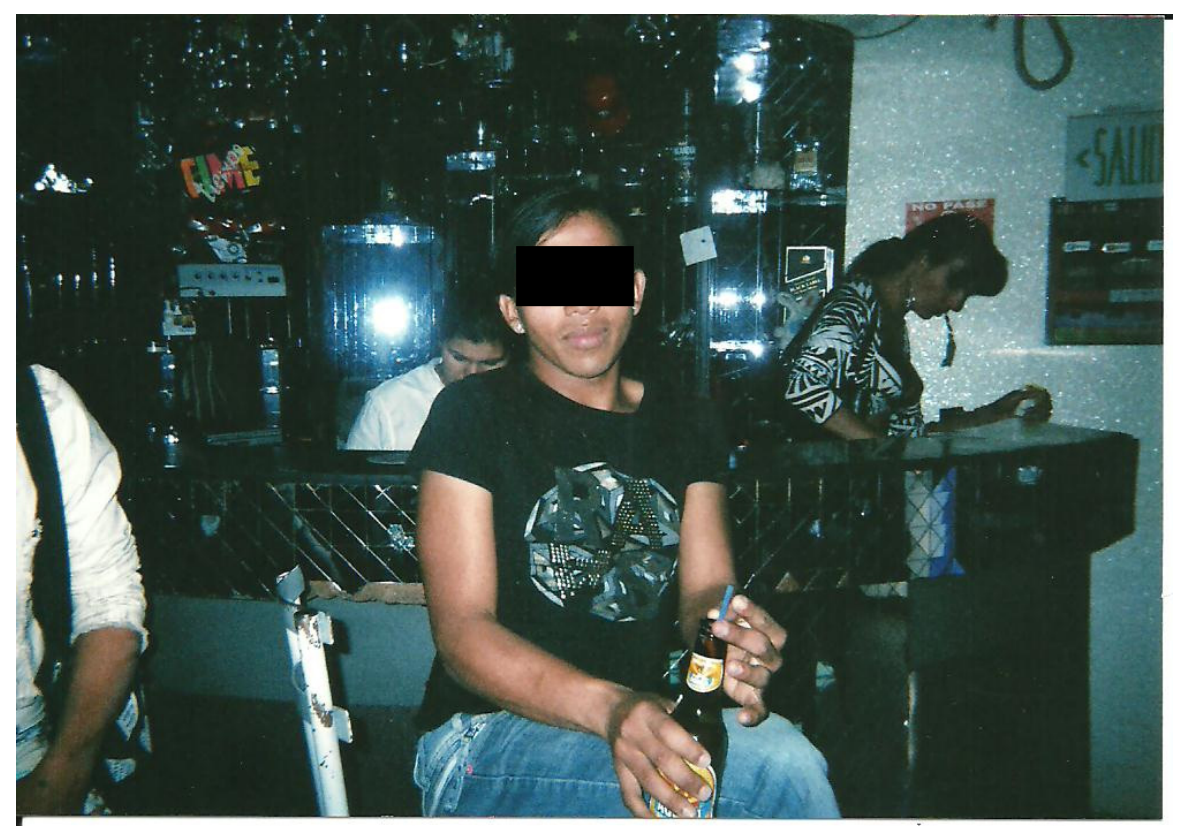

Photograph 5.26: LGBT Bar and 'Home' Space

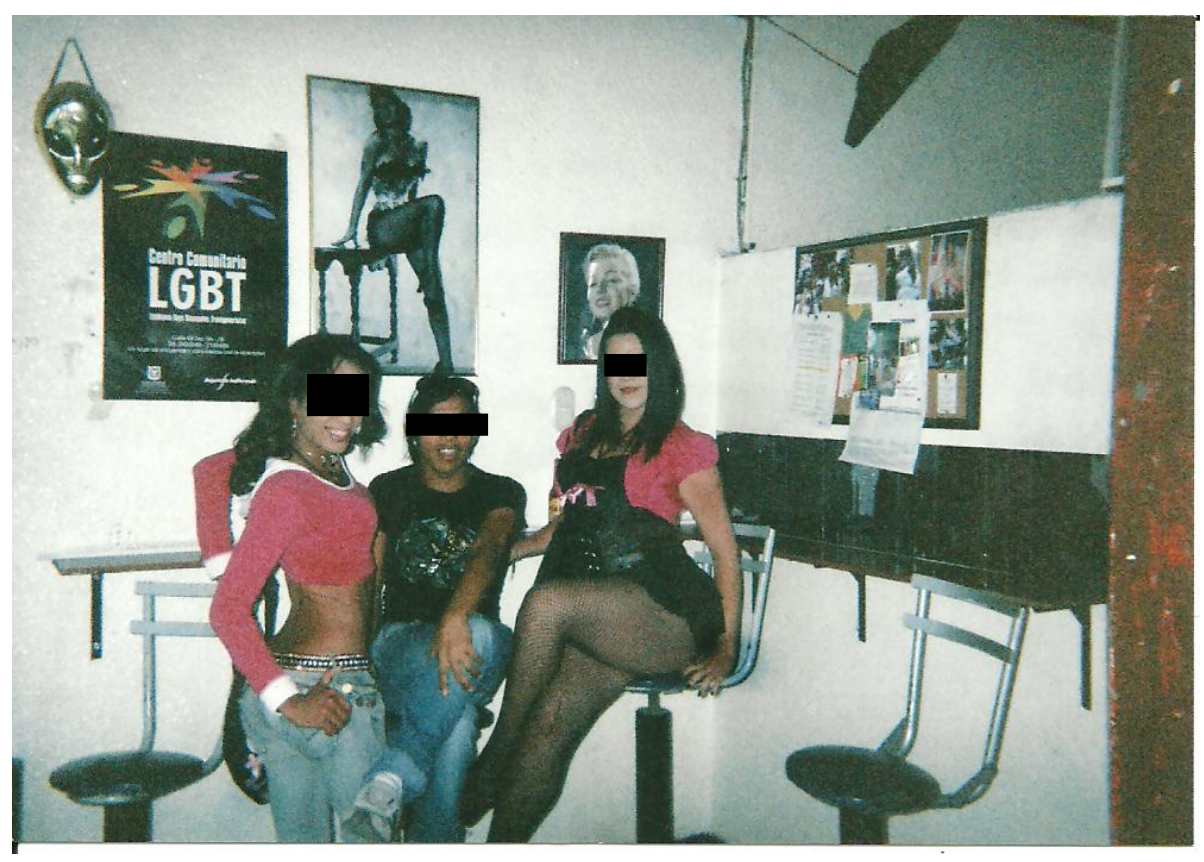


Three out of ten transgender research actors sketched symbols in the Santa Fé map representing the barrio as a space of both home and exclusion. La Ocho's mapping interview reveals perceptions of home surrounding her favorite fast food place. As she draws a food plate with eggs, rice and beans on the corner of $22^{\text {nd }}$ Street with $16^{\text {th }}$ Avenue, she talks about her feelings of comfort “...donde Sofia...(at Sofia's fast food place)" (La Ocho, Mapping Interview, July 10, 2010). La Ocho also mentions feeling at home "donde la Madre (at Big Momma's [brothel])" (La Ocho, Mapping Interview, July 10, 2010). Big Momma is the queen trans-figure in Santa Fé and takes care of the other, younger trans-girls.

Map 5.21: Perceptions of Home in the 'Zona Trans'

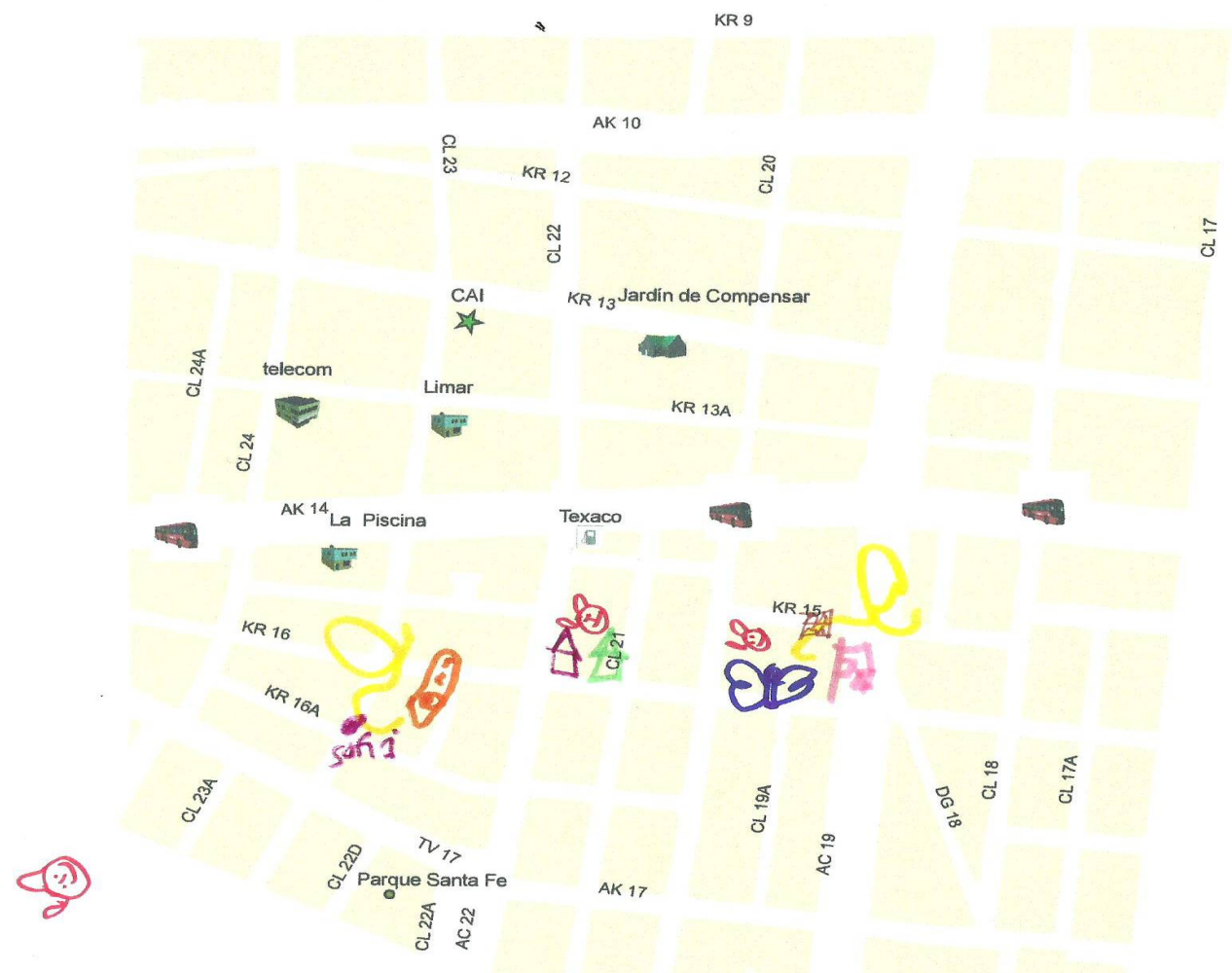




\section{Map 5.22: Transgender Subgroup - Urban Journeys through Central Bogotá}

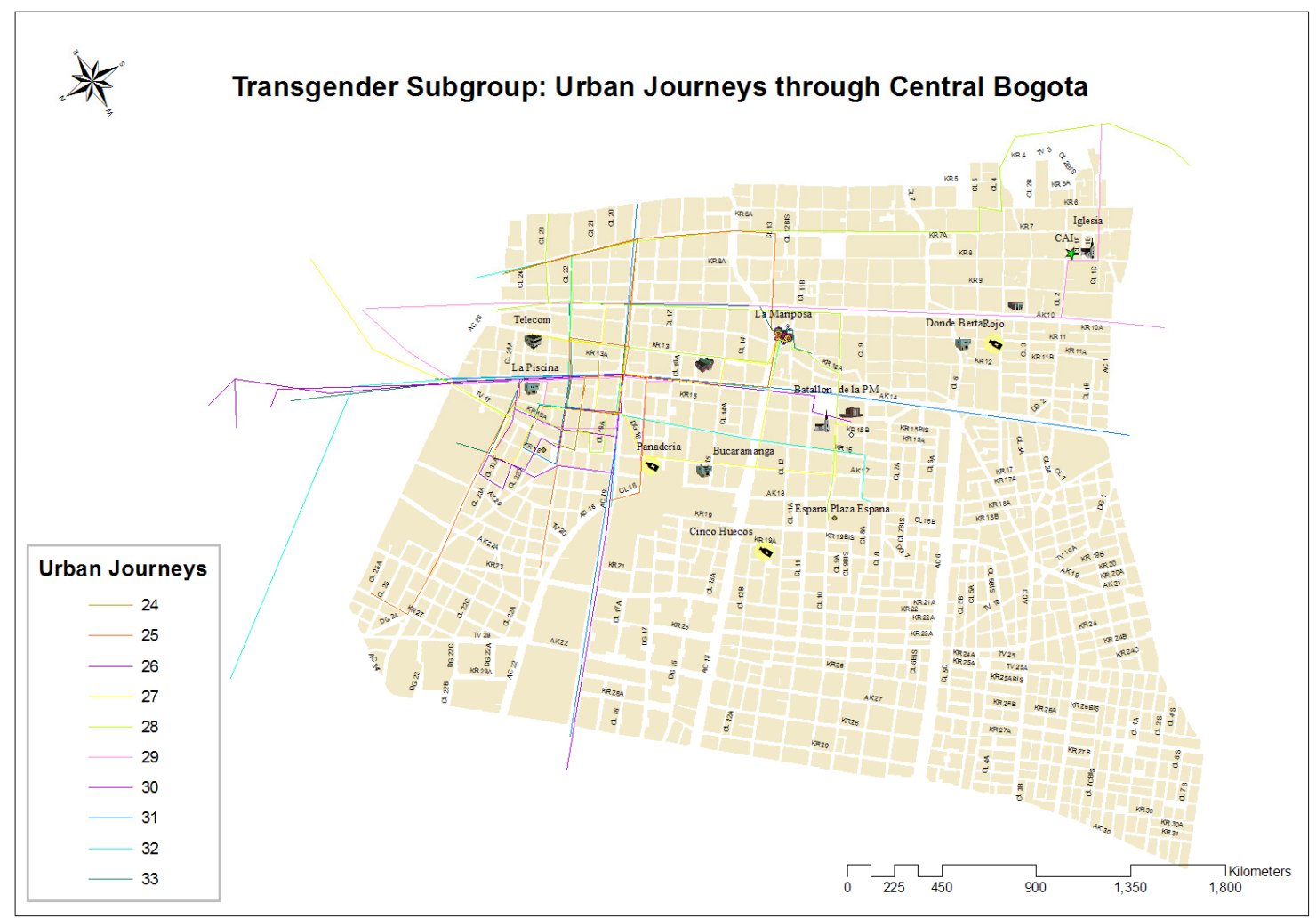

Map 5.22 visualizes the intersection and overlapping trajectories of the ten transgender research actors' urban journeys throughout central Bogotá. Five trans-girls marked spaces on the Chapinero map, four of whom marked more than one spatial variable. This is also reflected in the overlapping trajectories starting in Santa Fé and taking Caracas Avenue north towards Chapinero (refer to Map 1.2 for study site locations). Fran's general map illustrates this trend in trans-girls' journeys through the city (refer to Map 5.23). 


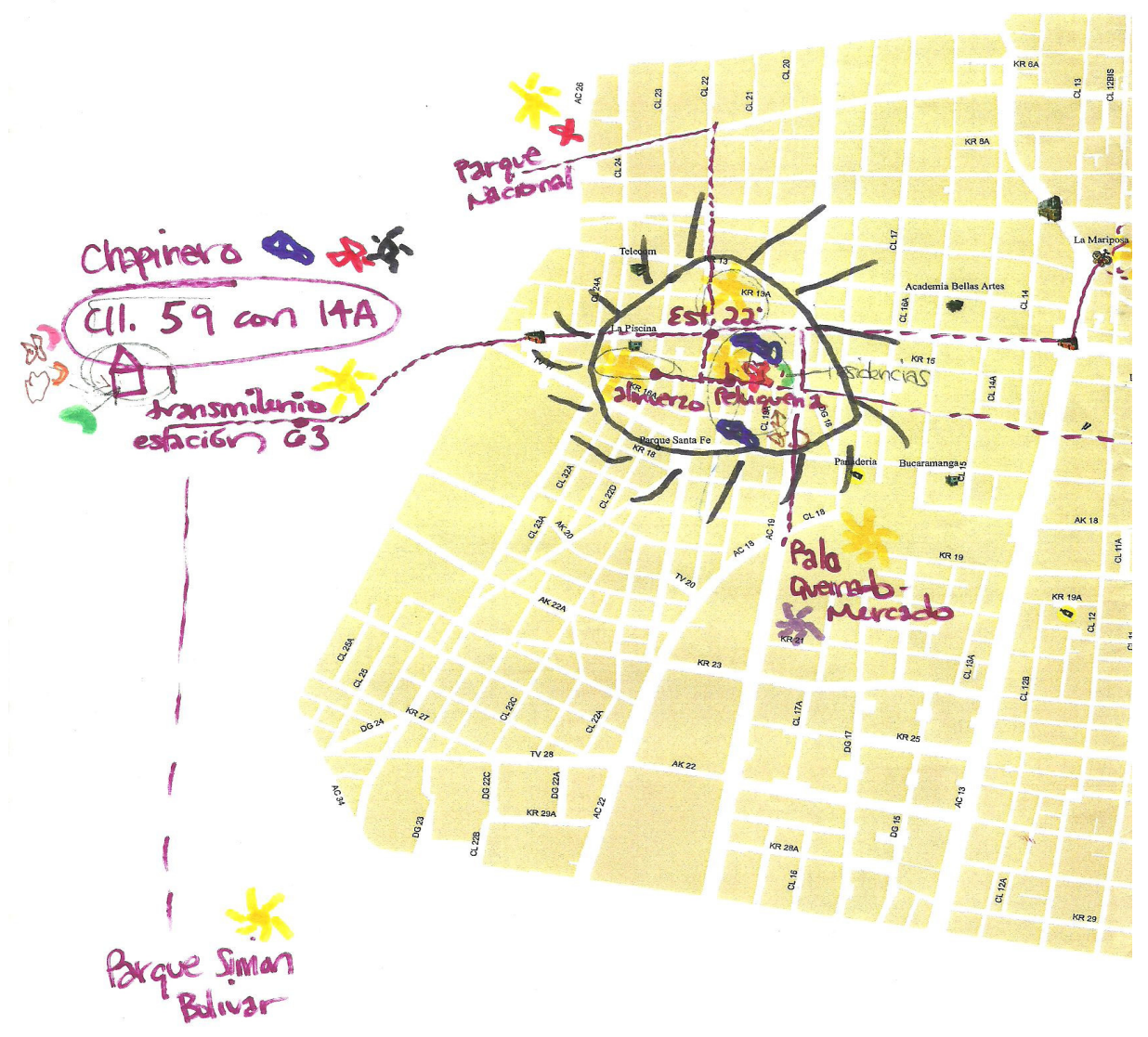

Another means of tracing street girls' urban journeys was through roving focus groups (Phase V; see chapter one). The roving focus groups also provided a perspective of how the Transgender subgroups' mobilities are limited to only three blocks of the zone of tolerance. Roving focus groups were conducted in Santa Fé with groups of 4-5 girls from each subgroup (Mariposa, Mariposa/'L,' Transgender) and the results and paths were notably different. The Transgender subgroup circled around three blocks of the city including the brothels along Caracas Avenue, the discotecas on $16^{\text {th }}$ Avenue and passing El Hueco (a drug hole) on $20^{\text {th }}$ Street. The Mariposa/' L' group, on the other hand, toured 
all of Santa Fé, entered the brothel where one of the girls in the group lived, and ended the focus group in Santa Fé's park. During the roving focus group with the Mariposa group, our path ended inside a strip joint and drinking beer with clients in two different brothels. All roving focus groups were video recorded by the girl leading each tour and are interesting to watch as they provide a live vision of the city through her eyes and the ability to take note of what places and people catch her attention.

\section{Conclusion}

Building on the descriptive text illustrating the socio-spatial reality of the five study sites in the introduction, this chapter has returned to the study sites, visualizing how the city's central areas have changed or are currently being transformed by urban improvement efforts. These transformations in urban space were illustrated through autophotographs (demonstrating what street girls see in these spaces), interview and participatory writing workshop text, lyrics from an artistic action component of the YPAR project, and through street girls' cartographic vision and perceptions of the city (as shown through their symbols and demonstrated in aggregate maps visualizing their activities and presence in each study site). This street girl vision and street corner cartography of five zones in the center of Bogotá have enabled the YPAR team to capture these places in time before the socio-spatial elements that constitute street girls' worlds in each site are lost forever through urban renewal. Street girls' voices have been prioritized and carefully represented through this dissertation. Chapter five, in particular, has enabled street girls to express their opinions about urban renewal and provide testimonies about the everyday lives and geographies of those displaced as a result of this exclusionary process purging the city of deviant people and places. 


\section{Conclusion}

Through the voices and vision of the thirty-three street girls that participated in the six- phase, eighteen-month youth-based participatory action research (YPAR) project presented in chapters one through five, this doctoral dissertation destabilizes dominant representations of Colombia in general and Bogotá in particular by introducing new actors and social dilemmas often silenced by the focus on the armed conflict and narcotrafficking. My dissertation describes the multiple methods that were collaboratively constructed and employed by the YPAR team in order to ethically and accurately enter the social and spatial worlds of street girls.

The findings suggest that doing research with marginalized youth populations requires the researcher to use vulnerable, reflexive, collaborative and participatory methodologies in order to ethically re-present street girls' lives and experiences of the 'urban everyday.' My conclusions begin with two main conceptual tools used throughout the dissertation to re-present the everyday social and spatial worlds, realities, and experiences of street girls in the city.

Through this dissertation, I have demonstrated how the integration of ethnographic and cartographic methodological approaches provides entry points into the social and spatial worlds of street girls in the city. I argue that the use of cartographic and ethnographic praxis in empowering, participatory ways enables critical children's geographers to explore the interconnection between young people's lives and urban places in Latin American cities and, in the case of my dissertation, re-present Bogotá, Colombia through marginalized young people's voices and visions of their everyday socio-spatial realities. In order to mobilize street girls' voices and visions of the city, my 
dissertation has demonstrated the importance of developing the research design within a YPAR framework in which the research process is driven by young people and research relations are derived from notions of interconnection, empathy, mutual familiarity, and social responsibility. Rather than objectifying young people as research subjects, this dissertation research places street girls at the forefront of research planning and action thus identifying them as research actors and aiming to diminish the social field traditionally fashioning hierarchies in the research process.

\section{Mobilizing the Voices and Vision of Street Girls}

In all five chapters of this dissertation, street girls' voices were woven throughout the text allowing them to re-present their diverse social and spatial experiences in the city. Beginning with study-site descriptions in chapter one drawing from participatory writing workshop and exploratory interview excerpts, street girls introduced the reader to the five official study sites by placing themselves within the social and spatial reality of the city. Through participatory writing workshops organized upon completion of the formal data collection period, research actors were directly involved in the academic writing and data analysis process enabling street girls to select excerpts for inclusion (thus textually re-presenting themselves), engage analytically with information they produced, and weave the complexity of their identities throughout the text. In chapters one, two and five, for example, street girls re-frame dominant representations of violence, displacement, secuestro (kidnappings), and desaparecidos (disappearances) as typically conceived in the broader context of Colombia. Biscocho and Blue's narratives in the introduction reveal the nuances wrapped up in conceptions of human trafficking, victimization of female youth, and kidnappings in Colombia as they express both fear of 
and indifference to drug-traffickers and campesino (farming) communities revolving around coca plant cultivation. In chapter two, El Cilencio, Sentimientos Ocultos and El Guapo's narratives present violence not in terms of the Colombian conflict and the infamous period in the $20^{\text {th }}$ century known as La Violencia but rather from their personal experiences and feelings surrounding violence in the city and how violence affects their daily lives. Additionally, conceptions of desplazamiento (displacement), as formally referring to internally displaced peoples (IDPs), and desaparecidos ('disappeared' peoples), as referring to those who are kidnapped, are challenged by narratives presented by Satanás in chapter five as she refers to forced urban displacement because of urban renewal projects (rather than displacement resulting from the armed conflict in rural areas as typically constructed in Colombia).

In order to move beyond popular conceptions of Colombia as a country characterized solely by war and drugs, I have argued for the incorporation of street girls' voices allowing other important actors to emerge and re-present their everyday lives and microgeographies within the broader context of civil strife and conflict in Colombia. An important methodological contribution, therefore, demonstrated throughout this dissertation is my suggestion to move beyond dualisms forging distance, imposing positionalities and roles, and pre-defining social relations between 'researcher' and 'participant' before they are developed in the field. I argue instead that research relations should be constructed in terms of collaboration and collective work amongst members of a research team, the cohesion and efficacy of which is based on the principle of interconnection underpinning YPAR and an ethics of care. 
I have also argued that giving a voice to the voiceless, often-cited in theory as an empowering and even emancipatory approach to overcoming the crisis of representation in the human sciences, is not enough. Research teams, therefore, need to develop mechanisms that can be operationalized in field praxis to incorporate young people as research actors not merely voices represented in academic discourse by adults. Young people should be involved in every stage of the research process, not just when the researcher determines they are needed.

As a contribution to the subfield of children's geographies, I argue that a shift must take place both in academic discourse and action in fieldwork. Incorporating youth as research actors requires us to recognize young people as not only competent researchers but, more importantly, as the driving force, the principal team members, and those most capable of guiding children's geographers through the spatial world of urban youth. I suggest that academic and human subjects protection discourse is researcherdriven thus leaving out formal considerations of collaborative research relations. The call in children's geographies to 'give a voice to young people' and give them control over the research process still implies that it is the researcher giving young people this power and privilege. In order to change this imbalanced power dynamic between adult researchers and youth participants is to change the way we see and speak with and about participants. Instead of referring to young people as participants of a research study, I suggest using the term research actor in order to diminish the social distance between each person touched by the research process and each member of the YPAR team. I also suggest that a YPAR approach creates a social space in which research actors feel comfortable interacting and collaborating in order to build a research process meaningful 
to the community (rather than driven by the academic requirements of the researcher). In addition to the principles of collective work of multiple research actors used to form the YPAR team and create research relations based on mutuality and interconnection, the polyvocality and inclusion of street girls' voices and texts in my dissertation operationalizes these key elements of YPAR in the academic writing process.

The polyvocal and intersubjective approach to knowledge construction involving the collaboration of multiple research actors is not limited to textual or ethnographic methods. As demonstrated in chapter five, re-presentations of the lives of marginalized, excluded populations are brought to life through visual methods grounded in a reflexive, participatory and multi-layered youth vision of urban space. Combining this polyvocal, intersubjective approach to knowledge construction with visual methods enabled the YPAR team to re-present the socio-spatial lives of street girls using the vision and voices of the excluded as its point of departure, rather than excluding street girls from this process of representation and knowledge production following data collection.

Through the development of participatory mapping methods, the YPAR team produced new ways of envisioning the city through cartographic and photographed representations of street girls' experience of place. By transferring cartographic power to marginalized urban youth, this grounded view of the city inverts the gaze from bird's eye to street corner, from adultist to youth, from hetero-masculinist to a multiplex-girl vision of urban space. The maps produced through feminist visualization techniques thus enable street girls to re-script and reclaim their place in the city. 


\section{The Right to the City}

In addition to placing street girls as important actors in research design and operationalization, this action component of this YPAR project placed street girls as important actors in urban planning by making them visible in institutional, academic and public spaces where they were previously invisible and voiceless. In chapter five, the YPAR team participation in urban planning seminars and other activist events in Bogotá, as well as artistic products from the Hip-Hop for Change project, demonstrates the manner in which street girls reclaimed their city on paper and in practice; through maps, photographs and textual expression of their everyday exclusion in Bogotá followed by activism to fight against the changes occurring in the city that are affecting their lives and mobility.

As substantiated through ethnographic, photographed and cartographic data presented in chapters four and five, my dissertation has illustrated the manner in which street girls' everyday geographies and social experiences of exclusion intersect with official and unofficial urban improvement efforts to clean up Bogotá by purging the city center of deviant populations and spaces.

Nine mapping categories were collaboratively selected by the YPAR team in order to collect spatial data about street girls' activity spaces and perceptions of places in the five study sites. As visualized in the cartographic images in chapter five, street girls' activity spaces clearly intersect with urban renewal projects in the center of Bogotá and exploratory, mapping, and place-perceptions interview excerpts as well as participatory writing workshop excerpts demonstrate how street girls' lives have been affected by these changes in the city. Street girls' descriptions of 'public,' 'private,' 'exclusion,' 'home' 
and other spaces demonstrate that these dichotomous categories used to make sense of urban space are insufficient when revealing street girls' complex vision of Bogotá.

Street girls' selection of auto-photographic images, especially those in chapter five, provide another window into the place-world of street girls as seen through their eyes and visually document places in the city that will be or have already been transformed or eliminated by urban renewal projects. Through the camera lens, street girls visualize the multiple meanings of urban space and bring the city to life as they see and experience it. Through the combination of visual and textual methods advanced in this dissertation, street girls identify and re-claim spaces important to them in the city. Based on this information, the YPAR team developed action-research events in order to enable street girls to assert their right to remain in those spaces and express their opinions about urban renewal projects that will permanently change the face of their central activity spaces. 


\section{BIBLIOGRAPHY}

Adams, M. and G. Moore. 2007. Participatory action research and researcher safety. In Participatory action research approaches and methods: Connecting people, participation and place, eds. Kindon, S., R. Pain, and M. Kesby, 41-48. New York: Routledge.

Aitken, Stuart C. and Joan Wingate. 1993. A Preliminary Study of the Self-Directed Photography of Middle-Class, Homeless, and Mobility-Impaired Children. The Professional Geographer 45 (1): 65-72.

Aitken, Stuart C. and Michel, S. 1995. Who contrives the "real" in GIS?: Geographic information, planning, and critical theory. Cartography and Geographic Information Systems 22 (1): 17-29.

Aitken, Stuart C. 2001. Geographies of Young People: The Morally Contested Spaces of Identity. New York: Routledge.

Aitken, Stuart C. 2002. Public Participation, Technological Discourses and the Scale of GIS. In Community Participation and Geographic Information Systems, ed. William J. Craig, Trevor M. Harris, and Daniel Weiner, 357-366. London: Taylor and Francis.

Aitken, Stuart C. 2004. Placing Children at the Heart of Globalization. In World Minds: Geographical Perspectives on 100 Problems, ed. Donald Janelle, Barney Warf and Kathy Hansen, 579-584. Norwell, MA: Kluwer Academic Publishers.

Aitken, Stuart C., Silvia L. Estrada, Joel Jennings, and Lina M. Aguirre. 2006.

Reproducing Life and Labor: Global Processes and Working Children in Tijuana, Mexico. Childhood 13 (3): 365-387.

Alderson, Priscilla.1995. Listening to Children: Children, Ethics and Social Research. London: Barnardos.

Alderson, Priscilla and Virginia Morrow. 2004. Ethics, social research and consulting with children and young people. Barkingside: Barnardos.

Alderson, Priscilla and Virginia Morrow. 2008. Ten topics for consideration in carrying out social research with children and young people. Children's Geographies 6 (1): 98-101.

Amin, Ash and Nigel Thrift. 2002. Cities and Ethnicities. Ethnicities 2 (3): 291-300.

Anderson, Jon. 2004. Talking Whilst Walking: A Geographical Archaeology of Knowledge. Area 36 (3): 254-261. 
Aptekar, Lewis. 1988. Street Children of Cali. Durham: Duke University Press.

Aptekar, Lewis. 1991. Are Colombian Street Children Neglected? The Contributions of Ethnographic and Ethnohistorical Approaches to the Study of Children. Anthropology and Education Quarterly 22 (1): 326-349.

Aptekar, Lewis. 1994. Street Children in the Developing World: A Review of Their Condition. Cross-Cultural Research 28 (3): 195-224.

Aptekar, Lewis and Paola Heinonen. 2003. Methodological Implications of Contextual Diversity in Research on Street Children. Children, Youth and Environments 13 (1). Retrieved June 5, 2006 from http://colorado.edu/journals/cye.

Beazley, Harriot. 1998. Subcultures of Resistance: Street Children's Conception and Use of Space in Indonesia. Malaysian Journal of Tropical Geography 29 (1): 11-22.

Beazley, Harriot. 2000. Street Boys in Yogyakarta: Social and Spatial Exclusion in the Public Spaces of the City. In A Companion to the City, ed. Gary Bridge and Sophie Watson, 472-488. London: Blackwell.

Beazley, Harriot. 2002. Vagrants Wearing Makeup: Negotiating Space on the Streets of Yogyakarta, Indonesia. Urban Studies 39 (9): 1665-1687.

Beazley, Harriot. 2003. The Construction and Protection of Individual and Collective Identities by Street Children and Youth in Indonesia. Children, Youth and Environments 13(1). Retrieved June 5, 2006 from http://colorado.edu/journals/cye.

Beazley, Harriot. 2004. Home Sweet Home?: Street children's Sites of Belonging. In Urban Culture: Critical Concepts in Literary and Cultural Studies, ed. Chris Jenks. London: Routledge.

Beazley, Harriot and Judith Ennew. 2006. Participatory Methods and Approaches: Tackling the Two Tyrannies. In Doing Development Research, ed. Vandana Desai and Robert Potter, 189-199. London: Sage Publications.

Beazley, Harriot. 2008. The Geographies and Identities of Street Girls in Indonesia. In Designing Modern Childhoods: History, Space, and the Material Culture of Children, ed. Marta Gutman and Ning de Coninck-Smith, 233-252. New Jersey: Rutgers University Press.

Behar, Ruth. 1996. The Vulnerable Observer: Anthropology that Breaks your Heart. Boston: Beacon Press. 
Blades, Mark, James M. Blaut, Zhra Darvizeh, Silvia Elguea, Steve Sowden, Dhiru Soni, Spencer, David Stea, Roy Surajpaul, and David Uttal. 1998. A Cross Cultural Study of Young Children's Mapping Abilities. Transactions of the Institute of British Geographers 23 (2): 269-277.

Blaut, James M. 1991. Natural Mapping. Transactions of the Institute of British Geographers 16 (1): 55-74.

Blaut, James M. 1997a. The Mapping Abilities of Young Children: Children Can. Annals of the Association of American Geographers 87 (1): 152-158.

Blaut, James M. 1997b. Piagetian Pessimism and the Mapping Abilities of Young Children: A Rejoinder to Liben and Downs. Annals of the Association of American Geographers 87 (1): 168-177.

Blunt, Alison and Robyn Dowling. 2006. Home. London: Routledge.

Bromling, Clifflyn M. 1997. Images of Street Children: A Study on Naming and Framing a Social Problem at UNICEF Brazil, Headquarters and Egypt. Ph.D. diss., Harvard University.

Bunge, William and R. Bordessa. 1975. The Canadian Alternative: Survival, Expeditions, and Urban Change. Toronto: York University.

Butz, David. 2008. Sidelined by the guidelines: Reflections on the limitations of standard informed consent procedures for the conduct of ethical research. ACME: An International E-Journal for Critical Geographies 7(2): 239-59, available online at http://www.acme-journal.org/vol7/DBu.pdf, accessed October 2009.

Burawoy, Michael, Joseph Blum, S. George, Z. Gille, T. Gowan, L. Haney, M. Klawiter, S. Lopez, S. O'Riain, and M. Thayer. 2000. Global ethnography: Forces, connections and imaginations in a postmodern world. Berkeley: University of California Press.

Cahill, Caitlin. 2000. Street literacy: urban teenagers' strategies for negotiating their neighborhood. Journal of Youth Studies 3(3): 251-278.

Cahill, Caitlin and M.E. Torre. 2007. Beyond the journal article: Representations, audience, and the presentation of participatory research. In Sara Kindon, Rachel Pain and Mike Kesby (Eds.) Participatory Action Research Approaches and Methods: Connecting People, Participation and Place. New York: Routledge. 
Cahill, Caitlin, F. Sultana, and R. Pain. 2007. Participatory ethics: Politics, practices, institutions. ACME: An International E-Journal for Critical Geographies 6(3): 304-18, available online at http://www.acme-journal.org/Volume6-3.htm, accessed October 2009.

Cahill, Caitlin. 2007a. Doing Research with Young People: Participatory Research and the Rituals of Collective Work. Children's Geographies 5(3): 297-312.

Cahill, Caitlin. 2007b. The personal is political: Developing new subjectivities in a participatory action research process. Gender, Place, and Culture 14 (3): 267-292.

Cahill, C., M. Bradley, D. Castañeda, L. Esquivel, N. Mohamed, J. Organista, J. Sandberg, M. Valerio, and K. Winston. 2008a. "Represent": Reframing risk through participatory video research. In Downing, M. and Tenney, L. eds. Video Vision: Changing the Culture of Social Science Research. Cambridge Scholars Publishing.

Cahill, C., I. Rios-Moore and T. Threatts. 2008b. Different Eyes / Open Eyes: Community-Based Participatory Action Research. In Cammarota, J. and Fine. M. eds. Revolutionizing Education: Youth Participatory Action Research in Motion. New York: Routledge.

Cámara de Comercio de Bogotá. 1997. Habitantes de la Calle: Un Estudio Sobre El Cartucho en Santa Fe de Bogotá. Bogotá: Departamento de Publicaciónes, Cámara de Comercio de Bogotá.

Campos, Regina, Marcela Raffaelli, Walter Ude, Marilia Greco, Andrea Ruff, Jon Rolf, Carlos M. Antunes, Neal Halsey and Dirceu Greco (Street Youth Study Group). 1994. Social Networks and Daily Activities of Street Youth in Belo Horizonte, Brazil. Child Development 65 (2): 319-330.

Carvajal, Juan Carlos. 2005. Territorio y Cartografia Social: Fortalecimiento de las Organizaciones pertenecientes a la Asociación de Proyectos Comunitarios. Popayán: Asociación de Proyectos Comunitarios.

Christensen, Pia and Margaret O'Brien. 2003. Children in the City: Home, Neighbourhood and Community. New York: Routledge.

Christensen, Pia. 2004. Children's Participation in Ethnographic Research: Issues of Power and Representation. Children and Society 18: 165-176.

Christensen, Pia and Alan Prout. 2002. Working with Ethical Symmetry in Social research with Children. Childhood 9 (4): 477-497. 
Cloke, Paul. 2002. Deliver us from evil? Prospects for living ethically and acting politically in human geography. Progress in Human Geography 26(5): 587-604.

Connolly, Mark and Judith Ennew. 1996. Introduction: Children Out of Place. Childhood 3 (2): 131-145.

Conradson, David. 2003. Geographies of care: spaces, practices and experiences. Social and Cultural Geography 4(4): 451 - 454.

Cope, Meghan. 1996. Weaving the Everyday: Identity, Space and Power in Lawrence, Massachusetts, 1920-1939. Urban Geography 17(2): 179-204.

Cope, Meghan. 2008. Patchwork Neighborhood: Children's Real and Imagined Geographies in Buffalo, NY. Environment and Planning A 40: 2845-2863.

Cope, Meghan. 2009. Challenging Adult Perspectives on Children's Geographies and Participatory Research: Insights from a Service-Learning Course. Journal of Geography in Higher Education 33(1): 33-50.

Cope, Meghan and Sarah Elwood. eds. 2009. Qualitative GIS: A Mixed-methods Approach. London: Sage.

Crang, Mike. 2002. Qualitative methods: the new orthodoxy? Progress in Human Geography 26 (5): 647-655.

Crang, Mike. 2003. Qualitative methods: touchy, feely, look-see? Progress in Human Geography 27 (4): 494-504.

Crang, Mike. 2005. Qualitative methods: there is nothing outside the text? Progress in Human Geography. 29 (2): 225-233.

Crang, Mike and Ian Cook. 2007. Doing Ethnographies. Thousand Oaks: Sage Publications.

Craig, W.J., T.M. Harris and D. Weiner. 2002. Introduction. In Craig, W.J., Harris, T.M., and Weiner, D. eds. Community Participation and Geographic Information Systems. London: Taylor and Francis, 1-16.

Cresswell, Tim. 1996. In Place/Out of Place: Geography, Ideology and Transgression. Minneapolis: University of Minnesota Press.

Cresswell, Tim. 1997. Weeds, Plagues, and Bodily Secretions: A Geographical Interpretation of Metaphors of Displacement. Annals of the Association of American Geographers 87 (2): 330-345. 
Cresswell, Tim. 1998. Night Discourse: Producing Consuming Meaning on the Street. In Nick Fyfe ed. Images of the Street: Planning, Identity and Control in Public Space. New York: Routledge.

Cresswell, Tim. 1999. Embodiment, Power and the Politics of Mobility: The Case of Female Tramps and Hobos. Transactions of the Institute of British Geographers 24 (2): 175-192.

Cresswell, Tim. 2001. The Production of Mobilities. New Formations 43: 11-25.

Cresswell, Tim. 2010. Towards a Politics of Mobility. Environment and Planning D: Society and Space 28 (1): $17-31$.

De Pineda, Virginia G., Elvia I. de Munoz, Patricia V. De Pineda, Yolanda Echeverry and Jairo Arias. 1978. El Gamin: Su Albergue social y su familia.. Bogotá: Instituto Colombiano de Bienestar Familiar.

Doucet, Andrea and Natasha Mauthner. 2002. Knowing Responsibly: Linking Ethics, Research Practice and Epistemology. In Ethics in Qualitative Research, eds. Melanie Mauthner, Maxine Birch, Julie Jessop and Tina Miller. London: Sage Publications.

Duncombe, Jean and Julie Jessop. 2002. 'Doing Rapport' and the Ethics of 'Faking Friendship'. In Ethics in Qualitative Research, eds. Melanie Mauthner, Maxine Birch, Julie Jessop and Tina Miller. London: Sage Publications.

Douglas, Mary. 1966. Purity and Danger. New York: Routledge.

Elwood, Sarah. 2006. Critical Issues in Participatory GIS: Deconstructions, Reconstructions, and New Research Directions. Transactions in GIS 10(5): 693708 .

Emerson, Robert, Rachel Fretz and Linda Shaw. 1995. Writing Ethnographic Fieldnotes. Chicago: University of Chicago Press.

Ennew, Judith. 1994. Street and Working Children: A Guide to Planning (Development Manual 4). London: Save the Children.

Ennew, Judith and Jill Swart-Kruger. 2003. Introduction: Homes, Places and Spaces in the Construction of Street Children and Street Youth. Children, Youth and Environments 13 (1). Retrieved June 5, 2006 from http://colorado.edu/journals/cye. 
Evans, Ruth. 2006. Negotiating Social Identities: The Influence of Gender, Age and Ethnicity on Young People's 'Street Careers' in Tanzania. Children's Geographies 4 (1): 109-128.

Evans, James and Phil Jones. 2011. The walking interview: Methodology, mobility and place. Applied Geography 31 (2): 849-858.

Felsman, Kirk. 1981. Street Urchins of Cali: On Risk, Resiliency and Adaptation in Childhood. PhD diss., Harvard University.

Foucault, Michel. 1972. The Archaeology of Knowledge and the Discourse on Language. New York: Pantheon Books.

Furth, Gregg M. 1988. The Secret World of Drawings: Healing Through Art. Boston: Sigo Press.

Fyfe, Nicholas, ed. 1998. Images of the Street: Planning, Identity and Control in Public Space. New York: Routledge.

Geertz, Clifford. 1973. Thick Description: Toward an Interpretive Theory of Culture. In The Interpretation of Cultures: Selected Essays, 3-30. New York: Basic Books.

Gilbert, Melissa and Michele Masucci. 2006. The Implications of Including Women's Daily Lives in a Feminist GIScience. Transactions in GIS 10 (5): 751-761.

Glauser, Benno. 1997. Street Children: Deconstructing a Construct. In Constructing and Reconstructing Childhood: Contemporary Issues in the Sociological Study of Childhood, eds. Allison James and Alan Prout. Washington: Falmer Press.

Golledge, Reginald and Robert Stimson. 1987. Analytical Behavioural Geography. London: Croom Helm.

Gough, Katherine and Monica Franch. 2005. Spaces of the Street: Socio-spatial Mobility and Exclusion of Youth in Recife. Children's Geographies 3 (2): 149-166.

Gillis, J. R. 2008. The islanding of children - Reshaping the mythical landscapes of childhood. In Designing modern childhoods: History, space, and the material culture of children, eds. Gutman, M. and N. Coninck-Smith, 316-330. New Jersey: Rutgers University Press.

Gould, Peter. 1975. People in Information Space: The Mental Maps of Information Surfaces of Sweden. The Royal University of Lund.

Gould, Peter and Rodney White. 1992. Mental Maps. New York: Routledge. 
Guerrero, Sandra Mateus. 1995. Limpieza Social: Guerra Contra La Indigencia. Coleccion de Colombia Hoy. Bogotá: Editorial Presencia Ltda.

Gilbert, Melissa and Michele Masucci. 2006. The Implications of Including Women's Daily Lives in a Feminist GIScience. Transactions in GIS 10 (5): 751-761.

Guzmán, Germán C.1968. La Violencia en Colombia: Parte Descriptiva. Cali: Ediciones Progreso.

Hanson, Susan. 2002. Connections. Gender, Place and Culture 9 (3): 301-303.

Hecht, Tobias. 1998. At Home in the Street: Street Children of Northeast Brazil. Cambridge: Cambridge University Press.

Hecht, Tobias. 2001. In Search of Brazil's Street Children. In Abandoned Children, ed. Catherine Panter-Brick and Malcom Smith, 146-160. Cambridge: Cambridge University Press.

Holloway, Sarah L. and Gill Valentine. 2000a. Spatiality and the New Social Studies of Childhood. Sociology 34: 763-783.

Holloway, Sarah L. and Gill Valentine, eds. 2000b. Children's Geographies: Playing Living, Learning. London: Routledge.

Holt, Louise. 2004. The 'Voices' of Children: De-centring Empowering Research Relations. Children's Geographies 2 (1): 13-27.

Hopkins, Peter. 2008. Ethical issues in research with unaccompanied asylum-seeking children. Children's Geographies 6 (1): 37-48.

HRW (Human Rights Watch). 1994. Generation Under Fire: Children and Violence in Colombia. New York: Human Rights Watch/Americas.

Inciardi, James. 1993. Kingrats, Chicken Heads, Slow Necks, Freaks, and Blood Suckers: A Glimpse at the Miami Sex-for-Crack Market in Ratner, Mitchell S. ed. Crack Pipe as Pimp: An Ethnographic Investigation of Sex-for-Crack Exchanges. New York: Lexington Books.

Inter-American Commission on Human Rights (IACHR).1999. Third Report on the Human Rights Situation in Colombia: Chapter XIII on 'The Rights of the Child'. Retrieved on August 9, 2008 from http://www.cidh.org/countryrep/Colom99en/table\%20of\%20contents.htm 
Inwood, Joshua and Deborah Martin. 2008. Whitewash: White Privilege and Racialized Landscapes at the University of Georgia. Social and Cultural Geography 9(4): 373-395.

Jacobs, Jane. 1961. The Death and Life of Great American Cities. New York: Random House.

James, Allison, Chris Jenks and Alan Prout. 1998. Theorizing Childhood. Cambridge: Polity.

James, Allison and Alan Prout. 1997. Constructing and Reconstructing Childhood: Contemporary Issues in the Sociological Study of Childhood. Washington: Falmer Press.

Katz, Cindi. 2004. Growing Up Global: Economic Restructuring and Children's Everyday Lives. Minneapolis: University of Minnesota Press.

Kesby, Mike. 2007. Methodological Insights on and from Children's Geographies. Children's Geographies 5 (3): 193-205.

Kesby, Mike, Fungisai Gwanzura-Ottemoller, and Monica Chizororo. 2006. Theorising other, 'other childhoods': Issues Emerging from Work on HIV in Urban and Rural Zimbabwe. Children's Geographies 4 (2): 185-202.

Knigge, LaDona and Meghan Cope 2009. Grounded Visualization and Scale: A Recursive Analysis of Community Spaces. In Meghan Cope and Sarah Elwood (eds.) Qualitative GIS: A Mixed Methods Approach. London: Sage, pp. 95-114.

Kristeva, Julia. 1982. Powers of Horror. New York: Columbia University Press.

Kwan, Mei-Po. 2002a. Feminist Visualization: Re-envisioning GIS as a Method in Feminist Geographic Research. Annals of the Association of American Geographers 92 (4): 645-661.

Kwan, Mei-Po. 2002b. Is GIS for Women? Reflections on the Critical Discourse in the 1990s. Gender, Place and Culture 9 (3): 271-279.

Kwan, Mei-Po and LaDona Knigge. 2006. Doing qualitative research using GIS: An oxymoronic endeavor? Environment and Planning A 38(11): 1999-2002.

Lalor, Kevin. 1999. Street Children: A Comparative Perspective. Child Abuse and Neglect 23 (8): 759-770.

Langevang, Thilde. 2007. Movements in Time and Space: Using Multiple Methods in Research With Young People in Accra, Ghana. Children's Geographies 5 (3): 267-282. 
Lawson, Victoria. 2007. Geographies of care and responsibility. Annals of the Association of American Geographers 97(1): 1-11.

Liggett, Helen. 2003. Urban Encounters. Minneapolis: University of Minnesota Press.

Low, Setha. 2000. On the Plaza: the Politics of Public Space and Culture. Austin: University of Texas Press.

Low, Setha, ed. 2005. Theorizing the City: The New Urban Anthropology Reader. New Jersey: Rutgers University Press.

Lusk, Mark W. 1992. Street Children of Rio de Janeiro. International Social Work 35 (3): 293-305.

Lyng, Stephen. 1998. Dangerous methods: Risk taking and the Research Process, in Ferrell, Jeff and Hamm, Mark S. eds. Ethnography at the Edge: Crime, Deviance and Field Research. Boston: Northeastern University Press.

Lynch, Kevin. 1960. The Image of the City. Cambridge: The M.I.T. Press.

Malchiodi, Cathy A. 1997. Breaking the Silence: Art Therapy with Children from Violent Homes. Levittown, PA: Brunner/Mazel.

Martin, D.G. 2007. Bureaucratizing ethics: Institutional Review Boards and participatory research. ACME: An International E-Journal for Critical Geographies 6(3): 319328, available online at http://www.acme-journal.org/Volume6-3.htm, accessed October 2009.

Massey, Doreen. 1998. The Spatial Construction of Youth Cultures. In Cool Places: Geographies of Youth Cultures, ed. Tracey Skelton and Gill Valentine, 121-129. New York: Routledge.

Massey, Doreen. 2005. For Space. London: Sage Publications.

Matthews, Hugh. 1995. Culture, environmental experience and environmental awareness: making sense of young Kenyan children's views of place. The Geographical Journal 161 (3): 285-295.

Matthews, Hugh, Melanie Limb and Mark Taylor. 1998. The Geography of Children: Some Ethical and Methodological Considerations for Project and Dissertation work. Journal of Geography in Higher Education 22(3): 311 - 324.

Matthews, Hugh and Melanie Limb. 1999. Defining an Agenda for the Geography of Children: Review and Prospect. Progress in Human Geography 23 (1): 61-90. 
Matthews, Hugh. 2003. The street as a liminal space: the barbed spaces of childhood. In Children in the City: Home, neighborhood and community, ed. Pia Christensen and Margaret O'Brien. New York: Routledge Falmer.

Matthews, Stephen, James Detwiler, and Linda Burton. 2005. Geo-ethnography: Coupling Geographic Information Analysis Techniques with Ethnographic Methods in Urban Research. Cartographica 40 (4): 75-90.

McLafferty, Sara. 1995. Counting for Women. The Professional Geographer 47: 436442.

McLafferty, Sara. 2002. Mapping Women's Worlds: Knowledge, Power and the Bounds of GIS. Gender, Place and Culture 9 (3): 263-269.

Melo, Jorge. 1998. The Drug Trade, Politics and the Economy: The Colombian Experience. In Latin America and the Multinational Drug Trade, eds. Elizabeth Joyce and Carlos Malamud. London: Institute of Latin American Studies.

Miller, William.1991. Motivational Interviewing: Preparing People to Change Addictive Behavior. Guilford: New York.

Mitchell, Don. 1996. Introduction: Public Space and the City. Urban Geography 17(2): $127-131$.

Mitchell, Don. 2003. The Right to the City: Social Justice and the Fight for Public Space. New York: The Guilford Press.

Morrow, Virginia. 2008. Ethical dilemmas in research with children and young people about their social environments. Children's Geographies 6 (1): 49-61.

Morrow, Virginia and Martin Richards. 1996. The Ethics of Social Research with Children: An Overview. Children and Society 10: 90-105.

Motzafi-Haller, Pnina. 1997. Writing birthright: On Native Anthropologists and the Politics of Representation. In Auto/ethnography: rewriting the self and the social, ed. D. Reed Danahay. Oxford: Berg.

Narayan, Kirin. 1993. How Native is a 'Native Anthropologist? American Anthropologist 95 (3): 671-86.

Niño, Soledad; Lugo, Nelsom; Rozo, Cesar \& Vega, Leonardo A. 1998. Territorios del Miedo en Santafe de Bogota: Imaginarios de los ciudadanos (Territories of Fear in Santa Fé of Bogotá: Citizen's Imaginaries). Bogota: TM Editores.

Obermeyer, N.J. 1998. The Evolution of Public Participation GIS. Cartography and Geographic Information Systems 22: 90-97. 
Oguist, Paul. 1978. Violencia, Conflicto and Politica en Colombia. (printed in conjunction with Instituto de Estudios Colombianos). Bogotá: Talleres Graficos Banco Popular.

Ormsby, Tim, Napoleon, Eileen, Burke, Robert, and Carolyn Groessl. 2008. Getting to Know ArcGIS Desktop: Basics of ArcView, ArcEditor, and ArcInfo. Second Edition. Redlands, California: ESRI Press.

O’Sullivan, David. 2006. Geographic Information Science: Critical GIS. Progress in Human Geography 30(6): 783-791.

Panelli, Ruth, Samantha Punch and Elsbeth Robson, eds. 2007. Global Perspectives on Rural Childhood and Youth: Young Rural Lives. London: Routledge.

Panter-Brick, Catherine. 2004. Homelessness, Poverty, and Risks to Health: Beyond at Risk Categorizations of Street Children. Children's Geographies 2 (1): 83-94.

Pavlovskaya, Marianna. 2002. Mapping Urban Change and Changing GIS: Other Views of Economic Restructuring. Gender, Place and Culture 9 (3): 281-289.

Pavlovskaya, Marianna. 2006. Theorizing with GIS: A tool for critical geographies? Environment and Planning A 38 (11): 2003-2020.

Pavlovskaya, Marianna and Kevin St. Martin. 2007. Feminism and Geographic Information Systems: From a Missing Object to a Mapping Subject. Geography Compass 1(3): 583-606.

Payne, James. 1968. Patterns of Conflict in Colombia. New Haven: Yale University Press.

Pile, Steve. 1996. The Body and the City: Psychoanalysis, Space and Subjectivity. New York: Routledge.

Pile, Steve. 2010. Emotions and affect in recent human geography. Transactions of the Institute of British Geographers 35: 5-20.

Pocock, Douglas and Ray Hudson. 1978. Images of the Urban Environment. New York: Columbia University Press.

Popke, Jeffrey. 2006. Geography and ethics: Everyday mediations through care and consumption. Progress in Human Geography 30(4): 504-512.

Portes, Alejandro. 1972. Rationality in the Slum: An Essay on Interpretive Sociology. Comparative Studies in Society and History 14 (3): 268 - 286. 
Pred, Allan. 2004. The Past is not Dead: Facts, Fictions, and Enduring Racial Stereotypes. Minneapolis: University of Minnesota Press.

Punch, Samantha. 2002. Research with Children: The Same or Different from Research with Adults? Childhood 9 (3): 321-341.

Punch, Samantha. 2003. Childhoods in the Majority World: Miniature Adults or Tribal Children? Sociology 37 (2): 277-295.

Raffaelli, Marcela. 1997. The Family Situation of Street Youth in Latin America: A Cross-National Review. International Social Work 40: 89-100.

Reyes, Alejandro. 1994. Drug Trafficking and the Guerilla Movement in Colombia. In Drug Trafficking in the Americas, eds. Bruce Bagley and William Walker III. New Brunswick: Transaction Publishers.

Ritterbusch, Amy. 2012 (forthcoming). Bridging Guidelines and Practice: Towards a Grounded Care Ethics in Youth Participatory Action Research. The Professional Geographer.

Rizzini, Irene. 1996. Street Children: An Excluded Generation in Latin America. Childhood 3 (2): 215-233.

Rizzini, Irene, Irma Rizzini, Monica Munoz-Vargas and Lidia Galeano. 1994. Brazil: A New Concept of Childhood. In Urban Children in Distress: Global Predicaments and Innovative Strategies, ed. Cristina Szanton Blanc, 55-100. Florence: UNICEF/International Child Development Centre.

Robbins, Arthur. 1994. A Multi-Modal Approach to Creative Art Therapy. Philadelphia: Jessica Kingsley Publishers.

Robinson, Fiona. 1999. Globalizing Care: Ethics, Feminist Theory and International Relations. Boulder, CO: Westview Press.

Rogers, Tim. 2008. Postcard: Managua. Time. Retrieved January 24, 2011 from http://www.time.com/time/magazine/article/0,9171,1704681,00.html.

Ross, Timothy. 2002a. Displacement and Risk in Colombia: Young People Selling Sex in the Streets of Bogotá. Research for Sex Work 5 (June), Retrieved October 4, 2007 from http://hcc.med.vu.nl/artikelen/ross.htm.

Ross, Timothy. 2002b. Using and Dealing on Calle 19: A High Risk Street Community in Central Bogotá. International Journal of Drug Policy 13: 45-56. 
Ross, Timothy. 2006. Entre Quimeras y Dilemas: Los niños se vuelvan objeto sexual. Actualidad Colombiana 436 (Agosto [August] 28), Retrieved November 21, 2007 from http://www.actualidadcolombiana.org.

Routledge, Paul. 2003. Convergence space: Process geographies of grassroots globalization networks. Transactions of the Institute of British Geographers 28: 333-349.

Sharp, Joanne. 2005. Geography and Gender: Feminist Methodologies in Collaboration and in the Field. Progress in Human Geography 29(3): 304-309.

Scheper-Hughes, Nancy. 1992. Death Without Weeping: The Violence of Everyday Life in Brazil. Berkeley: University of California Press.

Scheper-Hughes, Nancy and Daniel Hoffman. 1994. Kids Out of Place: Street Children of Brazil. Special Issue on Disposable Children: The Hazards of Growing Up in Latin America. NACLA 27 (6): 16-23.

Scheper-Hughes, Nancy and Daniel Hoffman. 1998. Brazilian Apartheid: Street Kids and the Struggle for Urban Space. In Small Wars: The Cultural Politics of Childhood, ed. Nancy Scheper-Hughes and Carolyn Sargent, 352-388. Berkeley: University of California Press.

Schuurman, Nadine and Geraldine Pratt. 2002. Care of the Subject: feminism and critiques of GIS. Gender, Place and Culture 9 (3): 291-299.

Sibley, David. 1995a. Geographies of Exclusion: Society and Difference in the West. New York: Routledge.

Sibley, David. 1995b. Families and domestic routines: constructing the boundaries of childhood. In Mapping the Subject: Geographies of Cultural Transformation, ed. Steve Pile and Nigel Thrift. London: Routledge.

Sime, Daniela. 2008. Ethical and methodological issues in engaging young people living in poverty with participatory research methods. Children's Geographies 6 (1): 64 78.

Skelton, Tracey and Gill Valentine. 1998. Cool Places: Geographies of Youth Cultures. New York: Routledge.

Skelton, Tracey. 2008. Research with children and young people: exploring the tensions between ethics, competence and participation. Children's Geographies 6 (1): 2136. 
Smith, D.M. 1998. How far should we care? On the spatial scope of beneficence. Progress in Human Geography 22: 15-38.

Téllez, Marcos Granados. 1976. Gamines. Bogotá: Editorial Temis.

Taussig, Michael. 2003. La ley en una Tierra sin Ley: Diario de una Limpieza. In Fronteras de la Modernidad en America Latina. Pittsburgh: Instituto Internacional de Literatura Iberoamericana.

Thomas, Nigel and O'Kane, Claire. 1998. The Ethics of Participatory Research with Children. Children and Society 12: 336-348.

Thoumi, Francisco E. 1994. The Size of the Illegal Drug Industry. In Drug Trafficking in the Americas, eds. Bruce Bagley and William Walker III. New Brunswick: Transaction Publishers.

Thoumi, Francisco E. 1995. Political Economy and Illegal Drugs in Colombia: Studies on the Impact of the Illegal Drug Trade. Volume 2. Boulder, CO: Lynne Rienner Publishers.

Thomson, Fionagh. 2007. Are Methodologies for Children keeping them in their Place? Children's Geographies 5 (3): 207-218.

Thrift, Nigel. 2000. Dead or alive? In Cook, I., Crouch, D., Naylor, S. and Ryan, J. eds, Cultural Turns/Geographical Turns. Harlow: Prentice Hall.

Tuhiwai Smith, Linda. 1999. Decolonizing Methodologies: Research and Indigenous Peoples. New York: Zed Books.

United Nations Development Programme (UNDP). 2007. Human Development Report. New York: UNDP. Retrieved January 3, 2008 from http://hdr.undp.org/en/media/hdr 20072008 en complete.pdf.

U.S. State Department .2001. Country Report on Human Rights Practices: Colombia. Retrieved August 7, 2008 from http://www.state.gov/g/drl/rls/hrrpt/2001/wha/8326.htm

Valentine, Gill. 1996. Children Should Be Seen and Not Heard: the Production and Transgression of Adults' Public Space. Urban Geography 17: 173-188.

Valentine, Gill. 2004. Public Space and the Culture of Childhood. Burlington, VT: Ashgate.

Van Beers, Henk. 1996. A Plea for a Child-Centred Approach in Research with Street Children. Childhood 3 (2): 195-201. 
Van Blerk, Lorraine. 2005. Negotiating Spatial Identities: Mobile Perspectives on Street Life in Uganda. Children's Geographies 3 (1): 5-21.

Van Blerk, Lorraine and Nicola Ansell. 2007. Participatory Feedback and Dissemination with and for Children: Reflections from Research with Young Migrants in Southern Africa. Children's Geographies 5 (3): 313-324.

Vanderbeck, Robert and Cheryl Morse Dunkley. 2004. Introduction: Geographies of Exclusion, Inclusion and Belonging in Young Lives. Children's Geographies 2 (2): $177-183$.

Walmsley, D.J. 1988. Urban Living: The Individual in the City. New York: Longman Scientific and Technical.

Ward, Colin. 1978. The Child in the City. New York: Pantheon Books.

Williams, Morris, Owain Jones, Lucy Wood, and Constance Fleuriot. 2006. Investigating New Wireless Technologies and Their Potential Impact on Children's Spatiality: A Role for GIS. Transactions in GIS 10 (1): 87-102.

Williamson, Emma, Trudy Goodenough, Julie Kent, and Richard Ashcroft. 2005. Conducting Research with Children: The Limits of Confidentiality and Child Protection Protocols. Children and Society 19: 397-409.

Winton, Ailsa. 2005. Youth, Gangs and Violence: Analysing the Social and Spatial Mobility of Young People in Guatemala City. Children's Geographies 3 (2): 167184.

Wolf, Diane. 1996. Situating Feminist Dilemmas in Fieldwork. In Feminist Dilemmas in Fieldwork, ed. Diane Wolf, 1-55. Boulder: Westview.

Wright, James D., Martha Wittig and Donald Kaminsky. 1993. Street Children in North and Latin America: Preliminary Data from Proyecto Alternativos in Tegucigalpa and Some Comparisons with the U.S. Case. Studies in Comparative International Development 28 (2): 81-92.

Wright, Melissa. 2004. From Protests to Politics: Sex Work, Women's Worth, and Ciudad Juarez Modernity. Annals of the Association of American Geographers 94 (2): 369-386.

Young, Lorraine and Barrett, Hazel. 2001. Issues of Access and Identity: Adapting Research Methods with Kampala Street Children. Childhood 8 (3): 383-395. 
VITA

AMY E. RITTERBUSCH

2008-2011

2005-2006
Ph.D. Candidate, International Relations, Florida International University, Miami, Florida.

American Association of University Women Dissertation Fellowship.

National Science Foundation Doctoral Dissertation Research Improvement Grant. Co-funded by the NSF Geography and Spatial Sciences Program and the NSF Office of International Science and Engineering.

Fulbright U.S. Student Program. Funded to conduct doctoral dissertation research project entitled, 'The Geographies of Street Girls in Bogotá, Colombia'.

Doctoral Evidence Acquisition Fellowship. University Graduate School. Florida International University.

M.A., International Studies, Florida International University, Miami, Florida. 2008, December.

Funded as Research Assistant by the National Science Foundation, Human and Social Dynamic Crosscutting Program, Agents of Change Subsection. "Comparative Civic and Place Engagement in Three Latino Enclave Neighborhoods in Transition". Principal Investigators: Damian Fernandez (FIU) and Patricia Price (FIU).

B.A., International Studies, West Virginia University, Morgantown. 2005, May. 
B.A., Foreign Languages (Spanish), West Virginia University, Morgantown. 2005, May.

\section{PUBLICATIONS AND PRESENTATIONS}

Ritterbusch, Amy. 2012. Bridging Guidelines and Practice: Towards a Grounded Care Ethics in Youth Participatory Action Research. The Professional Geographer.

Ritterbusch, Amy. 2008. Review of Global Perspectives on Rural Childhood and Youth: Young Rural Lives, ed. Ruth Panelli, Samantha Punch, and Elsbeth Robson. London: Routledge, 2007. Children's Geographies 6(2): 219-222.

2010, November 17: Keynote address. International Education Week: Fulbright Colombia, Education USA and the U.S. Embassy (Sponsored by the State Department and the U.S. Department of Education). Bogotá, Colombia. Reframing 'Empowerment' in Participatory Action Research with Marginalized Urban Youth: From Research Subject to Research Actor.

2010, May 28: Conference of Latin Americanist Geographers (CLAG). Universidad de los Andes, Bogotá, Colombia. Doing Research with Street Girls: Towards a Grounded Care Ethics in Participatory Action Research (PAR).

2009, June 11: Latin American Studies Association Annual Congress (LASA). Rio de Janeiro, Brazil. The Geographies of Street Girls in Bogotá, Colombia: A MultiMethod Approach to Conducting Research with Street Children.

2009, March 22: Annual Meeting of the Association of American Geographers (AAG). Las Vegas, NV. Doing Research with Street Children: The Ethics of Participatory Research and Representation. 